\title{
AN EVALUATION AND SUMMARY OF A STUDY OF THE LONG-TERM MULTIAXIAL CREEP BEHAVIOR OF CONCRETE
}

By Thomas W. Kennedy

RESEARCH REPORT $3899-2$

to

OAK RIDGE NATIONAL LABORATORY operated by UNION CARBIDE CORPORATION for U.S. ENERGY RESEARCH AND DEVELOPMENT ADMINISTRATION 


\section{DISCLAIMER}

This report was prepared as an account of work sponsored by an agency of the United States Government. Neither the United States Government nor any agency Thereof, nor any of their employees, makes any warranty, express or implied, or assumes any legal liability or responsibility for the accuracy, completeness, or usefulness of any information, apparatus, product, or process disclosed, or represents that its use would not infringe privately owned rights. Reference herein to any specific commercial product, process, or service by trade name, trademark, manufacturer, or otherwise does not necessarily constitute or imply its endorsement, recommendation, or favoring by the United States Government or any agency thereof. The views and opinions of authors expressed herein do not necessarily state or reflect those of the United States Government or any agency thereof. 


\section{DISCLAIMER}

Portions of this document may be illegible in electronic image products. Images are produced from the best available original document. 


\section{Printed in the United States of America. Available from National Technical Information Service \\ U.S. Department of Commerce \\ 5285 Port Royal Road, Springfield, Virginia 22161 \\ Price: Printed Copy $\$ 6.00$; Microfiche $\$ 2.25$}

This report was prepared as an account of work sponsored by the United States Government. Neither the United States nor the Energy Research and Development Administration/United States Nuclear Regulatory Commission, nor any of their employees, nor any of their contractors, subcontractors, or their employees, makes any warranty, express or implied, or dssulıtes any Icgal liability or respnnsibility for the accuracy, completeness or usefulness of any information, apparatus, product or process disclosed, or represents that its use would not infringe privately owned rights. 
AN EVALUATION AND SUMMARY OF A STUDY OF THE LONG-TERM MULTIAXIAL CREEP BEHAVIOR OF CONCRETE

by

Thomas W. Kennedy

Research Report Number 3899-2

This report was prepared as an account of work

sponsored or the United States Finvernment. Neither

the United States nor the United States Energy Research and Development Administration, nor any of theis employees, nor any of their contractors, subcontractors, of their employees. makes any warranty, express or implied, or assumes any legal
liability or responsibility for the sccuracy, completeness or usefulness of any information, apparatus, product or

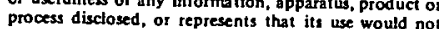
infringe privately owned rights.

prepared for

Oak Ridge National Laboratory

\author{
operated by \\ Union Carbide Corporation \\ for the
}

U.S. Energy Research and Development

Administration

December 1975

CONTRACT NO. W-7405-ENG-26

DISTRIBUTION OF THIS DOCUMENT IS UNLIMITED 


\section{THIS PAGE}

\section{WAS INTENTIONALLY \\ LEFT BLANK}


PREFACE

This is the seventh and final report of a series of reports dealing with the findings of a research project conducted at The University of Texas at Austin and concerned with the evaluation of the creep behavior of concrete subjected to triaxial compressive stresses and elevated temperature. This report evaluates the overall test program, including the specimens, and summarizes the findings of the study, which was initiated in February 1.967 and terminated in June 1975.

The experimental investigation was conducted and financed under Union Carbide Subcontract 2864 , and three reports were prepared. Two additional reports were prepared and financed under Union Carbide Subcontract 3661, and two reports, including this final report, have been prepared under Union Carbide Subcontract 3899. All three contracts were with the Oak Ridge National Laboratory, which is operated by Union Carbide Corporation for the United States Energy Research and Development Administration.

The planning and conducting of the experimental investigation required the assistance and cooperation of many individuals and organizations; the author would like to acknowledge the cooperation and assistance obtaincd from the Concrete Division of the Waterways Experiment Station, Vicksburg, Mississippi, and the Department of Civil Engineering of the University of California at Berkeley. In addition, special thanks are extended to Dr. J. P. Callahan, Manager of the Prestressed Concrete Pressure Vessel Program Office, and Mr. G. D. Whitman, Manager of the Solid Mechanics Department, of the Oak Ridge National Laboratory, whose active participation and support helped this investigation to be successfully conducted, and to $\mathrm{Dr}, \mathrm{J}$. M. Corum and $\mathrm{Mr}$. J. G. Stradley of the Oak Ridge National Laboratory. Appreciation is also extended to Professor Clyde E. Kesler, Department of Civil Engineering, University of Illinois, who served as a consultant to the original project.

Numeruus other individuals were associated with various phases of the project and their roles in the successful completion of the study are acknowledged 
in the individual reports prepared on the various phases of the study. The author would like to acknowledge Mr. Victor N. Toth and Ms. Nancy Webster for their efforts and assistance in the summarization and evaluation of the study and findings and the preparation of this report.

Thomas W. Kennedy

December 1975 
TABLE OF CONTENTS

PREFACE . . . . . . . . . . . . . . . . . . . . . . . iii

CHAPTER 1. INTRODUCTION . . . . . . . . . . . . . . . . . 1

CHAPTER 2. EXPERIMENTAL DESIGN AND PROCEDURES

Test Conditions . . . . . . . . . . . . . . . . . . . . 3

Test Temperature . . . . . . . . . . . . ..... 3

Curing Time... . . . . . . . . . . . . . . . . . . . 3

Curing History . . . . . . . . . . . . . . . . . . . 3

State of Stress....................... 4

Specimens . . . . . . . . . . . . . . . . . . . 4

Mixture Design . . . . . . . . . . . . . . . . . . . 4

Preparation of Specimens................... . 8

Batches and Specimens... . . . . . . . . . . . 8

Instrumentation . . . . . . . . . . . . . . . . . 8

Mixing . . . . . . . . . . . . . . . . . . 8

Casting........................ 13

Curing and Sealing ................. 13

Loading and Testing . . . . . . . . . . . . . . . . . 15

Testing Temperature . . . . . . . . . . . . . . 15

Loading System . . . . . . . . . . . . . . . . . 15

Strain Measuremenls . . . . . . . . . . . . . . . . . . 19

CHAPTER 3. SUMMARY AND EVALUATION OF FINDINGS

Strength and Instantaneous Characteristics . . . . . . . . . . . 21

Compressive and Tensile Strengths . . . . . . . . . . . . 21

Instantaneous Strains and Elastic Properties . ... . . . . 21

Shrinkage Strains . . . . . . . . . . . . . . . . . . . 23

Shrinkage During Curing... . . . . . . . . . . . 23

Shrinkage During Testing of 90-Day Specimens . . . . . . . 29

Shrinkage During Loading Period of 183 and

365-Day Specimens ................. . 31

Total Strains in Stressed Specimens . . . . . . . . . . . . . 31

Creep Strains and Behavior . . . . . . . . . . . . . . . 34

Preliminary Analysis of 90-Day Specimens . . . . . . . . 39

Long-Term Behavior .. . . . . . . . . . . . . . 54

Creep Poisson's Ratio... . . . . . . . . . . . . . 59

Prediction of Creep Behavior . . . . . . . . . . . . . . . 62

Regression Equations . . . . . . . . . . . . . . . 63 
Unit Creep Function Equations . . . . . . . . . . . . . 63

Recovery after the Removal of Loads . . . . . . . . . . . . . 77

Factors Affecting Recovery . . . . . . . . . . . . . 77

Relationships Between Instantaneous Loading, Creep, and Recovery ...................... . 88

Recovery Poisson's Ratio for 90-Day Specimens . . . . . . . . 91

Recovery Poisson's Ratio for 183 and 365-Day Sperimens . . . 92

Estimation of Recovery Strains by Superposition . . . . . . . 92

CHAPTER 4. EVALUATION OF TEST PROGRAM

Equipment and Instrumentation . . . . . . . . . . . . . . . . 97

Loading Unil . . . . . . . . . . . . . . . . . . . 97

Hydraulic System . . . . . . . . . . . . . . . . . 101

Environmental Control . . . . . . . . . . . . . . 102

Instrumentation . . . . . . . . . . . . . . 103

Gage Placement . . . . . . . . . . . . . . . . . . 110

Concrete and Specimens . . . . . . . . . . . . . . . . . . 111

Experiment Design . . . . . . . . . . . . . . . . 115

CHAPTER 5.' CONCLUSIONS AND RECOMMENDATIONS

Technical Conclusions and Findings . . . . . . . . . . . . . 117

Strength . . . . . . . . . . . . . . . . . . . . . 117

Instantaneous and Elastic Properties . . . . . . . . 117

Thermal and Shrinkage Characteristics... . . . . . . . 118

Total Strains... . . . . . . . . . . . . . . . . . 118

Creep Strains and Behavior . . . . . . . . . . . . . 118

Creep Pnisson's Ratio.. . . . . . . . . . . . . . . . . . 119

Predirtion of Creep Behnvior . . . . . . . . . . . . . . 119

Instantaneous Recovery . . . . . . . . . . . . . 120

Creep Recovery .. . . . . . . . . . . . . . 120

Conclusions and Recommendations Concerning the Experimental

Program . . . . . . . . . . . . . . . . . . . 121

Recommendations for Future Studies . . . . . . . . . . . . 122

REFERENCES . . . . . . . . . . . . . . . . . . . . . . . 125

APPENDIX A. TOTAL STRAIN RELATIONSHIPS FOR SPECIMENS CURED

FOR 183 AND 365 DAYS . . . . . . . . . . . . . . 127 
CHAPTER 1. INTRODUCTION

An important consideration in the design and safety evaluation of prestressed concrete nuclear reactor vessels is the time-dependent behavior of concrete when it is subjected to different temperatures, curing times, curing histories (or moisture conditions), and loading conditions. The three basic. forms of time-dependent deformation that can occur are shrinkage, creep, and creep recovery. Any one of these three types of deformation can have serious effects on the behavior of a reactor vessel unless carefully considered during design. Because of the long-term nature and complexity of the required tests, information on creep and the factors affecting creep is limited.

At the request of the United States Atomic Energy Commission, the Oak Ridge National Laboratory formulated and coordinated a basic research and development program to develop the technology of prestressed concrete reactor vessels. As a part of this program, an experimental investigation was initiated in February 1967 at The University of Texas at Austin to study the creep behavior of concrete subjected to multiaxial compressive stresses and elevated temperatures. The investigation consisted of measuring strains in cylindrical specimens subjected to 58 test conditions, involving a variety of. multiaxial loading conditions (compressive stresses ranging from zero to 3600 psi), three curing times (90, 183, and 365 days), two curing histories (air-dried and as-cast), and two temperatures $\left(75^{\circ} \mathrm{F}\right.$ and $150^{\circ} \mathrm{F}$ ). After curing, the specimens cured for 90 days were subjected to a prescribed load and temperature for 12 months, followed by a five-month unluaded recovery period at the prescribed temperature. Specimens cured for 183 or 365 days were subjected to uniaxial stresses of 600 or 2400 psi for approximately 5.25 or 4.75 years at $75^{\circ} \mathrm{F}$, followed by a 77-day recovery period. During the curing, loaded, and unloaded-recovery periods, strain measurements were made in order to evaluate the creep and creep recovery behavior of the concrete. The study.was terminated in June 1975, and findings were reported in a series of six reports (Refs 1 , $2,3,4,5$, and 11). 
This report describes the procedures and equipment used in the study and summarizes the findings of an evaluation of the overall program, including the procedures, equipment, instrumentation, and specimens. Chapter 2 describes the total experimental program, including the preparation of specimens, equipment and instrumentation, experimental procedures, and experimental designs. Chapter 3 contains a summary and brief discussion of fiudings of the total study. An evaluation of the test program, including a post-test evaluation of the specimens, is presented in Chapter 4. Conclusions and recommendations are contalned in Chapter 5 . 
CHAPTER 2. EXPERIMENTAL DESIGN AND PROCEDURES

The purpose of the study was to obtain information on the creep behavior of concrete subjected to multiaxial compressive stresses at different temperatures. The tests consisted of applying compressive loads along the three principal axes of cylindrical concrete specimens and measuring the strains in the axial and radial directions throughout the test period. Since concrete exhibits two basic forms of time-dependent deformation, creep and shrinkage, i.t was necessary to measure strain in both loaded and unloaded companion specimens in order to separate the portion of the strain produced by shrinkage from the portion resulting from creep. Details of the experiment, specimens, and test procedures are described below.

\section{TEST COND.ITIONS}

Although many factors affect the creep and creep recovery behavior of concrete, only temperature during the loaded and unloaded recovery periods, curing time, curing history, and state of stress were studied.

\section{$\underline{\text { Test Temperature }}$}

During the loading period, the concrete was subjected to either 75 or $150^{\circ} \mathrm{F}$. The $75^{\circ} \mathrm{F}$ temperature approximates the temperature at the outer. surface of a reactor, while $150^{\circ} \mathrm{F}$ approximates the temperature at the inner surface of the vessel.

\section{Euring Time}

The major portion of the study involved specimens cured for a period of 90 days prior to being loaded. In addition, a limited number of specimens were cured for 183 or 365 days prior to loading in order to ascertain the effects of curing time.

Curing History

Two curing histories, designated as as-cast and air-dried, were selected 
for study. The as-cast condition represents the curing history of concrete at the inner face of a concrete reactor vessel or of concrete in any massive structure, except near a free-air surface, and involved sealing the specimens shortly after casting to maintain their initial moisture condition. The airdried condition is representative of the curing history of the concrete at the outer surface of a concrete reactor vessel or other mass-concrete seructure or of concrete in relatively thin members. In this case, the concrete was allowed to air-dry for most of the curing period.

\section{$\underline{\text { State of Stress }}$}

Specimens were loaded triaxially at flve stress levels, ranging from 11 to 3600 psi for both the axial stress and radial confining stress.

\section{SPECIMENS}

Three basic types of specimens were utilized in this investigation: creep, shrinkage, and strength. All creep and shrinkage specimens were 6 inches in diameter by 16 inches in length and were attached to 3-inch-thick.steel end caps through which the axial load was applied (Fig 1). The specimens were cast horizontally in specially designed molds. The tensile and compressive strength specimens were 6 inches in diameter by 12 inches in length and were cast verticali.y in standard $6 \times 12$-inch molds.

One hundred two creep and shrinkage specimens and 328 strength specimens were cast and investigated under the test conditions summarized in Table 1 . These 58 test conditions involved two temperatures, two curing histories, three curing periods, and triaxial stress conditione ranging from 0 to 3600 psi for both the axial stress and the radial confining stress. The various curing and loading conditions are described in Table 2 for each of the two curing histories.

\section{MIXTURE DESIGN}

The mixture design and all materials utilized in this investigation except water were furnished by the Concrete Division, Waterways Experiment Staliun, Vicksburg, Mississippi. Prior to shipping, the materials were proportioned into thirteen 12-cubic-foot batch quantities and placed in sealed containers. 


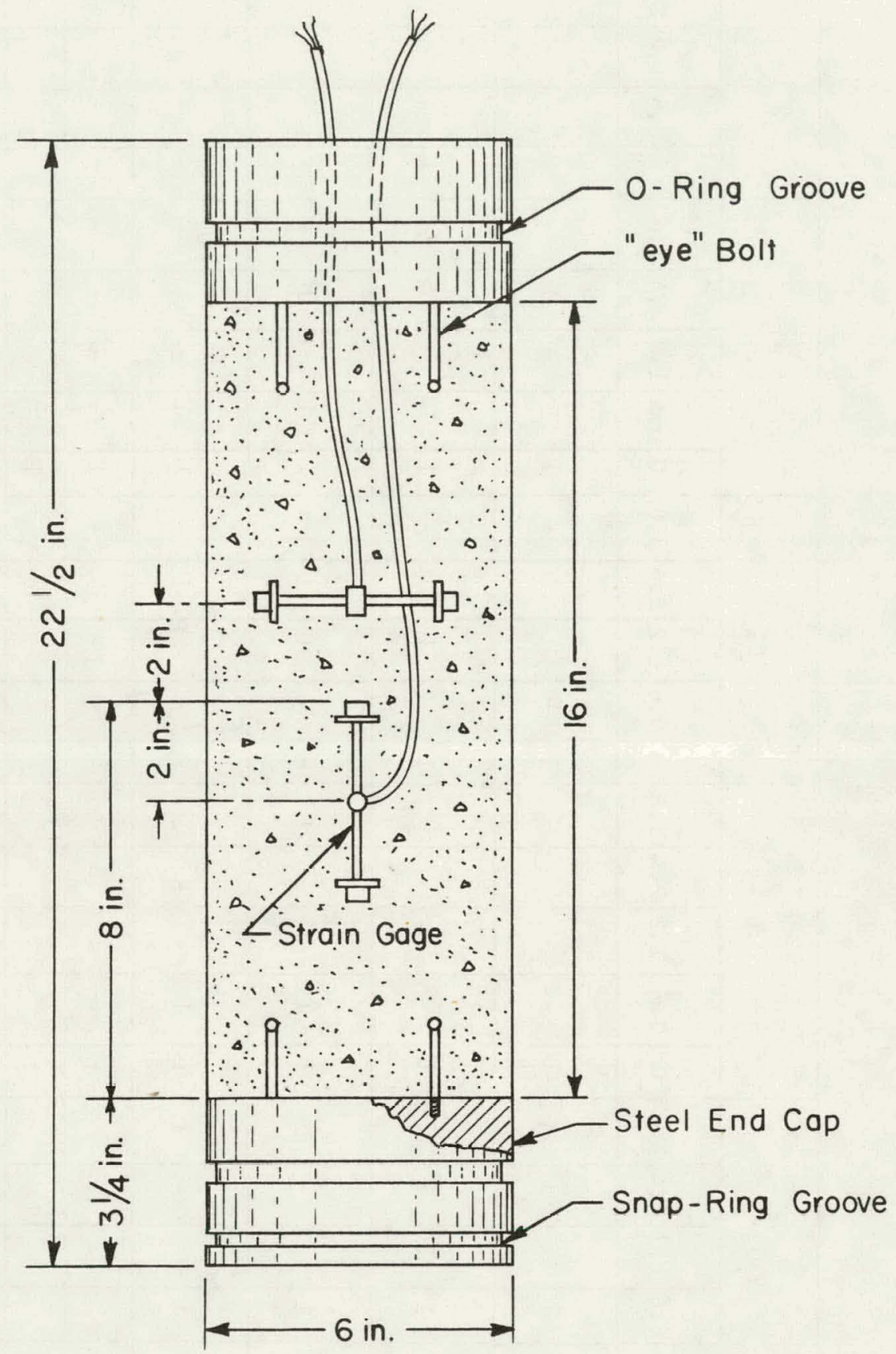

Fig 1. Test specimen and gage locations. 
TABLE 1. SUMMARY OF EXPERIMENTAL PROGRAM

\begin{tabular}{|c|c|c|c|c|c|c|c|c|c|c|c|c|c|c|c|c|c|c|c|c|c|c|c|c|c|c|c|}
\hline \multirow{2}{*}{\multicolumn{3}{|c|}{$\begin{array}{l}\begin{array}{l}\text { Axial } \\
\text { Stress } \sigma_{a}, k s i\end{array} \\
\begin{array}{l}\text { Radial } \\
\text { Stress } \sigma_{r}, k s i\end{array}\end{array}$}} & \multicolumn{5}{|c|}{0} & \multicolumn{5}{|c|}{0.6} & \multicolumn{5}{|c|}{1.2} & \multicolumn{5}{|c|}{2.4} & \multicolumn{5}{|c|}{3.6} \\
\hline & & & 0 & 0.6 & 1.2 & 2.4 & 3.6 & 0 & 0.6 & 1.2 & 2.4 & 3.6 & 0 & 0.6 & 1.2 & 2.4 & 3.6 & 0 & 0.6 & 1.2 & 2.4 & 3.6 & 0 & 0.6 & 1.2 & 2.4 & 3.6 \\
\hline \multirow{2}{*}{ 음 } & \multirow{2}{*}{ 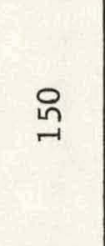 } & $\begin{array}{ll}1 & 1 \\
\text { in } & 0 \\
\pi & \pi\end{array}$ & $7 *$ & 1 & 1 & 1 & 1 & 1 & - & - & - & - & 1 & - & 1 & 1 & - & 1 & 1 & - & 1 & - & 1 & - & - & - & 1 \\
\hline & & 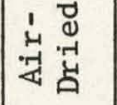 & $7 *$ & 1 & 1 & 1 & 1 & 1 & - & - & - & - & 1 & - & 1 & 1 & - & 1 & 1 & $\therefore$ & 1 & - & 1 & - & - & - & 1 \\
\hline \multirow{2}{*}{ 응 } & \multirow{2}{*}{$\stackrel{n}{N}$} & 皇 & $7 *$ & 1 & - & - & $z$ & 1 & 1 & - & - & 1 & - & - & 1 & 1 & - & 1 & 1 & - & 1 & - & - & - & 1 & - & 1 \\
\hline & & 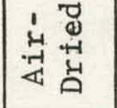 & $7 *$ & 1 & - & - & $I$ & 1 & 1 & - & - & 1 & - & - & 1 & 1 & - & 1 & 1 & - & 1 & - & - & - & 1 & - & 1 \\
\hline \multirow{2}{*}{$\underset{\infty}{m}$} & \multirow{2}{*}{$\stackrel{\operatorname{Ln}}{N}$} & $\begin{array}{c}\text { As- } \\
\text { Cast }\end{array}$ & $1 * *$ & - & - & - & - & 1 & - & - & - & - & - & - & - & - & - & 1 & - & - & - & - & - & - & - & - & - \\
\hline & & \begin{tabular}{|c|} 
Air- \\
Dried \\
\end{tabular} & 1 & & & & & 1 & & & & & & & & & & 1 & & & & & & & & & \\
\hline \multirow{2}{*}{ in } & \multirow{2}{*}{$\stackrel{\text { ๓n }}{\sim}$} & $\begin{array}{l}\text { As- } \\
\text { Cast }\end{array}$ & $1 * *$ & - & - & - & - & 1 & - & - & - & - & - & - & - & - & - & 1 & - & - & - & - & - & - & - & - & - \\
\hline & & $\begin{array}{l}\text { Air- } \\
\text { Dried }\end{array}$ & 1 & & & & & 1 & & & & & & & & & & 1 & & & & & & & & & \\
\hline 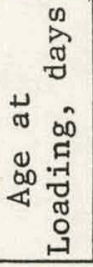 & 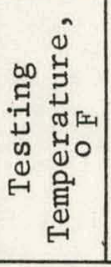 & 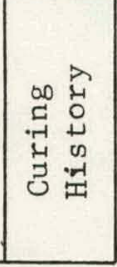 & \multicolumn{25}{|c|}{$\begin{array}{l}\text { Numerals i } \\
\text { Snrinkage }\end{array}$} \\
\hline
\end{tabular}


TABLE 2. SUMMARY OF MAJOR TEST CONDITIONS*

\begin{tabular}{|c|c|c|c|c|c|c|c|}
\hline $\begin{array}{c}\text { Major } \\
\text { Condition }\end{array}$ & Batch ${ }^{\#}$ & $\begin{array}{c}\text { Temp. } \\
\circ \mathrm{F}\end{array}$ & $\begin{array}{c}\text { Axial } \\
\text { Stress } \\
\sigma_{a}, \\
\text { psi }\end{array}$ & $\begin{array}{c}\text { Radial } \\
\text { Stress } \\
\sigma_{r}, \\
\text { psi }\end{array}$ & $\begin{array}{l}\text { Test } \\
\text { Unit }\end{array}$ & $\begin{array}{c}\text { Age at } \\
\text { Loading, } \\
\text { days }\end{array}$ & $\begin{array}{l}\text { Type of } \\
\text { Loading }\end{array}$ \\
\hline $\begin{array}{l}1 \\
2\end{array}$ & $\begin{array}{l}\text { B } \\
\text { E }\end{array}$ & $\begin{array}{l}75 \\
75\end{array}$ & $\begin{array}{r}2400 \\
600\end{array}$ & $\begin{array}{l}0 \\
0\end{array}$ & $\begin{array}{l}5 * * \\
6\end{array}$ & $\begin{array}{l}90 \\
90\end{array}$ & Uniaxial \\
\hline $\begin{array}{l}3 \\
4\end{array}$ & $\begin{array}{l}\text { A } \\
\text { F }\end{array}$ & $\begin{array}{l}75 \\
75\end{array}$ & $\begin{array}{l}0 \\
0\end{array}$ & $\begin{array}{r}3600 \\
600\end{array}$ & $\begin{array}{l}2 \\
1 * *\end{array}$ & $\begin{array}{l}90 \\
90\end{array}$ & Biaxial \\
\hline $\begin{array}{r}5 \\
6 \\
7 \\
8 \\
9 \\
10 \\
11 \\
12\end{array}$ & $\begin{array}{l}\text { D } \\
\text { D } \\
\text { F } \\
\text { C } \\
\text { B } \\
\text { C } \\
\text { G } \\
\text { E }\end{array}$ & $\begin{array}{l}75 \\
75 \\
75 \\
75 \\
75 \\
75 \\
75 \\
75\end{array}$ & $\begin{array}{r}3600 \\
3600 \\
2400 \\
2400 \\
1200 \\
1200 \\
600 \\
600\end{array}$ & $\begin{array}{r}3600 \\
1200 \\
2400 \\
600 \\
2400 \\
1200 \\
3600 \\
600\end{array}$ & $\begin{array}{c}3 * * \\
7 * * \\
12 \\
9 \\
10 * * \\
11 \\
4 * * \\
8\end{array}$ & $\begin{array}{l}90 \\
90 \\
90 \\
90 \\
90 \\
90 \\
90 \\
90\end{array}$ & Triaxial \\
\hline $\begin{array}{l}13 \\
14 \\
15 \\
16\end{array}$ & $\begin{array}{l}\text { B } \\
\text { F } \\
\text { D } \\
B\end{array}$ & $\begin{array}{l}150 \\
150 \\
150 \\
150\end{array}$ & $\begin{array}{r}3600 \\
2400 \\
1200 \\
600\end{array}$ & $\begin{array}{l}0 \\
0 \\
0 \\
0\end{array}$ & $\begin{array}{l}13 \\
21 \\
14 * * \\
20 * *\end{array}$ & $\begin{array}{l}90 \\
90 \\
90 \\
90\end{array}$ & Uniaxial \\
\hline $\begin{array}{l}17 \\
18 \\
19 \\
20\end{array}$ & $\begin{array}{l}\text { C } \\
\text { E } \\
\text { D } \\
\text { A }\end{array}$ & $\begin{array}{l}150 \\
150 \\
150 \\
150\end{array}$ & $\begin{array}{l}0 \\
0 \\
0 \\
0\end{array}$ & $\begin{array}{r}3600 \\
2400 \\
1200 \\
600\end{array}$ & $\begin{array}{l}25 * * \\
24 \\
23 \\
22 * *\end{array}$ & $\begin{array}{l}90 \\
90 \\
90 \\
90\end{array}$ & Biaxial \\
\hline $\begin{array}{l}21 \\
22 \\
23 \\
24 \\
25\end{array}$ & $\begin{array}{l}\mathrm{F} \\
\mathrm{G} \\
\mathrm{E} \\
\mathrm{D} \\
\mathrm{C}\end{array}$ & $\begin{array}{l}150 \\
150 \\
150 \\
150 \\
150\end{array}$ & $\begin{array}{l}3600 \\
2400 \\
2400 \\
1200 \\
1200\end{array}$ & $\begin{array}{r}3600 \\
2400 \\
600 \\
2400 \\
1200\end{array}$ & $\begin{array}{l}15 \\
19 * * \\
18 \\
17 \\
16 * *\end{array}$ & $\begin{array}{l}90 \\
90 \\
90 \\
90 \\
90\end{array}$ & Triaxial \\
\hline $\begin{array}{l}26 \\
27 \\
28 \\
29\end{array}$ & $\begin{array}{l}\mathrm{H} \\
\mathrm{H} \\
\mathrm{I} \\
\mathrm{I}\end{array}$ & $\begin{array}{l}75 \\
75 \\
75 \\
75\end{array}$ & $\begin{array}{r}600 \\
600 \\
2400 \\
2400\end{array}$ & $\begin{array}{l}0 \\
0 \\
0 \\
0\end{array}$ & $\begin{array}{l}29 * * \\
26 \\
28 \\
27 * *\end{array}$ & $\begin{array}{l}183 \\
365 \\
183 \\
365\end{array}$ & Uniaxial \\
\hline
\end{tabular}

* For each major condition there was both an air-dried and an as-cast specimen.

**In units with asterisks, the as-cast specimens were placed in the upper radial sleeve; in units without asterisks, the as-cast specimens were placed in the lower radial sleeve.

\# Specimens were cast from nine, 12 cubic-foot batches designated A through I. 
The materials consisted of Type II cement and crushed fine and coarse limestone aggregates with a 3/4-inch maximum size. The concrete was designed for a 28-day compressive strength of $6000 \pm 600$ psi for specimens cured while submerged in lime-saturated water, standard cured (ASTM C-192). Mix proportions and a summary of the results of engineering tests on the materials are contained in Ref 3. A brief summary of the concrete design proportions is shown in Table 3 .

PREPARATION OF SPECIMENS

Ninc 12-cubic-fuul balches of concrete were prepared. All specimens required for the 29 major test conditions were cast from these hatches, which were designated A through I (Table 2). The first seven batches (A through $G$ ) provided concrete for the portion of the study concerned with 90-day 1oadings. Batches $\mathrm{H}$ and I provided concrete for the 183 and 365-day loading conditions and for replacements for specimens which failed in previous batches.

\section{Batches and Specimens}

The various combinations of test variables for the creep and shrinkage specimens are shown in Table 4 and the strength specimens are summarized in Table 5.

The number and type of specimens for each batch, as well as the conditions and order of casting for each specimen, are described in Ref 3.

Instrumentation

Vibrating wire strain gages were embedded in each $6 \times 16$-inch specimen. One gage was oriented in the axial direction and nne in the lateral dircction, as shown in Fig 1 . One hundred two $6 \times 16$-inch specimens were tested, requiring a total of 204 gages. The gages were positioned so that the center of each gage was 2 inches from the centerline of the specimen (Fig 1). Both gages were installed on the same plane and held in position, as shown in Figs 2 and 3.

\section{Mixing}

The following mixing procedure, which was essentially that utilized by 
TABLE 3. MIX DESIGN SUMMARY

Water-cement ratio, by weight

0.425

Cement content, sacks/cu yd

7.25

Maximum size of coarse aggregate, inches

$3 / 4$

Slump, inches

2

Mix Proportion, Percent

\begin{tabular}{|c|c|c|c|}
\hline Materia 1 & Size Range & By Volume & By Weight \\
\hline Cement & --- & 15.5 & 17.8 \\
\hline Fine aggregate & Sand & 37.1 & 35.9 \\
\hline Coarse aggregate (A) & No. 4 & 14.2 & 13.9 \\
\hline Coarse aggregate (B) & $3 / 8$ inch & 16.6 & 16.2 \\
\hline Coarse aggregate (C) & $1 / 2$ inch & 16.6 & 16.2 \\
\hline
\end{tabular}


TABLE 4. EXPERTMENTAL DESIGN FOR CREEP AND SHRINKAGE SPECIMENS

\begin{tabular}{|c|c|c|c|c|c|c|c|}
\hline \multirow[t]{2}{*}{ 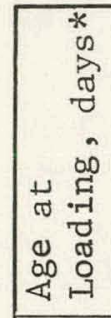 } & \multirow{2}{*}{ 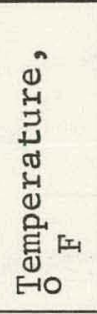 } & \multirow{2}{*}{$\begin{array}{l}\text { Axia 1 } \\
\text { Load, } \\
\text { psi }\end{array}$} & \multirow{2}{*}{$\begin{array}{l}\text { Radial } \\
\text { Load, } \\
\text { psi }\end{array}$} & \multicolumn{2}{|c|}{ Creep Specimens** } & \multicolumn{2}{|c|}{$\begin{array}{l}\text { Companion } \\
\text { Shrinkage } \\
\text { Specimens } * *\end{array}$} \\
\hline & & & & As-Cast & Air-Dried & As-Cast & Air-Dried \\
\hline \multirow{24}{*}{ 으 } & \multirow{11}{*}{$\stackrel{10}{\sim}$} & $\begin{array}{r}0 \\
0\end{array}$ & $\begin{array}{r}600 \\
3600 \\
\end{array}$ & $\begin{array}{l}F-13 \\
H-22 r\end{array}$ & $\begin{array}{l}F-42 \\
H-14 r\end{array}$ & $\begin{array}{l}F-23 \\
A-8\end{array}$ & $\begin{array}{l}\mathrm{F}-17 \\
\mathrm{H}-1\end{array}$ \\
\hline & & 600 & $n$ & $E-39$ & $\mathrm{E}-40$ & $E-28$ & $\mathrm{E}-23 * * * *$ \\
\hline & & 600 & 600 & $E-5$ & $E-13$ & $E-28$ & $\mathrm{E}-23$ \\
\hline & & 600 & 3600 & $G-35$ & $G-30$ & $G-18$ & $G-10$ \\
\hline & & 1200 & 1200 & $C-16 x$ & $C-17$ & $C-39$ & $C-6$ \\
\hline & & 1200 & 2400 & $\mathrm{~B}-41$ & $B-42$ & $B-29$ & $B-23$ \\
\hline & & 2400 & 0 & $B-7$ & $B-19$ & $B-29$ & $B-23$ \\
\hline & & 2400 & 600 & $C-23$ & $C-11$ & $C-39$ & $C-6$ \\
\hline & & 2400 & 2400 & $F-9$ & $F-30$ & $F-23$ & $\mathrm{~F}-17$ \\
\hline & & 3600 & 1200 & $D-26$ & $D-44$ & $D-20$ & $D-33$ \\
\hline & & 3600 & 3600 & $D-31$ & $D-40$ & $D-20$ & $D-33$ \\
\hline & \multirow{13}{*}{ 움 } & 0 & 600 & $A-35$ & $I-13 r f$ & $A-22$ & $I-1$ \\
\hline & & 0 & 1200 & $I-27 r$ & $D-3$ & $T-2.1$ & $D-23$ \\
\hline & & 0 & 2400 & $E-43$ & $E-1$ & $E-10$ & $E-42$ \\
\hline & & 0 & 3600 & $I-16 r$ & $C-13 f$ & $1-21$ & $I-1$ \\
\hline & & 600 & 0 & $B-4$ & $B-1$ & $B-13$ & $B-26$ \\
\hline & & 1200 & 0 & $D-15$ & $\mathrm{D}-22$ & $\mathrm{D}-12$ & $D-23$ \\
\hline & & 1200 & 1200 & $C-12$ & $C-46 x$ & $C-41$ & $C-36$ \\
\hline & & 1200 & 2400 & $D-2 x$ & $D-41$ & $D-12$ & $D-23$ \\
\hline & & 2400 & & $F-33$ & $F-34$ & $F-15$ & $F-21$ \\
\hline & & 2400 & 600 & E-18 & $E-4$ & $E-10$ & $E-42$ \\
\hline & & 2400 & 2400 & $G-9$ & $G-19$ & $G-1$ & $G-21$ \\
\hline & & 3600 & & $B-16$ & $B-5$ & $B-13$ & $B-26$ \\
\hline & & 3600 & 3600 & $\mathrm{~F}-20$ & $\mathrm{I}-30 \mathrm{rf}$ & $\mathrm{F}-15$ & $\mathrm{~F}-21$ \\
\hline \multirow{2}{*}{$\underset{\substack{\infty \\
-1}}{ }$} & \multirow{2}{*}{$\stackrel{10}{N}$} & 600 & 0 & $\mathrm{H}-45$ & $I-39$ & $\mathrm{H}-28$ & $\mathrm{I}-17 \quad * * *$ \\
\hline & & 2400 & 0 & $\mathrm{H}-34$ & $1-20$ & $\mathrm{H}-28$ & $I-17$ \\
\hline \multirow{2}{*}{ ํㅐ } & \multirow{2}{*}{ 늣 } & & & & $\overline{\mathrm{H}-31}$ & & $H-35 * k *$ \\
\hline & & 2400 & 0 & $\begin{array}{l}\mathrm{H}=3 \\
\mathrm{H}=24\end{array}$ & $\begin{array}{l}\mathrm{H}=31 \\
\mathrm{H}-17\end{array}$ & $\begin{array}{l}\mathrm{H}-28 \\
\mathrm{H}-28\end{array}$ & $\begin{array}{l}\mathrm{H}-35 \\
\mathrm{H}-35\end{array}$ \\
\hline
\end{tabular}

* Age at loading for creep specimens.

$*$ Specimen designation: the letter indicates the batch and the numeral indicates the specimen within the batch.

w'st Specimens used in the evaluation of the effect of curing time and the long term creep behavior.

$r=$ Replacement specimens.

$\mathrm{x}=$ Radial pressure zero $\left(\sigma_{\mathrm{r}}=0\right)$ due to oil leak in specimen.

$\mathrm{f}=$ Specimen failed shortly after loading. 
TABLE 5. EXPERIMENTAL DESIGN FOR STRENGTH SPECIMENS

\begin{tabular}{|c|c|c|c|c|c|c|c|c|c|c|c|c|c|c|}
\hline \multirow{2}{*}{\multicolumn{2}{|c|}{$\begin{array}{c}\text { Age at } \\
\text { Testing, } \\
\text { Days }\end{array}$}} & \multirow{2}{*}{$\begin{array}{c}\text { Curing } \\
\text { Conditions }\end{array}$} & \multirow{2}{*}{$\begin{array}{c}\text { Temperature, } \\
\text { F }\end{array}$} & \multicolumn{11}{|c|}{ Number of Specimens per Batch* } \\
\hline & & & & A & B & C & $\mathrm{D}$ & $\mathrm{E}$ & $\mathrm{F}$ & G & H & I & Tot: & \\
\hline \multirow{8}{*}{ 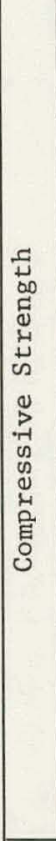 } & 28 & $\begin{array}{l}\text { Standard } \\
\text { As-Cast } \\
\text { Air-Dried }\end{array}$ & 75 & $\begin{array}{l}3 \\
3 \\
3\end{array}$ & $\begin{array}{l}6(3) \\
3 \\
3\end{array}$ & $\begin{array}{l}6(5) \\
3 \\
3\end{array}$ & $\begin{array}{l}6 \\
3 \\
3\end{array}$ & $\begin{array}{l}6(4) \\
3 \\
3\end{array}$ & $\begin{array}{l}6(5) \\
3 \\
3\end{array}$ & $\begin{array}{l}3 \\
3 \\
3\end{array}$ & $\begin{array}{l}3 \\
3 \\
3\end{array}$ & $\begin{array}{l}3 \\
3(1) \\
3\end{array}$ & $\begin{array}{l}42(35) \\
27(25) \\
27\end{array}$ & \multirow{8}{*}{$\begin{array}{c}282 \\
(252)\end{array}$} \\
\hline & 90 & $\begin{array}{l}\text { Standard } \\
\text { As-Cast } \\
\text { Air-Dried }\end{array}$ & 75 & $\begin{array}{l}3 \\
3(2) \\
3(2)\end{array}$ & $\begin{array}{l}6(3) \\
3 \\
3\end{array}$ & $\begin{array}{l}6(4) \\
3 \\
3\end{array}$ & $\begin{array}{l}6 \\
3 \\
3\end{array}$ & $\begin{array}{l}6(4) \\
3 \\
3\end{array}$ & $\begin{array}{l}6(4) \\
3 \\
3\end{array}$ & $\begin{array}{l}3 \\
3 \\
3\end{array}$ & $\begin{array}{l}3(2) \\
3 \\
3\end{array}$ & $\begin{array}{l}3(1) \\
3(1) \\
3\end{array}$ & $\begin{array}{l}42(30) \\
27(24) \\
27(26)\end{array}$ & \\
\hline & \multirow{2}{*}{183} & As-Cast & $\begin{array}{r}75 \\
150\end{array}$ & $\begin{array}{l}2 \\
2\end{array}$ & - & - & - & - & - & $\begin{array}{l}2 \\
2\end{array}$ & $\begin{array}{l}3 \\
-\end{array}$ & $\begin{array}{l}2(1) \\
2\end{array}$ & $\begin{array}{l}9(8) \\
6\end{array}$ & \\
\hline & & Air-Dried & $\begin{array}{r}75 \\
150\end{array}$ & $\begin{array}{l}2 \\
2\end{array}$ & - & - & - & - & - & $\begin{array}{l}2 \\
2\end{array}$ & $\begin{array}{l}3 \\
-\end{array}$ & $\begin{array}{l}2 \\
2\end{array}$ & $\begin{array}{l}9 \\
6\end{array}$ & \\
\hline & 265 & As-Cast & $\begin{array}{r}75 \\
150\end{array}$ & $\begin{array}{l}2 \\
2\end{array}$ & - & - & - & - & - & $\begin{array}{l}2 \\
2\end{array}$ & $\begin{array}{l}3 \\
-\end{array}$ & $\begin{array}{l}2 \\
2\end{array}$ & $\begin{array}{l}9 \\
6\end{array}$ & \\
\hline & 年 & Air-Dried & $\begin{array}{r}75 \\
150\end{array}$ & $\begin{array}{l}2 \\
2\end{array}$ & - & - & - & - & $\begin{array}{l}- \\
-\end{array}$ & $\begin{array}{l}2 \\
2\end{array}$ & $\begin{array}{l}3 \\
-\end{array}$ & $\begin{array}{l}2 \\
2\end{array}$ & $\begin{array}{l}9 \\
6\end{array}$ & \\
\hline & \multirow{2}{*}{538} & As-Cast & $\begin{array}{r}75 \\
150\end{array}$ & $\begin{array}{l}2 \\
2\end{array}$ & - & - & - & - & - & $\begin{array}{l}2 \\
2\end{array}$ & $\begin{array}{l}3 \\
-\end{array}$ & $\begin{array}{l}2 \\
2\end{array}$ & $\begin{array}{l}9 \\
6\end{array}$ & \\
\hline & & Air-Dried & $\begin{array}{r}75 \\
150\end{array}$ & $\begin{array}{l}2 \\
2\end{array}$ & - & - & - & - & - & $\begin{array}{l}2 \\
2\end{array}$ & $\begin{array}{l}3(2) \\
-\end{array}$ & $\begin{array}{l}2(0) \\
2(1)\end{array}$ & $\begin{array}{l}9(6) \\
6(5)\end{array}$ & \\
\hline \multirow{4}{*}{ 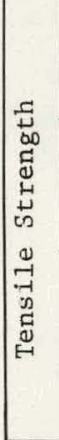 } & 28 & $\begin{array}{l}\text { Standard } \\
\text { As-Cast } \\
\text { Air-Dried }\end{array}$ & 75 & $\begin{array}{l}- \\
-\end{array}$ & $\begin{array}{l}2(i) \\
- \\
(1)\end{array}$ & $\begin{array}{l}2 \\
- \\
-\end{array}$ & $\begin{array}{l}2 \\
2 \\
2\end{array}$ & $\begin{array}{l}2 \\
- \\
-\end{array}$ & $\begin{array}{l}2 \\
- \\
-\end{array}$ & - & - & - & $\begin{array}{c}10(9) \\
2 \\
2(3)\end{array}$ & \multirow{4}{*}{76} \\
\hline & 90 & $\begin{array}{l}\text { Standard } \\
\text { As-Cast } \\
\text { Air-Dried }\end{array}$ & 75 & $\begin{array}{l}- \\
-\end{array}$ & $\begin{array}{l}2 \\
2 \\
2\end{array}$ & $\begin{array}{l}2 \\
2 \\
2\end{array}$ & $\begin{array}{l}2 \\
2 \\
2\end{array}$ & $\begin{array}{l}2 \\
2 \\
2\end{array}$ & $\begin{array}{l}2 \\
2 \\
2\end{array}$ & - & - & - & $\begin{array}{l}10 \\
10 \\
10\end{array}$ & \\
\hline & \multirow{2}{*}{538} & As-Cast & $\begin{array}{r}75 \\
150\end{array}$ & - & $\begin{array}{l}2 \\
2\end{array}$ & $\begin{array}{l}2 \\
2\end{array}$ & - & $\begin{array}{l}2 \\
2\end{array}$ & $\begin{array}{l}2 \\
2\end{array}$ & - & - & - & $\begin{array}{l}8 \\
8\end{array}$ & \\
\hline & & Air-Dried & $\begin{array}{r}75 \\
150\end{array}$ & $\begin{array}{l}- \\
-\end{array}$ & $\begin{array}{l}2 \\
2\end{array}$ & $\begin{array}{l}2 \\
2\end{array}$ & - & $\begin{array}{l}2 \\
2\end{array}$ & $\begin{array}{l}2 \\
2\end{array}$ & - & - & - & $\begin{array}{l}8 \\
8\end{array}$ & \\
\hline
\end{tabular}

*Numbers in parentheses indicate the number of spec-mens actually tested. 


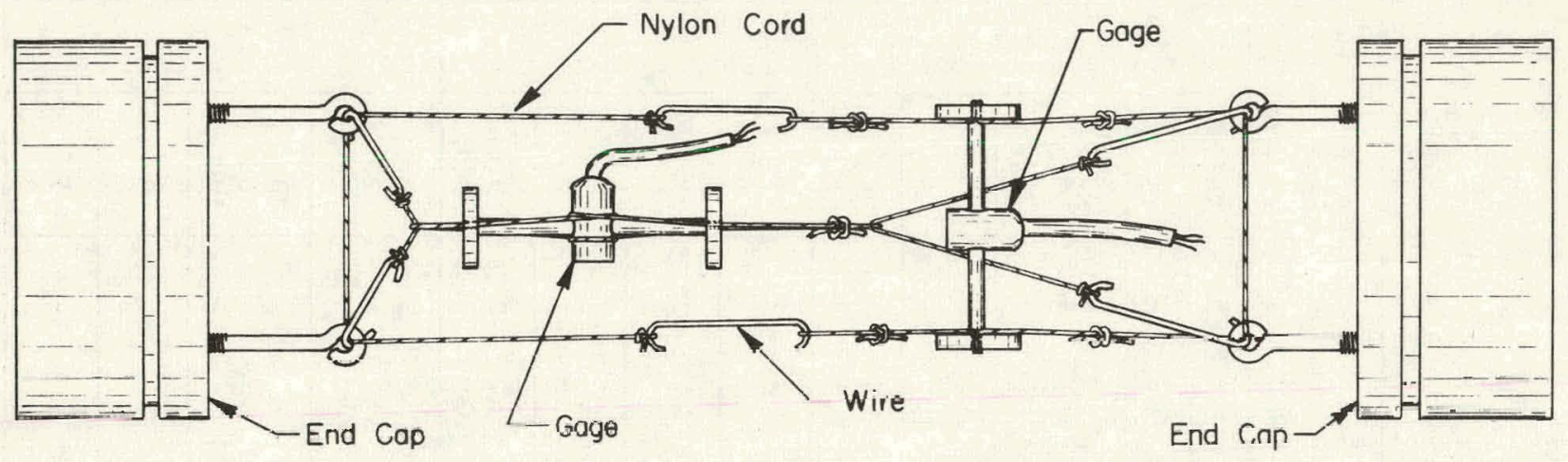

Fig 2. Method of positioning vibrating wire gages.

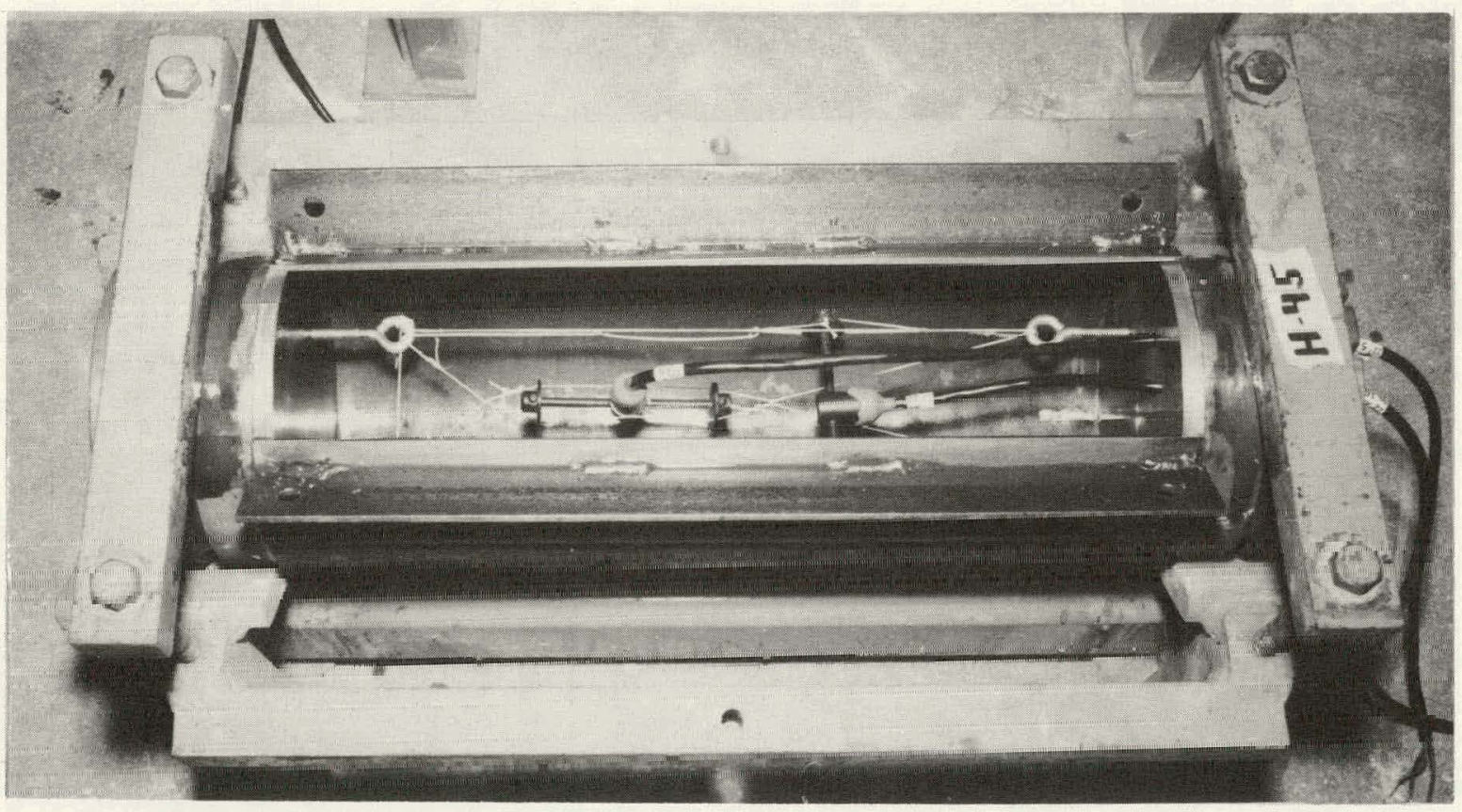

Fig 3. Stee1 mold assemb1y for $6 \times 16$-inch specimen. 
the Waterways Experiment Station in the development of the mixture proportions, was used during the casting of the specimens:

(1) Mixer was pre-dampened, leaving no free water, as follows:

(a) mixer was rotated with free water for at least 15 minutes,

(b) mixer was allowed to drain for at least 10 minutes, and

(c) excess water was removed by blotting with rags.

(2) All coarse aggregate was placed in mixer.

(3) All fine aggregate was placed in mixer.

(4) Mixer was rotated approximately four revolutions.

(5) A11 water was placed in mixer.

(6) Mixer was started and all cement was added in a period of approximately 20 to 40 seconds.

(7) Concrete was mixed for two minutes.

(8) Mixer was stopped for three minutes.

(9) Concrete was mixed for one additional minute.

(10) Concrete was discharged into a damp pan.

\section{$\underline{\text { Casting }}$}

The $6 \times 12$-inch specimens were cast vertically, compacted according to ASTM specification C-192, and vibrated three seconds at a frequency of 3600 cycles per minute. The $6 \times 16$-inch specimens, which were cast horizontally (Fig 3), were compacted by approximately 200 strokes of a 1/4-inch-diameter rod. The specimens were then vibrated five seconds at a frequency of 3600 cycles per minute. A specially constructed curved trowel was used to finish the exposed longitudinal surface of these specimens. The entire casting operation for each batch took approximately 45 minutes. All $6 \times 12$-inch specimens for compressive strength determinations were capped with neat cement four to six hours after casting. The detailed capping procedure is described in $\operatorname{Ref} 3$.

\section{Curing and Sealing}

A11 specimens were cured 24 hours in the laboratory, followed by 24 hours in a 100 percent relative humidity curing room. During the laboratory curing period of 24 hours, the specimens were covered with sheet plastic and wet 
burlap and protected from excessive temperature change. Forms were removed after 24 hours. Subsequent sealing and curing procedures were as follows:

(1) As-Cast Specimens

(a) $6 \times 16$-inch specimens

Tmmediately afler lie specimens were removed from the forms, all surface irregularities were removed by wire brushing and by rubbing the surface with a pumice stone, all surface voids were filled with neat-cement paste, and the specimens were coated with epoxy (Colma Bonding Compound, Epoxy-Polysulfide Systcm, Sika Chemical Corporation) and placed in the fog room. At the end of 48 hours, the sperimens were removed from the fog loum, recoated with epoxy, and sealed in a copper jacket. The specimens were cured an additional 81,174 , or $356 *$ days (83, 176 , or $358 *$ days total curing) at $73.4 \pm 3^{\circ} \mathrm{F}$. At this time, each specimen was placed in a neoprene sleeve, sealed at both ends with neoprene cement and stainless steel bands, and placed in the testing unit. The testing unit and specimens were then brought to testing temperature by placing both in the testing Lemperature environment for an additional seven days (90, 183, or $365^{*}$ days of curing) prior to loading.

(b) $6 \times 12$-inch specimens

The $6 \times 12$-inch specimens were cast in molds containing a 6 -inch OD copper insert. Forty-eight hours after casting, the specimcno wcrc complctcly sealed in cupper and cured for the appropriate number of days at $75^{\circ} \mathrm{F}$. Those specimens which were to be tested 183 days or more after casting were placed in the proper temperature environment at the end of 83 days and remained at this temperature until 24 hours prior to testing at which time the specimens were placed in the testing temperature of $75^{\circ} \mathrm{F}$.

(2) Air-Dried Specimens

(a) $6 \times 16$-inch specimens

Immediately after the specimens were removed from the forms, all surface irregularities were removed by wire brushing and by rubbing the surface with a pumice stone, and all surface voids were filled with a neat-cement paste. At the end of 48 hours, the specimens were submerged and further cured in Limesaturated water at $75^{\circ} \mathrm{F}$ for five days. Subsequent to this, the specimens were stored at 50 percent relative humidity at $75^{\circ} \mathrm{F}$ for an additional 76,169 , or 351 days $(83,176$, or $358 *$ days total of curing). After 81,174 , or $356 *$ days of curing, the specimens were coated with epoxy. At the end of 82,175 , or $357 *$ days, the specimens were recoated with epoxy and sealed in copper. At 83,176 , or $358 *$ days, each coppersealed specimen was placed in a neoprene sleeve, sealed at both ends with neoprene cement and stainless steel bands,

*Depending on whether the specimens were to be loaded at 90,183 , or 365 days. 
and placed in the testing units. The testing units and specimens were then brought to testing temperature by placing them in the testing temperature environment for an additional seven days $(90,183$, or 365 days total of curing).

(b) $6 \times 12$-inch specimens

After 48 hours, the $6 \times 12$-inch specimens were submerged and cured in lime-saturated water at $75^{\circ} \mathrm{F}$ for five days (total of seven days of moist curing). Subsequent to this, the specimens were stored at 50 percent relative humidity at $75^{\circ} \mathrm{F}$ for the appropriate number of days. Specimens scheduled for testing at 183,365 , or 538 days after casting were sealed in copper 83 days after casting and were placed in the proper temperature environment until 24 hours prior to testing.

(3) Standard Cured Specimens

Only the $6 \times 12$-inch specimens were standard cured. After 48 hours, these specimens were submerged and cured in lime-saturated water at $75^{\circ} \mathrm{F}$ for either 26 days (ASTM C-192) or 88 days prior to testing.

LOADING AND TESTING

\section{Testing Temperature}

During the loading period, the concrete was subjected to one of two temperatures, $75^{\circ} \mathrm{F}$ or $150^{\circ} \mathrm{F}$. Environmental control units provided temperatures whlch were within $\pm 2^{\circ} \mathrm{F}$ of the desired temperatures and were recorded continuously. Relative humidity for the $75^{\circ} \mathrm{F}$ environment was maintained at $50 \pm 5$ percent. The relative humidity of the $150^{\circ} \mathrm{F}$ environment was not controlled since all specimens were sealed during the period of time they were subjected to this temperature.

\section{- Loading System}

The $6 \times 16$-inch specimens were loaded axially and radially with combinations of five different stress levels, ranging from 0 to 3600 psi, for both axial stress $\sigma_{a}$ and radial confining stress $\sigma_{r}$. Since the combination of stresses involved some zero stress levels, the loading conditions were classified as uniaxial, $\sigma_{\mathrm{r}}=0$; biaxial, $\sigma_{\mathrm{a}}=0$; and triaxial. The five stress levels involved were $0,600,1200,2400$, and 3600 psi nominal pressures. A schematic of the basic test unit is shown in Fig 4 while photographs of the actual units used to achieve these loading conditions are shown in Fig 5 . The shrinkage specimens are shown in Fig 6 . 


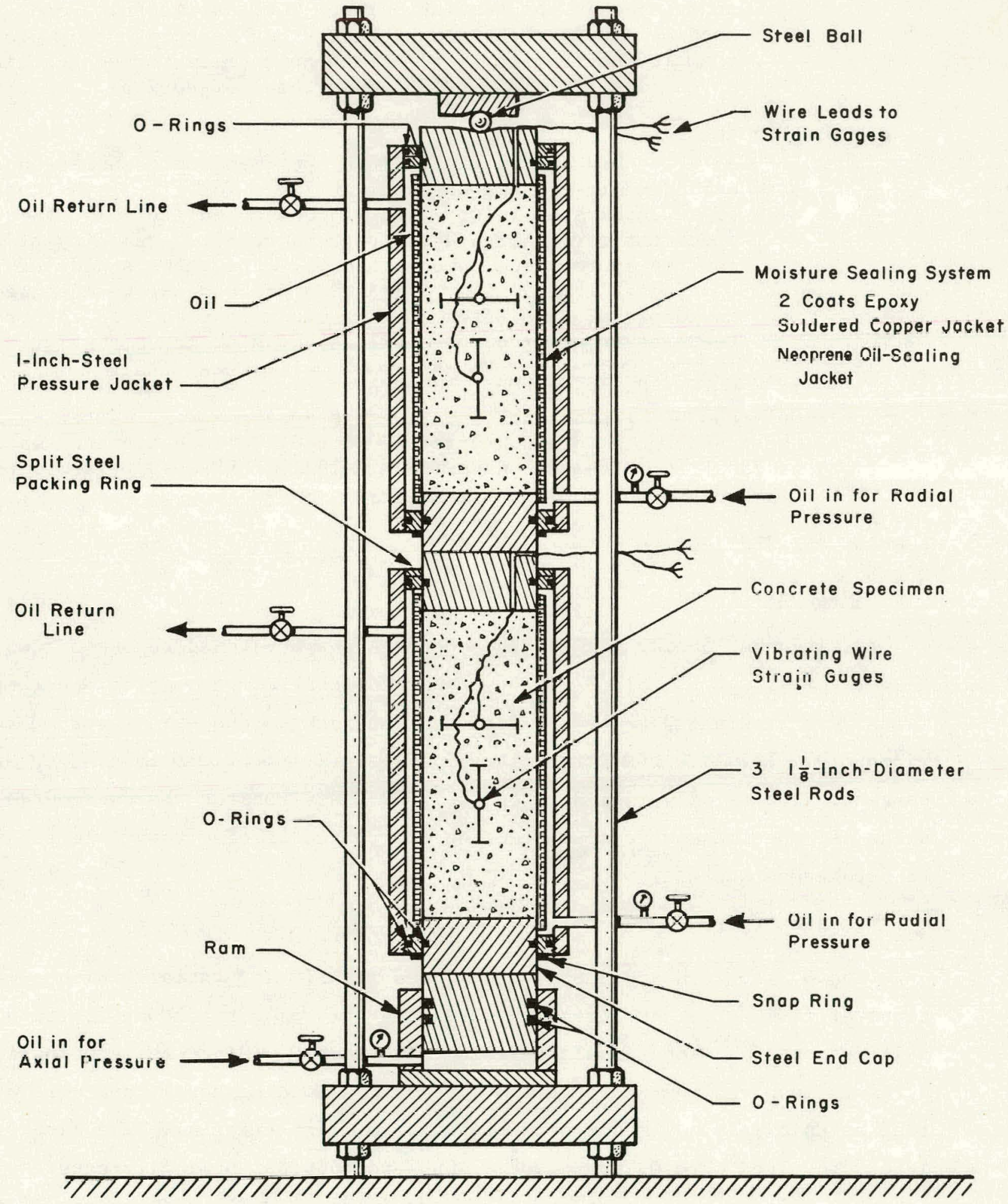

Fig 4. Schematic of triaxial test unit. 


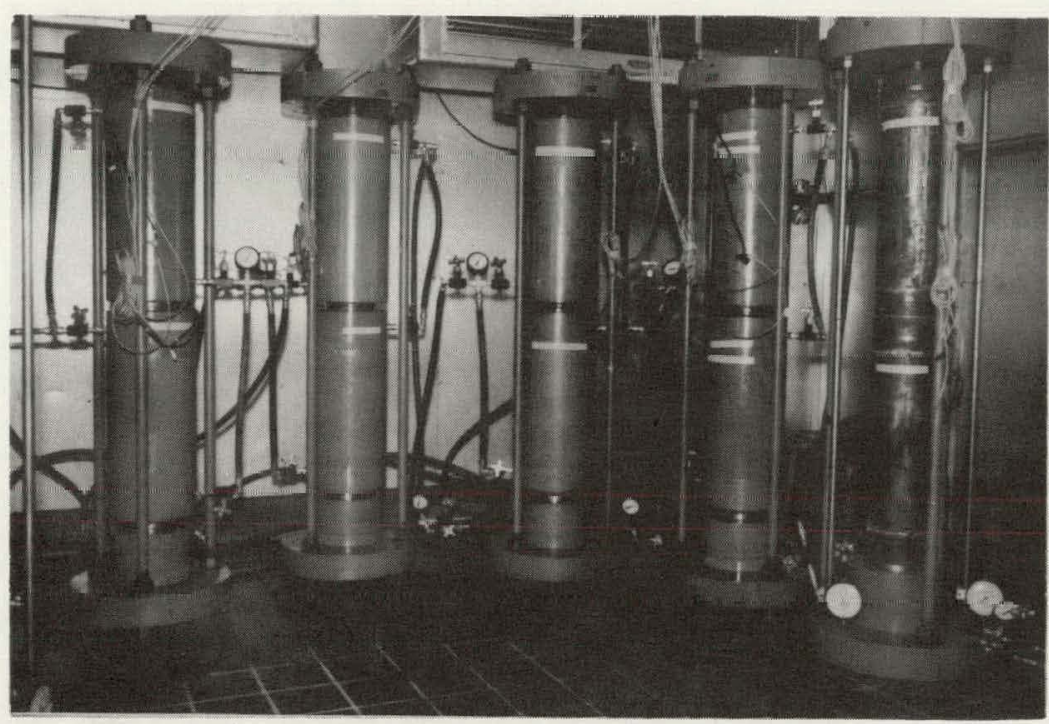

(a) Uniaxial and triaxial loading.

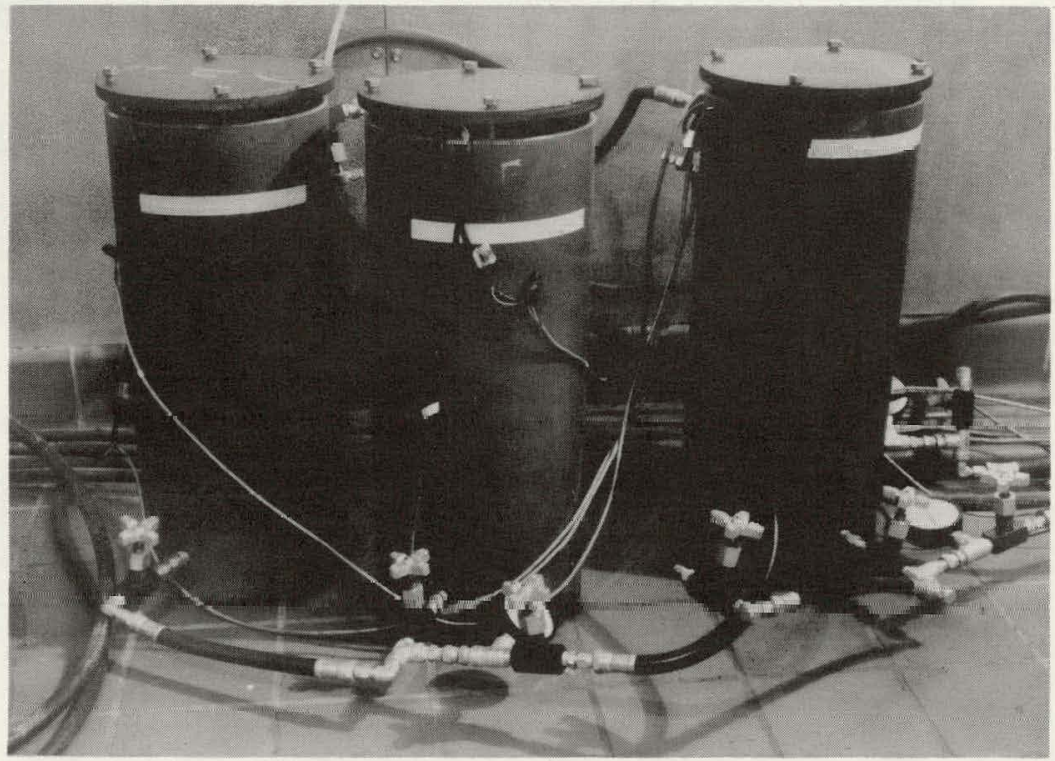

(b) Biaxial loading.

Fig 5. Test units. 


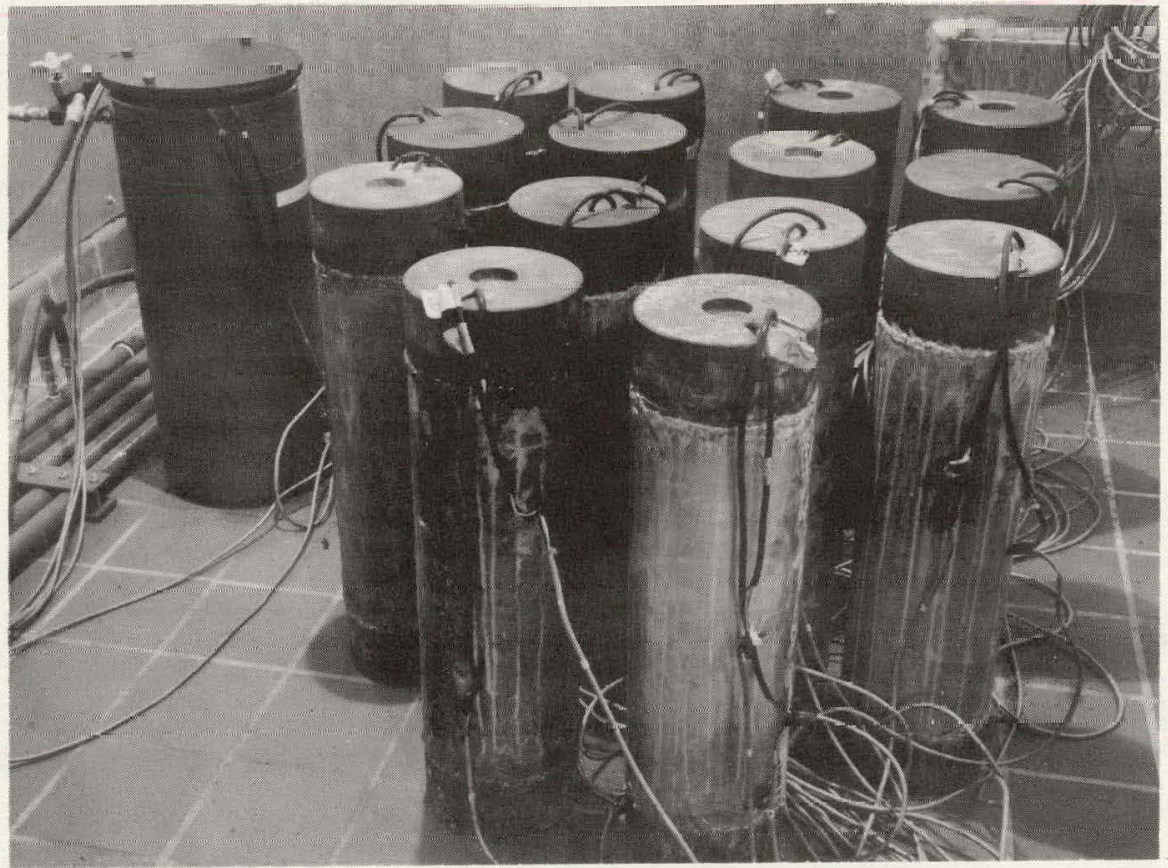

Fig 6. Shrinkage specimens and a biaxially-loaded specimen, 
The creep specimens were loaded 90, 183, or 365 days after casting. Prior to loading, the specimens were brought to temperature by placing them in their testing environment for a minimum of seven days. Each as-cast specimen was loaded simultaneously with its companion air-dried specimen. The higher of the two stress levels involved in each condition was applied at a rate of 35 psi per second, with the lower stress applied at a slower rate. In addition, the unconfined compressive and tensile strengths of specimens which had been subjected to the various environmental conditions were determined. The compressive strengths were determined at $28,90,183,365$, and 538 days after casting. Generally, three specimens for each curing history and age were tested from each batch. The tensile strengths were determined by the indirect tensile test, at 28 and 90 days; however, only two specimens for each curing history and age were tested. The compressive and tensile strength specimens were tested in accordance with ASTM specifications C39-66 and C496-69, respectively.

\section{STRAIN MEASUREMENTS}

Vibrating wire strain gages embedded in the creep and shrinkage specimens were read periodically during the curing period and loaded test period, according to the schedule contained in Appendix $\mathrm{E}$ of Ref 3 . These measurements involved both strain and temperature. The initial measurements were made according to the following procedure. Initial strain readings on the gages in the two specimens in each test unit were made in the following sequence at the times noted:

(1) Creep Specimens

(a) axial gage in as-cast specimen, 15 seconds after application of maximum load;

(b) radial gage in as-cast specimen, 30 seconds after application of maximum load;

. (c) axial gage in air-dried specimen, 45 seconds after application of maximum load; and

(d) radial gage in air-dried specimen, 60 seconds after application of maximum load.

(2) Shrinkage Specimens

(a) axial gage in as-cast specimen, 75 seconds after application of maximum load to creep specimens; 
(b) radial gage in as-cast specimen, 90 seconds after application of maximum load to creep specimens;

(c) axial gage in air-dried specimen, 105 seconds after application of maximum load to creep specimens; and

(d) radial gage in air-dried specimen, 120 seconds after application of maximum load to creep speciums.

After the strain readings had been made, the gages were read for temperature. Because of the many gage readings and operations which had to be performed to prepare, cure, and test the large number of specimens, a time flow diagram was prepared which indicated the time at which an operation or a gage reading had to be performed (Appendix $\mathrm{F}$ of Ref 3 ). In addition, a summary of operations and gage readings was prepared which listed all operations and gage readings, by specimen, which had to be performed each day (Appendix G of Ref 3 ). 
CHAPTER 3. SUMMARY AND EVALUATION OF FINDINGS

The majority of the findings of this study are contained in previous reports (Refs $1,2,4,5$, and 9) but are briefly summarized in this chapter.

\section{STRENGTH AND INSTANTANEOUS CHARACTERISTICS}

Compressive and Tensile Strengths

The average compressive and censile strengths for the nine batches of concrete are shown in Table 6 . The individual compressive and tensile strengths of the specimens are presented in Appendices $B$ and $C$ of Ref 11 and Appendix A of Ref 2 .

The average compressive strength of the standard cured specimens from all batches at 28 days was 6420 psi, which was within the design strength range of $6000 \pm 600 \mathrm{psi}$, and the average compressive strength at 90 days was 8220 psi. The air-dried specimens had a higher average compressive strength than the as-cast specimens up to 90 days after casting. Subsequent to this time, the as-cast specimens were stronger. The average tensile strength of specimens in all batches increased s1ightly with age.

\section{Instantaneous Strains and Elastic Properties}

The instantaneous, or elastic, strains due to the applied load were determined by taking readings just prior to loading and immediately after the maximum load had been applied. Since the four gages could not be read simultaneously, there was a delay in obtaining some of the readings. The instantaneous strains were estimated by extrapolating the strain-time relationships to obtain the strains at time zero.

The modulus of elasticity for specimens cured for 90 days ranged from $4.00 \times 10^{6}$ to $7.10 \times 10^{6} \mathrm{psi}$ and averaged $5.50 \times 10^{6} \mathrm{psi}$. The average moduli of elasticity for the as-cast and air-dried specimens loaded at $75^{\circ} \mathrm{F}$ were $5.86 \times 10^{6}$ and $5.50 \times 10^{6} \mathrm{psi}$, respectively. Specimens loaded at $150^{\circ} \mathrm{F} \mathrm{had}$ lower moduli, with the average values for the as-cast and air-dried specimens 
TA3LE 6. AVERAGE CCMPRESSIVE AND TENSILE STRENGTHS

\begin{tabular}{|c|c|c|c|c|c|c|c|c|c|c|c|c|c|}
\hline & \multirow{2}{*}{$\begin{array}{l}\text { Age of } \\
\text { Testing, } \\
\text { doys }\end{array}$} & \multirow{2}{*}{$\begin{array}{l}\text { Curing } \\
\text { Conditions }\end{array}$} & \multirow{2}{*}{ Temperatura, } & \multicolumn{9}{|c|}{ Average Strengths of Batches, psi } & \multirow{2}{*}{$\begin{array}{c}\text { Avg Strengths } \\
\text { of al1 Batches } \\
\text { psi }\end{array}$} \\
\hline & & & & A & B & C & $\mathrm{D}$ & $\mathrm{E}$ & $\mathrm{F}$ & G & $\mathrm{H}$ & $\mathrm{I}$ & \\
\hline \multirow{9}{*}{$\begin{array}{l}0 \\
0 \\
-1 \\
0 \\
0 \\
0 \\
\Delta \\
0 \\
0 \\
0 \\
0\end{array}$} & $\stackrel{\infty}{\sim}$ & $\begin{array}{l}\text { Standard } \\
\text { As-Cast } \\
\text { Air-Dried }\end{array}$ & 75 & $\begin{array}{l}6760 \\
6580 \\
7060 \\
\end{array}$ & $\begin{array}{l}6650 \\
4710 \\
6200 \\
\end{array}$ & $\begin{array}{l}6140 \\
5700 \\
6520 \\
\end{array}$ & $\begin{array}{l}6200 \\
5980 \\
6640 \\
\end{array}$ & $\begin{array}{l}6520 \\
5410 \\
6540 \\
\end{array}$ & $\begin{array}{l}6510 \\
5650 \\
6680 \\
\end{array}$ & $\begin{array}{l}64 \div 0 \\
59.40 \\
6570 \\
\end{array}$ & $\begin{array}{l}6340 \\
5650 \\
6320 \\
\end{array}$ & $\begin{array}{l}6260 \\
5790 \\
6440 \\
\end{array}$ & $\begin{array}{l}6420 \\
5710 \\
6550 \\
\end{array}$ \\
\hline & ○ & $\begin{array}{l}\text { Standard } \\
\text { As-Cast } \\
\text { Air-Dried }\end{array}$ & 75 & $\begin{array}{l}8550 \\
6880 \\
6960 \\
\end{array}$ & $\begin{array}{l}8690 \\
6110 \\
1790 \\
\end{array}$ & $\begin{array}{l}8290 * \\
6430 * \\
7370 *\end{array}$ & $\begin{array}{l}8540 \\
6500 \\
7790 \\
\end{array}$ & $\begin{array}{l}8200 \\
7290 \\
7420 \\
\end{array}$ & $\begin{array}{l}8090 \\
7410 \\
7870 \\
\end{array}$ & $\begin{array}{l}77300 \\
7450 \\
7450 \\
\end{array}$ & $\begin{array}{l}8110 \\
6330 \\
7280 \\
\end{array}$ & $\begin{array}{l}7870 \\
6160 \\
7060 \\
\end{array}$ & $\begin{array}{l}8220 \\
6640 \\
7450 \\
\end{array}$ \\
\hline & \multirow{2}{*}{$\underset{\infty}{\infty}$} & As-Cast & $\begin{array}{r}75 \\
150 \\
\end{array}$ & $\begin{array}{l}8260 \\
8120 \\
\end{array}$ & - & $\begin{array}{l}- \\
- \\
\end{array}$ & $\begin{array}{l}- \\
-\end{array}$ & $\begin{array}{l}- \\
- \\
\end{array}$ & - & $\begin{array}{l}76: 0 \\
82.30 \\
\end{array}$ & $\begin{array}{c}7660 \\
- \\
\end{array}$ & $\begin{array}{l}6960 \\
7730 \\
\end{array}$ & $\begin{array}{l}7630 \\
8040 \\
\end{array}$ \\
\hline & & Air-Dried & $\begin{array}{r}75 \\
150 \\
\end{array}$ & $\begin{array}{l}7030 \\
7760 \\
\end{array}$ & - & - & - & - & - & $\begin{array}{l}7310 \\
7100\end{array}$ & $\begin{array}{c}7470 \\
- \\
\end{array}$ & $\begin{array}{l}7200 \\
6960 \\
\end{array}$ & $\begin{array}{l}7250 \\
7270 \\
\end{array}$ \\
\hline & \multirow{2}{*}{ in } & As-Cast & $\begin{array}{r}75 \\
150 \\
\end{array}$ & $\begin{array}{l}8840 \\
7600 \\
\end{array}$ & - & - & - & - & - & $\begin{array}{l}8190 \\
8310\end{array}$ & $\begin{array}{c}6330 \\
-\end{array}$ & $\begin{array}{l}7340 \\
7660\end{array}$ & $\begin{array}{l}7830 \\
7860\end{array}$ \\
\hline & & Air-Dried & $\begin{array}{r}75 \\
150 \\
\end{array}$ & $\begin{array}{l}7480 \\
7010 \\
\end{array}$ & - & - & - & $\begin{array}{l}-1 \\
-\end{array}$ & - & $\begin{array}{l}7810 \\
7850\end{array}$ & $\begin{array}{c}6.360 \\
-\end{array}$ & $\begin{array}{l}7590 \\
7170\end{array}$ & $\begin{array}{l}7440 \\
7350\end{array}$ \\
\hline & \multirow{3}{*}{$\stackrel{\infty}{m}$} & & 75 & 8430 & - & - & - & - & - & 9010 & $\overline{1530}$ & $\overline{7170}$ & 8040 \\
\hline & & As-cas & 150 & 9130 & - & - & 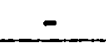 & - & - & $82>0$ & - & 7470 & 8290 \\
\hline & & Air-Dried & $\begin{array}{r}75 \\
150 \\
\end{array}$ & $\begin{array}{l}8570 \\
7940\end{array}$ & $\begin{array}{l}- \\
- \\
\end{array}$ & $\begin{array}{l}- \\
-\end{array}$ & $\begin{array}{l}- \\
-\end{array}$ & - & - & $\begin{array}{l}80 ? 0 \\
7550 \\
\end{array}$ & $\begin{array}{c}7550 \\
- \\
\end{array}$ & $\begin{array}{l}7470 \\
7860 \\
\end{array}$ & $\begin{array}{l}7920 \\
7780 \\
\end{array}$ \\
\hline \multirow{4}{*}{ 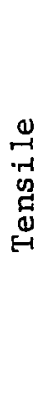 } & $\stackrel{\infty}{\sim}$ & $\begin{array}{l}\text { Standard } \\
\text { As-Cast } \\
\text { Air-Dried }\end{array}$ & 75. & $\begin{array}{l}- \\
- \\
- \\
\end{array}$ & $\begin{array}{l}630 * x \\
- \\
560 \div \div\end{array}$ & $\begin{array}{l}580 \\
- \\
- \\
\end{array}$ & $\begin{array}{l}620 \\
520 \\
530 \\
\end{array}$ & $\begin{array}{l}570 \\
- \\
- \\
\end{array}$ & $\begin{array}{l}550 \\
-- \\
- \\
\end{array}$ & $\begin{array}{l}- \\
- \\
- \\
\end{array}$ & $\begin{array}{l}- \\
- \\
\end{array}$ & $\begin{array}{l}- \\
- \\
-\end{array}$ & $\begin{array}{l}590 \\
- \\
- \\
\end{array}$ \\
\hline & ᄋ̊ & $\begin{array}{l}\text { Standard } \\
\text { As-Cast } \\
\text { Air-Dried }\end{array}$ & 75 & $\begin{array}{l}- \\
- \\
-\end{array}$ & $\begin{array}{l}540 \\
5510 \\
540 \\
\end{array}$ & $\begin{array}{l}680 \\
610 \\
580 \\
\end{array}$ & $\begin{array}{l}510 \\
530 \\
550 \\
\end{array}$ & $\begin{array}{l}710 \\
590 \\
550 \\
\end{array}$ & $\begin{array}{l}690 \\
590 \\
580 \\
\end{array}$ & $\begin{array}{l}- \\
- \\
-\end{array}$ & $\begin{array}{l}- \\
- \\
-\end{array}$ & $\begin{array}{l}- \\
- \\
\end{array}$ & $\begin{array}{l}630 \\
570 \\
560 \\
\end{array}$ \\
\hline & \multirow{2}{*}{$\stackrel{\infty}{\prod_{n}}$} & As-Cast & $\begin{array}{r}75 \\
150 \\
\end{array}$ & - & $\begin{array}{l}600 \\
600 \\
\end{array}$ & $\begin{array}{l}590 \\
550 \\
\end{array}$ & $\begin{array}{l}- \\
-\end{array}$ & $\begin{array}{l}550 \\
620 \\
\end{array}$ & $\begin{array}{l}490 \\
610 \\
\end{array}$ & - & - & - & $\begin{array}{l}560 \\
600 \\
\end{array}$ \\
\hline & & Air-Dried & $\begin{array}{r}75 \\
150\end{array}$ & - & $\begin{array}{l}7610 \\
6610\end{array}$ & $\begin{array}{l}740 \\
580\end{array}$ & - & $\begin{array}{l}650 \\
610\end{array}$ & $\begin{array}{l}690 \\
660\end{array}$ & - & - & - & $\begin{array}{l}710 \\
630\end{array}$ \\
\hline
\end{tabular}

* Batch C tested at 83 days.

'x* only one sample used. 
being $5.74 \times 10^{6} \mathrm{psi}$ and $4.87 \times 10^{6} \mathrm{psi}$. Poisson's ratio ranged from 0.21 to 0.29 and averaged 0.25 .

A comparison of the above properties for specimens cured for 90 days and subjected to comparable test conditions is shown in Table 7. It was found that (1) the air-dried specimens had slightly lower moduli of elasticity than the as-cast specimens; (2) the specimens loaded at $150^{\circ} \mathrm{F}$ had slightly lower moduli than the specimens loaded at $75^{\circ} \mathrm{F}$; and (3) Poisson's ratio was. not significantly affected by curing history and testing temperature.

The moduli of elasticity and Poisson's ratios for the 8 specimens cured for either 183 or 365 days and the corresponding specimens cured for 90 days are shown in Table 8. From this table it would appear that the magnitude of the modulus of elasticity and Poisson's ratio were not affected by the length of curing time prior to loading nor by the curing history although there was a slight increase of modulus with time and a slight decrease of Poisson's ratio. The average modulus of elasticity and Poisson's ratio were $6.03 \times 10^{6} \mathrm{psi}$ and 0.25 , respectively, which were essentially equal to the average values obtained for the 90-day creep specimens.

\section{SHRINKAGE STRAINS}

To determine creep strains it was necessary to measure shrinkage during the curing, creep, and recovery periods.

\section{Shrinkage During Curing}

Estimates of the relationships between shrinkage strain and time for the as-cast and air-dried specimens during the 90-day curing period were obtained by averaging the shrinkage strains in both the shrinkage and creep specimens from Batches A through $G$ (Fig 7). In these relationships the seven-day reading was considered as the initial reference point, since the curing and handling procedures during the first seven days were different.

The average axial and radial strains of the as-cast specimens, which did not experience a significant loss of moisture during the curing period (Tables 9 and 10), were essentially zero throughout the curing period (Fig $7 a$ ). The average compressive strains of the air-dried specimens, however, continued to increase (Fig 7b) throughout the curing period and the specimens exhibited a substantial loss of moisture during the first 82 days, at the end of which 
TABLE 7. MODULUS OF ELASTIC_TY AND POISSON'S RATIO RESULTS FOR SPECIMEIS CURED FOR 90 DAYS

\begin{tabular}{|c|c|c|c|c|c|c|c|}
\hline \multirow{2}{*}{\multicolumn{2}{|c|}{ Stress, psi }} & \multicolumn{3}{|c|}{$75^{\circ} \mathrm{F}$ As-Cast } & \multicolumn{3}{|c|}{$75^{\circ} \mathrm{E}$ Air-Dried } \\
\hline & & \multirow[b]{2}{*}{ Specimen } & \multirow{2}{*}{$\begin{array}{c}\text { Poisson's } \\
\text { Ratic }\end{array}$} & \multirow{2}{*}{$\begin{array}{c}\text { Mcdulus of } \\
\text { Elasticity, } \\
10^{6} \text { psi }\end{array}$} & \multirow[b]{2}{*}{ Specimen } & \multirow{2}{*}{$\begin{array}{l}\text { Poisson's } \\
\text { Ratio. }\end{array}$} & \multirow{2}{*}{$\begin{array}{c}\text { Modulus of } \\
\text { Elasticity, } \\
10^{6} \text { psi }\end{array}$} \\
\hline Axial: & Radial & & & & & & \\
\hline 600 & 0 & $E-39$ & 0.29 & 6.04 & $E-40$ & 0.2 .3 & 5.64 \\
\hline 2400 & 0 & $\mathrm{~B}-7$ & 0.24 & 5.66 & $B-19$ & 0.27 & 5.76 \\
\hline 2400 & 600 & $C-23$ & 0.24 & 6.54 & . $C-11$ & 0.25 & 5.51 \\
\hline 0 & 600 & $F-13$ & 0.26 & 6.13 & $F-42$ & 0.25 & 5.98 \\
\hline 0 & 3600 & $\mathrm{H}-22$ & 0.21 & 4.51 & H- 14 & 0.23 & 4.85 \\
\hline \multirow{2}{*}{\multicolumn{2}{|c|}{ Average }} & & 0.25 & \multirow[t]{2}{*}{5.78} & \multicolumn{2}{|r|}{0.25} & 5.55 \\
\hline & & \multicolumn{2}{|c|}{$150^{\circ} \mathrm{F}$ As-Cast. } & & \multicolumn{3}{|c|}{$150^{\circ} \mathrm{F}$ Air-Dried } \\
\hline 600 & 0 & $B-4$ & 0.24 & 5.94 & B- 1 & 0.25 & 5.49 \\
\hline 2400 & 0 . & $F-33$ & 0.26 & 5.15 & F- 34 & 0.26 & 4.53 \\
\hline 2400 & 600 & $E-18$ & 0.22 & 6.19 & $E-4$ & C.24 & 5.23 \\
\hline 0 & 600 & $A-35$ & 0.25 & 6.35 & $I-13$ & C. .24 & 5.28 \\
\hline 0 & 3600 & $I-16$ & 0.24 & 4.97 & $I-30$ & C. .23 & 4.40 \\
\hline \multicolumn{3}{|l|}{ Average } & 0.24 & 5.72 & & 0.24 & 4.99 \\
\hline
\end{tabular}

*Nominal axial stress. 
TABLE 8. INS TANTANEOUS MODULUS OF ELASTICITY AND POISSON'S RATIO FOR SPECIMENS WITH VARIOUS CURING TIMES AND HISTORIES

Instantaneous Modulus of Elasticity, $10^{6} \mathrm{psi}$

\begin{tabular}{|c|c|c|c|c|c|c|}
\hline \multirow{3}{*}{$\begin{array}{c}\text { Stress, } \\
\text { psi }\end{array}$} & \multicolumn{6}{|c|}{ Curing Time and History } \\
\hline & \multicolumn{2}{|c|}{$90 \cdot$ Days } & \multicolumn{2}{|c|}{1.83 Days } & \multicolumn{2}{|c|}{365 Days } \\
\hline & As-Cast & Air-Dried & As-Cast & Air-Dried & As-Cast & Air-Dried \\
\hline 600 & 6.24 & 5.83 & 5.99 & 7.04 & 7.39 & 5.46 \\
\hline \multirow[t]{2}{*}{2400} & 5.67 & 5.77 & 5.67 & 5.66 & 6.66 & .4 .95 \\
\hline & 5.95 & 5.80 & 5.83 & 6.35 & 7.02 & 5.20 \\
\hline Average & \multicolumn{2}{|c|}{5.87} & \multicolumn{2}{|c|}{6.09} & \multicolumn{2}{|c|}{6.10} \\
\hline
\end{tabular}

Tnstantanenus Pnissnn's Ratio

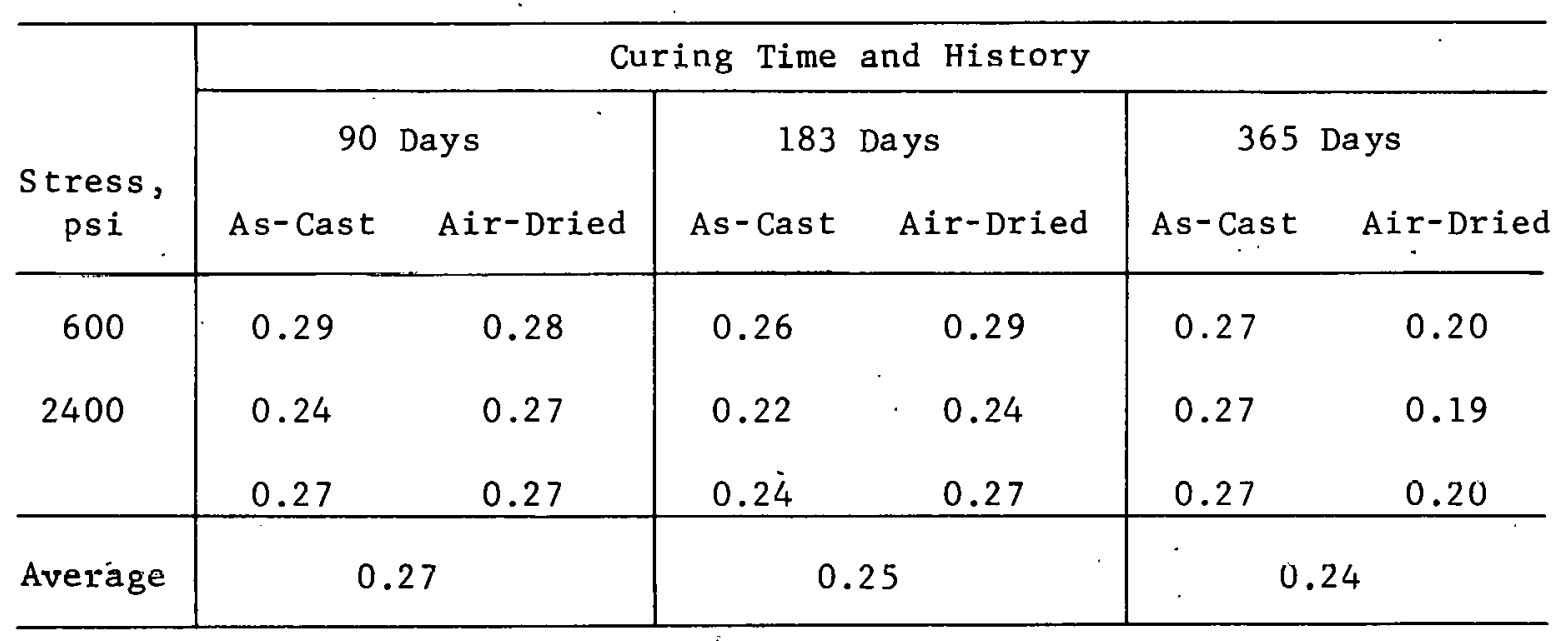




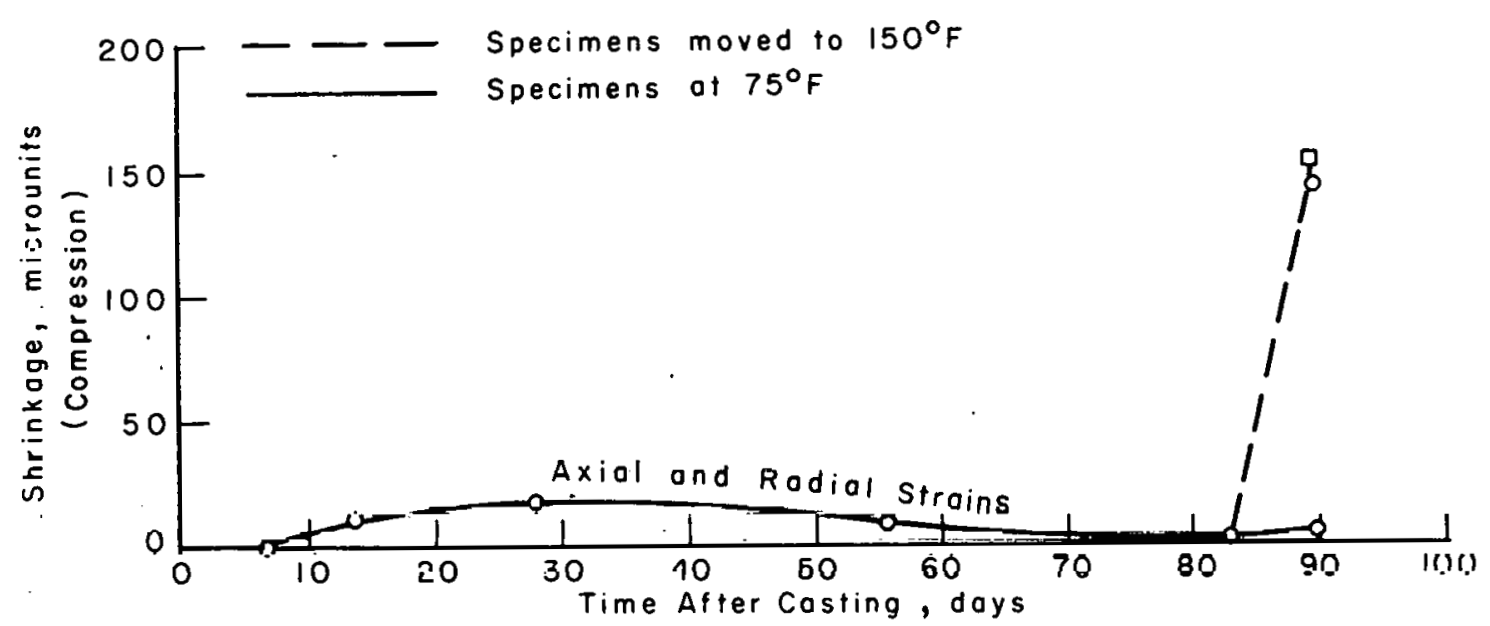

(a) As-cast specimens.

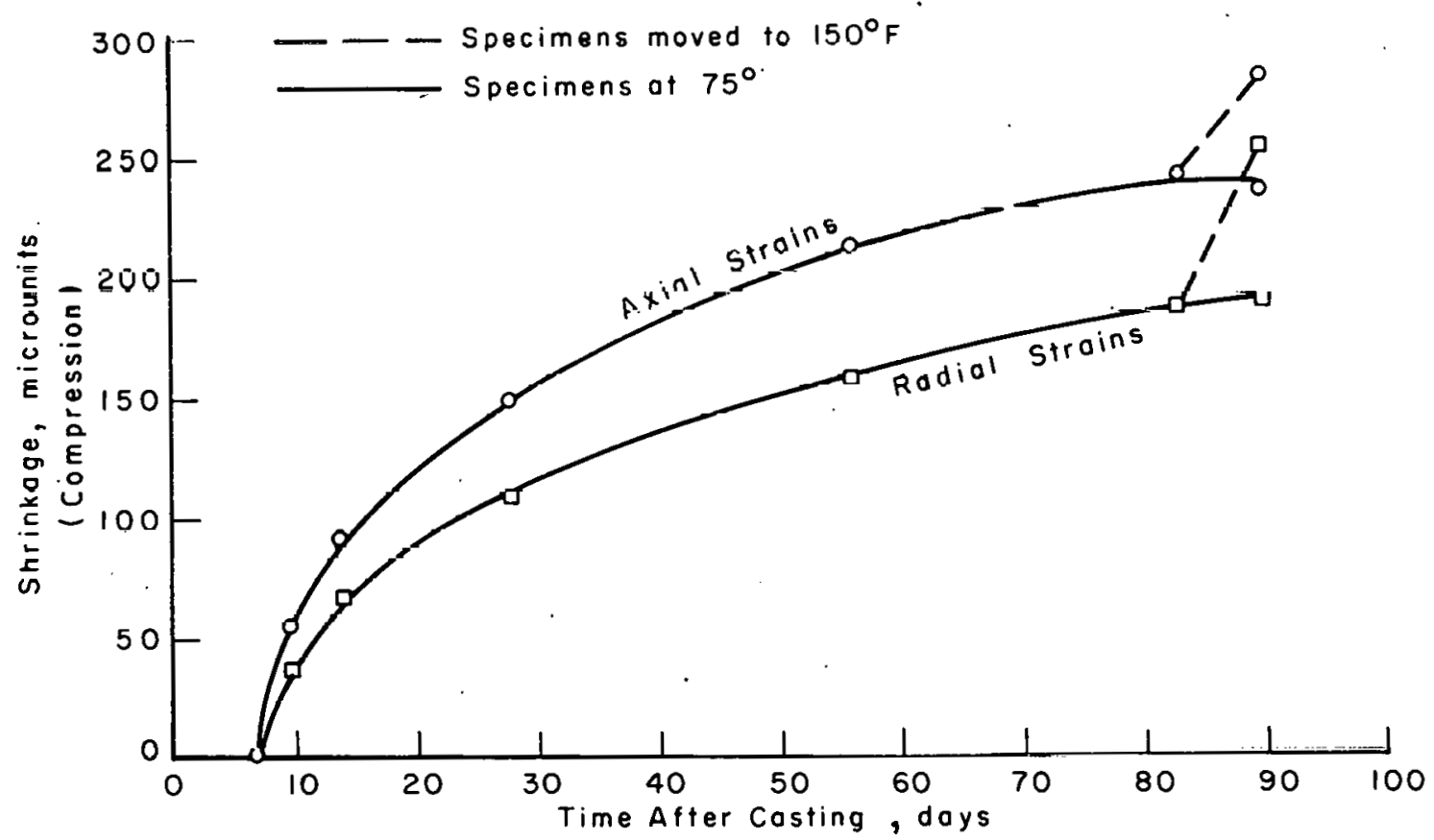

(b) Air-tried specimens.

Fig 7. Average shrinkage strains for as-cast and air-dried specimens during the 90-day curing period. 
TABLE 9. GAGE PERFORMANCE AND WEIGHT CHANGES OF SHRINKAGE SPECIMENS

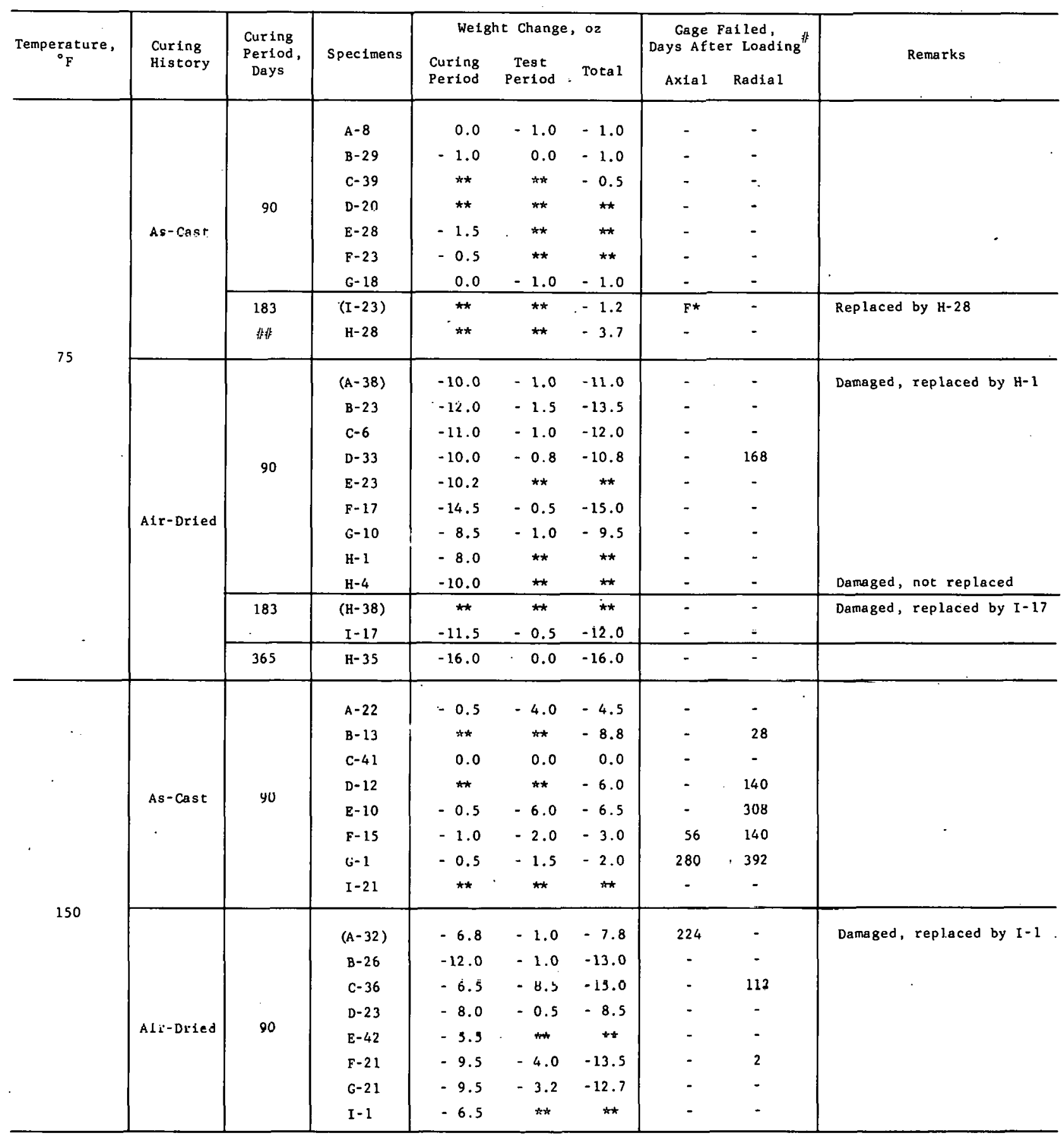

*Failed 7 days after casting.

* I. nformation not obtalned.

\#Refers to day after loading of companion creep specimens.

\#非 Served as a shrinkage specimen for creep spec1mens cured for 90, 183, and 365 days. 
TABLE 10. AVERAGE WEIGHT CHANGES OF ALL SPECIMENS DURIN

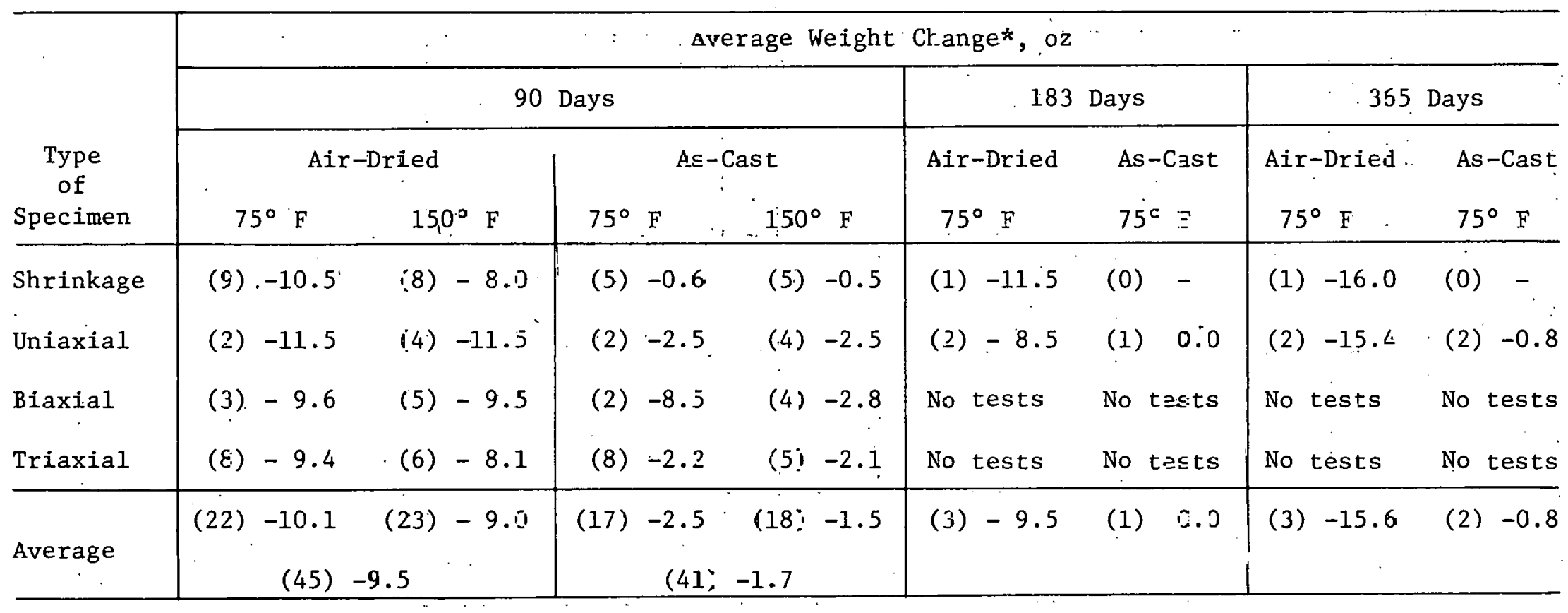

*Numbers in parentheses are the number of specimens for which information was available. 
they were sealed in copper. At that time, the average axial and radial shrinkage strains for the air-dried specimens were approximately 240 and 190 microunits, respectively, and the average moisture loss. was 9.5 ounces (Table 10). After sealing, the strains began to converge and become essentially equal and constant. The apparent increase in strains between 83: and 90 days for as-cast and air-dried specimens subjected to $150^{\circ} \mathrm{F}$ was due to a difference in thermal characteristics of the gage and concrete, which is discussed under gage performance (Chapter 4) and in more detail in Ref 11.

\section{Shrinkage During Testing of 90-Day Specimens}

Shrinkage strains were measured during the loading period so that creep strain could be estimated by separating the total time-dependent strain into that due to moisture loss and that due to load. Average shrinkage curves for the as-cast and air-dried shrinkage specimens from Batches $A$ through $G$ are shown in Fig 8 .

Essentially no shrinkage occurred in the as-cast specimens (Fig 8a) at $75^{\circ} \mathrm{F}$; however, at $150^{\circ} \mathrm{F}$.the specimens exhibited expansion rather than shrinkage. Most of this expansion occurred during the first 84 days of the loading period, at the end of which the axial and radial gages indicated tensile strains of 33 and 37 microunits, respectively. During the remainder of the loading period, very little additional strain was detected. The shrinkage behavior associated with specimens subjected to the $150^{\circ} \mathrm{F}$ temperature is partially attributed to thermal incompatability between the concrete and the gage.

The rate of axial and radial shrinkage in the air-dried specimens at $75^{\circ} \mathrm{F}$ (Fig 8b). decreased throughout the entire" testing period. However, the radia1 strains were compressive, indicating shrinkage, while the axial strains were tensile, indicating expansion. Nevertheless, the magnitudes of the strains after 12 months were relatively small, with the axial gage indicating 34 microunies expansion and the radial gage 18 microunits shrinkage.

The shrinkage strain relationships for the air-dried specimens at $150^{\circ} \dot{F}$ were similar to those for the as-cast specimens at the same temperature, although the strains were greater. These specimens expanded continuously at a decreasing rate. At the end of the 12 -month period the axial and radial strains were 67 and 53 microunits expansion, respectively. 


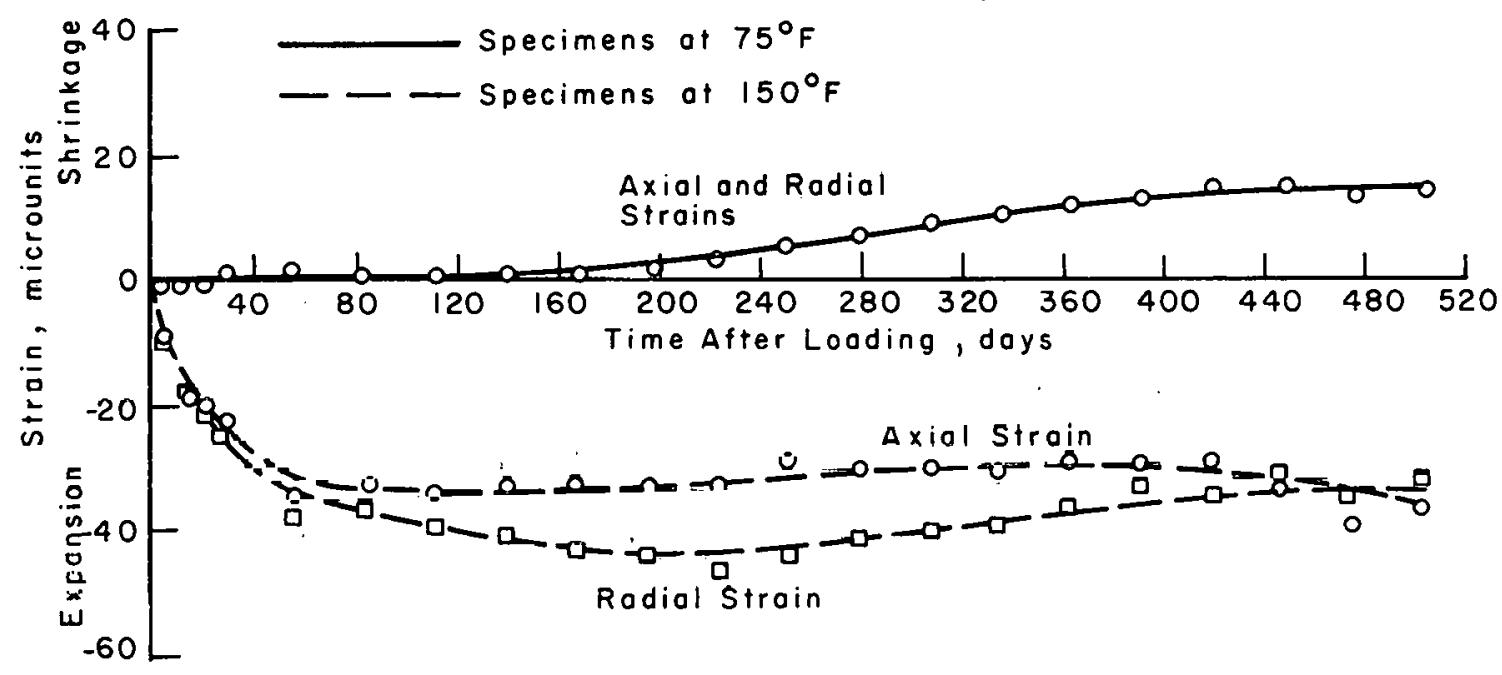

(a) As-cast specimens.

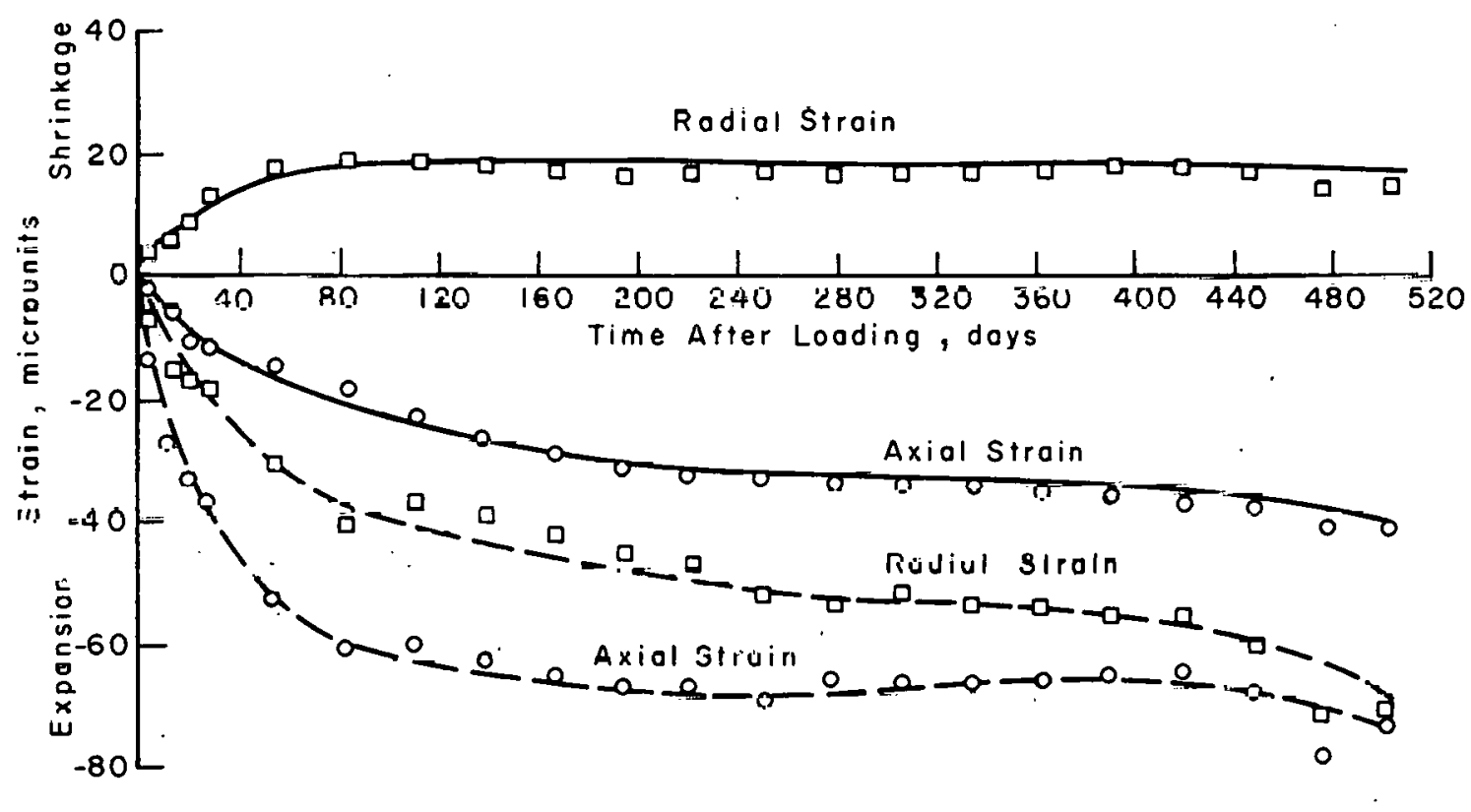

(b) Aix-dried specimens.

Fig 8. Average shrinkage strains during the loaded and unloaded periods for specimens loaded at 90 days. 
Shrinkage During Loading Period of 183 and 365-Day Specimens

The strain-time relationships for the shrinkage specimens associated with the 183-day and 365-day creep specimens are shown in Figs 9 and 10. Specimen H-28 served as the shrinkage specimen for both the 183-day and 365-day creep specimens. This specimen appeared to shrink at an increased rate approximately 400 days after casting, although the weight of the specimen at the end of the test period indicated a weight loss of only 3.7 ounces, which is insignificant in comparison with losses of other as-cast specimens. In the portion of the experiment devoted to the evaluation of the creep:behavior of concrece cured 90 days prior to loading, the as-cast shrinkage specimens at $75^{\circ} \mathrm{F}$ exhibited very little shrinkage strain during the entire creep (loaded) and recovery (unloaded) periods (Fig 8a). Based on these observations, a shrinkage curve was constructed to replace the measured curve for specimen $\mathrm{H}-28$ by extrapolating the shrinkage strain-time relationship prior to about 400 days after casting and assuming that essentially no additional moisture was lost. The curves are shown as dashed lines on Figs 9 and 10 .

Another difference between the behavior of the shrinkage specimens in this portion of the experiment and those used in the portion involving a 90-day curing period is the fact that the radial strains for the air-dried specimens (I-17 and H-35) indicated expansion, while previously the average radial relationship indicated shrinkage. Although these two specimens did not have a significant loss of moisture during the test period, they did lose a substantial amount during the curing period (Table 9).

Thus, the shrinkage data are inconclusive and additional tests would be required to determine shrinkage. Nevertheless, the influence of shrinkage on the creep behavior of specimens subjected to a uniaxial stress of $2400 \mathrm{psi}$ is probably small, since the strains resulting from this loading are relatively large. Ilowever, the error will have a significant effect on the estimated creep behavior on the specimens loaded with a 600 psi uniaxial stress. Therefore, in the evaluation of the long-term creep behavior emphasis was placed on the creep information obtained from the specimens subjected to a stress of 2400 psi.

TOTAL STRAINS IN STRESSED SPECIMENS

All strain-time data and curves for the axial-and radial strains for the 


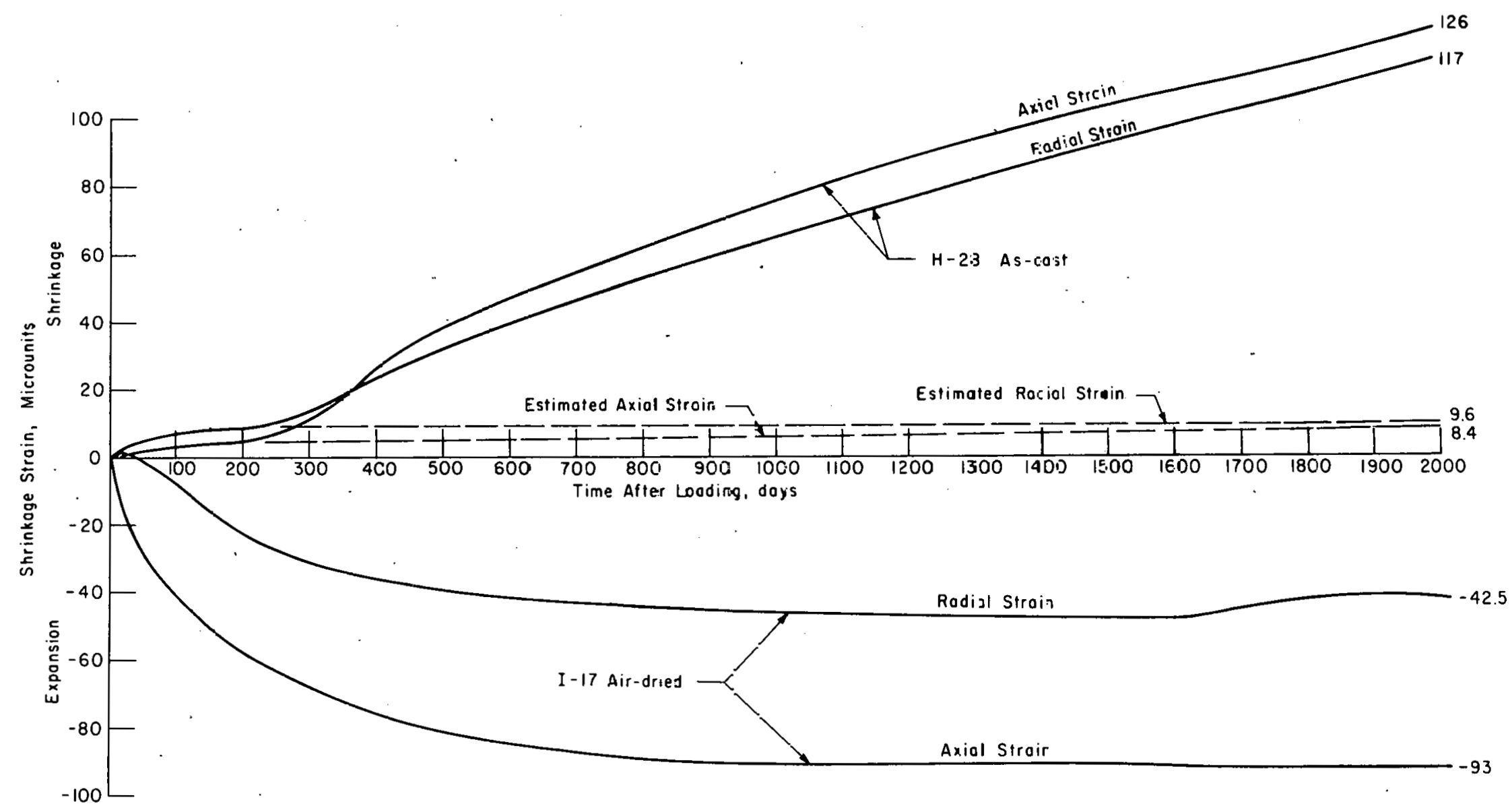

Fig 9. Shrinkage strains during the loadec and tnloaded periods for creef specimens cured 183 days. 


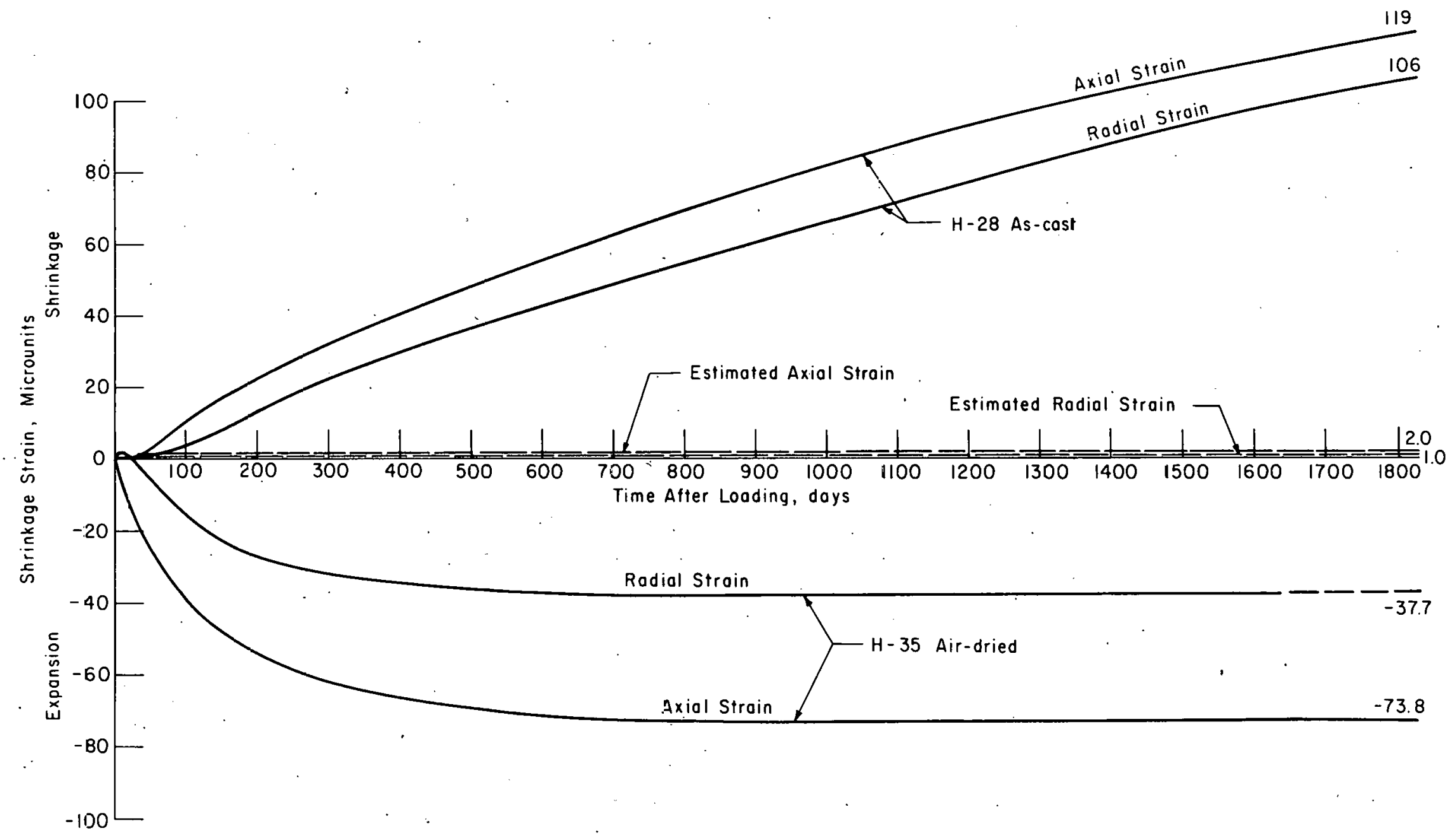

Fig 10. Shrinkage strains durirg the loaded and unloaded periods for creep specimens cured 365 days. 
specimens loaded at 90 days are presented in Ref 11. The relationships for the specimens loaded 183 or 365 days after casting are shown in Appendix A of this report. The total strain includes the elastic strains upon application of load and the time-dependent shrinkage and creep strains. A qualitative review of these data indicated that

(1) an increase in stress produced larger total strains and strain rates,

(2) specimens loaded triaxially at a stress ratio approximately equal to Puissun's ratio exhibited littlc, if any, strain in the minor stress dirertion,

(3) in triaxially loaded specimens, for a glven principal stress, an increase in stress in a plane perpendicular to the principal stress reduced the strain along the axis of the principal stress,

(4) under hydrostatic states of stress compressive strain occurred in all three principal directions, indicating volumetric creep occurred with time,

(5) the total strain and strain rate for air-dried specimens were significantly larger than for as-cast specimens,

(6) the total strain and strain rate were larger for specimens at $150^{\circ} \mathrm{F}$ than for specimens at $75^{\circ} \mathrm{F}$, and

(7) for comparable states of stress, within the limits of this experiment the order of increased total strain with time was $75^{\circ} \mathrm{F}$, as-cast; $75^{\circ} \mathrm{F}$, air-dried; $150^{\circ} \mathrm{F}$, as-cast; and $150^{\circ} \mathrm{F}$, air-dried.

CREEP STRAINS AND BEHAVIOR

Creep strains were estimated by subtracting the instantaneous and shrinkage strains from the total. Thus, it was assumed that the instantaneous elastic strain for each specimen was constant and did not vary with time and that the time-dependent strains, i.e., shrinkage and creep, were not interrelated. The creep strain-time relationships for the specimens loaded at 90 days are shown in Appendix $A$ of Ref 1 and the data are summarized in Appendix $G$ of Ref 11 . The relationships for the specimens loaded at 183 and 365 days, along with comparable relationships for 90-day specimens, are shown in Figs 11 through 14. The creep rate was much larger during the early portion of the loading period, but, approximately three months after loading, the creep strain became relatively constant and no significant change occurred during the remaining portion of the loaded period. 


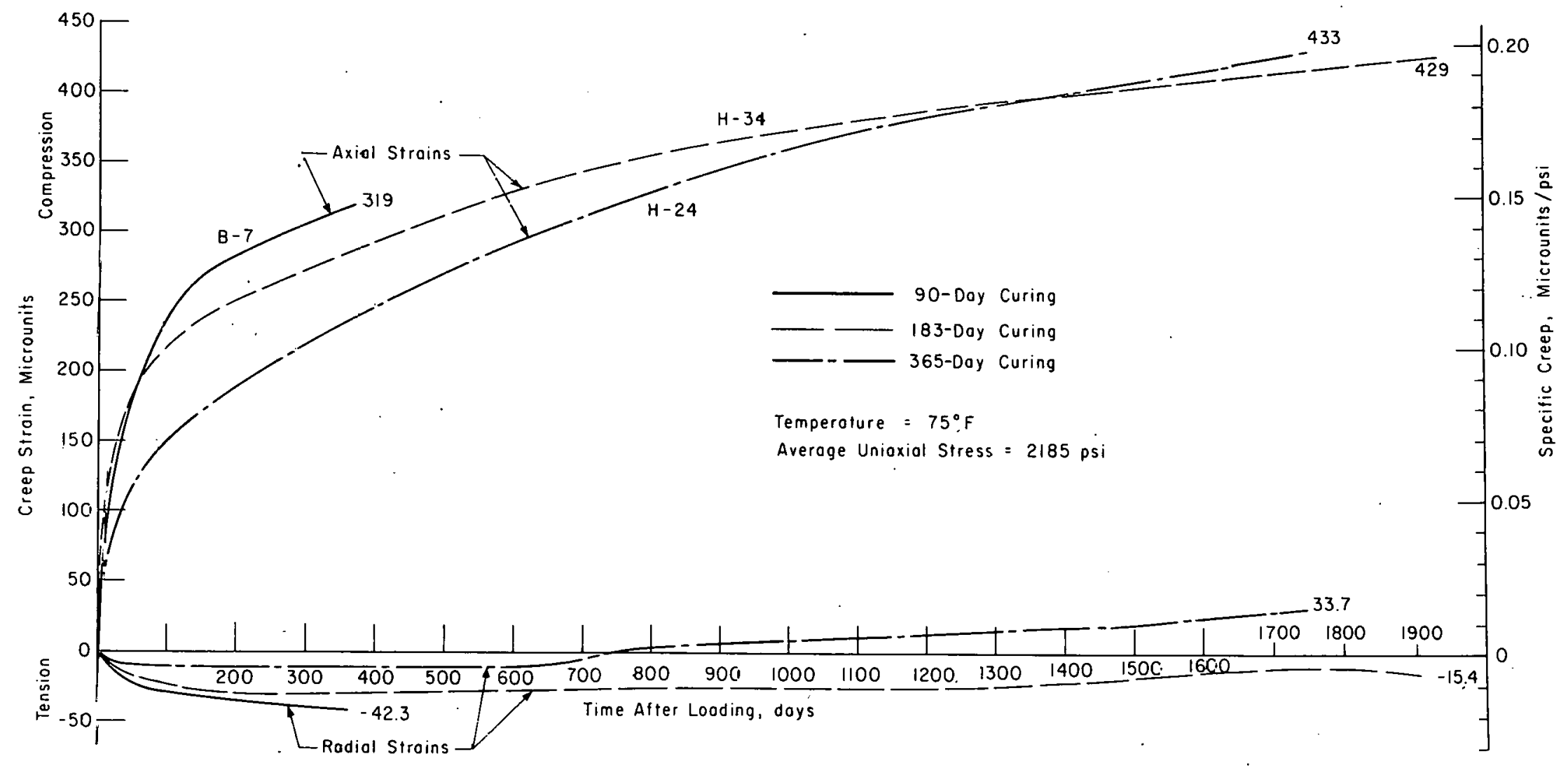

Fig 11. Axial and radial creep strain relationships for as-cast specimens with uniaxial stress of 2400 psi. 


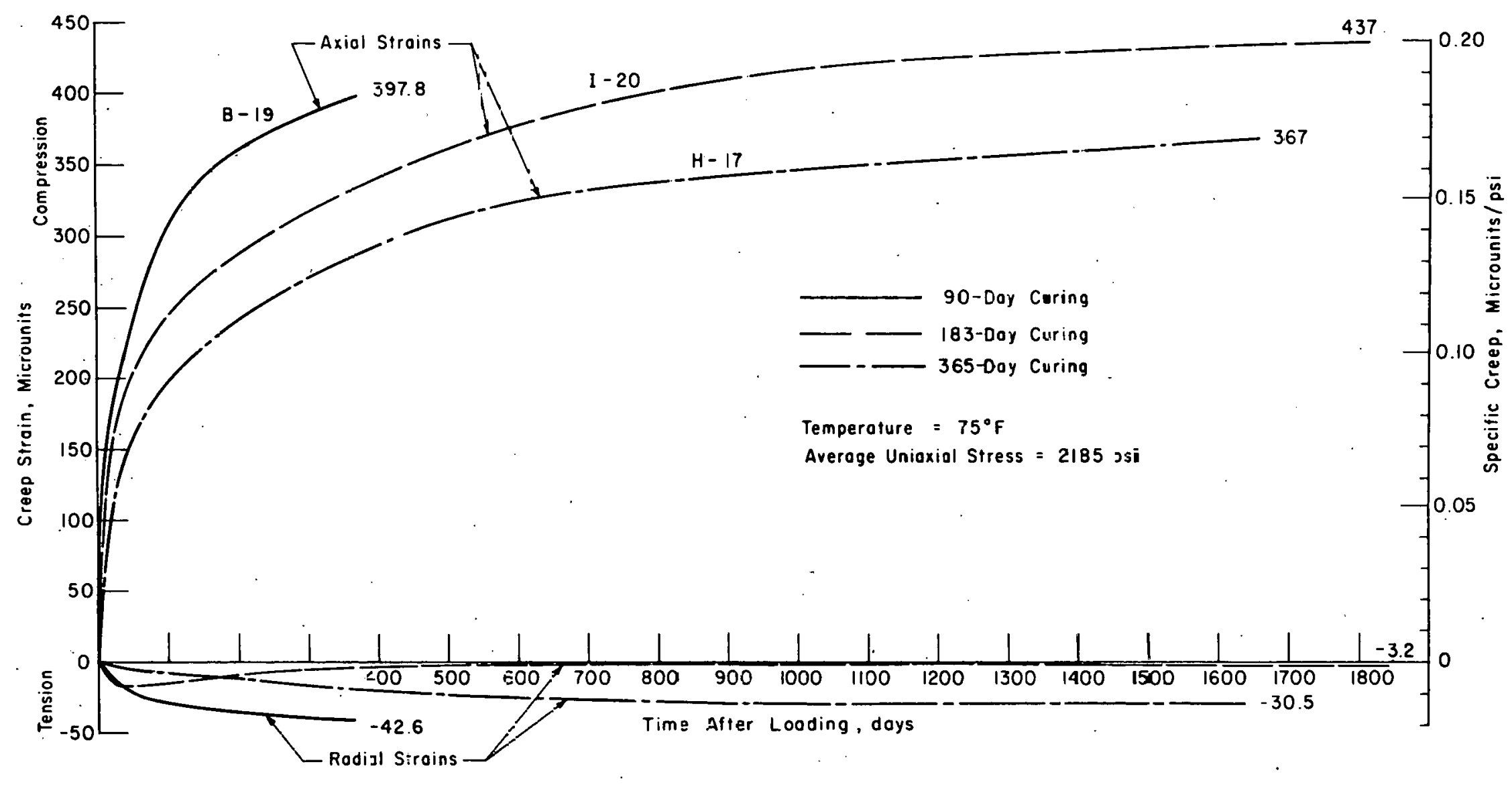

Fig 12. Axial and radial creef strain relationships for air-dried specimens with uniaxial stress of 2400 psi. 


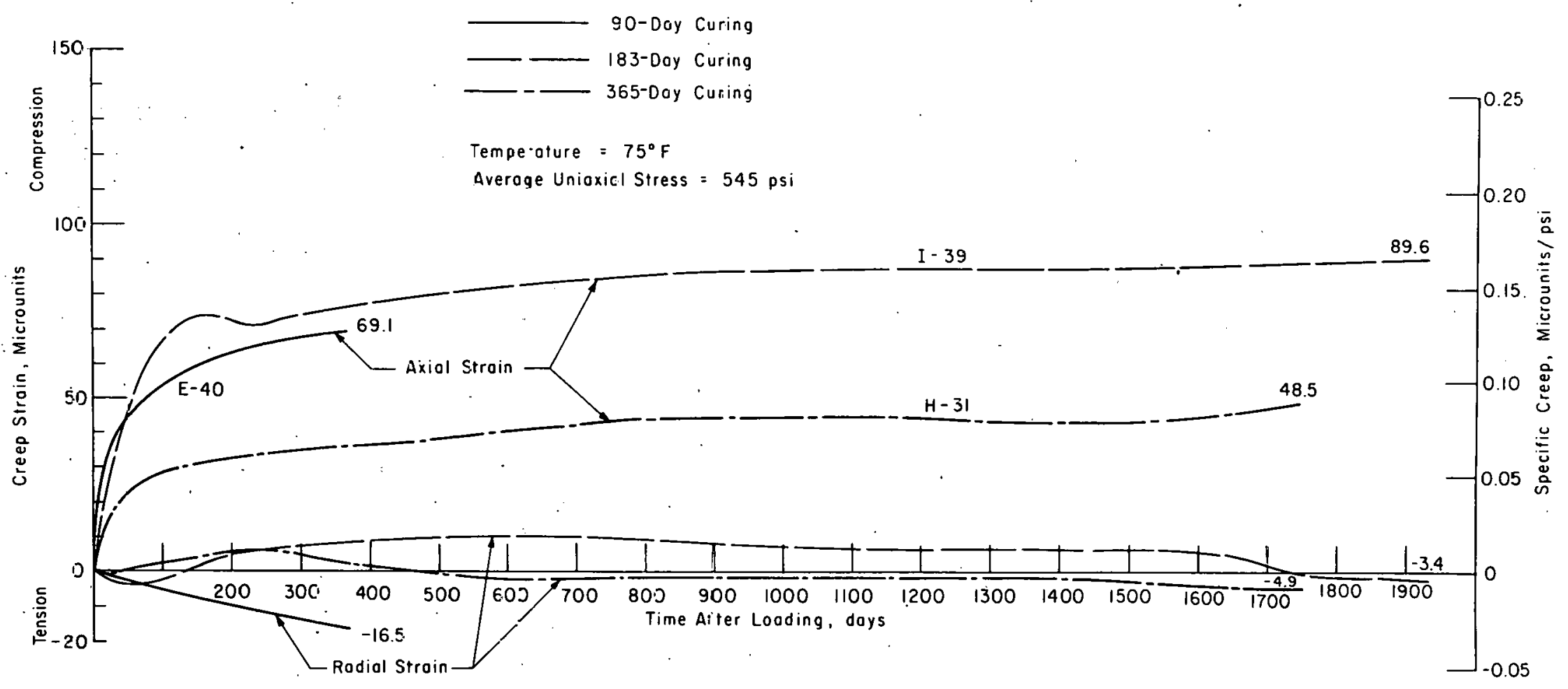

Fig 13. Axial and radial creep strain relationships for air-drièd specimens with uniaxial stress of 600 psi. 


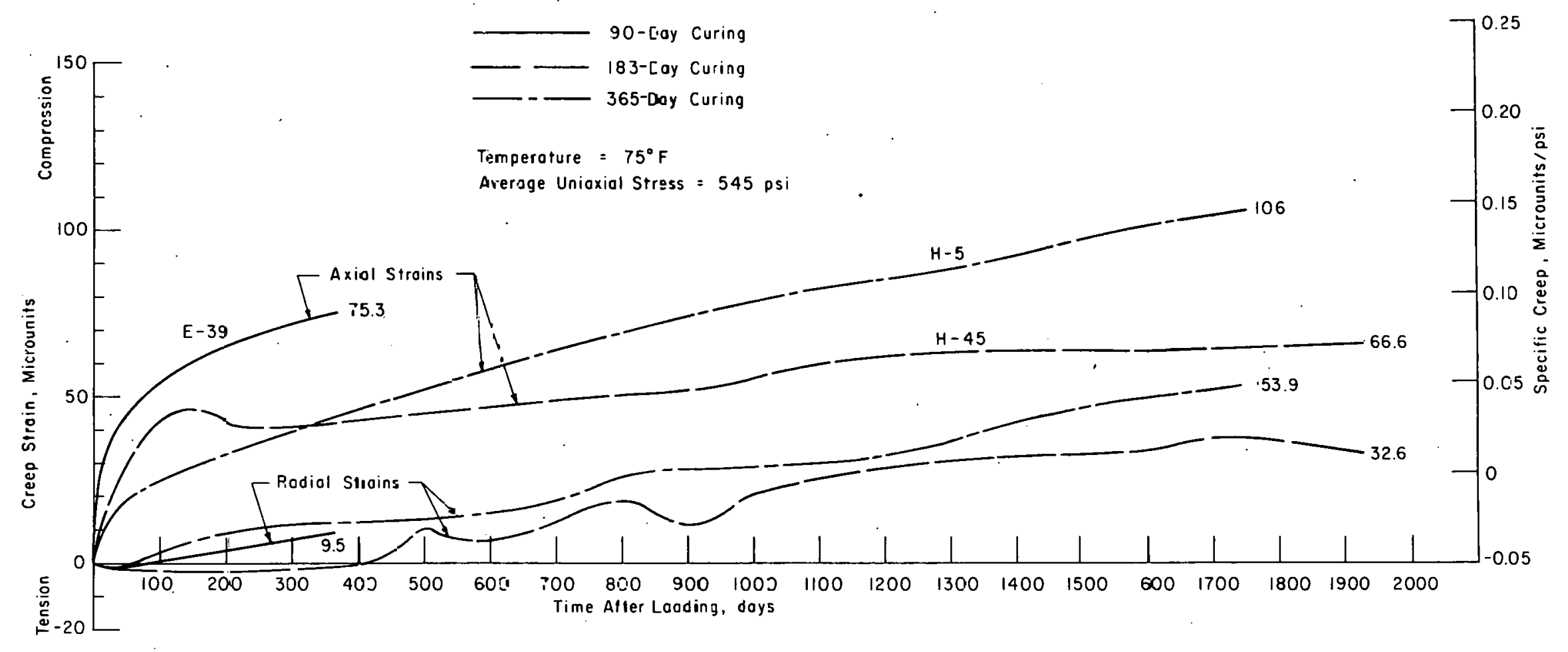

Fig 14. Axial and radial creep strain relationships for as-cast specimens wi ch uniaxia: stress of 600 psi. 


\section{Preliminary Analysis of 90-Day Specimens}

Subsequent to the completion of the loading period for the specimens cured for 90 days, the resulting creep strains were analyzed using analysis of variance and regression techniques (Ref 11). The five factors analyzed were temperature during loading, curing history, axial stress, radial stress, and time after loading. All five factors and a number of two-factor and threefactor interactions were found to produce effects which had practical significance. It generally was found that compressive and tensile creep strains for specimens cured for 90 days were larger for

(1) a test temperature of $150^{\circ} \mathrm{F}$ than for $75^{\circ} \mathrm{F}$,

(2) air-dried concrete than for as-cast concrete (except in the case. of low tensile creep, where the reverse was true),

(3) increased time after loading, and

(4) higher stresses for uniaxial and biaxial states of stress.

The effects produced by these factors are illustrated in Figs 11 through 27 for a variety of conditions involving 21 selected specimens.

Temperature During Loading. The general effects of temperature on axial and radial creep strains for a variety of stress conditions are shown in Figs 15 and 16. In all cases compressive and tensile creep strains were increased by increasing the temperature from 75 to $150^{\circ} \mathrm{F}$; however, the increase associated with increased temperature was greater for the high stress conditions.

Curing History. The general effects of curing history on axial and radial. creep strains for a variety of stress conditions are shown in Figs 17 and 18 . The air-dried specimens exhibited more compressive creep strain than the ascast specimens, but for conditions which produced relatively low tensile creep strains the air-dried specimens exhibited less tensile creep strain than the as-cast specimens. The increase in strain associated with air-drying was larger for the higher stress conditions.

Radial Stress. Figures 19 through 22 show the general effects of radial stress on axial and radial creep strains for a variety of axial stresses. For high axial stresses, axial creep strain was reduced and radial creep strain changed from tension to compression. For low axial stresses increasing radial stress changed the axial creep strain from compression to tension and changed 


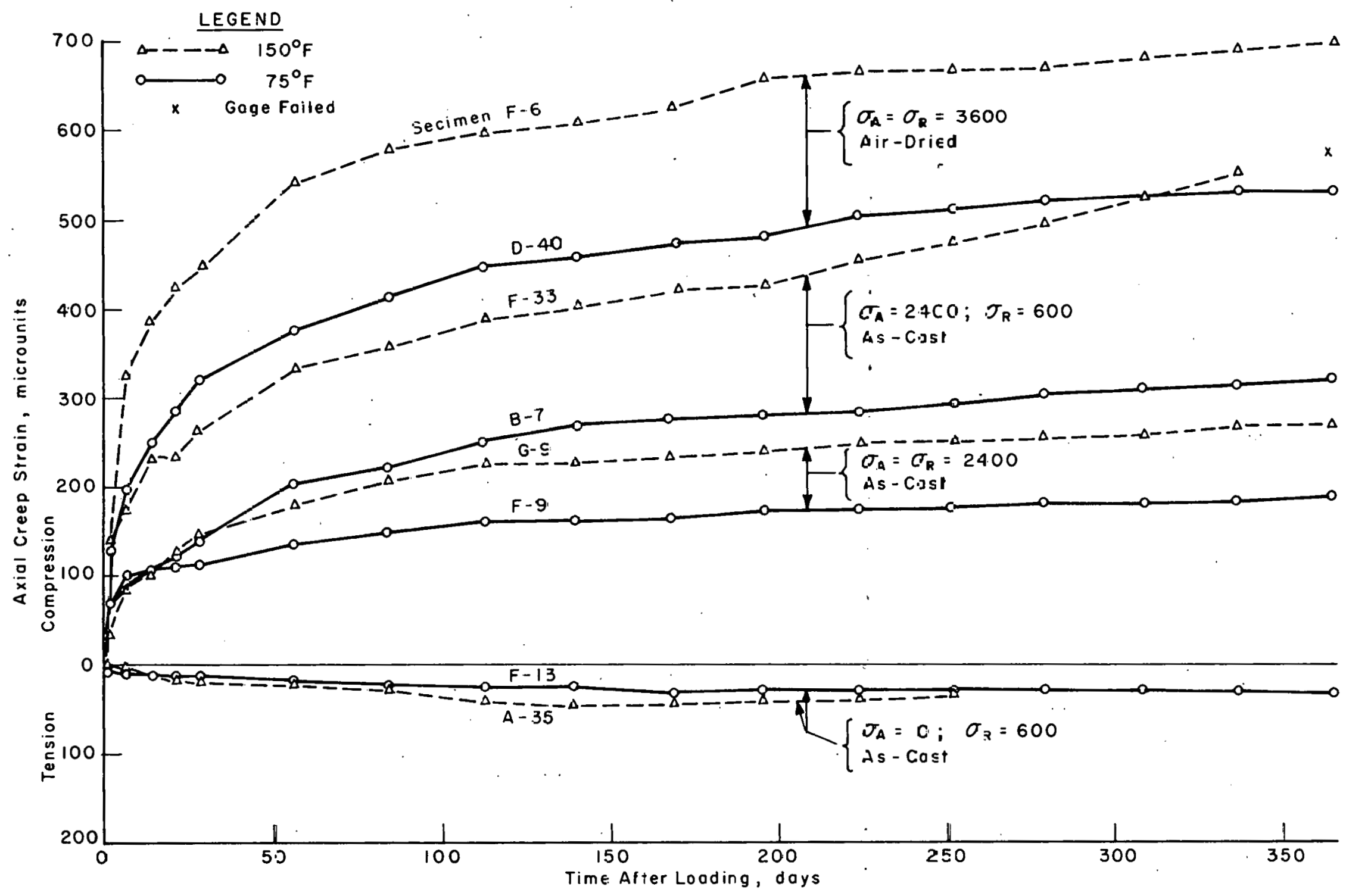

Fig 15. Effect of temperature on axial creep strain for a varizty of stress conditions. 


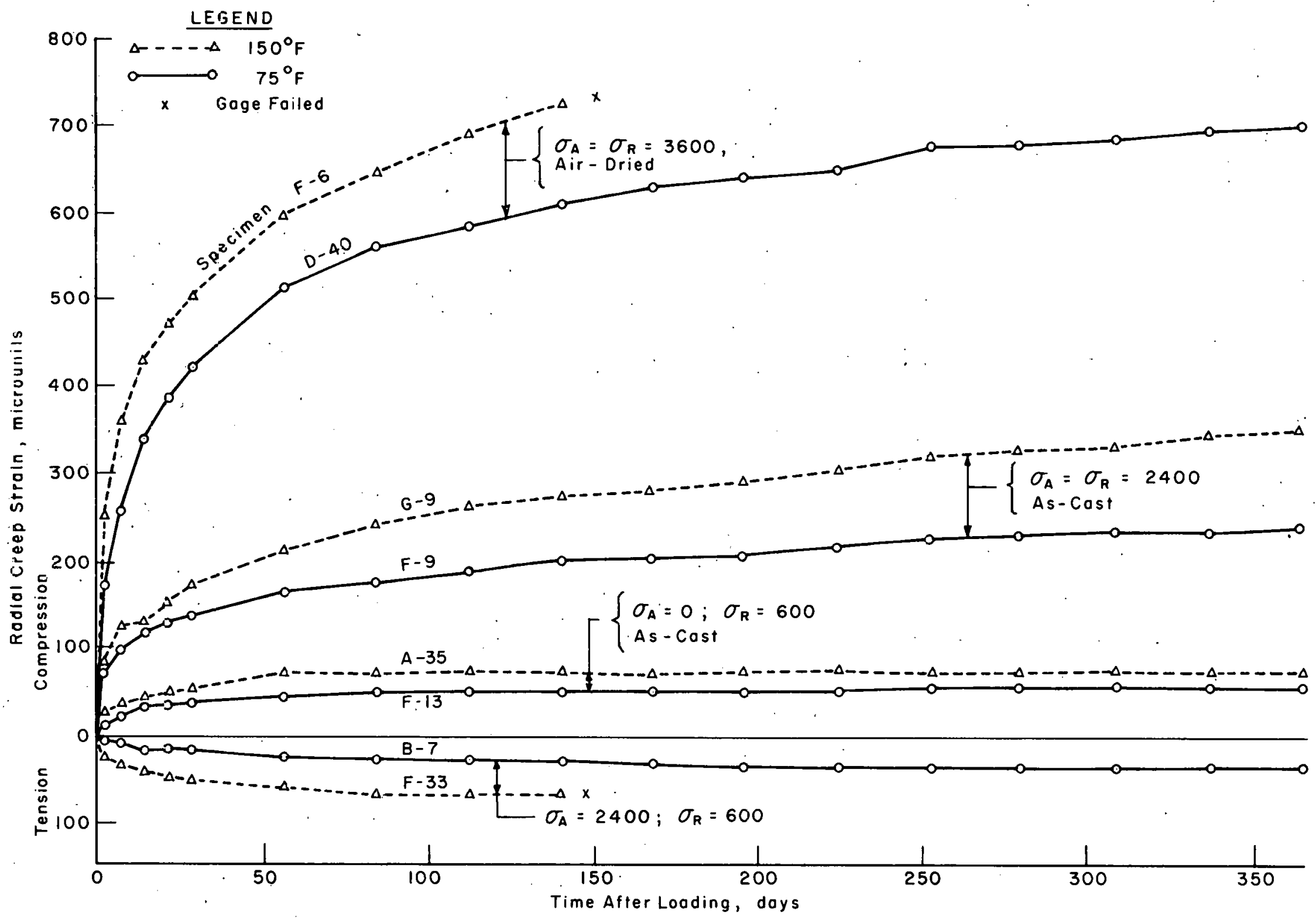

Fig 16. Effect of temperature on radial creep strain for a variety of stress conditions. 


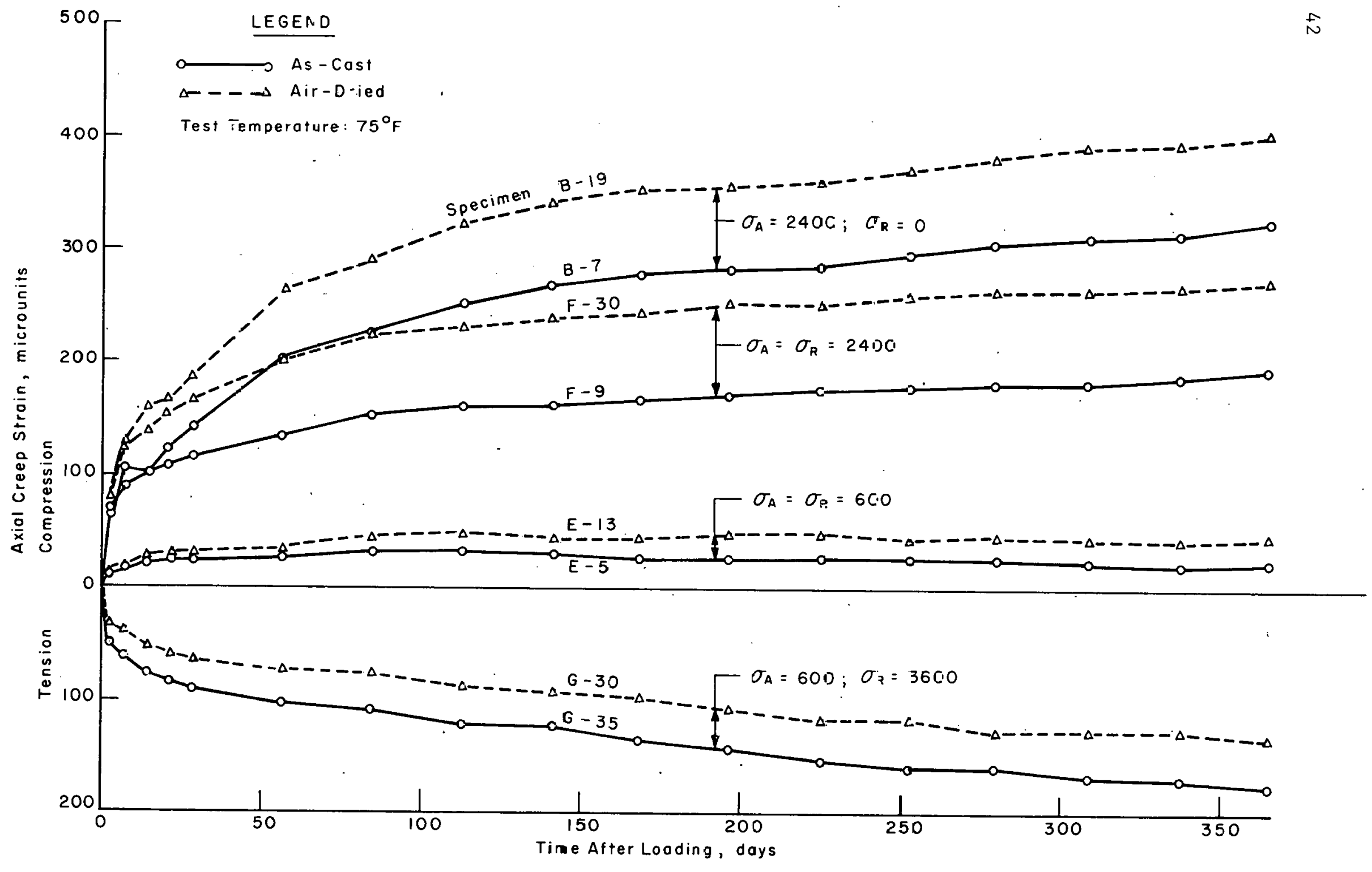

Fig 17. Effect of suring zistory on axial creef strain for a variety $o \equiv$ stress conditions. 


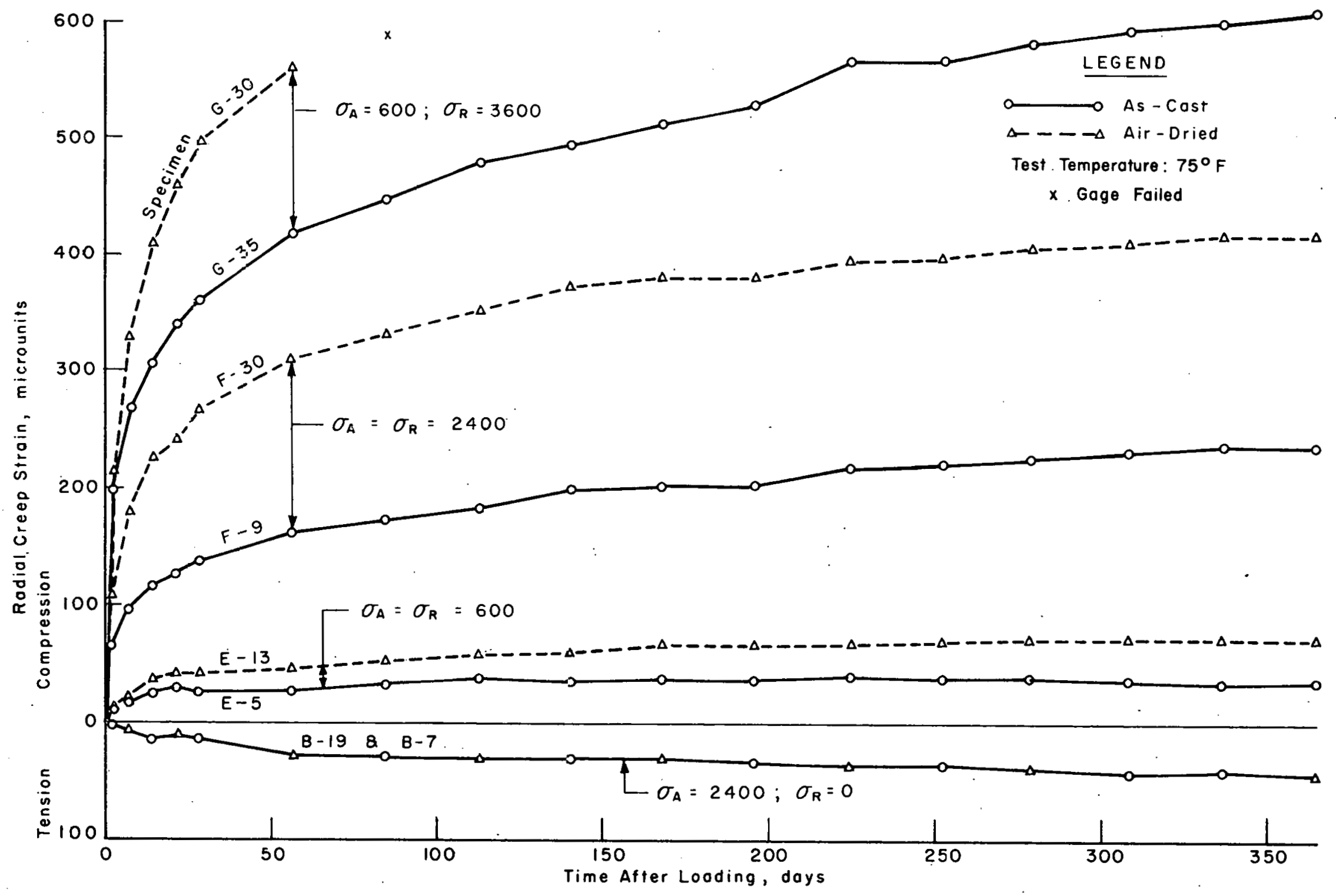

Fig 18. Effect of curing history on radial creep strain 


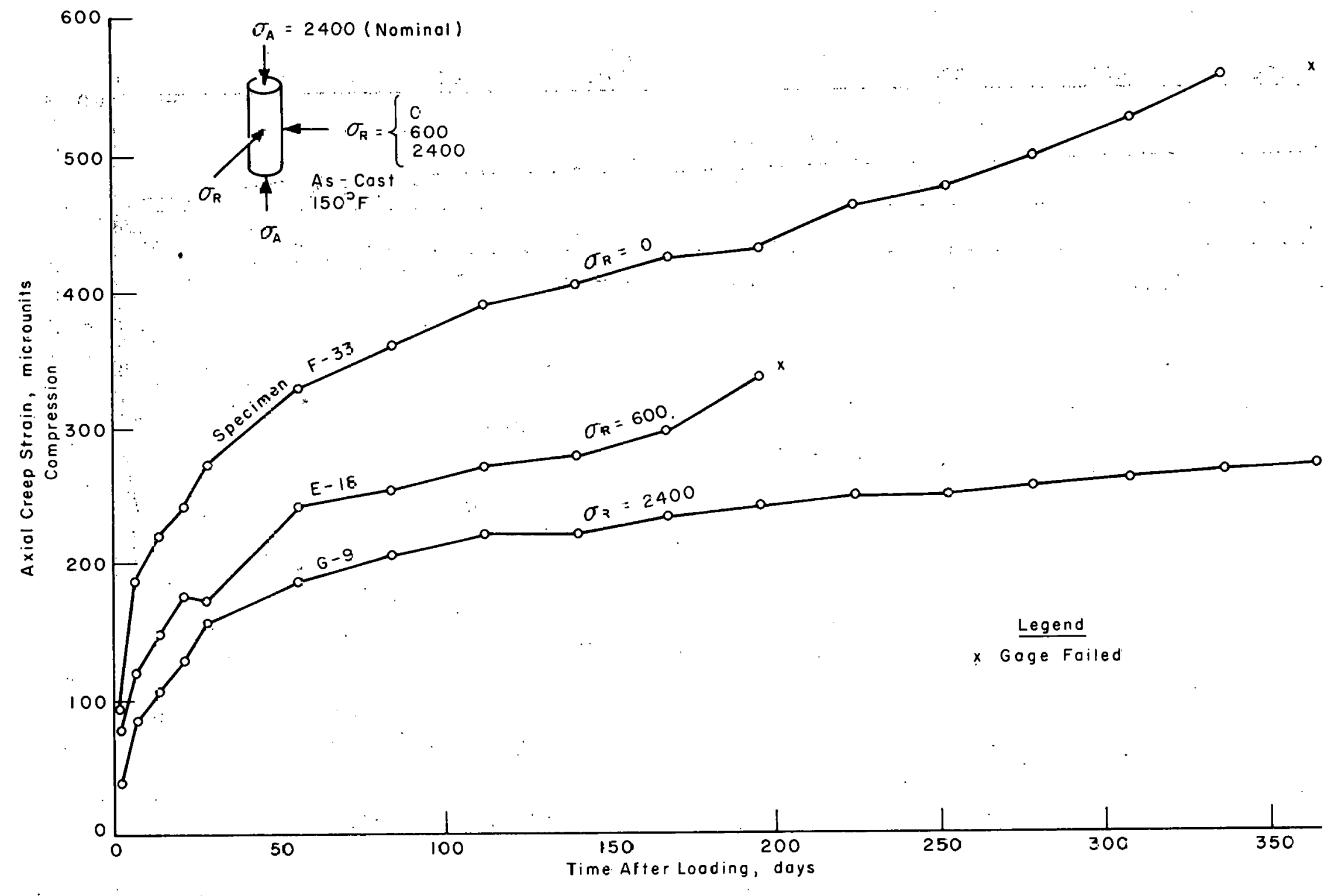

Fig 19. Effect o strain for a high axial stress. 


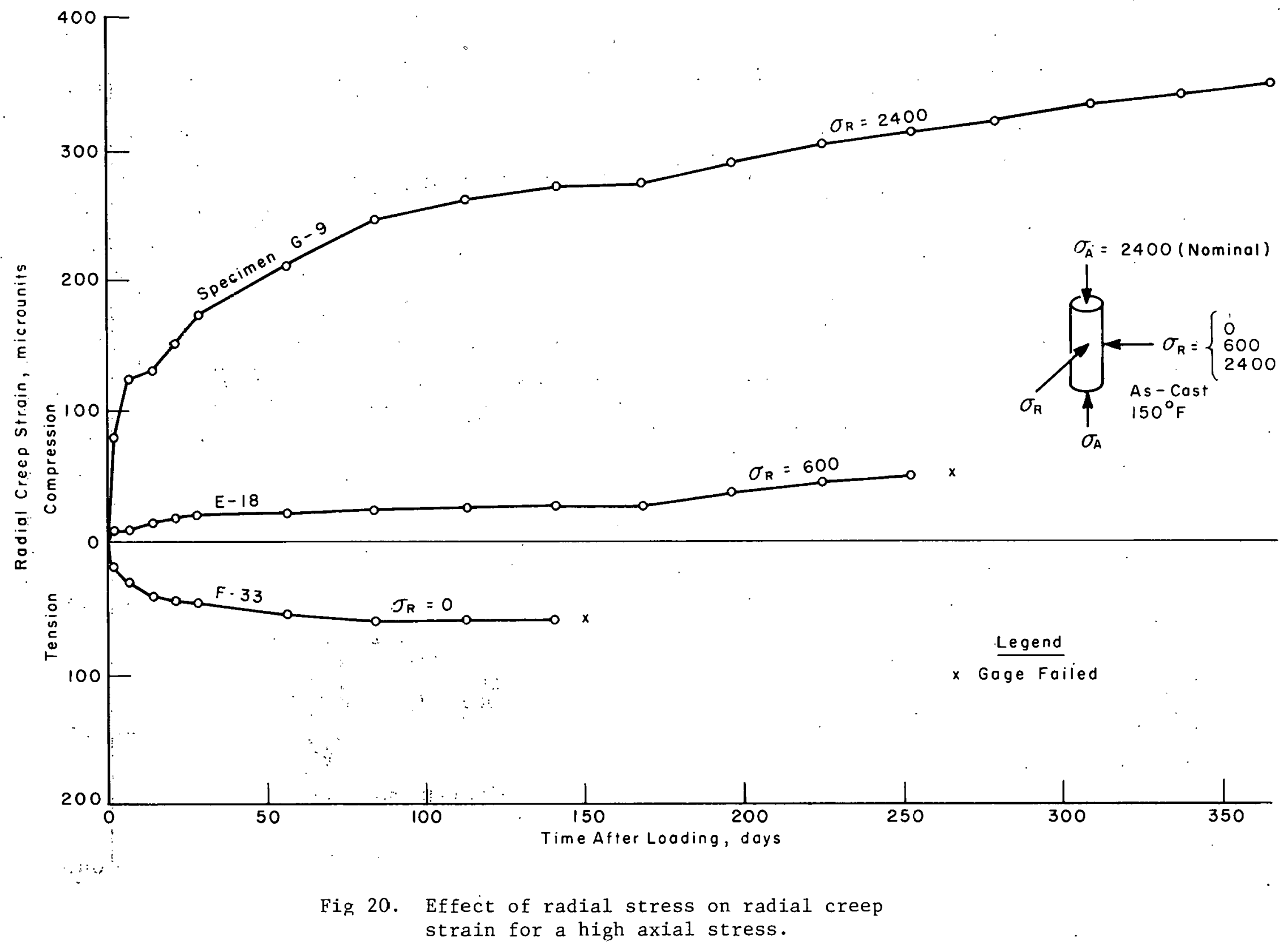




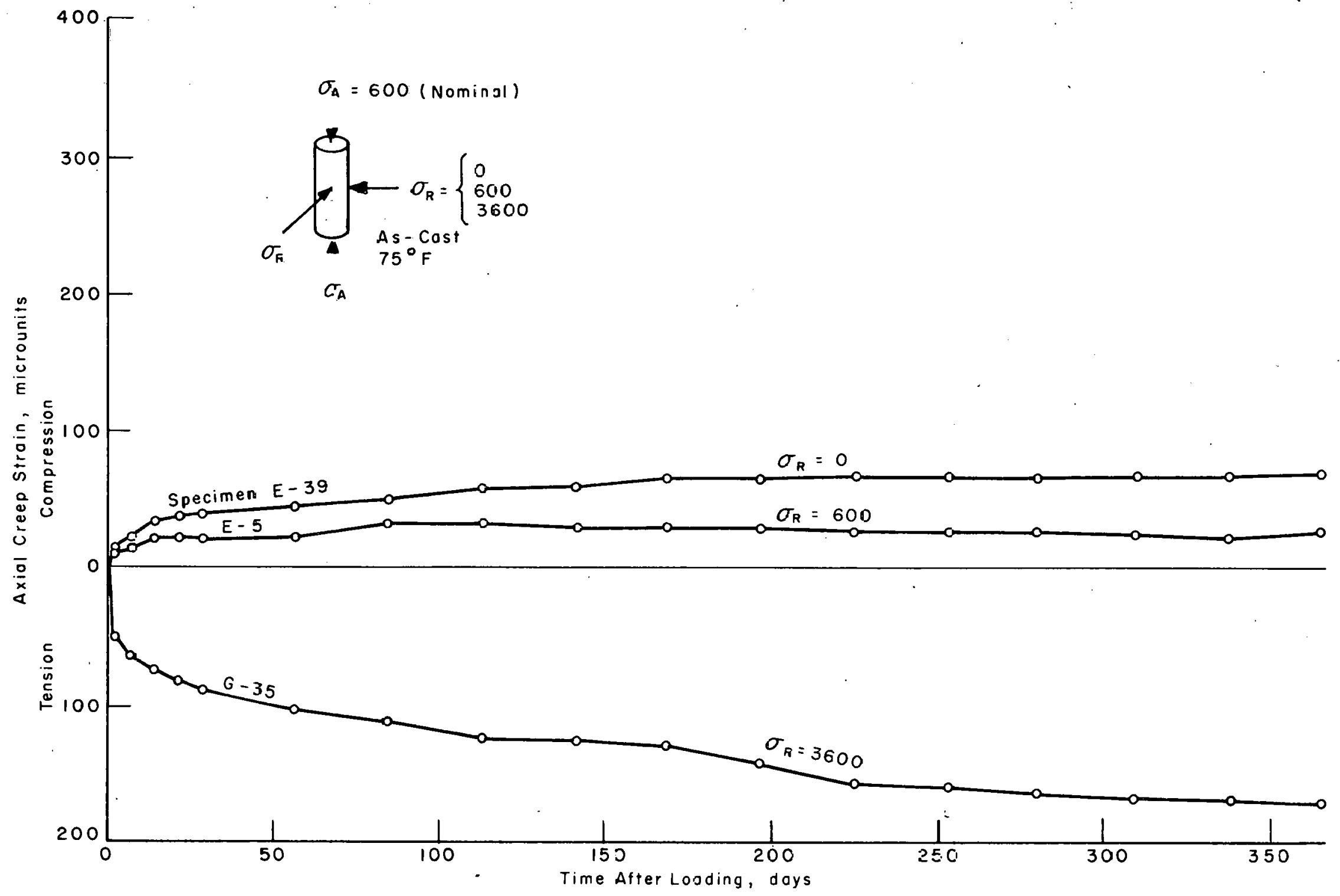

Fig 21. Effect of radial stress on axial creep strain for a low axial stress. 


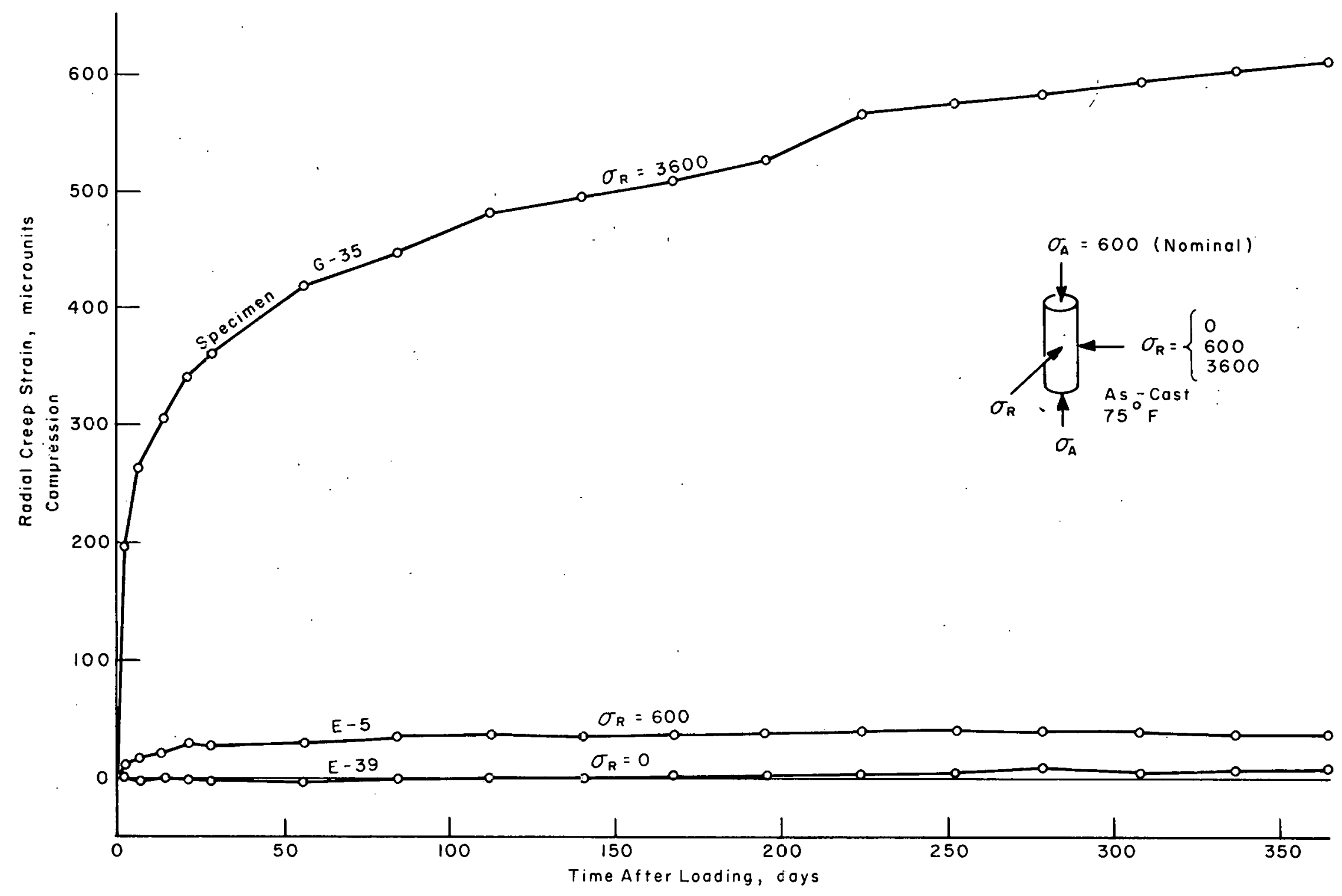

Fig 22. Effect of radial stress on radial creep 


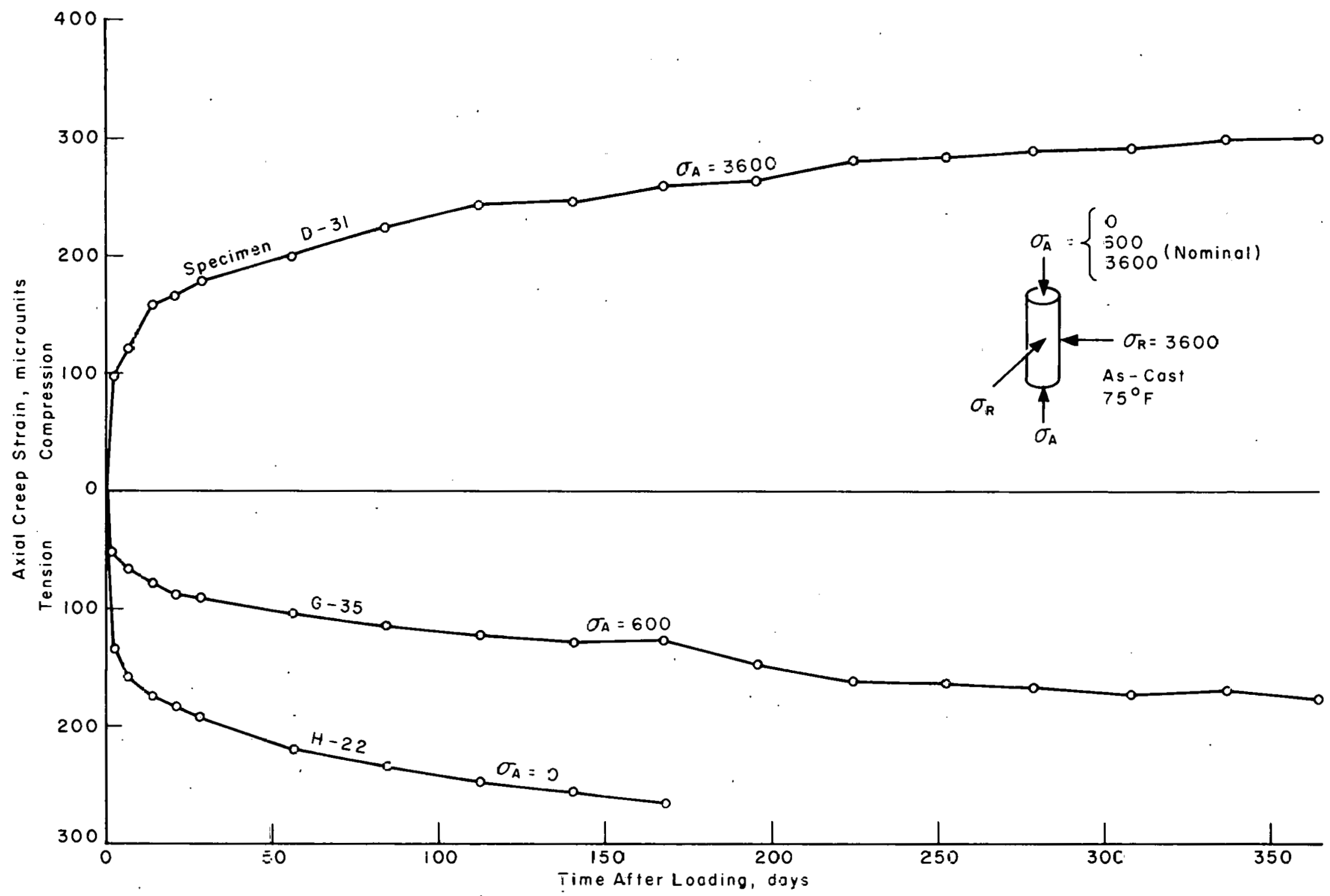

Fig 23. Effect of axial stress on axial creep strain fcr a high radial stress. 


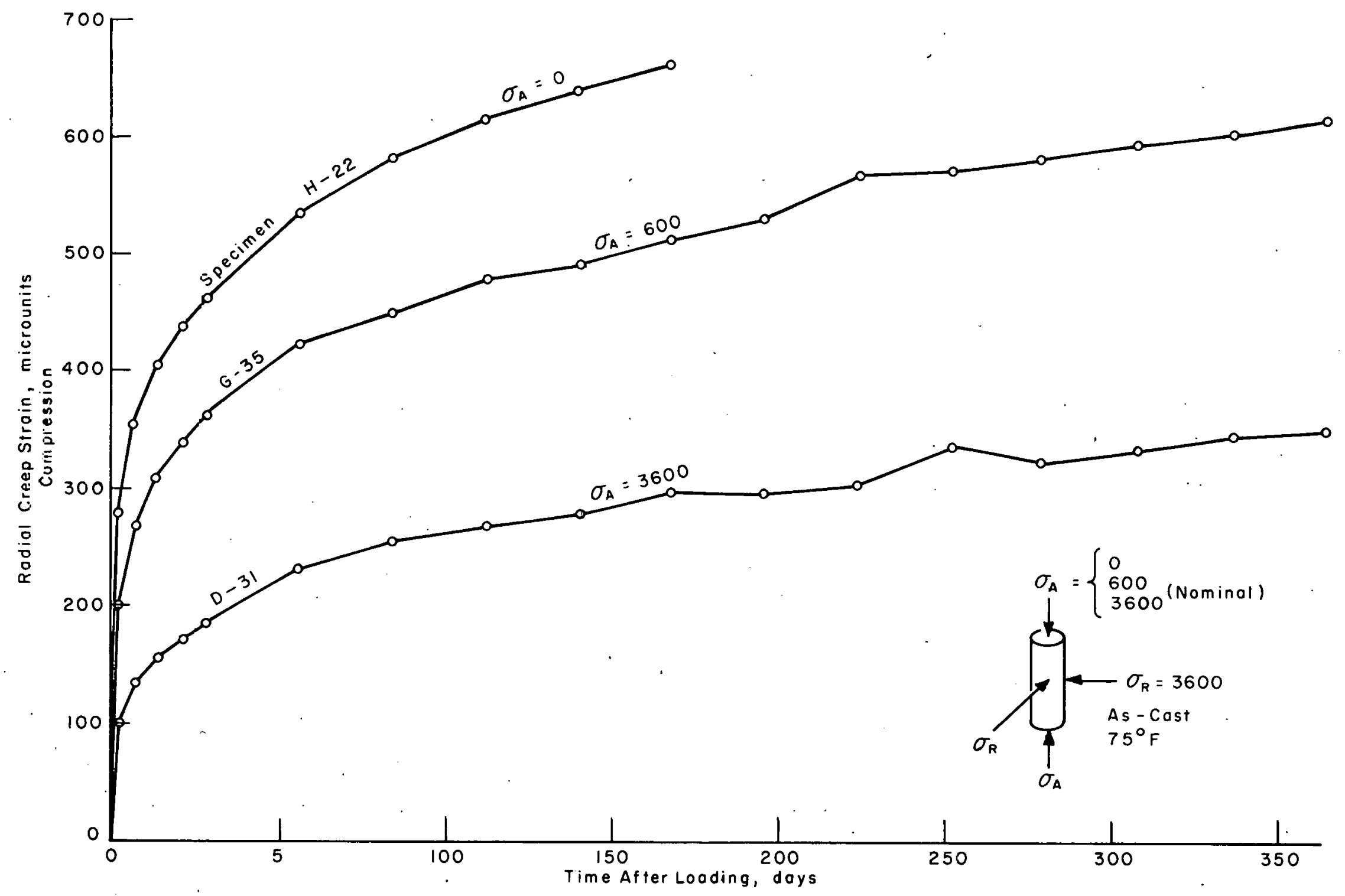

Fig 24. Effect of axial stress on radial creep strain for a high radial stress. 


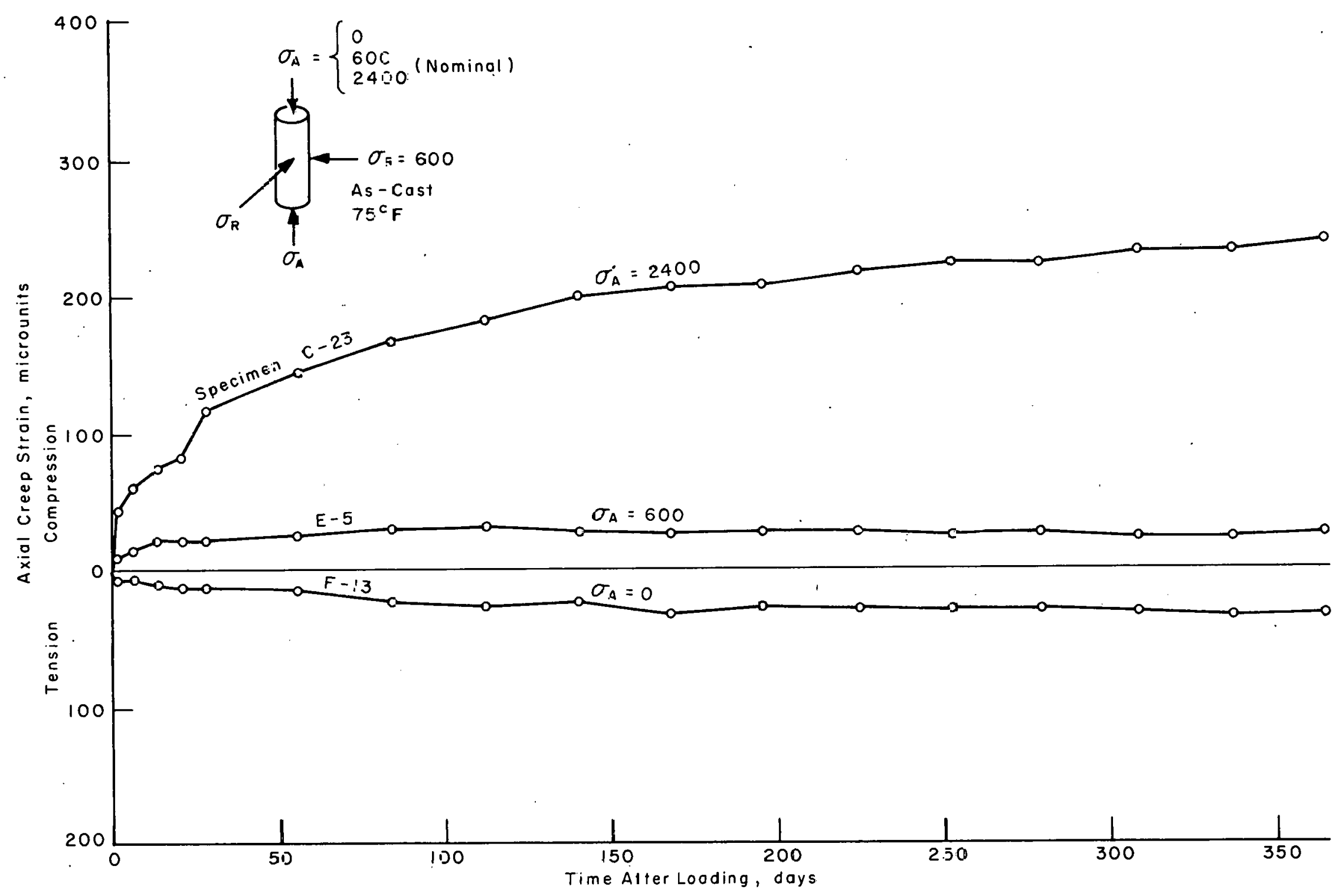

Fig 25. Effect of axial stress on axial creep strain for a low radial stress. 


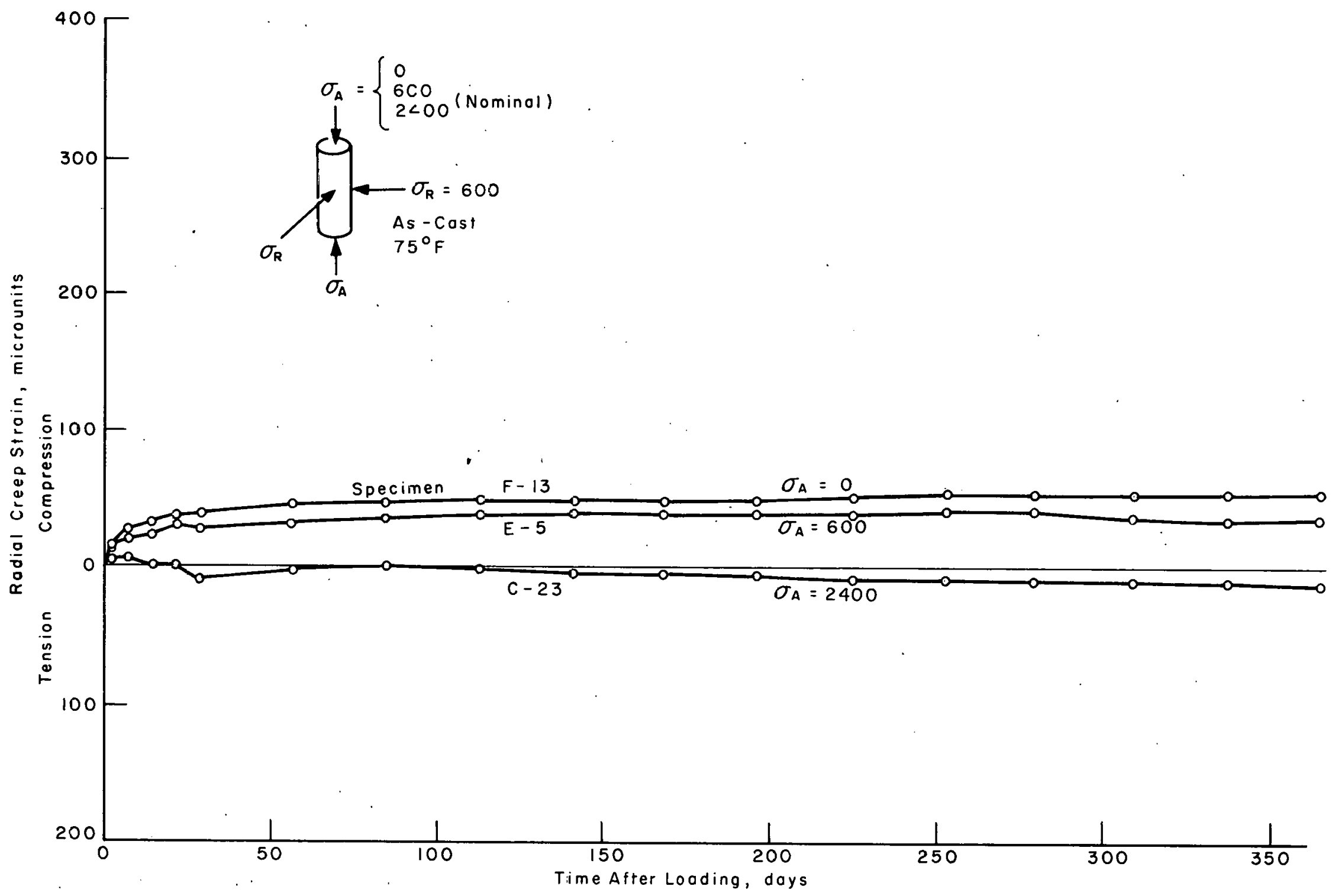

Fig 26. Effect of axial stress on radial creep strain uncer a low radial stress. 


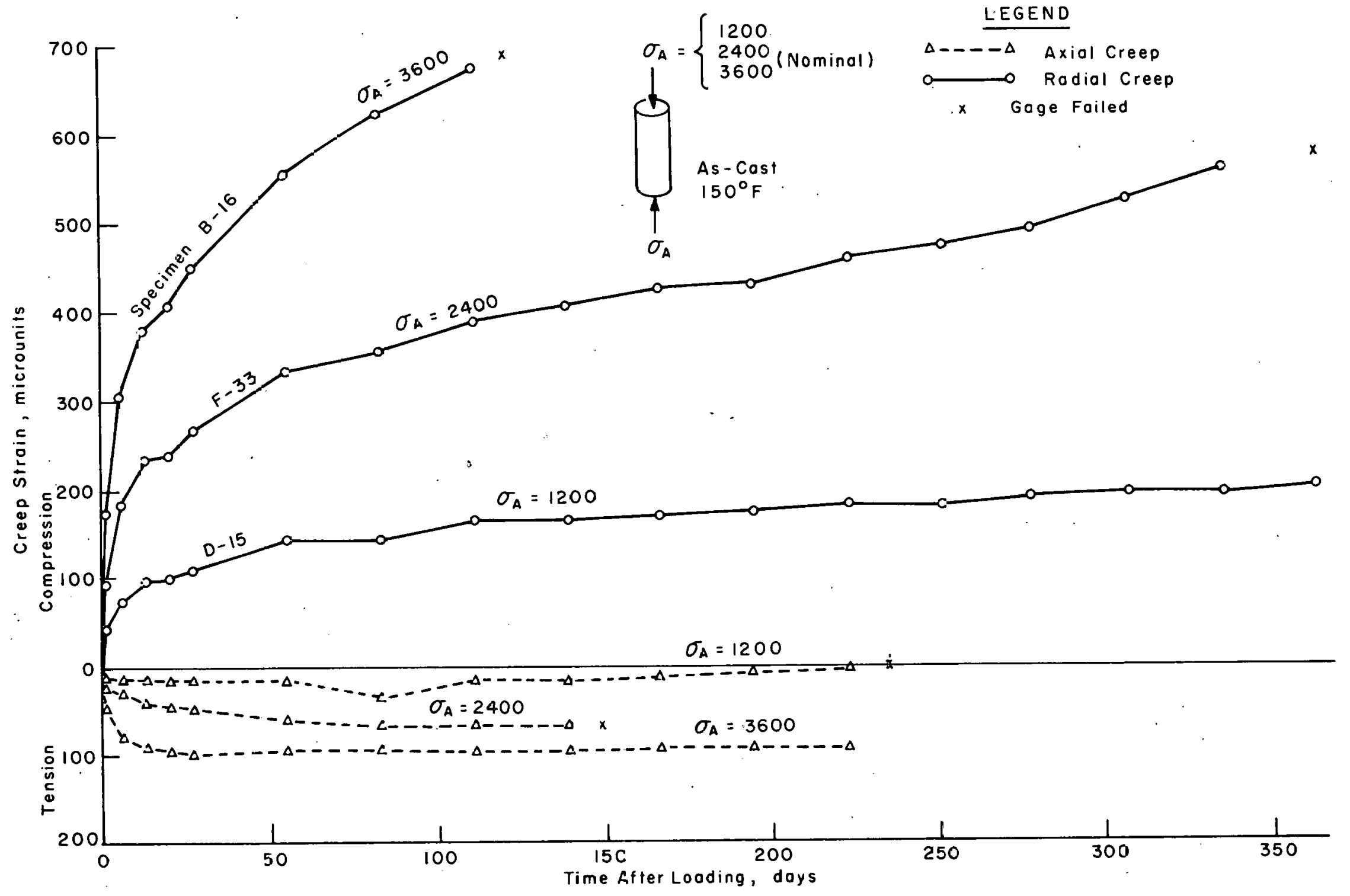

Fig 27. Effect of uniaxial stress on axial anc̈ radial creep strains. 
radial creep strain from tension to compression. Thus, a definite creep Poisson's effect was evident.

of considerable importance to the designer is the observed nonlinear relationship between stress and creep strain, particularly for multiaxial states of stress.

Axial Stress. The general effects of axial stress on the axial and radial creep strains for a variety of radial stresses are shown in Figs 23 through 26. The observations associated with axial stress are similar in nature to those indicated for radial stress. There was not as much nonlinearity associated with the uniaxial states of stress as with the triaxial states of stress.

Time After Loading. Typical time versus creep strain relationships, shown in Figs 15 through 27, illustrate the effects of time after loading for each of the main variables and a variety of loading conditions. Compressive and tensile creep strains increased with time after loading but at a decreasing rate. In addition, creep strains and creep rate were larger for those specimens exhibiting a large initial elastic strain.

Time-creep strain curves illustrating the influence of temperature during loading are shown in Figs 15 and 16 and the influence of curing history is shown in Figs 17 and 18. These figures indicate that the effects produced by curing history and temperature generally did not change with time. Thus, there were not significant interactions between time and temperature during loading nor between time and ruring history.

Time-creep strain relationships demonstrating the effect of radial stress for both a high and a low axial stress are shown in Figs 19 through 22 . The effect of axial stress for a high and a low radial stress are shown in Figs 23 through 26. As seen in these figures, an increase of either the axial or radial stress reduced the creep strain in the direction perpendicular to the direction of the increased stress. Thus, a definite creep Poisson effect was evident. It can also be seen that considerable creep strain occurred under hydrostatic states of stress and was still continuing after one year under load. Similar observations had been previously reported, as discussed in Ref 11 .

For comparison, the time-creep strain relationships for untaxial stresses are shown in Fig 27. The comparison indicated that the nonlinearity between 
stress and creep strain was greater for triaxial states of stress than for uniaxial states of stress.

Interaction Effects. The effects produced by the five factors were consistent with previous findings. These main effects provide an indication of the trends and the relative importance of each factor. The actual effect for any given set of conditions is dependent on the other factors as discussed above and as evidenced by the number of two and three-factor interactions. The significant interactions are discussed in detail in Ref 11.

From the allalyses of the creep behavior of the specimens cured for 90 days, it was found that the applied stress, particularly radial stress, was by far the most impul lanl factor affècting rreep behavior in thio study. Stress was not only significant in i.tself, but it also produced highly significant interactions with each of the other factors investigated. Since creep strain is usually considered to be proportional to stress at the lower stress levels and is nonlinear at higher stresses, the effect of other factors would be expected to increase as stress increased. Radial stress was generally more important than axial stress since it involved two principal stresses, rather than one. In addition, larger creep strains generally occurred in specimens which exhibited large initial elastic strains.

'lhe effects of the major interactions indicated that an increase of stress generally increased the creep strains, with the increase being larger for specimens at $150^{\circ} \mathrm{F}$ and for air-dried specimens. In addition, the increase was larger after longer periods under load. Increasing the confining pressure, however, tended to reduce the overall creep strains.

Long-Term Rehavier

The creep strain-time relatinnships for the oight cpccimeno cured fui 183 or 365 days and then athjected tu 600 or 2400 pai for approximalely 5.25 or 4.75 years are shown in Figs 11 through 14. The axial creep strain-time relationships for specimens subjected to 2400 psi are shown in Fig 28 . As is evident from these figures, the specimens were sontinuing to creep after 4.75 or 5.25 years under load.

Effect of Loading Age. A comparison of the creep strain-time relationships for specimens loaded with a nominal uniaxial stress of 2400 psi (Figs 11 and 12) indicated a definite effect of curing time prior to loading. Specimens 


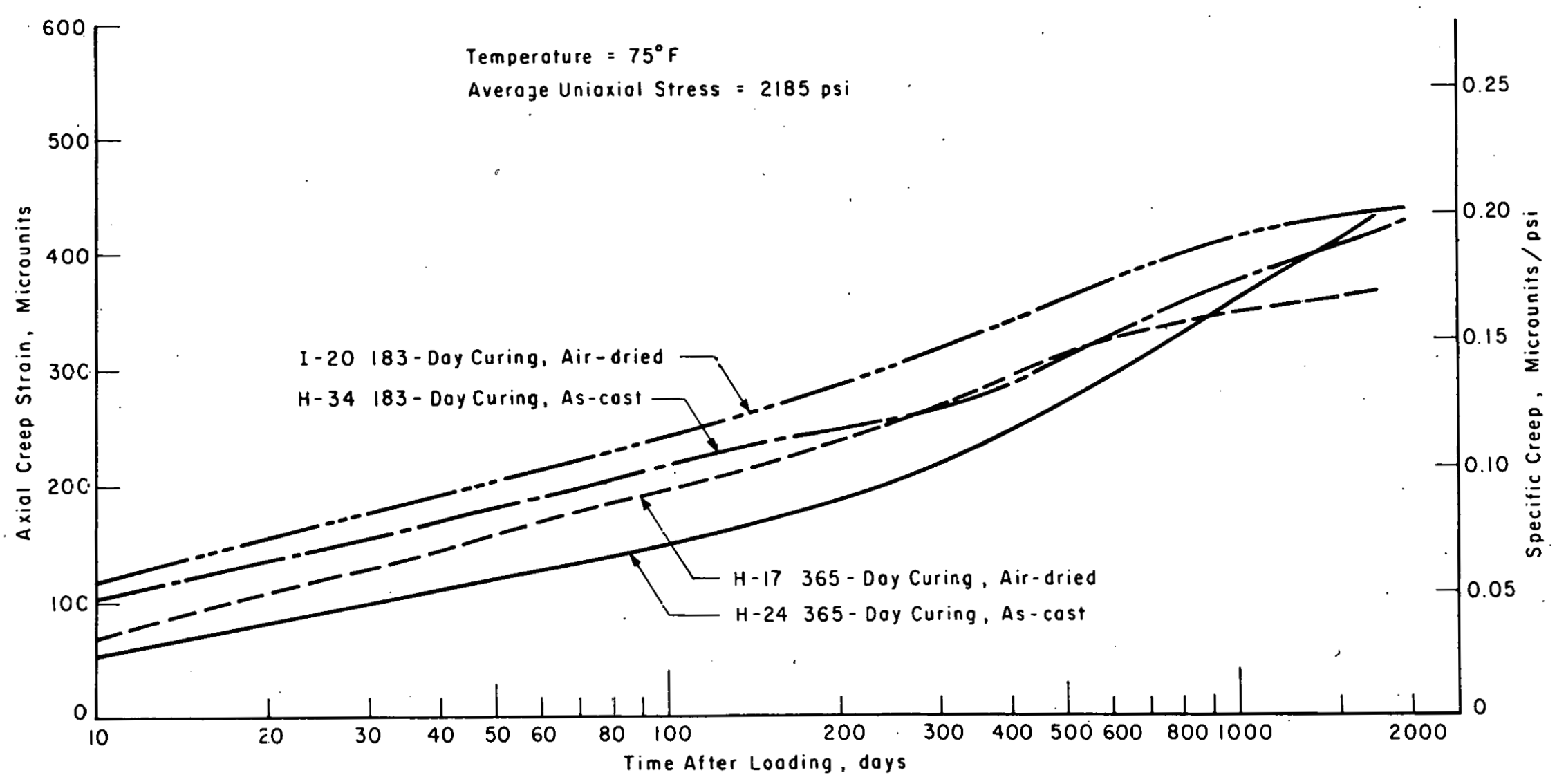

Fig 28. Relationship between axial creep strain and logarithm of time for specimens with uniaxial stress of 2400 psi. 
loaded after a longer curing period exhibited smaller axial and radial creep strains. In one case, however, this effect diminished with time. In fact, the creep strains for the 365-day specimen exceeded the creep strains for the 183-day specimen. A similar effect is also evident for the specimens loaded at 600 psi although it is not as pronounced, possibly due to the magnitude of the strains and the error introduced by the shrinkage relationships .

A summary of the ratio of the creep strains in the 183-day and 365-iay specimens to the creep strains in the 90-day specimens is contained in Table 11. During the first year under load, the creep strains in the specimens cured for 183 days or 365 days were approximately. 85 and 68 percent, respectively, of the creep strains in the specimens cured for 90 days.

Effect of Curing History. A comparison of the axial creep strains during the first 2.5 years under a load of 2400 psi (Table 12) indicates that the air-dried specimens exhibited larger axial creep strain than the as-cast specimens regardless of the age at loading. In addition, it was concluded in the preliminary evaluation (Ref 11 ) that the air-dried specimens exhibited larger creep strains throughout the one-year loaded period and that the relative magnitudes did not change with time. The ratios of the as-cast strains to the air-dried strains were fairly consistent, with the average. values for the 90,183 , and 365-day specimens being $0.80,0.86$, and 0.81 , respectively, and the overall average 0.82 . Thus, it was concluded that the creep strains in as-cast specimens at any given time were approximately 82 percent of the creep strains in air-dried specimens subjected to the same. stress level.

During the next 2.5 years, however, the ratios of the as-cast creep strains to the air-dried creep strains increased, indicating that the magnitudes of the as-cast and air-dried creep strains were approaching the same value. This may indicate that the air-dried specimens initially deformed at a much higher rate because moisture was free to move quickly and easily into the partially dry capillary voids and, therefore, the maximum creep strain was approached more quickly. With time, however, the moisture in the more saturated as-cast specimens was able to migrate, allowing creep to continue. The ultimate creep strain may be approximately the same for both as-cast and air-dried specimens, or,the ultimate creep strain may actually 
TABLE 11. RATIO OF AXIAL CREEP STRAINS FOR 183 AND 365-DAY SPECIMENS TO CREEP STRAINS FOR 90-DAY SPECIMENS

\begin{tabular}{|c|c|c|c|c|c|c|}
\hline \multirow{3}{*}{$\begin{array}{l}\text { Days after } \\
\text { Loading }\end{array}$} & \multicolumn{6}{|c|}{ Curing Time and History } \\
\hline & \multicolumn{3}{|c|}{183 Days } & \multicolumn{3}{|c|}{365 Days } \\
\hline & Air-Dried & As-Cast & Average & Air-Dried & As-Cast & Average \\
\hline 28 & 0.97 & 1.00 & 0.98 & 0.70 . & $0.6 \dot{6}$ & 0.68 \\
\hline 56 & 0.83 & 0.91 & 0.87 & 0.64 & 0.62 & 0.63 \\
\hline 84 & 0.81 & 0.90 & 0.85 & 0.64 & 0.61 & 0.63 \\
\hline 168 & 0.81 & 0.86 & 0.84 & 0.67 & 0.65 & 0.66 \\
\hline 252 & 0.83 & 0.88 & 0.86 & 0.71 & 0.71 & 0.71 \\
\hline 364 & 0.83 & 0.88 & 0.85 & 0.73 & 0.75 & 0.74 \\
\hline Average & $\begin{array}{l}0.85 \\
(0.82) *\end{array}$ & $\begin{array}{l}.0 .91 \\
(0.89) *\end{array}$ & $\begin{array}{l}0.88 \\
(0.85) *\end{array}$ & 0.68 & 0.67 & 0.68 \\
\hline
\end{tabular}

* Excluding value 28 days after loading. 
TABLE 12. EFFECT OF CURING HISTORY ON LONG-TERM AX_AL

\begin{tabular}{|c|c|c|c|c|c|c|c|c|c|}
\hline \multirow[b]{2}{*}{$\begin{array}{l}\text { Days After } \\
\text { Loading }\end{array}$} & \multicolumn{9}{|c|}{ Ctring Time and History } \\
\hline & $\begin{array}{c}(B-7) \\
A s-C \equiv s t\end{array}$ & $\begin{array}{c}90 \text { Days } \\
(B-1 \Xi) \\
\text { Air-Dried }\end{array}$ & Ratio** & $\begin{array}{l}(\mathrm{H}-34) \\
\text { As-Cast }\end{array}$ & $\begin{array}{c}183 \text { Days } \\
(\mathrm{I}-20) \\
\text { Air-Dried }\end{array}$ & Ratio** & $\begin{array}{l}(\mathrm{H}-24) \\
\text { es-Cast }\end{array}$ & $\begin{array}{c}365 \text { Days } \\
(\mathrm{H}-17) \\
\text { Air-Dried }\end{array}$ & Ratio** \\
\hline 28 & $15 \equiv$ & 185 & 0.84 & 155 & 180 & 0.86 & $\therefore 02$ & 130 & 0.78 \\
\hline 56 & 203 & 261 & 0.78 & 186. & 216 & 0.86 & -25 & 167 & 0.75 \\
\hline 84 & 233 & 295 & 0.79 & 209 & 239 & 0.87 & -43 & 190 & 0.75 \\
\hline 168 & 275 & 348 & 0.79 & 238 & 280 & 0.85 & $\vdots 79$ & 232 & 0.77 \\
\hline 252 & 290 & 368 & 0.79 & 255 & 306 & 0.83 & $\leq 06$ & 260 & 0.79 \\
\hline 365 (1 yr) & 319 & 398 & 0.80 & 280 & 330 & 0.85 & $\therefore 39$ & 290 & 0.82 \\
\hline 547 (1.5 yrs) & -- & -- & -- & 321 & 371 & 0.86 & 290 & 329 & 0.88 \\
\hline 730 (2 yrs) & -- & -- & -- & 351 & 400 & 0.88 & $\equiv 15$ & 340 & 0.93 \\
\hline 924 (2.5 yrs) & -- & -- & -- & 364 & 413 & 0.88 & 351 & 343 & 1.02 \\
\hline 1096 (3 yrs) & -- & -- & -- & 382 & 421 & 0.91 & 374 & 350 & 1.07 \\
\hline 1279 (3.5 yrs) & -- & -- & -- & 394 & 426 & 0.92 & 392 & 356 & 1.10 \\
\hline 1461 (4 yrs) & -- & -- & -- & 403 & 430 & 0.94 & $40 ?$ & 362 & 1.12 \\
\hline $1643(4.5 y z s)$ & -- & -- & -- & 413 & 433 & 0.95 & $4 \geq 3$ & 367 & 1.15 \\
\hline 1748 (4.75 grs) & -- & -- & -- & 418 & 435 & 0.96 & 433 & 368 & 1.18 \\
\hline $1826(\dot{5} \mathrm{yrs})$ & -- & -- & -- & 423 & 437 & 0.97 & -- & -- & -- \\
\hline 1930 (5.25 grs) & -- & -- & - & 428 & 438 & 0.98 & -- & -- & -- \\
\hline $\begin{array}{c}\text { Average } \\
\text { (from } \operatorname{Ref} \measuredangle)\end{array}$ & -- & -- & 0.80 非 & -- & - & 0.86 非非 & -- & -- & 0.81 非非 \\
\hline
\end{tabular}

*Uniaxial stress $=2 \dot{4} 00 \mathrm{psi}$

Temperature $\quad=75^{\circ} \mathrm{F}$

$* *$ Ratio of as-cast to air-dried strains
\#Average for first year

非Average for first 2.5 years

非非A verage for first 2 years 
be greater for the as-cast specimens because of the greater quantity of water involved. The observed behavior could also suggest that the as-cast specimens were also losing moisture over an extended period of time since loss of water would be expected to have a greater effect on these specimens.

\section{Creep Poisson's Ratio}

The results definitely indicate the existence of a creep Poisson's effect. Prior to this study, some investigators had reported no creep Poisson's effect, or that creep Poisson's ratio was approximately zero, while others reported that creep Poisson's ratio was approximately equal to the elastic Poisson's ratio (Ref 11). Possibly part of this discrepancy was due to the different test conditions and to the different methods used to determine the magnitude of creep Poisson's ratio.

In this study the following expression was used to calculate the creep Poisson's ratio for cylindrical specimens subjected to the various states of stress:

$$
\nu_{c}=\frac{\sigma_{a}\left(\varepsilon_{c}\right)_{r}-\sigma_{r_{r}}\left(\varepsilon_{c}\right)_{a}}{2 \sigma_{r}\left(\varepsilon_{c}\right)_{r}-\left(\varepsilon_{c}\right)_{a}\left(\sigma_{r}+\sigma_{a}\right)} .
$$

where

$$
\begin{aligned}
& \nu_{c}=\text { creep Poissun's ratio; } \\
& \sigma_{a}=\text { axial stress, psi } \\
& \sigma_{I}=\text { rad1al sLress, psi; } \\
& \left(\varepsilon_{c}\right)=\text { creep strain in axial direction; } \\
& \left(\varepsilon_{c}\right)_{r}=\text { creep strain in radial direction. }
\end{aligned}
$$

90-Day Specimens. Creep Poisson's ratios for all 90-day cured specimens at various times during the loading period are presented in Table 13. For the concrete cured for 90 days and subjected to load for one year it was concluded that

(1) A creep Poisson's effect occurred and creep Poisson's ratio values ranged from approximately 39 percent to 84 percent of the elastic Poisson's ratio. The actual magnitude depended primarily on curing history prior to loading, temperature, and state of stress. The 
TABLE 13. CREEP POISSON"S RATIO FOR 90-DAY CURED SPECIMENS* $75^{\circ} \mathrm{F}$, As-Cast

\begin{tabular}{|c|c|c|c|c|c|c|c|c|}
\hline Specimen & $\begin{array}{l}\text { 3tre } \\
\text { Axial }\end{array}$ & $\begin{array}{l}\text { psi } \\
\text { Radial }\end{array}$ & $\begin{array}{l}\text { at } \\
28\end{array}$ & $\begin{array}{c}\text { Creep } \\
\text { follow } \\
84\end{array}$ & $\begin{array}{l}\text { isso } \\
\text { day } \\
140\end{array}$ & $\begin{array}{l}\text { 's Rat } \\
\text { after } \\
224\end{array}$ & $\begin{array}{l}\text { Loadin } \\
364\end{array}$ & $\operatorname{Avg}$ \\
\hline$B-7$ & 2179 & 0 & .10 & .13 & .12 & .13 & .13 & \\
\hline$C-16 x$ & 1100 & 0 & .22 & .23 & .29 & .34 & .41 & \\
\hline$C-23 \cdots$ & $2139^{\circ}$ & 600 & .28 & .23 & .24 & .25 & .26 & \\
\hline$D-26$ & 3449 & $1200^{\circ}$ & .18 & .19 & .21 & .21 & .22 & \\
\hline $\mathrm{D}-3 i$ & 3472 & 3600 & -.36 & .31 & .31 & .2 .2 & .33 & 19 \\
\hline$E-5$ & $56 ?$ & 600 & .29 & .08 & .33 & .38 & .39 & \\
\hline $\mathrm{F}-9$ & 2147 & 2400 & .15 & .09 & .20 & .20 & .19 & \\
\hline$F-13$ & 0 & 600 & .15 & .21 & .21 & .23 & .24 & \\
\hline$G-35$ & 536 & 3600 & .18 & .18 & .18 & .18 & .19 & \\
\hline $\mathrm{H}-22$ & 0 & 3600 & .17 & .17 & .17 & & & \\
\hline \multicolumn{3}{|c|}{ Average. } & .18 & .18 & .19 & .20 & .21 & \\
\hline
\end{tabular}

$75^{\circ} \mathrm{F}$, Air-Dried

\begin{tabular}{|l|rr|rrrrr|l|}
\hline $\mathrm{B}-19$ & 2179 & 0 & .08 & .10 & .09 & .10 & .11 \\
$\mathrm{C}-11$ & 2139 & 600 & .17 &. .19 & .21 & .22 & .23 \\
$\mathrm{D}-40$ & .3472 & 3600 & .40 & .41 & .41 & .40 & .40 & \\
$\mathrm{D}-44$ & 3449 & 1200 & .11 & .11 & & & & \\
$\mathrm{E}-13$ & 562 & 600 & .37 & .35 & .38 & .37 & .41 & 0.14 \\
$\mathrm{E}-40$ & 527 & 0 & .10 & .10 & .13 & .16 & .24 \\
$\mathrm{~F}-30$ & 2147 & 2400 & .33 & .31 & .32 & .32 & .32 \\
$\mathrm{~F}-42$ & 0 & 600 & .10 & .14 & .13 & .14 & .17 \\
$\mathrm{G}-30$ & 536 & 3600 & .13 & & & & \\
$\mathrm{H}-14$ & 0 & 3600 & .14 & & & & \\
\hline \multicolumn{2}{l|}{ Average } & & & .12 & .13 & .14 & .16 & .19 \\
\hline
\end{tabular}

$150^{\circ} \mathrm{F}$, As-Cast

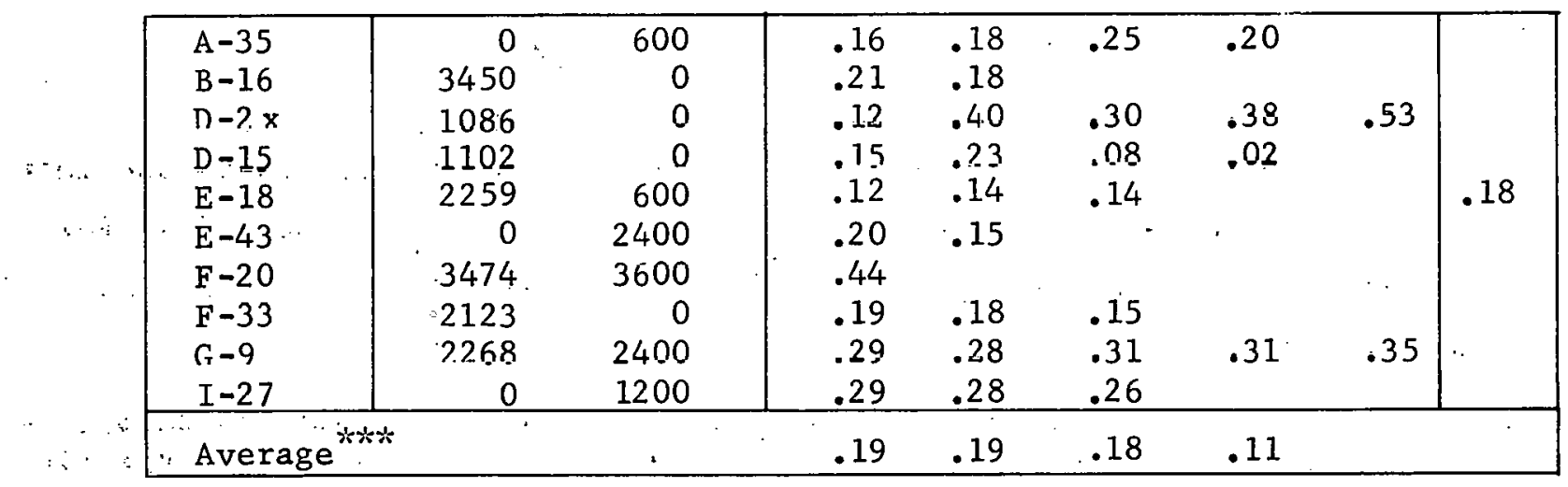

(Continued) 
TABLE 13. (CONTINUED).

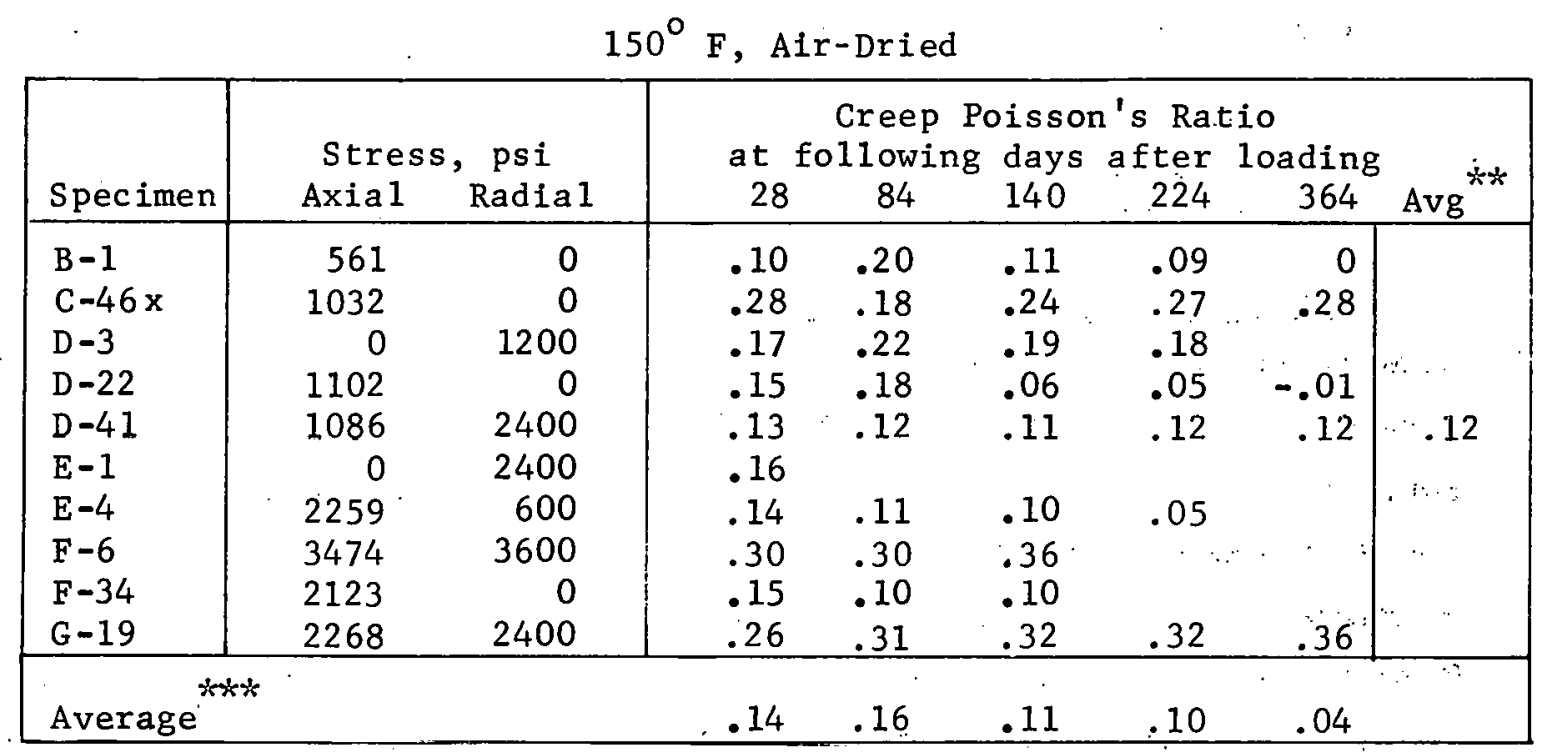

* Specimens which failed or had improperly functioning gages were" excluded. $* *$

Average over the entire test period for all environmental test conditions except those loaded hydrostatically and those in which oil penetrated.

$* * *$ Averages for all specimens except those loaded hydrostatically and those which oil penetrated.

$x$ Radial pressure reduced to zero shortly after loading due to oil leak in the specimen. 
average creep Poisson's ratio throughout the test period was 0.16 , which was approximately 65 percent of the average elastic.Poisson's ratio.

(2) The creep Poisson's ratio for air-dried concrete was approximately 70 percent of the value for as-cast concrete.

(3) The magnitude of stress and the state of stress influenced creep Poisson's ratio although this influence was less at the higher temperature and for the air-dried concrete.

Long Term Creep Poisson's Ratio. Owing to the apparent errors associated with estimating shrinkage and ițs effect on the relatively small radial strains, it was difficult to obtain a reliable value for creep Poisson's ratio for specimens cured for 183 or 365 days and subjested to a uniaxial etrcec for a period of either 5.25 or 4.7 .5 years. The as-cast specimens exhibiter a gradual decrease in creep Poisson's ratio, with the values for specimen $\mathrm{H}-24$ becoming negative approximately 2.5 years after loading. The creep Poisson's ratio for air-dried specimen I-20 was essentially zero throughout the test period while creep Poisson's ratio for the air-dried specimen H-17 remained essentially constant at 0.08 . Nevertheless, it is felt that a definite Poisson's effect did occur throughout the 4.75 or 5.25 years under load, and it was concluded that creep Poisson's ratio is not time-dependent. At best, the values measured during the long-term tests are probably low since the results for specimens cured 90 days prior to loading indicated Lliat creep Polsson's ratio averaged about 0.16 , with values 364 days after loading ranging from 0.11 to 0.28 . Specimens $B-7$ and $B-19$ exhibited values in the lower portion of this range and it is these two specimens which were used for comparison purposes (Table 12).

\section{PREDICTION OF CREEP BEHAVIOR}

Since long-term creep tests are time consuming and creep tests on concrete subjected to multiaxial stress are much more difficult to conduct than uniaxial tests, it would be desirable to be able to estimate creep behavior of concrete without conducting tests or at least without conducting long-term triaxial tests. Such estimation is difficult as evidenced by the large number of interactions which were found to affect creep behavior.

The two different approaches used for estimating creep behavior were (1) regression equations involving stress, loading condition, temperature, 
curing history, and time; and (2) unit creep prediction equations, which require information from short-term uniaxial tests to predict multiaxial or long-term creep behavior.

Regression Equations

Two types of equations for predicting creep strains in plain concrete were developed by stepwise regression analyses. The first set of equations was developed from an orthogonal coding of a full factorial arrangement of treatments while the second set of more general equations was developed from all the data, which could not be orthogonally coded.

The multiple correlation coefficients for all equations were in excess of 0.99. The standard errors of estimate for the orthogonally coded equation were in the range of \pm 7 to \pm 9 microunits while the standard errors of estimate were in the range of \pm 10 to \pm 21 microunits for the more general equations. The equations along with the conditions for which these equations were developed are contained in Ref 11 .

Unit Creep Function Equations.

A second approach, or technique, was developed to estimate long-term behavior of concrete subjected to triaxial stress conditions from short-term uniaxial creep tests. The development of the unit creep function and the predictive equations is completely described in Ref 1 . The unit creep function is expressed in the form

$$
F(t, \tau)=K\left(1-e^{-\alpha t^{\beta}}\right)
$$

where

$$
\begin{aligned}
& t=\text { time after loading, } \\
& \mathrm{l}=\text { age at luadiuy, } \\
& \mathrm{K}, \alpha, \text { and } \beta=\text { constants. }
\end{aligned}
$$

In order that this function could be used for prediction purposes, it was necessary to evaluate the constants $K, \alpha$, and $\beta$ and to estimate a value for creep Poisson's ratio $\nu_{r}$ from uniaxial test results. These 
relationships are then substituted into conventional strain-stress equations in place of the short-term elastic constant.

Unit Creep Function. The specimen conditions studied were as-cast and air-dried, both at $75^{\circ} \mathrm{F}$ and $150^{\circ} \mathrm{F}$. All specimens were loaded at the age of 90 days, and, therefore, the effect. of the age at loading $\tau$ on rrep strains could not be included and was considered constant. Thus, the unit creep function becomes $F(t, 90)$.

The stress-creep strain-time relationships are obtained from uniaxial tests to determine the creep proportional limit. The assumption of linearity between stress and creep strain is valid only at stress levels less than the creep proportional limit; therefore, only creep strains resulting from these stress levels were used for unit creep function evaluation. The constants in the unit creep function were determined by fitting the creep strains per unit stress to the unit creep function (Eq 3.2) using a computer program for nonlinear curve fitting.

The stress-creep strain-time relationships for the as-cast and air-dried specimens are shown in Figs 29 through 32, respectively. The linearity of the stress-creep strain relationships for the as-cast specimens at $75^{\circ} \mathrm{F}$ (Fig 29) indicates that the maximum stress level of approximately 2200 psi was less than the proportional limit. For the as-cast specimens at $150^{\circ} \mathrm{F}$ (Fig 30) and the air-dried specimens at $75^{\circ} \mathrm{F}$ (Fig 31) the creep proportional 11mit was also judged to be approximately $2200 \mathrm{psi}$. In contrast, the creep proportional limit for the air-dried specimens at $150^{\circ} \mathrm{F}$ (Fig 32) appeared to be lower at a stress level of $1500 \mathrm{psi}$, which was approximately 23 percent of the 28-day unconfined compressive strength. In the latter case, however, data were available for only two stress levels (600 and $240 n$ nsi) since the data from the two specimens loaded at 1200 and 3600 psi were questionable due to equipment malfunction.

The unit creep function relationships for the four conditions are summarized in Table 14, and the unit creep function-time relationships are illustrated in Fig 33. In addition, Table 14 contains an estimate of the ultimate unit creep, which was assumed to occur at an infinite time after loading. It may be noted that in Fig 33 the unit creep strains for loading periods of less than a year were larger for $150^{\circ} \mathrm{F}$ than for $75^{\circ} \mathrm{F}$ and for the air-dried condition than for the as-cast. 


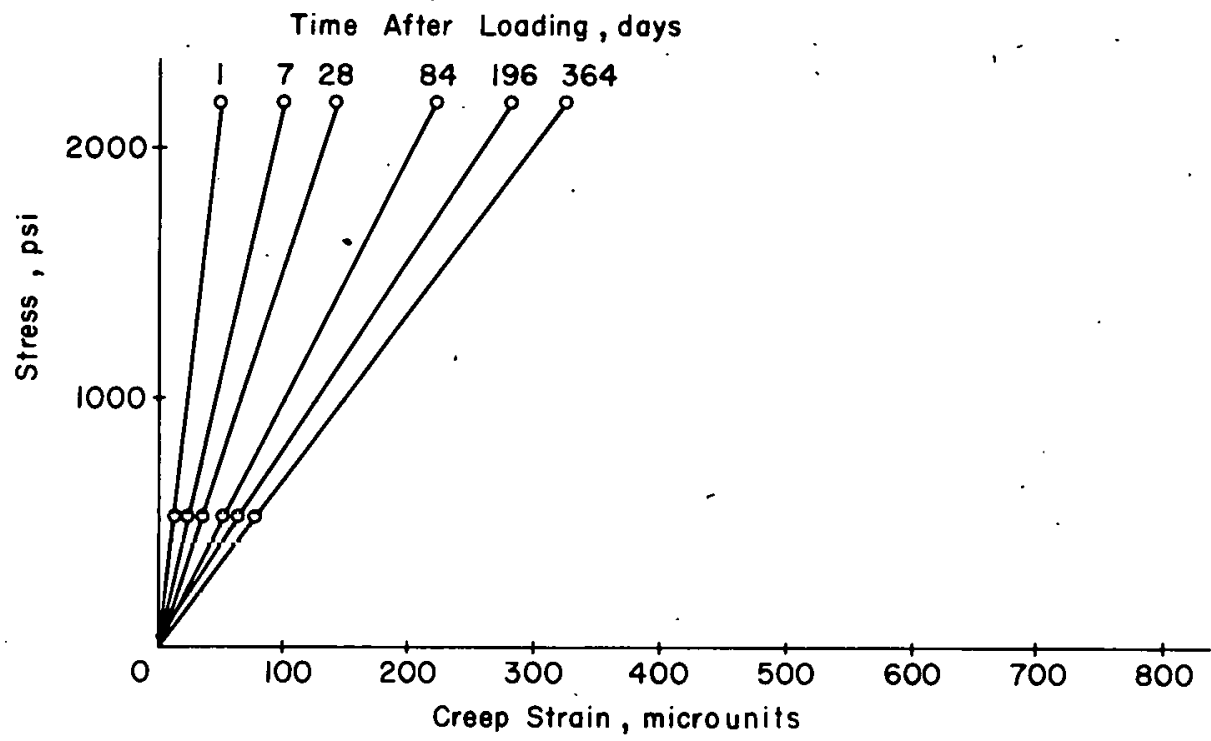

Fig 29. Stress-creep strain-time relationships for as-cast specimens at $75^{\circ} \mathrm{F}$.

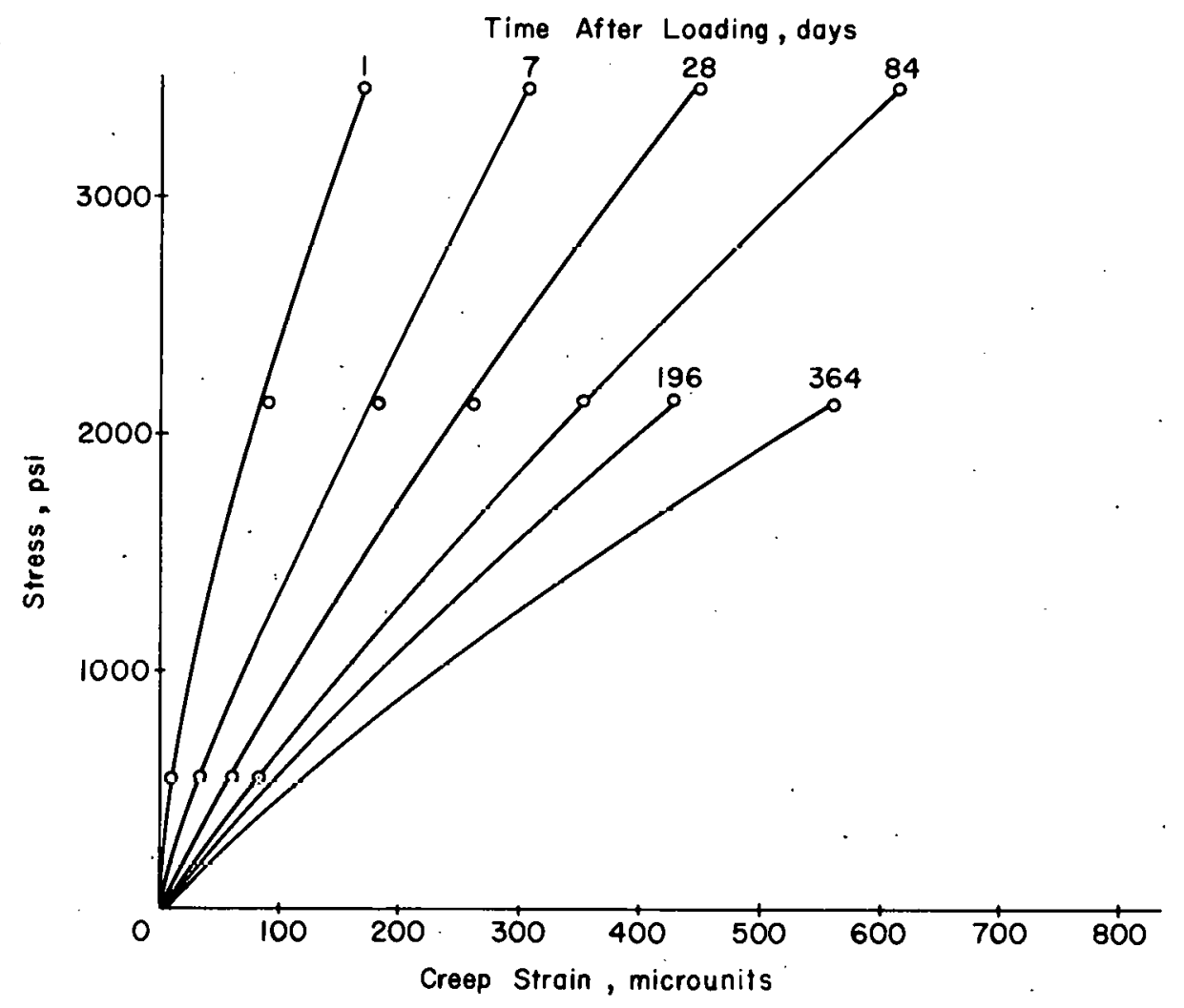

Fig 30. Stress-creep strain-time relationships for as-cast specimens at $150^{\circ} \mathrm{F}$. 


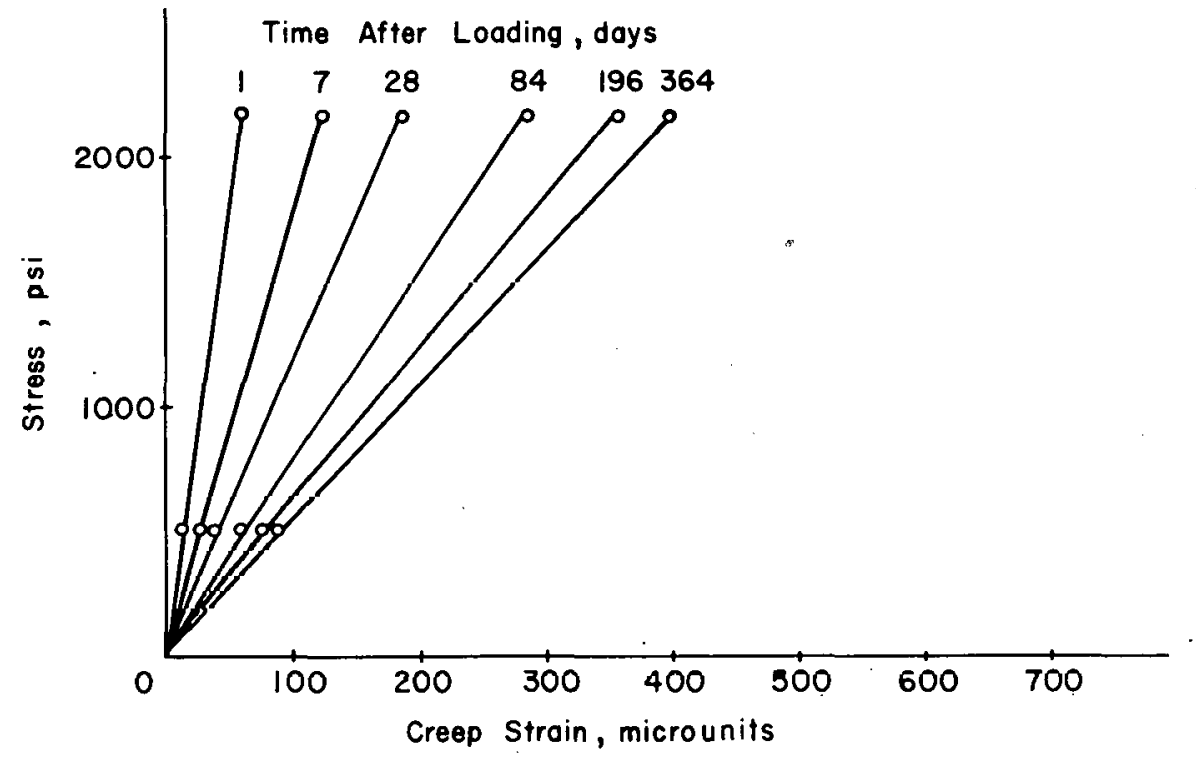

Fig 31. Stress-creep strain-time relationships for air-dried specimens at $75^{\circ} \mathrm{F}$.

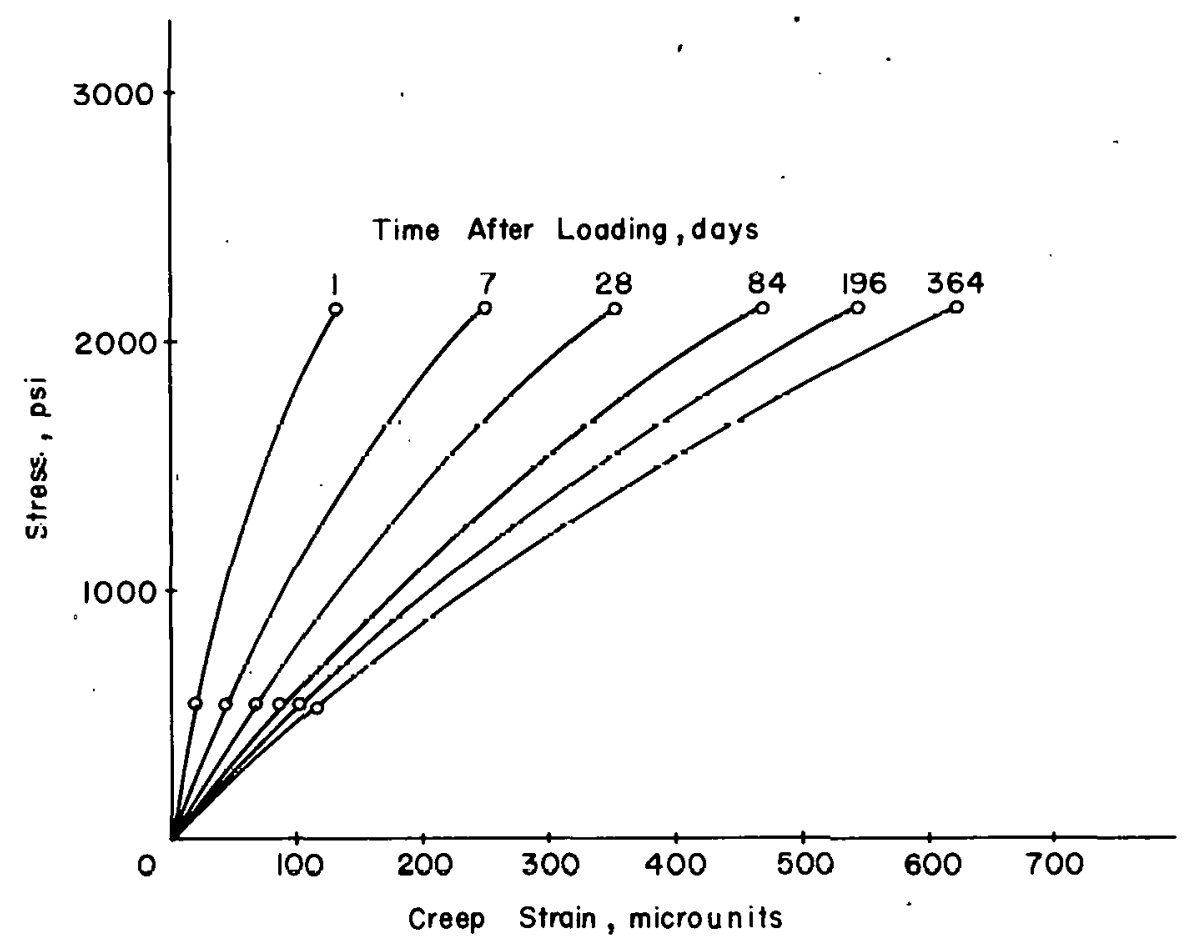

Fig 32. Stress-creep strain-time relationships for air-dried specimens at $150^{\circ} \mathrm{F}$. 
TABLE 14. UNIT CREEP FUNCTIONS AND ULTIMATE UNIT CREEP OBTAINED FROM UNIAXIALLY LOADED SPECIMENS UNDER VARIOUS TEST CONDITIONS

\begin{tabular}{|c|c|c|c|}
\hline \multicolumn{2}{|c|}{$\begin{array}{l}\text { Test } \\
\text { Conditions }\end{array}$} & $\begin{array}{c}\text { Unit Creep Function } F(t, 90), \\
\text { microunits/psi. }\end{array}$ & $\begin{array}{c}\text { Ultimate Unit Creep Strain, } \\
\text { microunits/psi }\end{array}$ \\
\hline \multirow{2}{*}{$\begin{array}{l}\Delta \\
0 \\
0 \\
1 \\
0 \\
8\end{array}$} & $\stackrel{\text { in }}{\text { in }}$ & $0.277\left(1-e^{-0.091 t^{0.358}}\right)$ & 0.277 \\
\hline & $\begin{array}{l}x_{1} \\
0 \\
0 \\
0\end{array}$ & $0.358\left(1-e^{-0.110 t^{0.385}}\right)$. & 0.358 \\
\hline \multirow{2}{*}{ 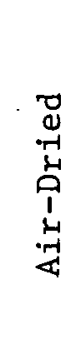 } & $i_{\text {in }}^{\text {in }}$ & $0.282\left(1-e^{-0.098 t^{0.407}}\right)$ & 0.282 \\
\hline & $\begin{array}{l}\text { L } \\
0 \\
0 \\
0\end{array}$ & $0.276\left(1-\mathrm{e}^{\left.-0.208 \mathrm{e}^{0.399}\right)}\right.$ & 0.276 \\
\hline
\end{tabular}

$t=$ time after loading, days 


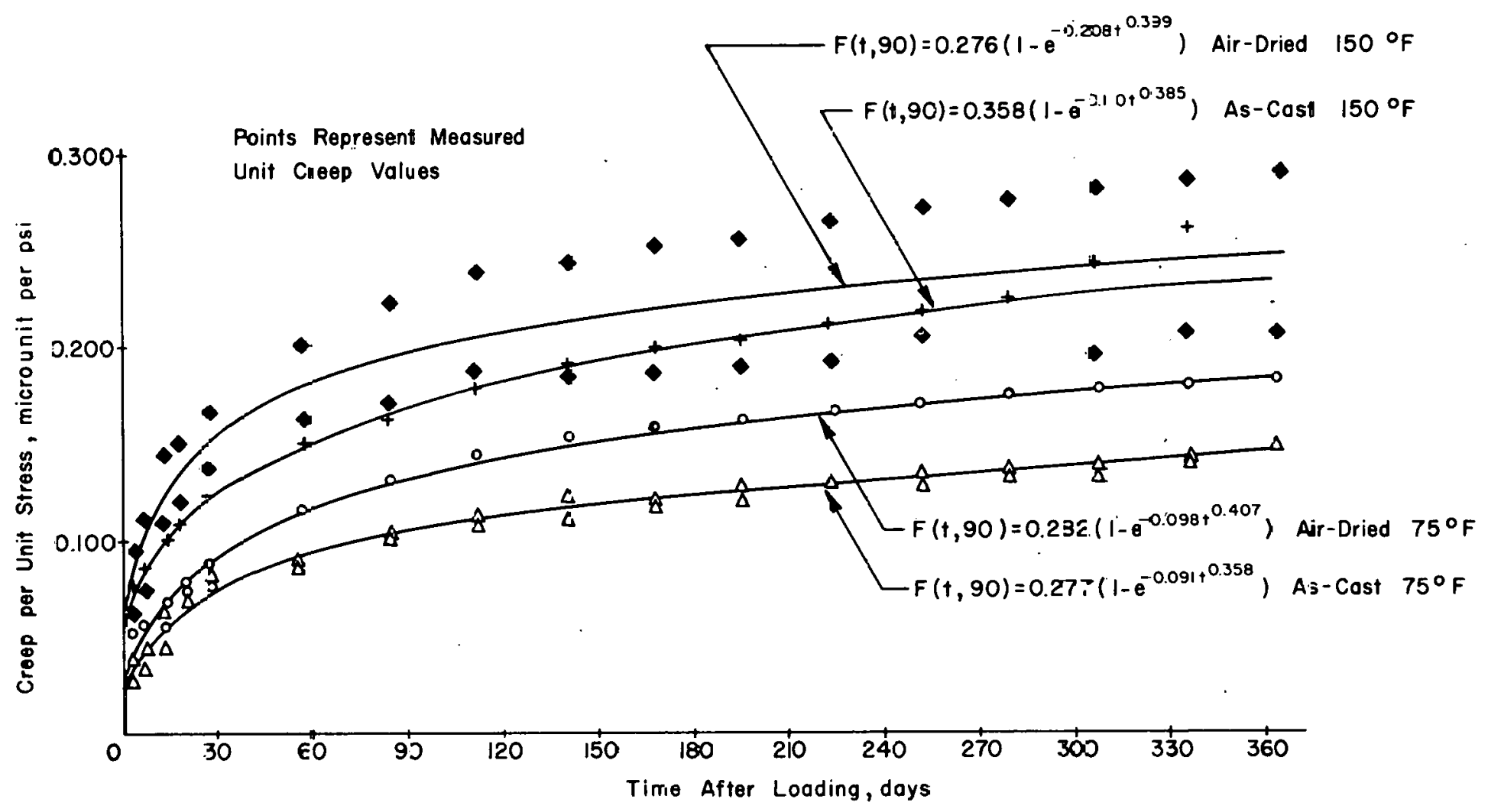

Fig 33. Unit creep functions for various test conditions. 
Creep Poisson's Ratio. In order to predict multiaxial creep strains, creep Poisson's ratios should be estimated from uniaxial tests. However, due to the fact that the number of uniaxial specimens was limited, values from biaxially loaded specimens were included. The average creep Poisson's ratios for the various uniaxial tests conducted on concrete cured for 90 days. were 0.150 and 0.149 for as-cast specimens at $75^{\circ} \mathrm{F}$ and $150^{\circ} \mathrm{F}$, respectively, and 0.108 and 0.140 for air-dried specimens at $75^{\circ} \mathrm{F}$ and $150^{\circ} \mathrm{F}$, respectively.

Inserting the appropriate creep Poisson's ratios and the relationships for the unit creep function into the strain-stress equations yields predictive equations for axial and radial creep strains for the four test conditions. These predictive equations are summarized in Table 15.

Evaluation of Creep Predictive Equations. In order to evaluate the accuracy of these predictive equations, it was necessary to compare predicted creep strains with actual creep strains measured experimentally. This was done in two parts. First, creep strains resulting from loading times in excess of those associated with the data used in developing the equations were compared with predicted strains. Second, creep strains resulting from multiaxial states of stress were compared with predicted values.

Since time under load in this investigation generally did not exceed 12 months, predicted creep strains were compared with creep strain data reported by Neville (Ref 12) for test conditions similar to conditions in this investigation. Creep strains after two years and five years under load were reported to be approximately 14 and 20 percent larger than the creep strains after one year. Assuming the creep strains at one year to be unity the predicted creep strains for uniaxially loaded specimens yield the results shown in Table 16. Examination of these results indicates a favorable comparison with those reported by Neville.

For the specimens cured for 183 days, the axial creep strains for the as-cast and air-dried specimens after 5 years under load were 1.48 and 1.32 times those which occurred during the first year. These values are essentially equal to the values predicted from the 90-day specimens, indicating that the prediction method is relatively accurate, except that the curing periods were different.

The accuracy and validity of the prediction equations were also evaluated by comparing predicted creep strains with experimentally measured results. 
TABLE 15. UNIT CREEP PREDICTIVE EQUATIONS

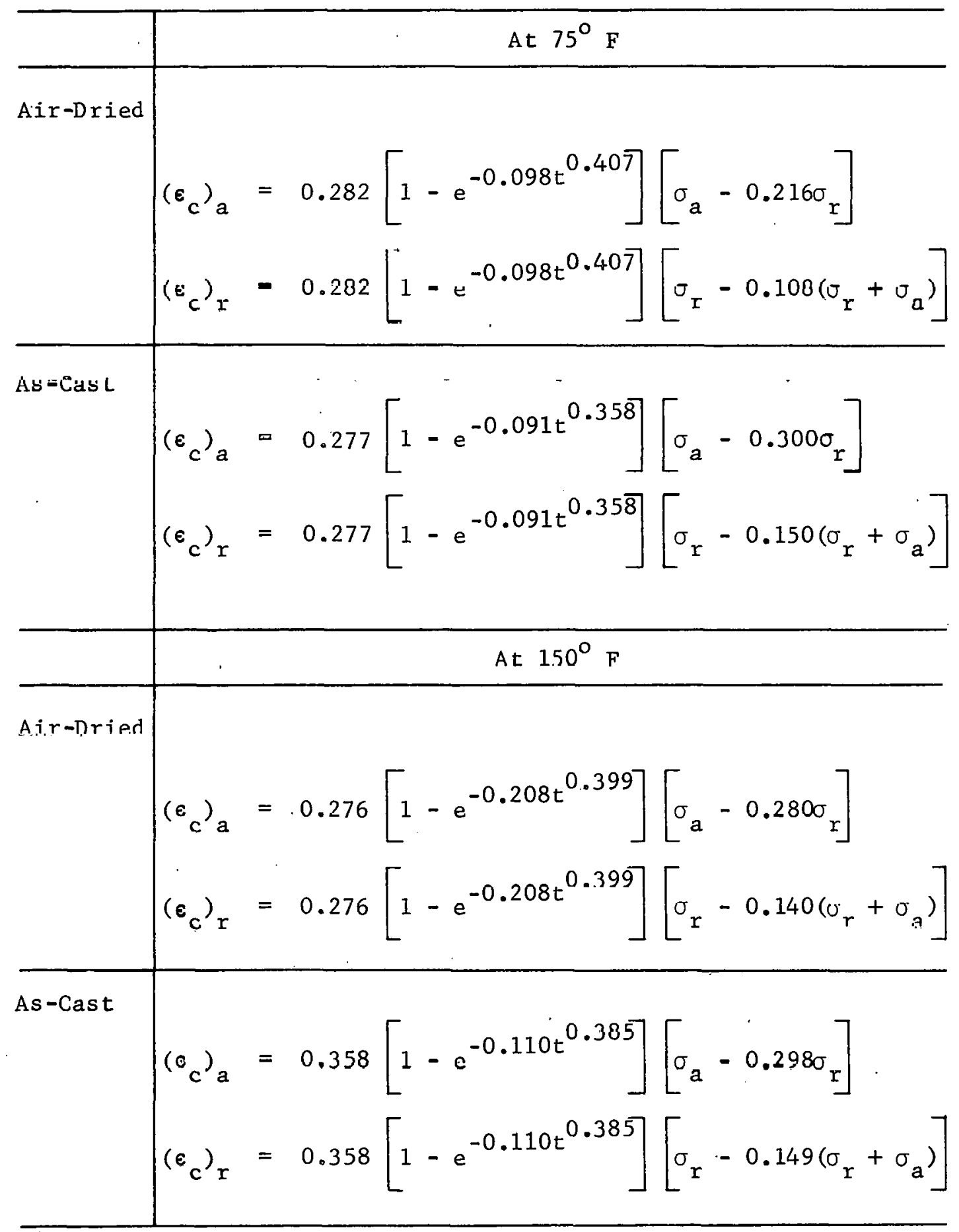

$\sigma_{a}=$ axial stress, psi

$\sigma_{r}=$ radial stress, psi

$t=$ time after loading, days $\left(\varepsilon_{c}\right)_{a}=$ creep strain in axial direc-

$\left(\epsilon_{c}\right)_{r}=$ creep strain in radial direc- 
TABLE 16. RATIO OF LONG TERM AND ONE-YEAR CREEP

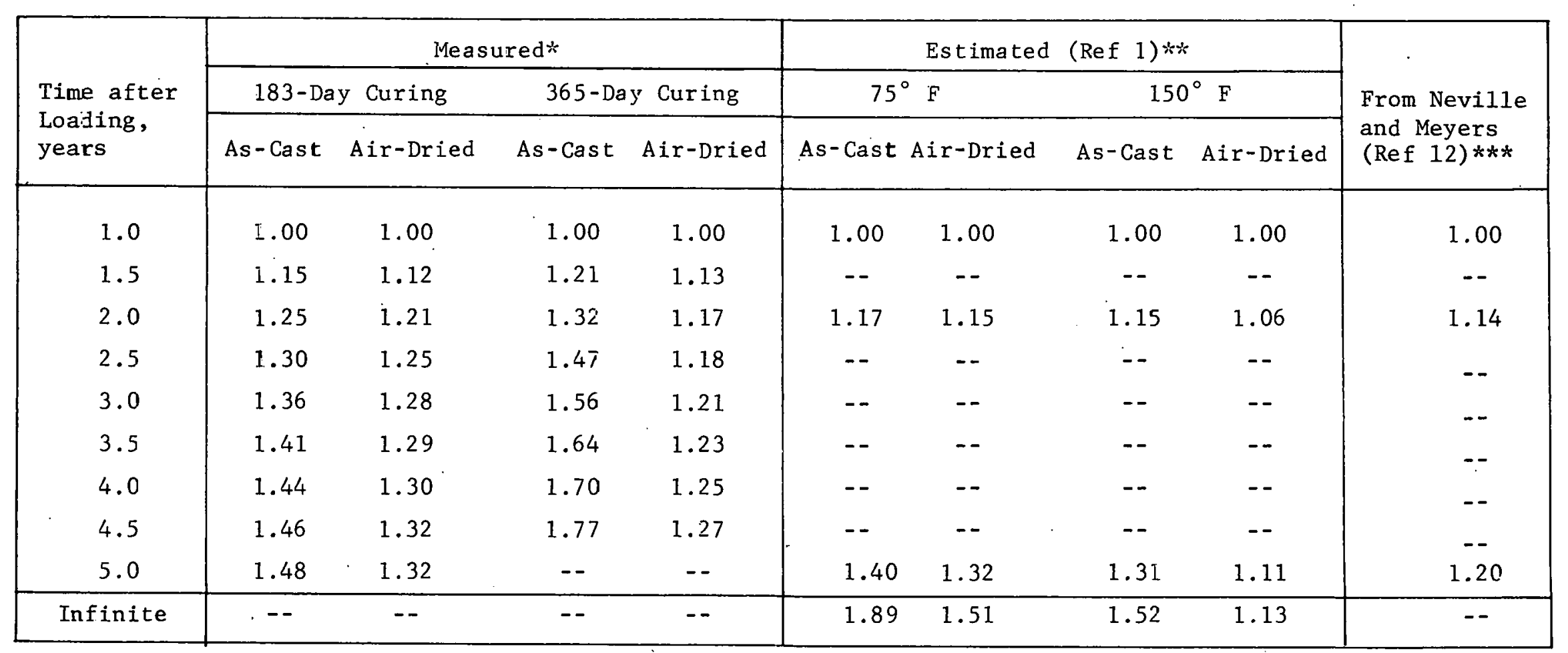

*Measured from axial strains from specimens loaded with a uniaxial stress of 2400 psi. *Es Eimated from uniexially loaded specimens cured 90 days before loading; $75^{\circ} \mathrm{F}$ and 60 percent relative humidity. $* * * 70^{\circ} \mathrm{F}$ and 50 percent relative humidity. 
Creep strains were predicted for the test conditions and stress levels utilized in the experimental portion of this investigation involving specimens cured for 90 days. Figures 34 through 37 compare the predicted and measured radial and axial creep strains at $1,7,14,28,84,168$, and 364 days after loading for the four combinations of curing histories and testing temperatures. The predicted and measured creep strain-time relationships for individual specimens are shown in $\operatorname{Ref} 1$.

The results shown in Figs 34 through 37 indicate that at stress levels less than the creep proportional limit, the creep prediction equations are relatively accurate. Nevertheless, with che exceplion of the air-dried specimens at $75^{\circ} \mathrm{F}$, the predicted creep strains generally were larger than the measured creep strains. The difference was essentially a constant percentage of the measured strain for each test condition.

Since many reasons for the differences could be suggested, it was felt that additional tests were needed. However, additional tests could not be conducted as a part of the investigation. Thus, the unit creep predictive equations were modified.

Modification of Equations. In view of the fact that the unit creep predictive equations systematically overestimated creep strains in three of the four test condiefons, all lour equations were modified hy multiplying the $\mathrm{K}$ constant (Eq 3.2 ) by the ratio of the slope of the 45 degree 1 Ine and the line of best fit. Thus, the predictive equations for as-cast and air-dried conditions at $75^{\circ} \mathrm{F}$ and $150^{\circ} \mathrm{F}$, shown in Table 15 , were multiplied by a factor of $0.961,1.098,0.880$, or 0.922 . The relationships betweell the measured creep strains and the creep strains predlcted using the modifled equations are graphically illustrated In Figs 38 through 41 . In these figures it can be seen that the predicted strains are very close to the measured strains for the conditions and measurements made in the experimental portion of this investigation. The standard errors of estimate for as-cast and air-dried specimens at $75^{\circ} \mathrm{F}$ and $150^{\circ} \mathrm{F}$ loaded at stresses lower than the creep proportional limit were $13,21,35$, and 31 microunits.

These modified equations adequately predict the creep strains measured for specimens loaded at stress levels below the creep proportional limit in this investigation; however, this does not mean that they are necessarily adequate for application to other conditions. 


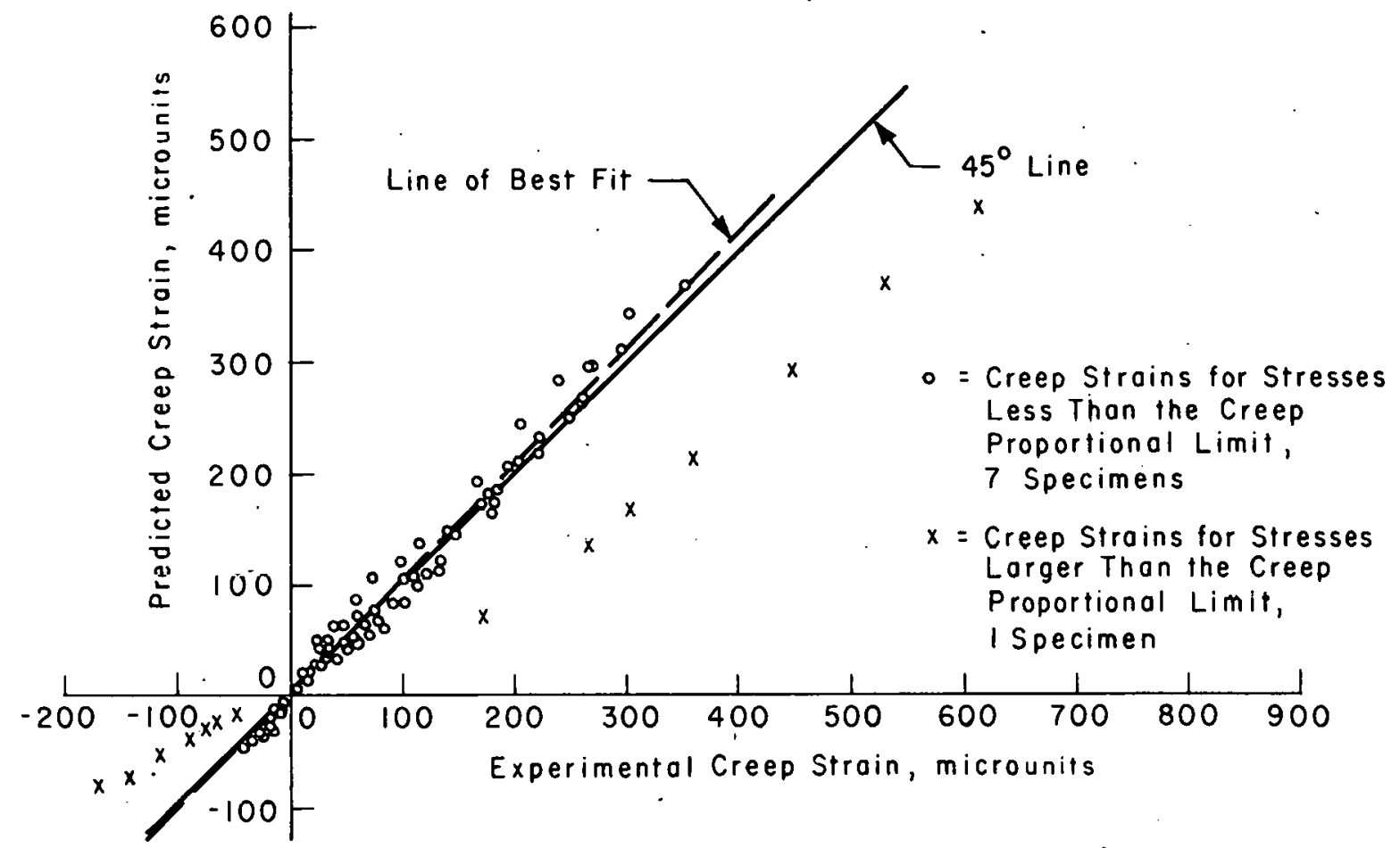

Fig 34. Predicted and experimental creep strains for triaxially loaded as-cast specimens at $75^{\circ} \mathrm{F}$.

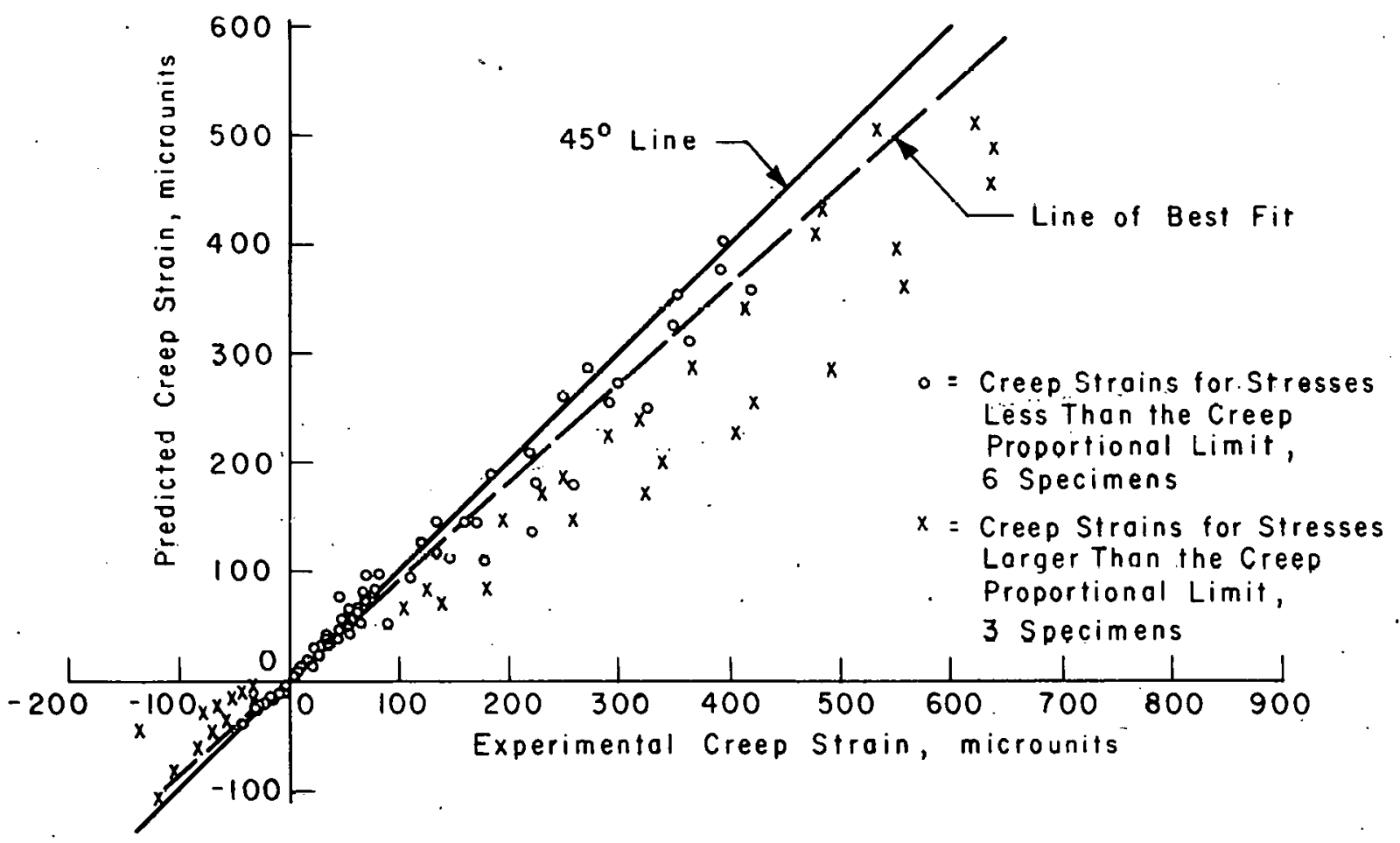

Fig 35. Predicted and experimental creep strains for triaxially loaded air-dried specimens at $75^{\circ} \mathrm{F}$. 


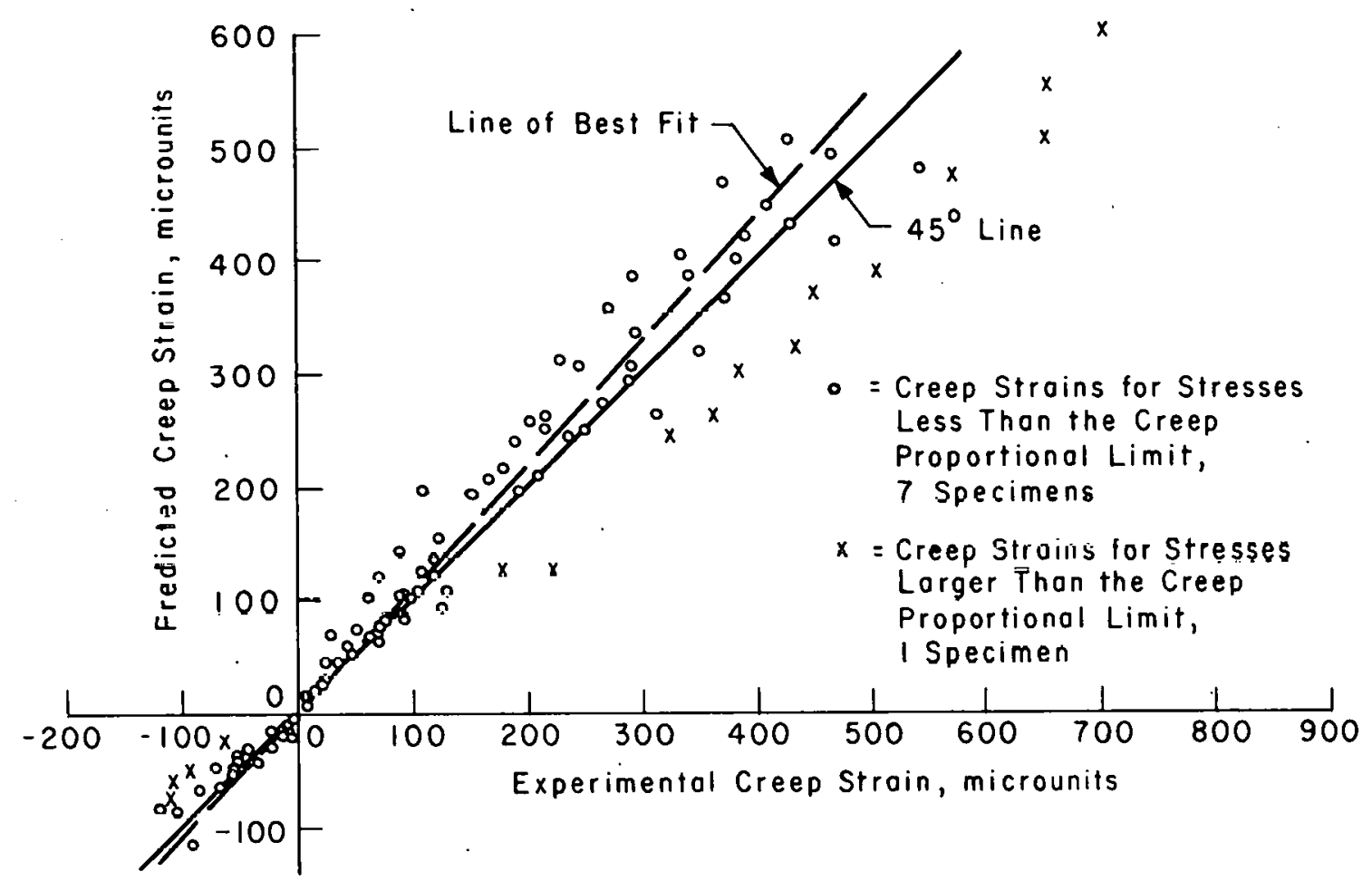

Fig 36. Predicted and experimental creep strains for triaxially loaded as-cast specimens at $150^{\circ} \mathrm{F}$.

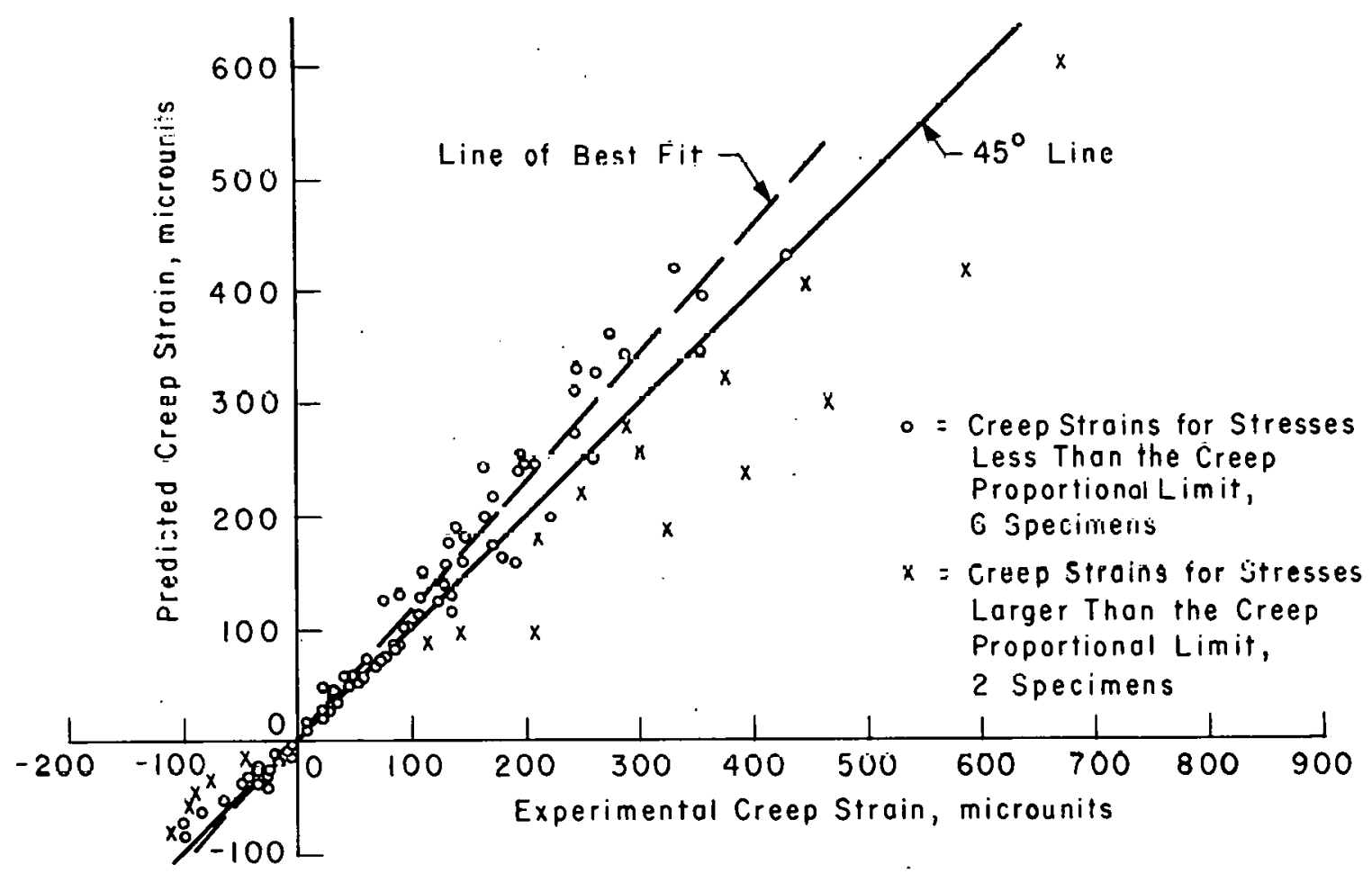

Fig 37. Predicted and experimental creep strains for triaxially loaded air-dried specimens at $150^{\circ} \mathrm{F}$. 


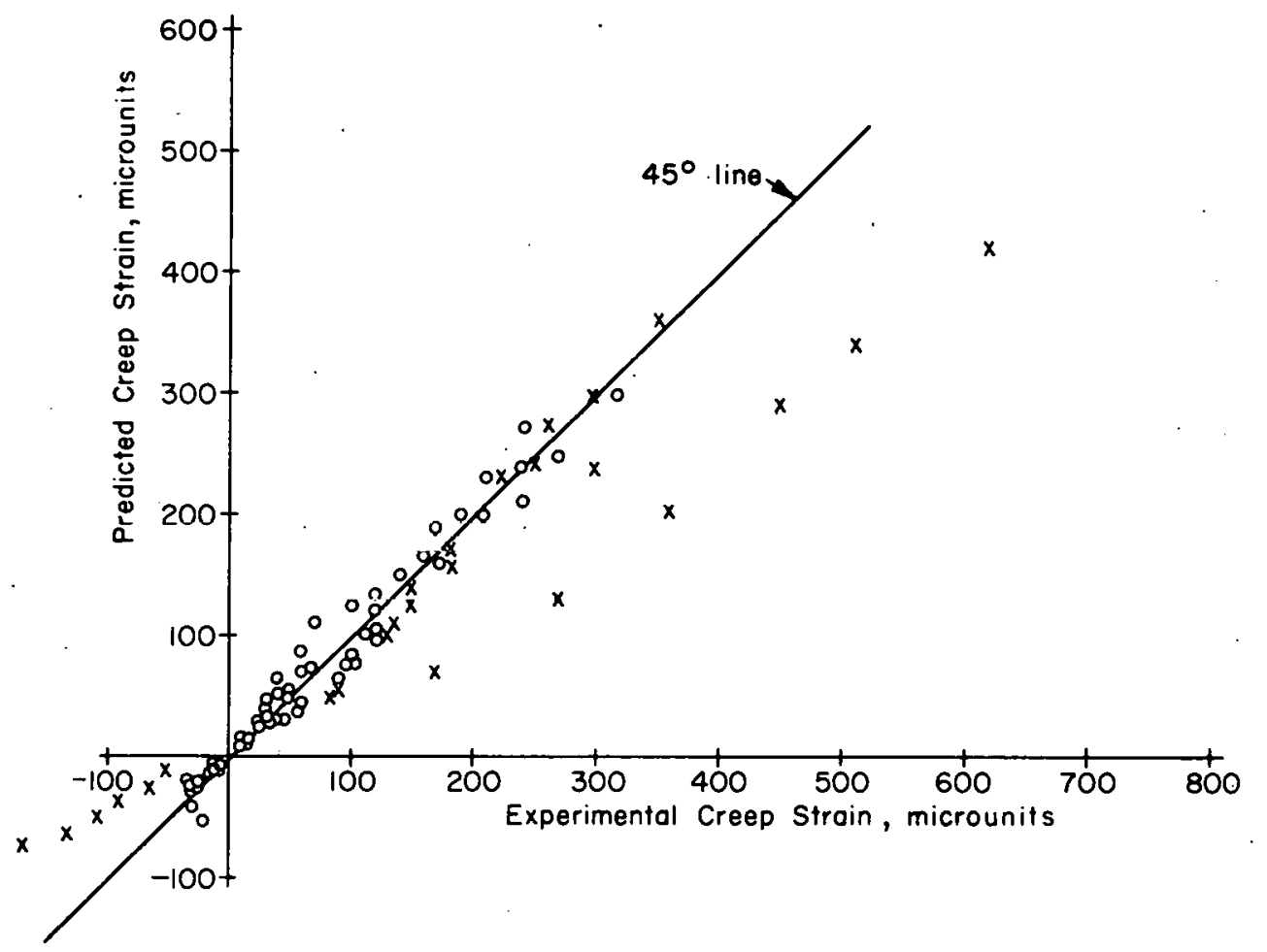

Fig 38. Experimental and predicted creep strains from modified unit creep prediction equations for triaxially loaded as-cast specimens at $75^{\circ} \mathrm{F}$.

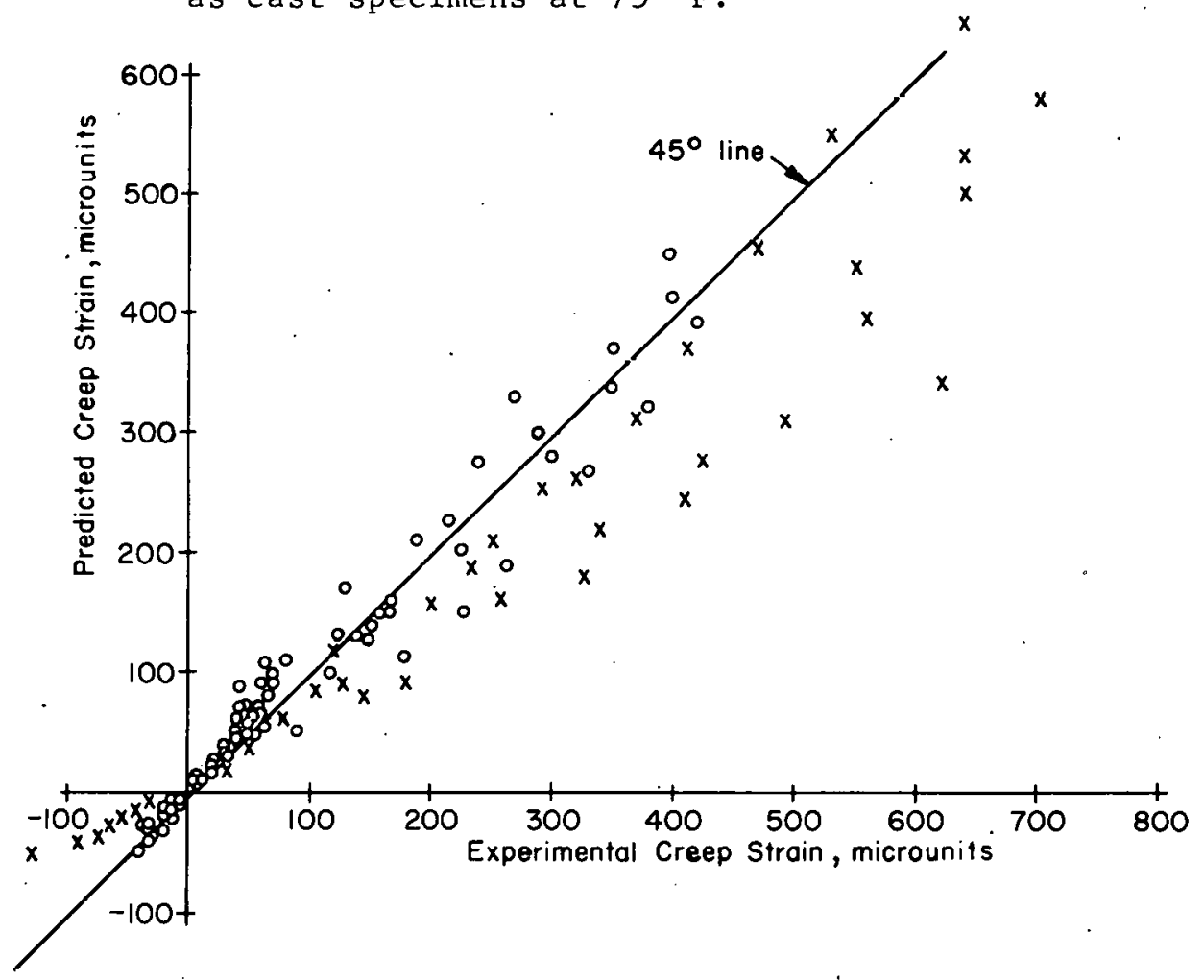

Fig 39. Experimental and predicted creep strains from modified unit creep prediction equations for triaxially loaded air-dried specimens at $75^{\circ} \mathrm{F}$. 


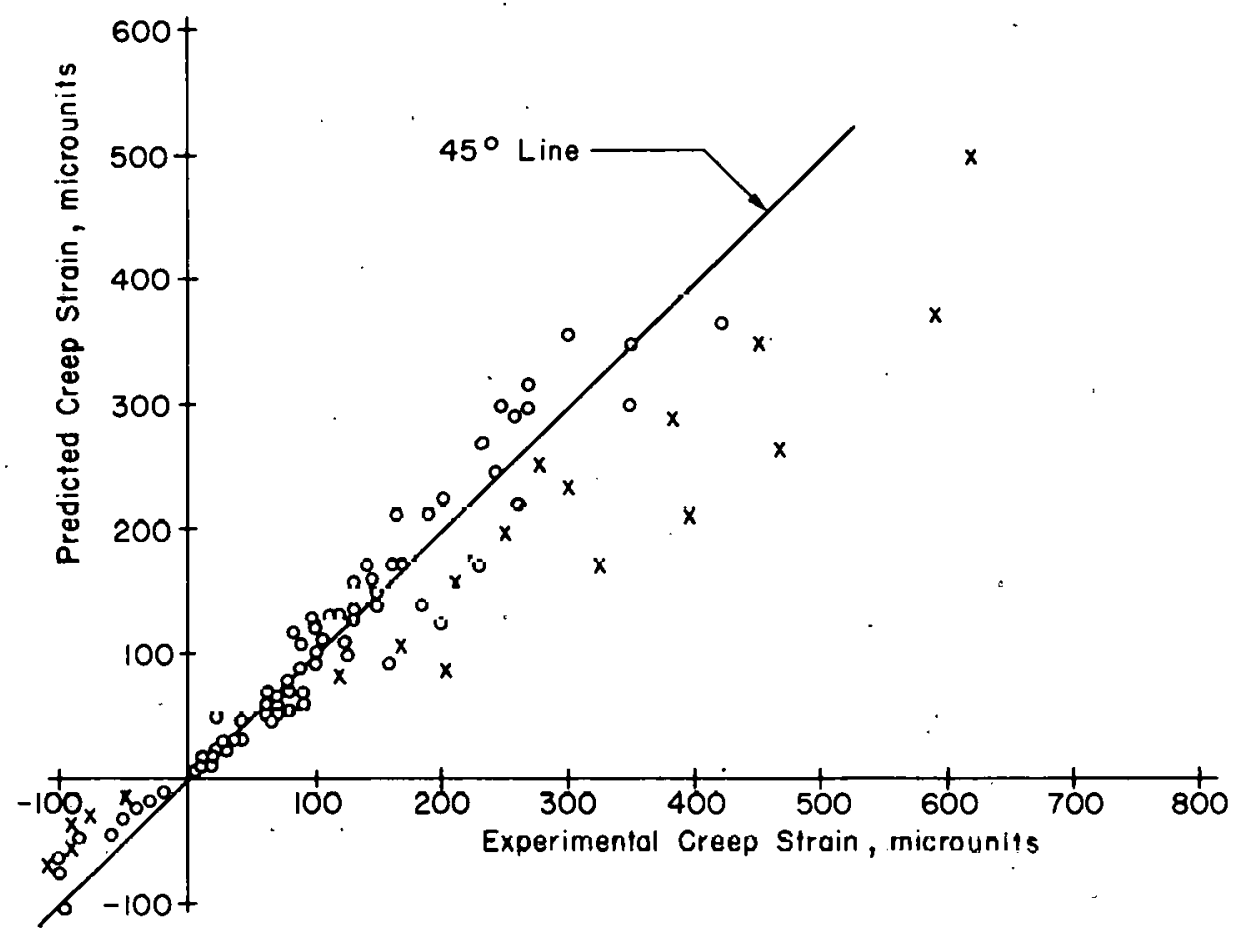

Fig 40. Experimental and predicted creep strains from modified unit creep prediction equations for triaxially loaded as-cast specimens at $150^{\circ} \mathrm{F}$.

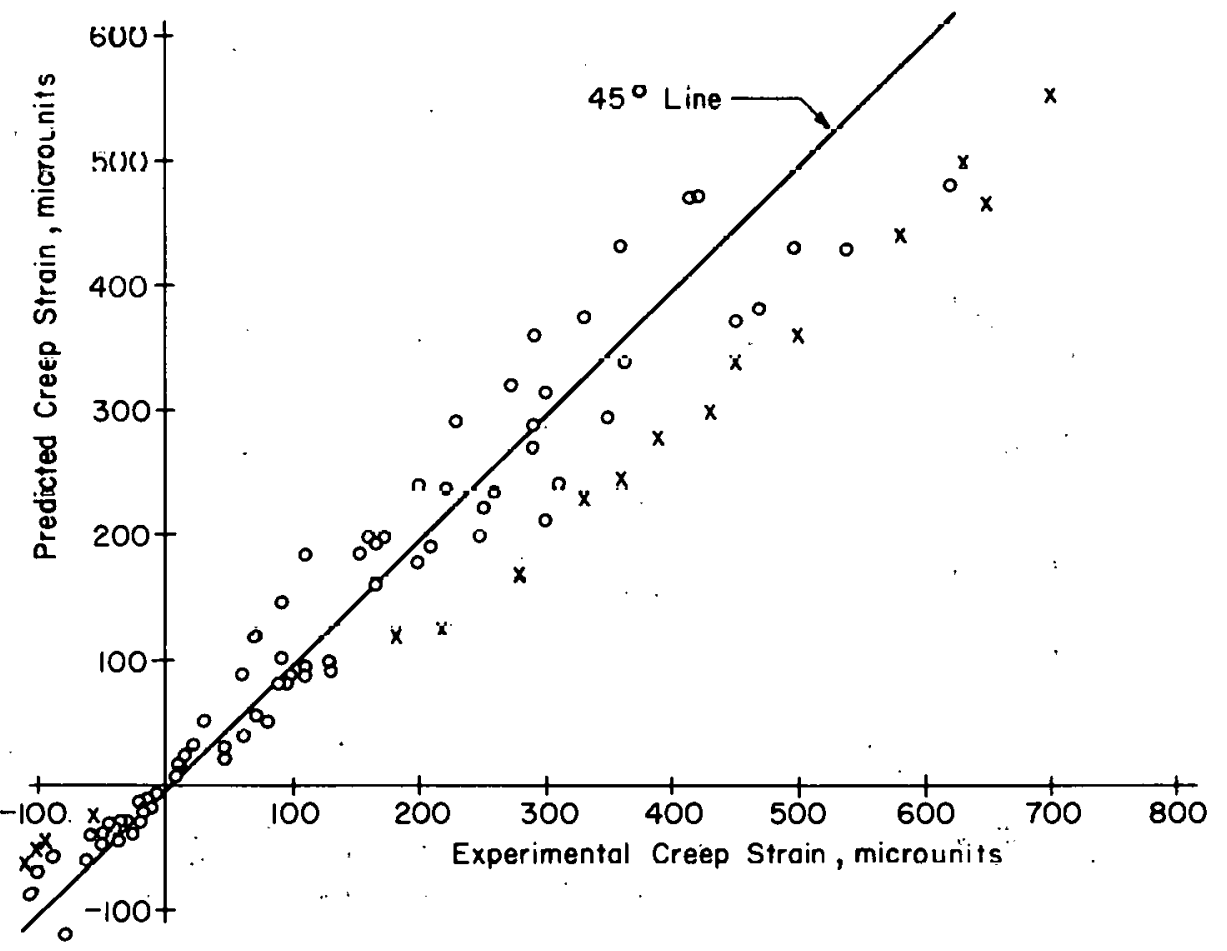

Fig 41. Experimental and predicted creep strains from modified unit creep prediction equations for triaxially loaded air-dricd spccimcns at $150^{\circ} \mathrm{F}$. 
RECOVERY AFTER THE REMOVAL OF LOADS

The specimens cured for 90 days were subjected to loads for a period of 12 months, after which strain measurements were continued for an additional five months. The specimens cured for $183^{\circ}$ or 365 days were subjected to load for a period of 5.25 or 4.75 years, respectively, followed by a 77-day recovery period. These recovery strains were divided into instantaneous elastic recovery strains and creep recovery strains.

The instantaneous elastic recovery strain was determined by taking strain readings just prior to and immediately after the loads were removed. Creep recovery strain was determined by considering that the total strain less the average shrinkage strain immediately after unloading was the zero reference point. Values of both instantaneous and creep recovery strains at the end of the recovery period are shown in Table 17 . The relationships between creep recovery'strain and time for individual 90-day specimens are shown in Figs 42 through 49. Curves representing the total strain less the average shrinkage strain from the time of unloading up to five months later are shown in Appendices $B$ through $E$ of Ref 2 for specimens having at least one gage functioning properly at the time of unloading.

Creep recovery occurred at a high rate in the early weeks after unloading, then almost leveled off in about one month and it generally was found that a recovery period of five months is more than adequate to obtain reasonable estimates of the maximum creep recovery.

A detailed evaluation of the recovery characteristics of the specimens cured for 90 days is contained in Ref 2 , and a preliminary evaluation in Ref 11 .

\section{Factors Affecting Recovery.}

Temperature. No definite effect of temperature on the instantaneous recovery strain could be established. In some cases the instantaneous recovery strains were larger at $150^{\circ} \mathrm{F}$ than at $75^{\circ} \mathrm{F}$ while in other cases the instantaneous recovery strains were smaller at $150^{\circ} \mathrm{F}$. The differences, however, generally were quite small. Hence, it was concluded that temperature did not affect the instantaneous recovery of the concrete in this investigation. Previous work, reviewed in Ref 2 , indicated that creep recovery, defined as the recovery in excess of the instantaneous recovery at the time of unloading, 
TABLE 17. INS TANTANEOUS RECOVERY AND CREEP RECOVERY STRAINS*

\begin{tabular}{|c|c|c|c|c|c|c|c|c|c|}
\hline \multirow{2}{*}{$\begin{array}{c}\text { Temperature, } \\
{ }^{\circ} \mathrm{F}\end{array}$} & \multirow{2}{*}{$\begin{array}{l}\text { Curing } \\
\text { History }\end{array}$} & \multirow{2}{*}{$\begin{array}{l}\text { Curing } \\
\text { Period, } \\
\text { days }\end{array}$} & \multirow[b]{2}{*}{ Specimen } & \multicolumn{2}{|c|}{ Stress, psi } & \multicolumn{2}{|c|}{$\begin{array}{c}\text { Instantaneous } \\
\text { Recovery } \\
\varepsilon_{\text {ir }} \\
\text { microunits }\end{array}$} & \multicolumn{2}{|c|}{$\begin{array}{c}\text { Creep Recovery } \\
\epsilon_{\mathrm{cr}}{ }^{* *} \\
\text { micruunits }\end{array}$} \\
\hline & & & & Axial ${ }^{\prime \prime}$ & Radial & Axial & Radia 1 & Axial & Radia 1 \\
\hline \multirow{6}{*}{$\approx$} & \multirow[t]{3}{*}{$\begin{array}{l}n \\
0 \\
0 \\
\vdots \\
1 \\
\vdots \\
4\end{array}$} & 90 & $\begin{array}{l}E-39 \\
B-7 \\
F-13 \\
H-22 \\
E-5 \\
C-23 \\
C-16 \times \\
D-26 \\
B-41 \\
F-9 \\
G-35 \\
D-31\end{array}$ & $\begin{array}{r}600 \\
2400 \\
0 \\
0 \\
600 \\
2.400 \\
1200 \\
3600 \\
1200 \\
2400 \\
600 \\
3600 \\
\end{array}$ & $\begin{array}{c}0 \\
0 \\
600 \\
3600 \\
600 \\
600 \\
1200(0) \\
1300 \\
2400 \\
2400 \\
3600 \\
3600 \\
\end{array}$ & $\begin{array}{r}-85 \\
-401 \\
55 \\
303 \\
-39 \\
-2.98 \\
-166 \\
-495 \\
-178 \\
-181 \\
233 \\
-275\end{array}$ & $\begin{array}{r}23 \\
94 \\
-74 \\
-548 \\
-53 \\
18 \\
43 \\
-1 \\
-194 \\
-199 \\
-482 \\
-322\end{array}$ & $\begin{array}{l}-8 \\
-68 \\
8 \\
66 \text { 非 } \\
-16 \\
-65 \\
-38 \\
-89 \text { 将 } \\
-40 \\
-51 \\
41 \\
-49\end{array}$ & $\begin{array}{c}6 \\
19 \\
-21 \\
-102 \neq k \\
-16 \\
2 \\
7 \\
04 k \\
-33 \\
-54 \\
-121 \\
-69\end{array}$ \\
\hline & & 183 & $\begin{array}{l}\mathrm{H}-45 \\
\mathrm{H}-34\end{array}$ & $\begin{array}{r}600 \\
2400\end{array}$ & $\begin{array}{l}0 \\
0\end{array}$ & $\begin{array}{r}-72 \\
-429\end{array}$ & $\begin{array}{l}32 \\
95\end{array}$ & $\begin{array}{r}-8 \\
-45\end{array}$ & $\begin{array}{r}0 \\
24\end{array}$ \\
\hline & & 365 & $\begin{array}{l}\mathrm{H}-5 \\
\mathrm{H}-24\end{array}$ & $\begin{array}{r}600 \\
2400\end{array}$ & $\begin{array}{l}0 \\
0\end{array}$ & $\begin{array}{r}-73 \\
-395\end{array}$ & $\begin{array}{l}21 \\
91\end{array}$ & $\begin{array}{l}-5 \\
-45\end{array}$ & $\begin{array}{l}4 \\
8\end{array}$ \\
\hline & \multirow[t]{3}{*}{ 品 } & 90 & $\begin{array}{l}E-40 \\
B-19 \\
F-12 \\
H-14 \\
E-13 \\
C-11 \\
C-17 \\
D=44 \\
B-42 \\
F-30 \\
G-30 \\
D-40\end{array}$ & $\begin{array}{r}600 \\
2400 \\
0 \\
0 \\
600 \\
2400 \\
1200 \\
3600 \\
1200 \\
2400 \\
600 \\
3600 \\
\end{array}$ & $\begin{array}{r}0 \\
0 \\
600 \\
3600 \\
600 \\
600 \\
1200 \\
1200 \\
2400 \\
2400 \\
3600 \\
3600\end{array}$ & $\begin{array}{c}-100 \\
-433 \\
53 \\
316 \\
-51 \\
-385 \\
-70 \\
- \\
-153 \\
-184 \\
214 \\
-315\end{array}$ & $\begin{array}{r}27 \\
103 \\
-81 \\
- \\
-55 \\
15 \\
-95 \\
-13 \\
-222 \\
-241 \\
- \\
-382\end{array}$ & $\begin{array}{c}-16 \\
-88 \\
1 \\
64 \| \# \\
-16 \\
-91 \\
-24 \\
-131 \\
-10 \\
-67 \\
32 \\
-96\end{array}$ & $\begin{array}{l}-2 \\
16 \\
-23 \\
-111 \# \\
-16 \\
-16 \\
-23 \\
-26 \\
-34 \\
-82 \\
-118 \\
-118\end{array}$ \\
\hline & & 183 & $\begin{array}{l}I-39 \\
I-20\end{array}$ & $\begin{array}{r}\text { bu0 } \\
2400\end{array}$ & $\begin{array}{l}0 \\
0\end{array}$ & $\begin{array}{r}-75 \\
-418\end{array}$ & $\begin{array}{l}21 \\
99\end{array}$ & $\begin{array}{r}-6 \\
-53\end{array}$ & $\begin{array}{l}10 \\
14\end{array}$ \\
\hline & & 365 & $\begin{array}{l}\mathrm{H}-31 \\
1 \mathrm{l}-17\end{array}$ & $\begin{array}{r}600 \\
2400\end{array}$ & $\begin{array}{l}0 \\
0\end{array}$ & $\begin{array}{l}-108 \\
-476\end{array}$ & $\begin{array}{r}17 \\
114\end{array}$ & $\begin{array}{r}-2 \\
-50\end{array}$ & $\begin{array}{r}7 \\
19\end{array}$ \\
\hline \multirow{2}{*}{ 옥 } & $\begin{array}{l}4 \\
n \\
0 \\
i \\
0\end{array}$ & 90 & $\begin{array}{l}B-4 \\
D-15 \\
F-33 \\
A=35 \\
C-12 \\
D-2 x \\
C-9\end{array}$ & $\begin{array}{r}600 \\
1200 \\
2400 \\
0 \\
1200 \\
1200 \\
2400\end{array}$ & $\begin{array}{c}0 \\
0 \\
0 \\
600 \\
1200 \\
2400(0) \\
2400\end{array}$ & 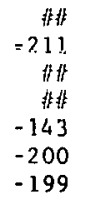 & 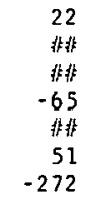 & $\begin{array}{r}\text { fly } \\
-72 \\
-59 \\
\text { fl } \\
-42 \\
-61 \\
-95\end{array}$ & 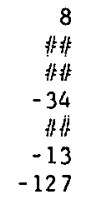 \\
\hline & 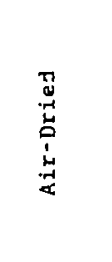 & 90 & $\begin{array}{l}B-1 \\
D=22 \\
F-34 \\
D-3 \\
E-4 \\
C-46 x \\
D-41 \\
G-19 \\
F-6\end{array}$ & $\begin{array}{r}600 \\
1200 \\
2400 \\
0 \\
2400 \\
1200 \\
1200 \\
2400 \\
3600\end{array}$ & $\begin{array}{c}0 \\
0 \\
0 \\
600 \\
600 \\
1200(0) \\
2400 \\
2400 \\
3600\end{array}$ & $\begin{array}{r}-96 \\
-231 \\
-431 \\
99 \\
-343 \\
-277 \\
3 \\
-188 \\
-295\end{array}$ & 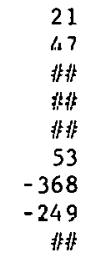 & $\begin{array}{r}-19 \\
-53 \\
-112 \\
\|k\| k \\
-118 \\
-86 \\
31 \\
-75 \\
-160\end{array}$ & 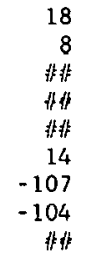 \\
\hline
\end{tabular}

* After 5 months for 90-day specimens; after 77 days for 183 and 365-day specimens.

\# Nominal axial stress.

$x$ Radial pressure reduced to zero shortly after initial loading.

t* Compression is positive and tension is negative.

F作 Gage failed or gage range was exceeded. 


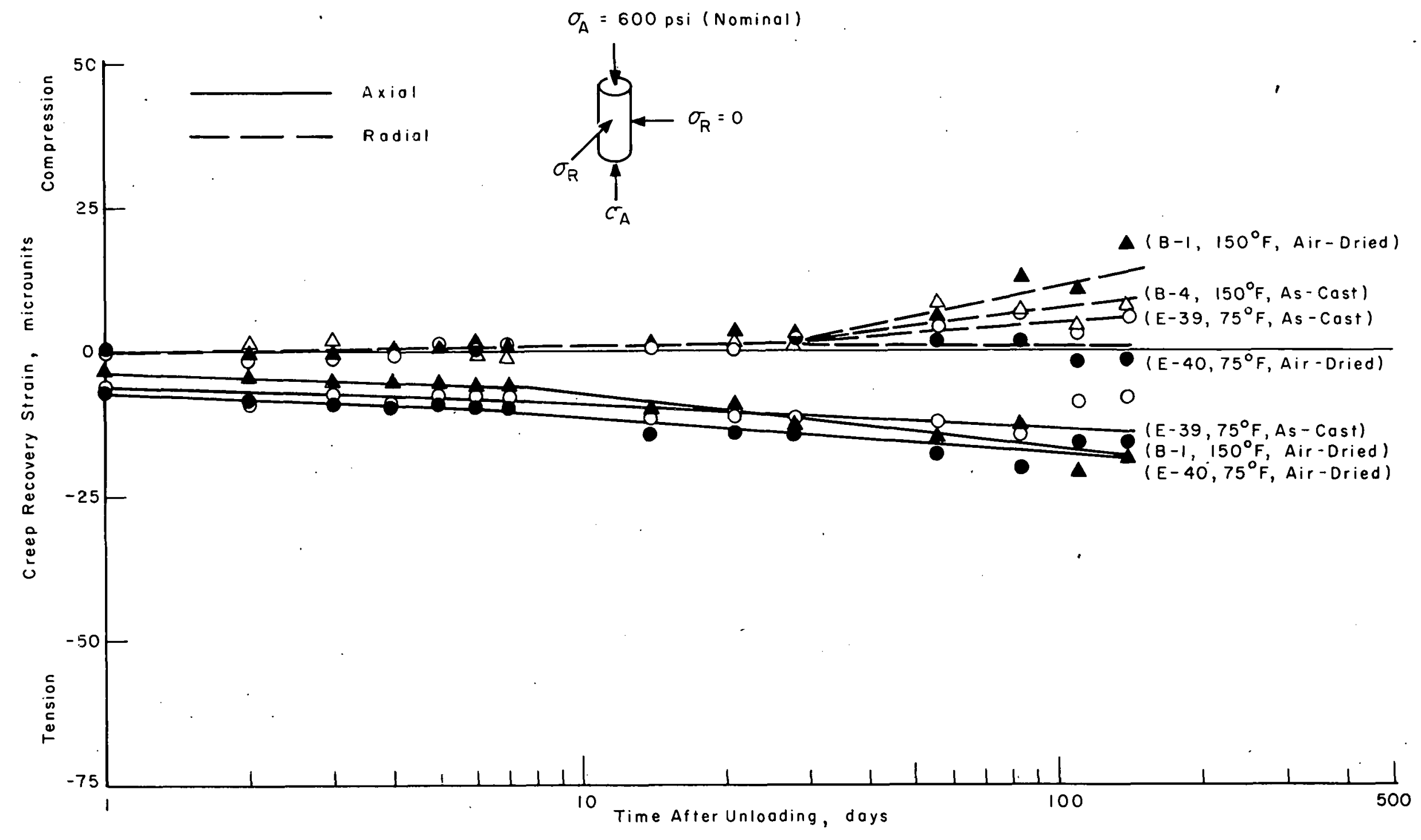

Fig 42. Effect of temperature and curing history on creep recovery for 90-day specimens loaded uniaxially at 600 psi. 


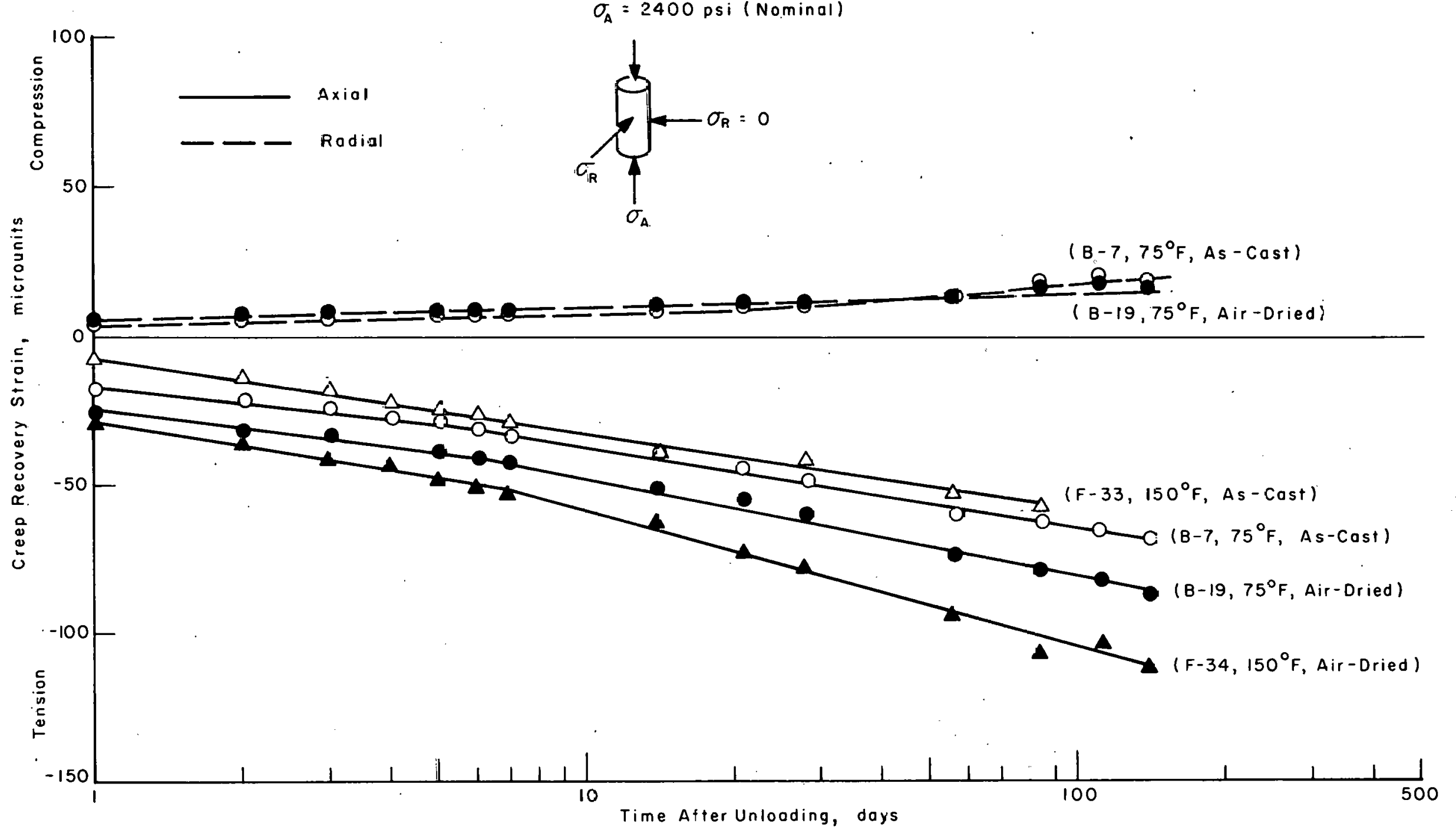

Fig 43. Efiect of temperature and curing history on cree? recovery for 90-day specímens loaded uniaxially at 2400 psi. 


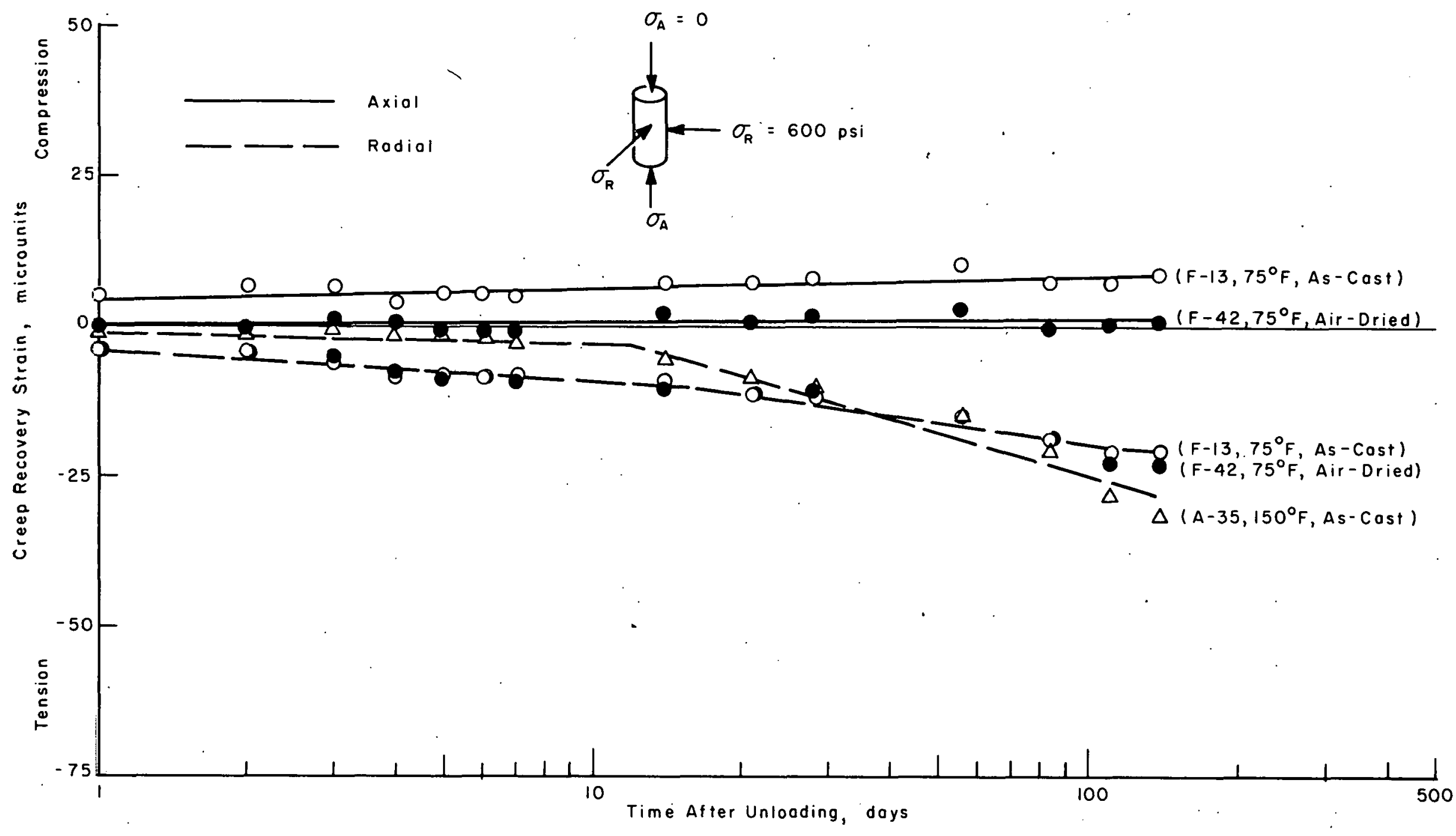

Fig 44. Effect of temperature and curing history on creep recovery for 90-day specimens loaded biaxially at $600 \mathrm{psi}$. 


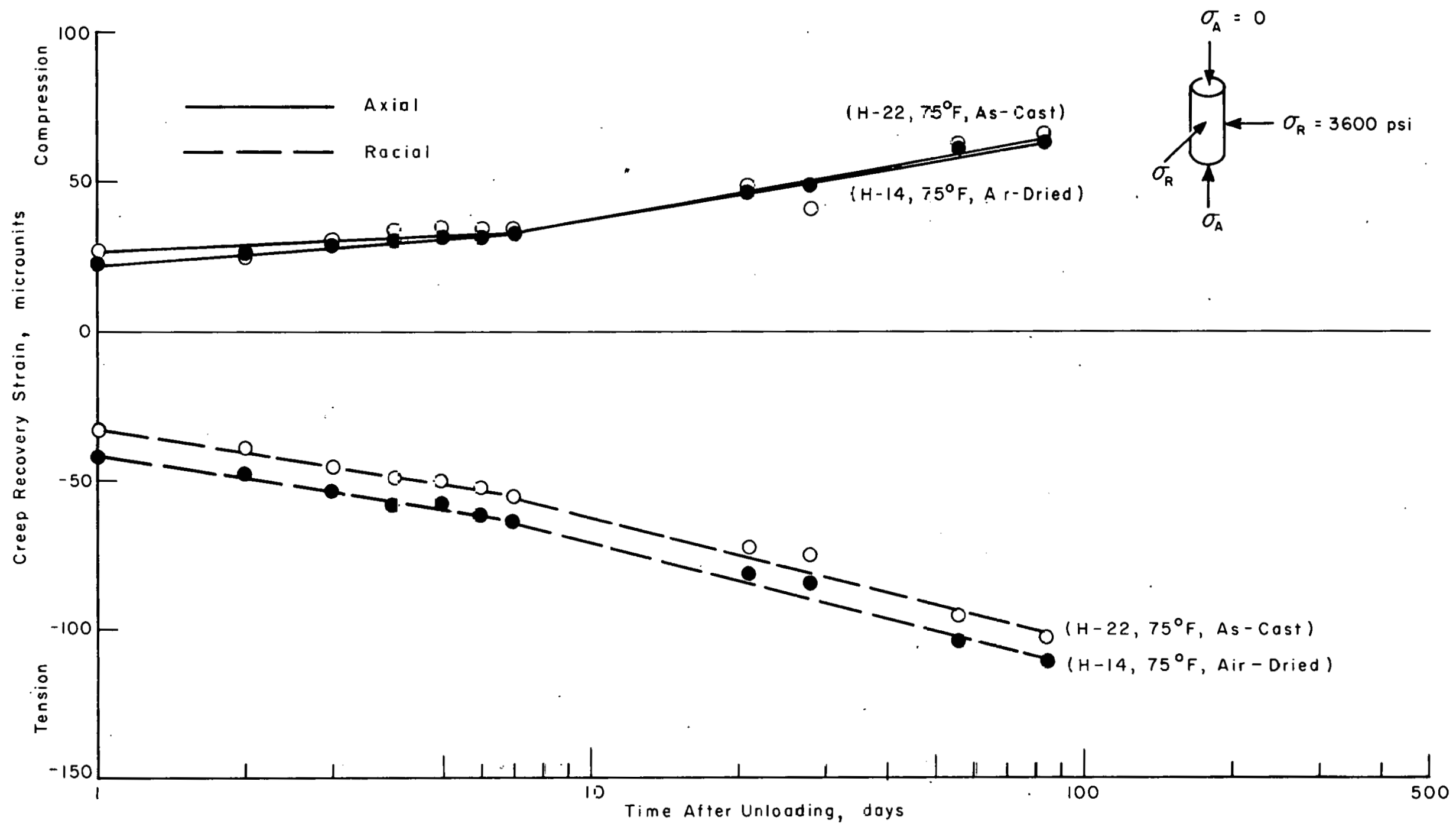

F-g 45. Ef specimens loaded biaxially at 36.00 psi. 


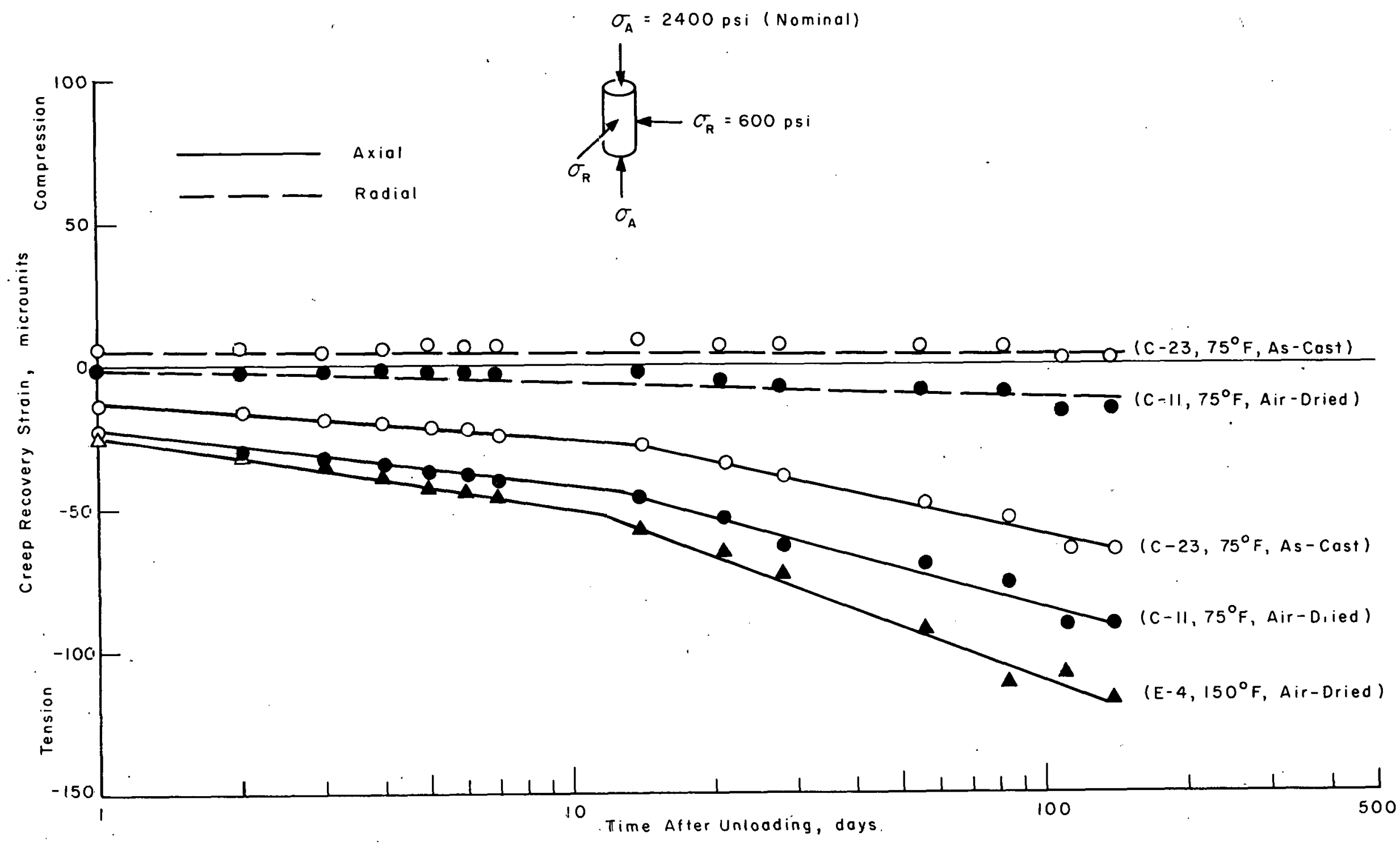

Fig 46. Effect of temperature and curing history on creep recovery for 90-day specimens loaded triaxially; $\sigma_{a}=2400 \mathrm{psi}, \sigma_{\mathrm{r}}=600 \mathrm{psi}$. 


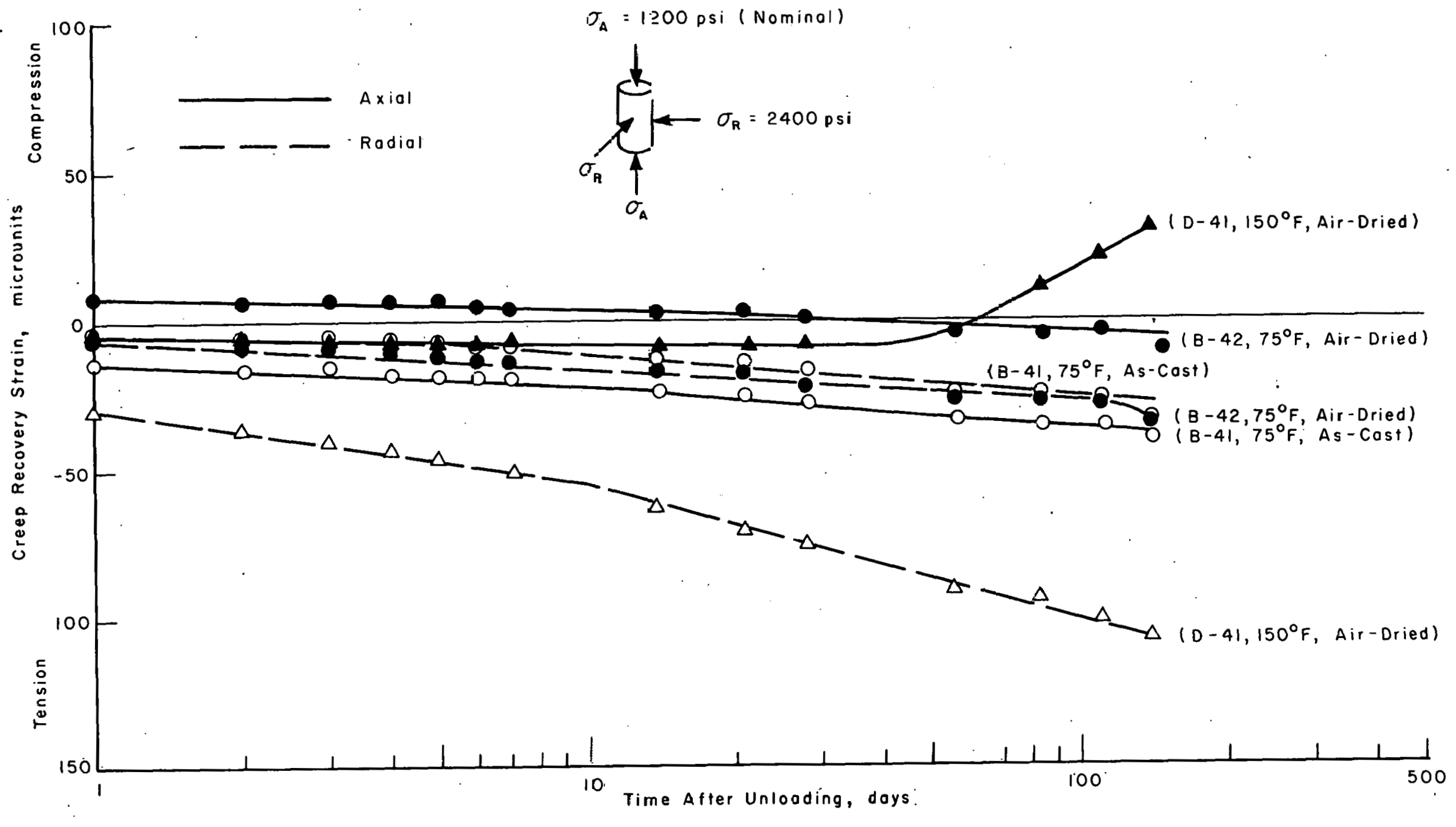

Fig 47. Effect of temperature and curing history. on creep recovery for 90-day specimens loaded triaxially; $\sigma_{a}=1200$ psi, $\sigma_{r}=240 c \cdot p s i$. 


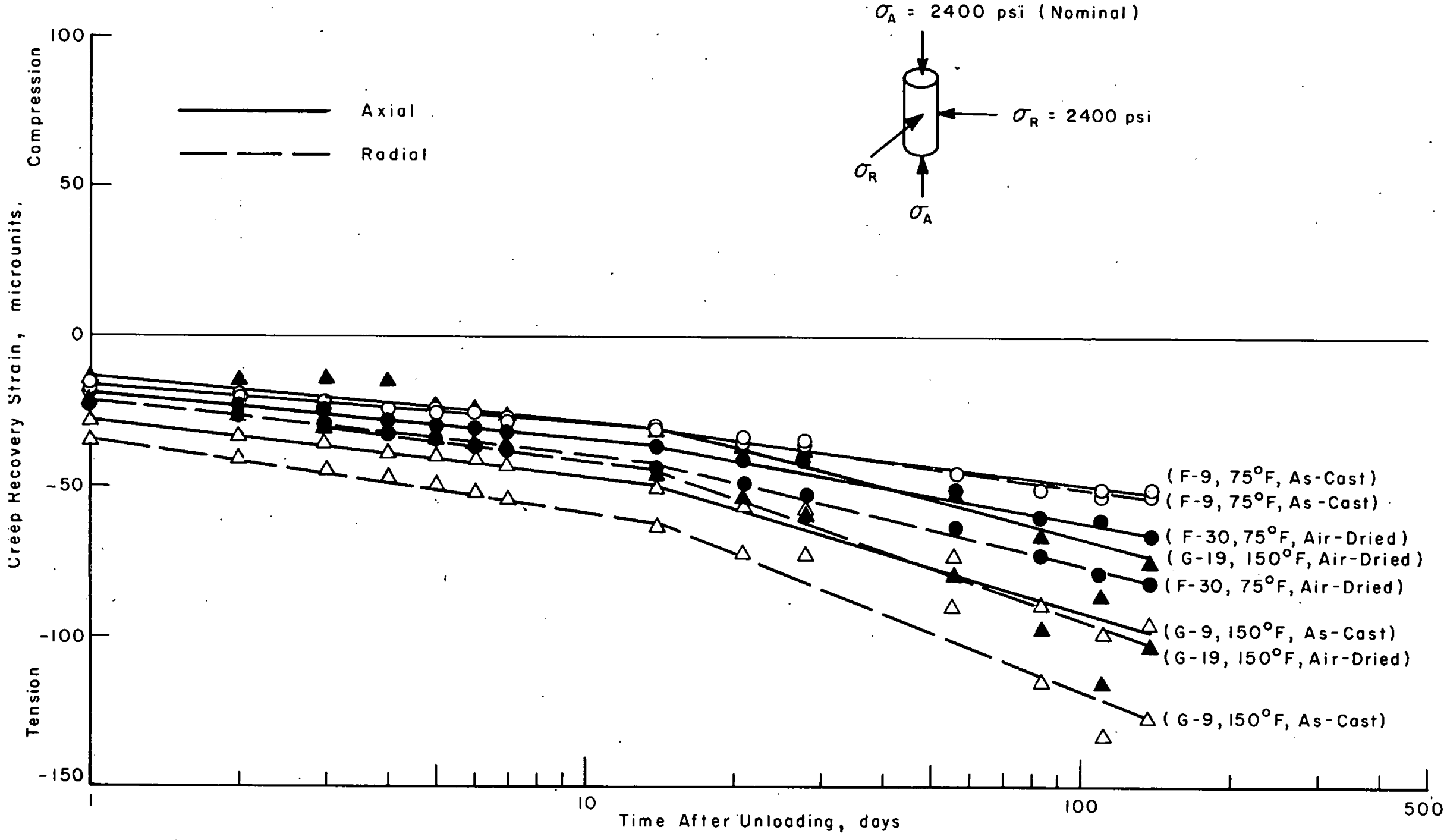

Fig 48. Effect of temperature and curing history on creep recovery for 90-day specimens loade triaxially; $\sigma_{a}=\sigma_{r}=2400$ psi. 


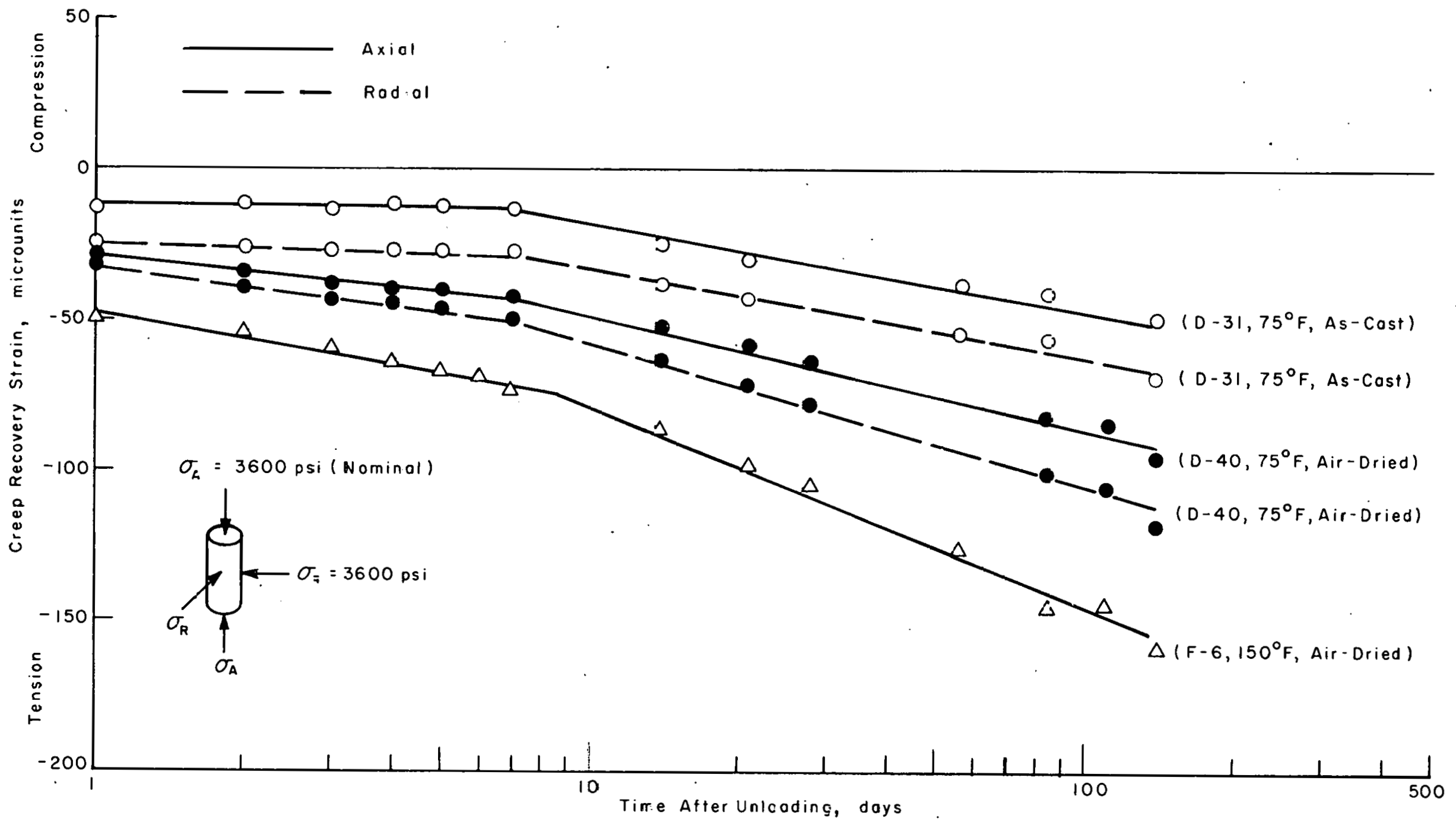

Fig 49. Effect of temperatuze and curing history on creep recovery for 90-day specimens loaded triaxially; $\sigma_{a}=\sigma_{\Xi}=3600$ psi. 
was independent of the temperature at which the test was conducted but that the creep rate increased with increased temperature up to $160^{\circ} \mathrm{F}$. In this investigation, however, a definite temperature effect was evident, as shown in Figs 42 through 49, for different curing histories and different states of stress. For specimens loaded uniaxially at 600 psi (Fig 42), the magnitude of the recovery strains was larger for the specimens at $150^{\circ} \mathrm{F}$ than at $75^{\circ} \mathrm{F}$; however, the differences were of no practical significance. At a higher stress level, 2400 psi, the effect of temperature was more pronounced (Fig 43). For the air-dried specimens, the creep recovery strains were larger at $150^{\circ}$. $F$ than at $75^{\circ} \mathrm{F}$, but the diffcrences were small. The effect of temperature could not be evaluated for the biaxially loaded specimens since most of the gages at $150^{\circ} \mathrm{F}$ had failed prior to unloading. For triaxially loaded specimens (Figs 46 through 49), the creep recovery strains for specimens at $150^{\circ} \mathrm{F}$ were substantially larger than those at $75^{\circ} \mathrm{F}$ for both the as-cast and the air-dried cases. Thus, it was concluded that, in general, the creep recovery strains were larger at $150^{\circ} \mathrm{F}$ than at $75^{\circ} \mathrm{F}$.

Curing History. The air-dried specimens generally showed larger instantaneous recovery strains than the as-cast specimens, although the differences were small unless the stress levels were high. This may possibly be related to the fact that as-cast specimens exhibited higher strengths than air-dried specimens.

The effect of the curing history on the creep recovery strains for different levels of temperature and at different states of stress is also shown in Figs 42 through 49.

Thus, it was concluded that the air-dried specimens exhibited larger creep recovery strains in the direction of the major stress while in the direction perpendicular to the major stress the creep recovery strains were smaller. Again, this may be related to the fact that the as-cast specimens had higher strengths than the air-dried specimens, and the possibility that creep recovery strains are related to the streligth of concrete.

State of Stress. The effect of stress level on the instantaneous recovery was similar to the effect of stress level on creep recovery, regardless of whether the stress condition was uniaxial, biaxial, or triaxial. It was found that instantaneous recovery was definitely a functiun of the magnitude of the stress removed. For the uniaxial and biaxial loading, it was 
concluded that there was a linear relationship between the instantaneous recovery and the magnitude of the removed stress since the relationships passed through the origin.

As reported in Ref 2, previous investigations have shown conflicting results with regard to state of stress. Tn some caeco, it was cuncluded that creep recovery is a function of the previously sustained stress, while other studies found that creep recovery was independent of the magnitude of the removed stress. The results of this experiment indicated that creep recovery was dependent on the magnitude and the state of stress previously appliad. for uniaxially and biaxially loaded specimens, the recovery straine both in the direction and perpendicular to the direction of the removed stress were.larger at the higher 8 tress levels. Th1s indicates that the magnitude of the creep recovery strains was related to the magnitude of the removed stress.

For triaxially loaded specimens, the results indicate that when a large radial stress was removed, the magnitude of the axial creep recovery strain decreased when the axial stresses were large and increased when the axial stresses were relatively small. At the same time, when the removed radial stress increased, the radial creep recovery showed a sharp increase in the tensile directlon. These effects were similar to the effects observed for creep strain.

Curlng and Loading Times. The recovery characteristics for the specimens loaded for 4.75 or 5.25 years followed by a recovery period of 77 days are shown in Table 16. Based on the limited number of specimens available, there was no apparent effect produced by the increased curing and load times.

Relationsh1ps Between Instantaneous Loading, Creep, and Recoveiy

Instantaneous Recovery and Loading Strains for 90-Day Specimens. Fur the uniaxial loading conditions at $75^{\circ} \mathrm{F}$, the ratios of the Instantaneous recovery strain and the instantaneous loading strain of the as-cast specimens (Table 18) averaged 0.976, while for the air-dried specimens the ratios averaged 1.062 . For the biaxially loaded specimens, the ratios averaged 0.966 for the ae-cast specimens, while in the air-dried case the ratios averaged 1.014 . For the triaxially loaded condition the variation between specimens was larger and the ratios averaged 1.041 and 1.021 , respectively, for the as-cast specimens 
TABLE 18. RELATI ONSHI PS BETWEEN INS TANTANEOUS, CREEP, AND RECOVERY CHARACTERIS TICS

\begin{tabular}{|c|c|c|c|c|c|c|c|c|c|c|c|c|c|}
\hline 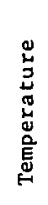 & 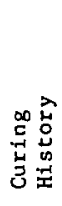 & 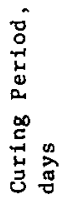 & Specimen & \multicolumn{2}{|c|}{$\begin{array}{c}\text { Stress, } \\
\text { psi }\end{array}$} & \multicolumn{2}{|c|}{$\epsilon_{i r} / \epsilon_{i}$} & \multicolumn{2}{|c|}{$\begin{array}{l}{ }^{B} \mathrm{cr}{ }^{/ 6} \mathrm{c} \\
\text { Axial }\end{array}$} & \multicolumn{2}{|c|}{$\varepsilon_{\mathrm{cr}} / \varepsilon_{\mathrm{ir}}$} & $\begin{array}{l}\text { Instant. } \\
\text { Recovery } \\
\text { Poisson's } \\
\text { Ratio }\end{array}$ & $\begin{array}{l}\text { Creep } \\
\text { Recovery } \\
\text { Poisson 's } \\
\text { Ratio }\end{array}$ \\
\hline \multirow{6}{*}{$\stackrel{c a n}{i n}$} & \multirow[t]{3}{*}{$\begin{array}{l}u \\
0 \\
o \\
\vdots \\
\vdots \\
\vdots\end{array}$} & 용 & $\begin{array}{l}E-39 \\
B-7 \\
F-13 \\
H-22 \\
E-5 \\
C-23 \\
C-16 x \\
D-26 \\
B-41 \\
F-9 \\
G-35 \\
D-31 \\
\end{array}$ & $\begin{array}{r}600 \\
2400 \\
0 \\
0 \\
600 \\
2400 \\
1200 \\
3600 \\
1200 \\
2400 \\
600 \\
3600 \\
\end{array}$ & $\begin{array}{r}0 \\
0 \\
600 \\
3600 \\
600 \\
600 \\
1200 \\
1200 \\
2400 \\
2400 \\
3600 \\
3600 \\
\end{array}$ & $\begin{array}{c}-.98 \\
-1.04 \\
-1.06 \\
-. .91 \\
-1.03 \\
-1.05 \\
- \\
-1.05 \\
22.25 \\
-1.02 \\
-.91 \\
-.96 \\
\end{array}$ & $\begin{array}{l}-.88 \\
-1.00 \\
-1.03 \\
-\quad .87 \\
-. .93 \\
-1.80 \\
- \\
.08 \\
-.08 \\
-1.01 \\
-\quad .92 \\
-\quad .94 \\
\end{array}$ & $\begin{array}{l}-.11 \\
-.21 \\
-.22 \\
-.21 \\
-.67 \\
-.27 \\
-.18 \\
-.24 \\
-.12 \\
-.27 \\
-.23 \\
-.16 \\
\end{array}$ & $\begin{array}{r}.60 \\
-.45 \\
-.37 \\
-.14 \\
-.43 \\
-.13 \\
-.03 \\
-.23 \\
-.21 \\
-.23 \\
-.20 \\
-.20 \\
\end{array}$ & $\begin{array}{l}.09 \\
.17 \\
.15 \\
.22 \\
.41 \\
.22 \\
.23 \\
.18 \\
.22 \\
.28 \\
.18 \\
.18 \\
\end{array}$ & $\begin{array}{r}.26 \\
.20 \\
.28 \\
.19 \\
.30 \\
.11 \\
.16 \\
-6.00 \\
.17 \\
.27 \\
.25 \\
.21 \\
\end{array}$ & $\begin{array}{r}.27 \\
.24 \\
.26 \\
.22 \\
.36 \\
.26 \\
.26 \\
.26 \\
-.70 \\
-.06 \\
.25 \\
.34\end{array}$ & $\begin{array}{r}.75 \\
.28 \\
.16 \\
.24 \\
-1.00 \\
.24 \\
.51 \\
.30 \\
-3.20 \\
-.24 \\
.20 \\
.42\end{array}$ \\
\hline & & $\stackrel{\infty}{\infty}$ & $\begin{array}{l}\mathrm{H}-45 \\
\mathrm{H}-34\end{array}$ & $\begin{array}{r}600 \\
2400\end{array}$ & $\begin{array}{l}0 \\
0\end{array}$ & $\begin{array}{l}-.79 \\
-1.11\end{array}$ & $\begin{array}{l}-1.38 \\
-1.13\end{array}$ & $\begin{array}{r}-1.48 \\
-112.50\end{array}$ & $\begin{array}{r}.00 \\
-.30\end{array}$ & $\begin{array}{l}.11 \\
.10\end{array}$ & $\begin{array}{l}.00 \\
.25\end{array}$ & $\begin{array}{l}.44 \\
.22\end{array}$ & $\begin{array}{l}.00 \\
.53\end{array}$ \\
\hline & & $\hat{n}$ & $\begin{array}{l}\mathrm{H}-5 \\
\mathrm{H}-24\end{array}$ & $\begin{array}{r}600 \\
2400\end{array}$ & $\begin{array}{l}0 \\
0\end{array}$ & $\begin{array}{l}-.99 \\
-1.20\end{array}$ & $\begin{array}{l}-1.05 \\
-1.01\end{array}$ & $\begin{array}{l}-.14 \\
-1.18\end{array}$ & $\begin{array}{l}-.05 \\
-.06\end{array}$ & $\begin{array}{l}.07 \\
.11\end{array}$ & $\begin{array}{l}.19 \\
.09\end{array}$ & $\begin{array}{l}.29 \\
.23\end{array}$ & $\begin{array}{l}.80 \\
.18\end{array}$ \\
\hline & \multirow[t]{3}{*}{ 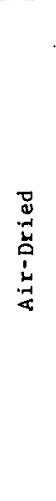 } & ஜू & $\begin{array}{l}\text { E-40 } \\
\text { B-19 } \\
\text { F-42 } \\
\text { H-14 } \\
\text { E-13 } \\
C-11 \\
C-17 \\
D-44 \\
B-42 \\
\text { F-30 } \\
\text { G-30 } \\
\text { D-40 }\end{array}$ & $\begin{array}{r}600 \\
2400 \\
0 \\
0 \\
600 \\
2400 \\
1200 \\
3600 \\
1200 \\
2400 \\
600 \\
3600\end{array}$ & $\begin{array}{r}0 \\
0 \\
600 \\
3600 \\
600 \\
600 \\
1200 \\
1200 \\
2400 \\
2400 \\
3600 \\
3600\end{array}$ & $\begin{array}{c}-1.08 \\
-1.14 \\
-1.02 \\
-. .93 \\
-1.59 \\
-1.16 \\
-. .93 \\
- \\
.38 .25 \\
-1.08 \\
-1.84 \\
-1.00\end{array}$ & $\begin{array}{r}-1.04 \\
-. .99 \\
-1.10 \\
-1.08 \\
-.71 \\
-.94 \\
-.81 \\
-.85 \\
-1.10 \\
-1.07 \\
-1.07\end{array}$ & $\begin{array}{l}-.23 \\
-. .22 \\
-.03 \\
-. .18 \\
-. .36 \\
-.23 \\
-.69 \\
- \\
-.04 \\
-. .25 \\
-.24 \\
-.18\end{array}$ & $\begin{array}{c}.12 \\
-.37 \\
-.28 \\
- \\
-.21 \\
2.00 \\
-.51 \\
-.23 \\
-.26 \\
-.19 \\
- \\
-.17 \\
\end{array}$ & $\begin{array}{l}.16 \\
.20 \\
.02 \\
.20 \\
.31 \\
.24 \\
.34 \\
- \\
.06 \\
.36 \\
.15 \\
.30\end{array}$ & $\begin{array}{r}-.07 \\
.16 \\
.28 \\
- \\
.29 \\
-1.07 \\
.24 \\
2.00 \\
.15 \\
.34 \\
- \\
.31\end{array}$ & $\begin{array}{l}.27 \\
.24 \\
.25 \\
.09 \\
.09 \\
.24 \\
.30 \\
- \\
.24 \\
.24 \\
- \\
.37 \\
\end{array}$ & $\begin{array}{r}-.12 \\
.18 \\
.02 \\
.21 \\
-1.00 \\
.09 \\
- \\
.12 \\
.10 \\
.17 \\
.18 \\
.38 \\
\end{array}$ \\
\hline & & $\stackrel{\infty}{\varrho}$ & $\begin{array}{l}I-39 \\
I-20\end{array}$ & $\begin{array}{r}600 \\
2400\end{array}$ & $\begin{array}{l}0 \\
0\end{array}$ & $\begin{array}{r}-.97 \\
-1.08\end{array}$ & $\begin{array}{l}-.91 \\
-1.05\end{array}$ & $\begin{array}{l}-.41 \\
-2.61\end{array}$ & $\begin{array}{l}-.57 \\
-.15\end{array}$ & $\begin{array}{l}.08 \\
.13\end{array}$ & $\begin{array}{l}.48 \\
.14\end{array}$ & $\begin{array}{l}.28 \\
.24\end{array}$ & $\begin{array}{r}1.67 \\
.26\end{array}$ \\
\hline & & $\tilde{n}$ & $\begin{array}{l}\mathrm{H}-31 \\
\mathrm{H}-17\end{array}$ & $\begin{array}{r}600 \\
2400\end{array}$ & $\begin{array}{l}0 \\
0\end{array}$ & $\begin{array}{l}-1.08 \\
-1.08\end{array}$ & $\begin{array}{l}-.85 \\
-1.34\end{array}$ & $\begin{array}{l}=.03 \\
-.46\end{array}$ & $\begin{array}{l}-.58 \\
-.24\end{array}$ & $\begin{array}{l}.02 \\
.10\end{array}$ & $\begin{array}{l}.41 \\
.17\end{array}$ & $\begin{array}{l}.16 \\
.24\end{array}$ & $\begin{array}{r}3.50 \\
.38\end{array}$ \\
\hline \multirow[b]{2}{*}{$\begin{array}{l}0 \\
0 \\
0 \\
0\end{array}$} & 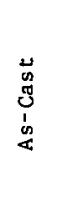 & 8 & $\begin{array}{l}\text { B-4 } \\
\text { D- } 15 \\
\text { F-33 } \\
\text { A-35 } \\
\text { C- } 12 \\
\text { D-2x } \\
\text { G-9 }\end{array}$ & $\begin{array}{r}600 \\
1200 \\
2400 \\
0 \\
1200 \\
1200 \\
2400\end{array}$ & $\begin{array}{r}0 \\
0 \\
0 \\
600 \\
1200 \\
2400 \\
2400\end{array}$ & $\begin{array}{c}- \\
-1.04 \\
- \\
-1.86 \\
- \\
-1.10\end{array}$ & $\begin{array}{c}-1.00 \\
\vdots \\
- \\
-.92 \\
\vdots \\
-1.14\end{array}$ & $\begin{array}{l}- \\
-.37 \\
- \\
- \\
-.29 \\
-.16 \\
-.35\end{array}$ & $\begin{array}{l}-.10 \\
- \\
- \\
-.49 \\
- \\
- \\
-.36\end{array}$ & $\begin{array}{l}- \\
.34 \\
- \\
- \\
.29 \\
.30 \\
.48\end{array}$ & $\begin{array}{c}.36 \\
- \\
.52 \\
- \\
-.26 \\
.47\end{array}$ & $\begin{array}{l}- \\
- \\
- \\
- \\
- \\
.26 \\
.37\end{array}$ & $\begin{array}{c}- \\
- \\
- \\
- \\
-.21 \\
.36\end{array}$ \\
\hline & 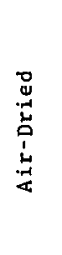 & ㅇ & $\begin{array}{l}\text { B-1 } \\
\text { D-22 } \\
\text { F-34 } \\
D-3 \\
\text { E-4 } \\
\text { C-46x } \\
\text { D- } 41 \\
\text { G-19 } \\
\text { F- } 6\end{array}$ & $\begin{array}{r}600 \\
1200 \\
2400 \\
0 \\
2400 \\
1200 \\
1200 \\
2400 \\
3600\end{array}$ & $\begin{array}{r}0 \\
0 \\
0 \\
600 \\
600 \\
1200 \\
2400 \\
2400 \\
3600\end{array}$ & $\begin{array}{r}-.94 \\
-.92 \\
-.92 \\
-1.15 \\
-.91 \\
- \\
-.13 \\
-.99 \\
-.976\end{array}$ & $\begin{array}{c}-.84 \\
-.87 \\
- \\
- \\
- \\
- \\
-.96 \\
-.98 \\
-\end{array}$ & $\begin{array}{l}-.17 \\
-.26 \\
=.18 \\
- \\
-.28 \\
-.24 \\
-. .24 \\
-.25 \\
-. .23\end{array}$ & $\begin{array}{l}- \\
4.00 \\
- \\
- \\
- \\
-.06 \\
-.21 \\
-.27 \\
-.\end{array}$ & $\begin{array}{r}.20 \\
.23 \\
.26 \\
. \\
.34 \\
.31 \\
10.33 \\
.40 \\
.54\end{array}$ & $\begin{array}{l}.86 \\
.17 \\
- \\
- \\
- \\
.26 \\
.29 \\
.42 \\
-\end{array}$ & $\begin{array}{l}.22 \\
.20 \\
- \\
- \\
- \\
.23 \\
.23 \\
.36 \\
-\end{array}$ & $\begin{array}{l}.95 \\
.15 \\
- \\
- \\
- \\
.16 \\
.31 \\
.38 \\
-\end{array}$ \\
\hline
\end{tabular}

* Nominal axial stress.

$x$ Radial pressure reduced to zero due to oll leak. 
and air-dried specimens. The values for the triaxial loading conditions were evaluated excluding the ratios of specimens $B-41$ and $B-42$ in the axial direction, which were obviously in error.

The overall average ratio of the instantaneous recovery to the instantaneous loading strain for all the different loading conditions at $75^{\circ} \mathrm{F}$ was 1.020. Thus, the instantaneous recovery at the time of unloading generally was larger than the instantaneous strain at the time of loading.

Very few gages in the 90 -day as-cast sperimens at $150^{\circ} \mathrm{F}$ lasted through the entire test period. Thus, a detailed evaluation of the creep recovery behavior of the as-cast specimens could not be made. Nevertheless, the instantaneous recovery strains generally were larger than the instantaneous loading strains for the as-cast specimens, with an average ratio of 1.175 , but lower than the instantaneous loading, strain for the air-dried specimens, with an average ratio of 0.922 .

Creep Recovery and Creep Strains for 90-Day Specimens." The creep strain recovered after a period of five months from the time of unloading for specimens at $75^{\circ} \mathrm{F}$ varied from 3 to 69 percent of the creep strain developed during one year of loading. The ratio of creep recovery strain after five months to creep strain after one year did not show any systematic difference for different states of stress. This ratio varied from 0.034 to 0.667 and averaged 0.241 for the as-cast specimens, while it varied from 0.030 to 0.686 and averaged 0.256 for the air-dried specimens; thus, the air-dried specimens generally exhibited a larger recovery after five months, relative to the r.rep. strain developed after one year, than did the as-cast specimens.

At $150^{\circ} \mathrm{F}$, the creep recovery strains varied from 6 to 49 percent of the creep strain developed after one year under load. For the as-cast specimens, the ratio of the creep recovery strain after five months to the creep strain after one year varied from 0.100 to 0.486 and averaged 0.301 , while for the air-dried specimens it varied from 0.062 to 0.284 and averaged 0.216 . Unlike specimens at $75^{\circ} \mathrm{F}$, the average values shown here indicate that the as-cast specimens recovered a larger percentage of the creep strain developed after one year than did the air-dried specimens.

Creep Recovery and Instantaneous Recovery Strains for 90-Day Specimens. At $75^{\circ} \mathrm{F}$, the creep recovery strains after a period of five months were small in comparison to the instantaneous elastic recovery, in contrast to the creep 
strain, which in some cases exceeded the magnitude of the instantaneous elastic strain. The ratio of the creep recovery after five months over the instantaneous elastic recovery varied from 0.094 to 0.410 and averaged 0.218 for as-cast specimens, while it varied from 0.019 to 0.364 and averaged 0.230 for the air-dried specimens.

For specimens at $150^{\circ} \mathrm{F}$, the creep recovery strain after a period of five months was also small in comparison to the instantaneous elastic recovery; however, the ratios were larger than at $75^{\circ} \mathrm{F}$. The ratio of the creep recovery after five months to the. instantaneous elastic recovery for the ascast specimens varied from 0.294 to 0.523 and averaged 0.396 , while for the air-dried specimens the ratios varied from 0.170 to 0.857 and averaged 0.357 . In contrast to specimens at $75^{\circ} \mathrm{F}$, the $150^{\circ} \mathrm{F}$ as-cast specimens showed a higher average ratio of creep recovery strain over the instantaneous recovery strain than the corresponding air-dried specimens.

Recovery Poisson's Ratio for 90-Day Specimens

Instantaneous Recovery. The air-dried specimens exhibited a smaller average Poisson's ratio than the as-cast specimens. Excluding the hydrostatically loaded specimens, the instantaneous recovery Poisson's ratios for all specimens at $75^{\circ} \mathrm{F}$ ranged from 0.22 to 0.27 and averaged 0.25 for both the as-cast and the air-dried specimens, respectively. At $150^{\circ} \mathrm{F}$, this property could be evaluated for only one as-cast specimen and three air-dried specimens. For the as-cast specimens, the elastic recovery Poisson's ratio was 0.26 , which was essentially equal to that of the as-cast specimens at $75^{\circ} \mathrm{F}$ and was even closer to the average values of the elastic Poisson's ratio for the as-cast specimens at both $75^{\circ} \mathrm{F}$ and $150^{\circ} \mathrm{F}$. For the air-dried specimens, the average instantaneous recovery Poisson's ratio was 0.22 . This value was lower than the instantaneous recovery Poisson's ratio of the air-dried specimens at $75^{\circ} \mathrm{F}$ and was also smaller than the elastic Poisson's ratio of the air-dried specimens at the time of loading at both temperatures. It was concluded that the instantaneous recovery Poisson's ratio was not affected by temperature or state of stress but was affected by curing history, and they were essentially equal to the values of the elastic Poisson's ratios at the time of loading.

Creep Recovery. A Poisson's effect was aleo noticed in the creep recovery period. The creep recovery Poisson's ratio for each specimen under the $75^{\circ} \mathrm{F}$ 
.. environment was calculated and recorded in Table 17. Excluding the hydrostatically loaded specimens and specimens penetrated by oil, the creep recovery Poisson's ratio five months after unloading varied from 0.16 to 0.28 and averaged 0.23 for as-cast specimens, while it varied from 0.02 to 0.21 and averaged 0.13 for the air-dried specimens. Similar to previous Poisson's ratios calculated at different stages of the test, the average creep recovery Poisson's ratio of the air-dried specimens was smaller than that of the ascast specimens.

It was not possible to make any valid judgment ot the sroep rocovery Poisson.'s ratio of sperimens at $150^{\circ}$ F lue to the large percentage of gage failures. Excluding hydrostatically loaded specimens (Chapter 4) and specimens penetrated by oil, the two creep recovery Poisson's ratios were 0.15 and 0.31 , both for air-dried specimens.

Recovery'Poisson's Ratio for 183 and 365-Day Specimens

A definite Poisson's effect was observed for both instantaneous recovery and creep recovery of the specimens which were subjected to load for periods of 5.25 or 4.75 years followed by a 77-day recovery period.

With the possible exception of the specimens subjected to a uniaxial stress of $600 \mathrm{psi}$, the instantaneous recovery and creep recovery were con3istent with values reported for the 90-day specimens. Thus, there was no apparent time effect. 'In addition, there was no apparent effect of curing history. However, the number of specimens was sma11.

\section{Est1mation of Recovery Strains by Superposition}

As discussed in Ref 2 , many researchers have inveetigated and discussed the validity and accuracy of the principle of superposition, and most of them concluded that il uverestimates the measured creep recovery strains. Figurco 50 and 51 compare estimated with measured creep recovery strains for specimens which were cured for 90 days, loaded for one year, and then unloaded. The estimated creep recovery strains were obtained for the specimens which were 1naded at an age of 365 days by applying the principle of superposition of strain. These two figures clearly indicate that the estimated values were substantially larger than the measured creep strains and indicate that superposition overestimates creep recovery strains. Even though there was a 'difference of $90^{\prime}$ days between the time that specimens $\mathrm{H}-5$ and $\mathrm{H}-24$ were loaded, 


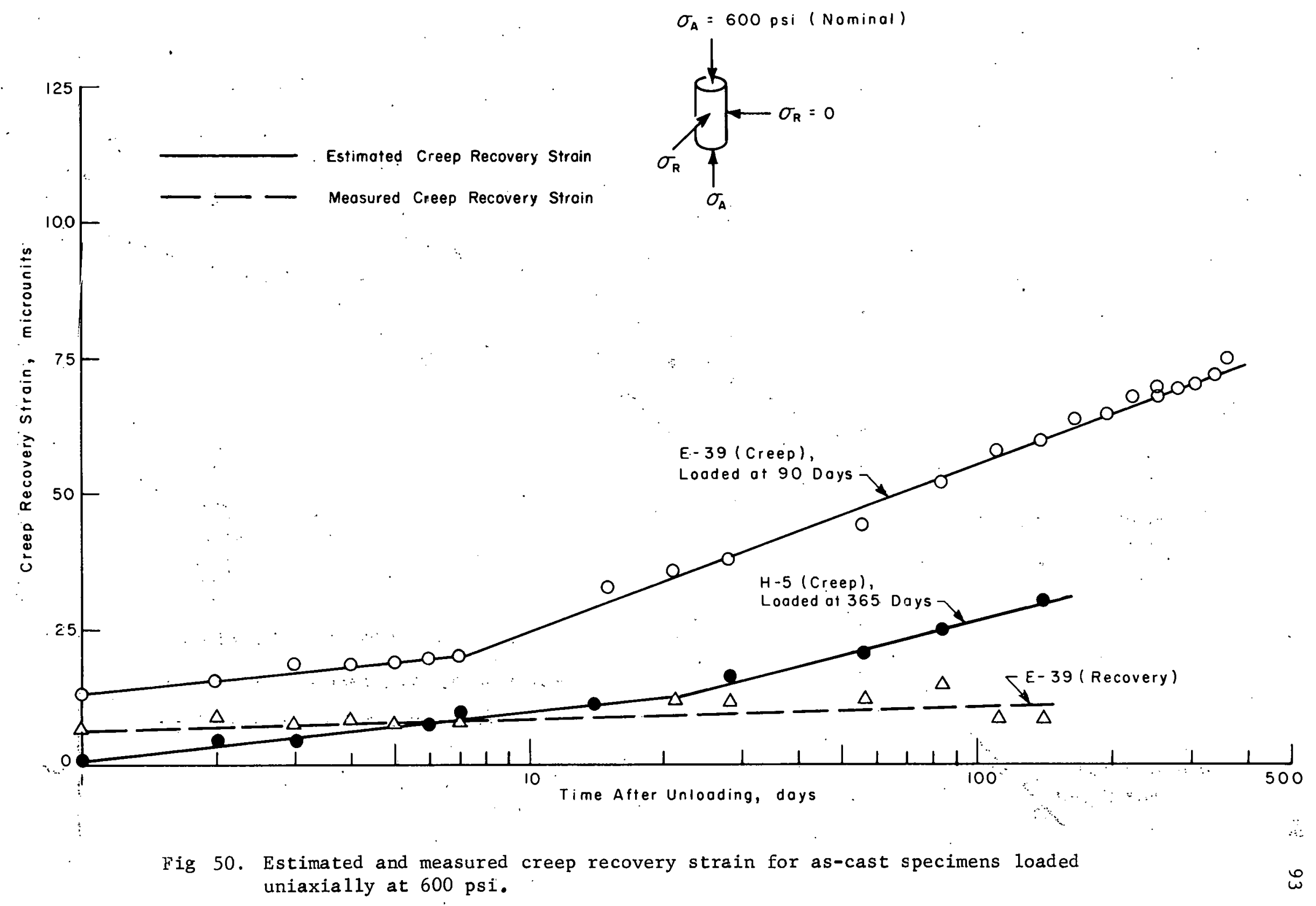




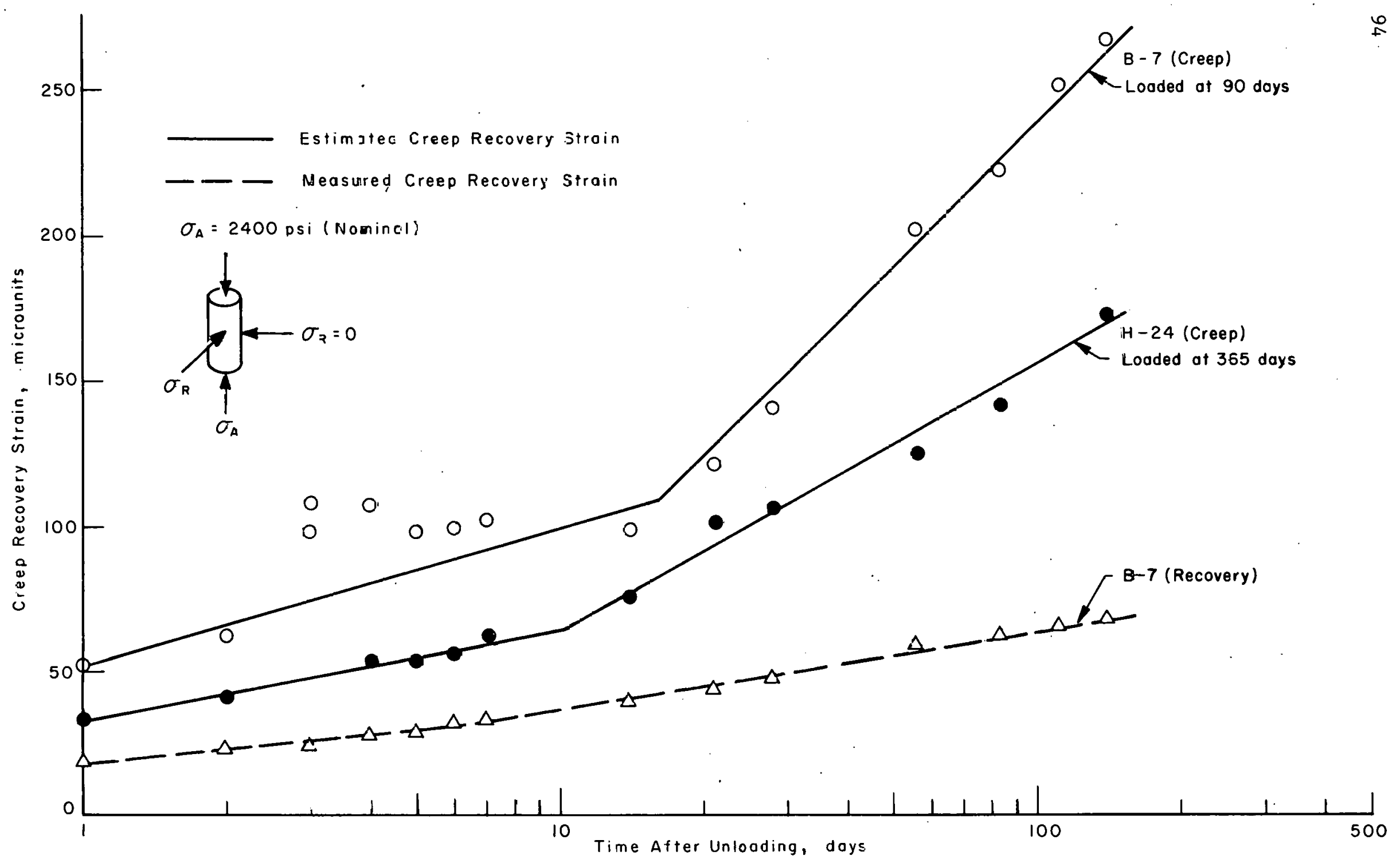

Fig 51. Estimated and measured creep recovery strain for as-cast specimens loadel uniaxially at 2400 psi. 
365 days after casting, and the time that specimens E-39 and B-7 were unloaded, 454 days after casting, it is felt that the difference between the estimated and measured creep recovery strains was so large that the 90-day difference in age would not have any significant effect. Therefore, it is concluded that the use of superposition of creep strains as a means of estimating recovery is not accurate. 


\section{THIS PAGE}

\section{WAS INTENTIONALLY \\ LEFT BLANK}


CHAPTER 4. EVALUATION OF TEST PROGRAM

The majority of the equipment, procedures, and techniques employed were developed specifically for this project with only limited opportunity for evaluation prior to their actual use. This chapter deals with the equipment, instrumentation, and procedures in the study together with a post-test evaluation of the specimens. For the most part, the equipment and procedures utilized were satisfactory.

As each phase of this study was completed, the specimens involved were subjected to a careful and detailed evaluatiun. Each specimen was weighed, physically disassembled, inspected externally and internally, and photographed in order to identify those specimens which may have provided questionable data during the course of this study. Pertinent information resulting from this evaluation is presented in Tables $9,19,20$, and 21 .

\section{EQUIPMENT AND INSTRUMENTATION}

\section{Loading Unit}

The loading frame was designed and fabricated specifically. for this project. A schematic of the loading unit for the triaxially loaded case (Fig 4, $p$ 16) illustrates all components of the loading systems. The radial load was applied directly to the sealed specimen by hydraulic pressure through oil contained by a steel pressure jacket; the axial load was applied by a hydraulic ram. Thus, the triaxial loading system was made up of both an axial and a radial pressure system, which permitted each pressure to be vairied independently. The axial loading frame without the pressure jackets was used for the uniaxial case. "The radial pressure jacket without the axial loading frame was used for the biaxial case.

The loading system was satisfactory; however, preliminary tests revealed the following two potential problem sources:

(1) reduced axial load due to friction and

(2) penetration of oil from radial pressure system. 
TABLE 19. SUMHARY OF POS T- -EST EVALUATION AND GAGE PERFORMA.VE OF UNIAXIALLY-LOADED CREEP SPECIMENS

\begin{tabular}{|c|c|c|c|c|c|c|c|c|c|c|}
\hline$\underset{\mathrm{F}}{\text { Temperature, }}$ & $\begin{array}{l}\text { Curing } \\
\text { History }\end{array}$ & $\begin{array}{l}\text { Curirg } \\
\text { Periad, } \\
\text { days }\end{array}$ & S secimen & $\begin{array}{c}\text { Axiall } \\
\text { stress } \\
\text { psi }\end{array}$ & $\begin{array}{l}\text { Weig } \\
\text { Curing } \\
\text { Period }\end{array}$ & $\begin{array}{l}\text { thange } \\
\text { Test } \\
\text { Period }\end{array}$ & $\begin{array}{l}\text { oz } \\
\text { Tota } 1\end{array}$ & $\begin{array}{c}\text { Gage } \\
\text { Days Aft } \\
\text { Axial }\end{array}$ & $\begin{array}{l}\text { ailed, } \\
\text { r Loeçing } \\
\text { Ra.j: }=1\end{array}$ & Remarks \\
\hline \multirow{6}{*}{75} & \multirow{3}{*}{ As-Cast } & 90. & $\begin{array}{l}\text { E- } 39 \\
\text { B- } 7\end{array}$ & $\begin{array}{r}600 \\
2400 \\
\end{array}$ & $\begin{array}{l}-\Xi .0 \\
-\quad 2.0 \\
\end{array}$ & $\begin{array}{r}-1.2 \\
0.0 \\
\end{array}$ & $\begin{array}{l}-4.2 \\
-2.0 \\
\end{array}$ & - & - & \\
\hline & & 182 & $\begin{array}{l}\mathrm{H}-45 \\
\mathrm{H}-34\end{array}$ & $\begin{array}{r}600 \\
24 \mathrm{Ca} \\
\end{array}$ & $\begin{array}{l}=* \\
0.0\end{array}$ & $\begin{array}{r}* * \\
-\quad 0.8 \\
\end{array}$ & $\begin{array}{r}-1.2 \\
-0.8 \\
\end{array}$ & - & - & \\
\hline & & 365 & $\begin{array}{l}\text { H- } 5 \\
\text { H- } 24\end{array}$ & $\begin{array}{r}600 \\
240 C\end{array}$ & $\begin{array}{r}3.0 \\
-\quad 1.5\end{array}$ & $\begin{array}{l}-0.5 \\
-2.3\end{array}$ & $\begin{array}{l}-0.5 \\
-3.8\end{array}$ & - & - & \\
\hline & \multirow{3}{*}{ Air-Dri $\equiv d$} & Sil) & $\begin{array}{l}E-40 \\
B-19\end{array}$ & $\begin{array}{r}6100 \\
2400\end{array}$ & $\begin{array}{l}-12.0 \\
-111.0\end{array}$ & $\begin{array}{c}\text { * } \\
-1.5\end{array}$ & $\begin{array}{c}k * \\
-12.5\end{array}$ & - & - & \\
\hline & & 183 & $\begin{array}{c}\mathrm{H}-16) \\
\mathrm{I}-39 \\
\mathrm{I}-20 \\
\end{array}$ & $\begin{array}{r}6010 \\
603 \\
2400 \\
\end{array}$ & $\begin{array}{r}* * \\
-\equiv 1.0 \\
-\quad 6.0 \\
\end{array}$ & $\begin{array}{r}\star \star \\
-1.2 \\
-\quad 2.0 \\
\end{array}$ & $\begin{array}{r}* * \\
-12.2 \\
-\quad 8.0 \\
\end{array}$ & $\begin{array}{l}\mathrm{NA} \\
- \\
- \\
\end{array}$ & $\begin{array}{l}\mathrm{MB} \\
- \\
-\end{array}$ & Damaged, replaced by $\mathrm{I}-39$ \\
\hline & & $3 E 5$ & $\begin{array}{l}\mathrm{H}-31 \\
\mathrm{H}-17\end{array}$ & $\begin{array}{r}\epsilon \infty 00 \\
2<C 0\end{array}$ & $\begin{array}{l}-14.8 \\
-16.0\end{array}$ & $\begin{array}{l}-0.5 \\
-6.2\end{array}$ & $\begin{array}{l}-15.3 \\
-22.2\end{array}$ & - & - & \\
\hline \multirow{2}{*}{150} & As-Cast & 30 & $\begin{array}{l}\text { B-4 } \\
D-15 \\
\text { F- 33 } \\
\text { B- } 16\end{array}$ & $\begin{array}{l}600 \\
1200 \\
2 \div 00 \\
36] C\end{array}$ & $\begin{array}{c}-1.0 \\
-0.5 \\
\star \star \\
-1.0\end{array}$ & $\begin{array}{c}-16.0 \\
-4.0 \\
\star \star \\
-15.0\end{array}$ & $\begin{array}{r}-17.0 \\
-4.5 \\
\star * \\
-16.0\end{array}$ & $\begin{array}{c}308 \\
- \\
- \\
112\end{array}$ & $\begin{array}{c}- \\
2 \approx 4 \\
L \leq 0 \\
-\end{array}$ & Functioned after unload \\
\hline & Air-Dr:ed & 90 & $\begin{array}{l}\text { B-1 } \\
\text { D-22 } \\
\text { F-34 } \\
\text { B-5 }\end{array}$ & $\begin{array}{r}600 \\
1200 \\
240 J \\
360 J\end{array}$ & $\begin{array}{r}-11.5 \\
-9.5 \\
-10.8 \\
-14.5\end{array}$ & $\begin{array}{l}-3.0 \\
-3.0 \\
+1.0 \\
-5.0\end{array}$ & $\begin{array}{r}-14.5 \\
-12.5 \\
-\quad 0.8 \\
-19.5\end{array}$ & $\begin{array}{l}- \\
- \\
- \\
0.5 *\end{array}$ & $\begin{array}{c}- \\
- \\
168 \\
16: 3 *\end{array}$ & \\
\hline
\end{tabular}

$*$ Range of gage exceeded

* Infozmation not obtained

$\mathrm{NA}=\mathrm{N} \cdot \mathrm{ot}$ afplicable 
TABLE 20. SUMMARY DF POS T-TEST EVALUATION AND GAGE PERFORMANCE FOR BIAXIALLY LOADED CREEP SPECIMENS CURED FOR 90 DAYS

\begin{tabular}{|c|c|c|c|c|c|c|c|c|c|c|c|}
\hline $\begin{array}{l}\ddots \\
\text { Temperature, } \\
{ }^{\mathbf{F}} \text {. }\end{array}$ & $\begin{array}{l}\text { Curing } \\
\text { History }\end{array}$ & Specimen & $\begin{array}{c}\text { Radial } \\
\text { Stress, } \\
\text { psi }\end{array}$ & $\begin{array}{l}\text { Weight } \\
\text { Curing } \\
\text { Period }\end{array}$ & $\begin{array}{l}\text { t Change } \\
\text { Test } \\
\text { Period }\end{array}$ & $\begin{array}{l}\text { oz } \\
\text { Tota } 1\end{array}$ & $\begin{array}{l}\text { Presence } \\
\text { Specimen }\end{array}$ & f $0 i 1$ & $\begin{array}{c}\text { Gage } \\
\text { Days Aft } \\
\text { Axia } 1\end{array}$ & $\begin{array}{l}\text { ailed, } \\
\text { r Loading } \\
\text { Radial }\end{array}$ & Remarks \\
\hline \multirow{2}{*}{75} & As-Cast & $\begin{array}{r}F-13 \\
(A-9) \\
H-22\end{array}$ & $\begin{array}{r}600 \\
3600 \\
3600\end{array}$ & $\begin{array}{c}-4.0 \\
-13.0 \\
* *\end{array}$ & $\begin{array}{l}* t \\
* * \\
* x\end{array}$ & 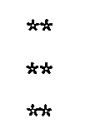 & $\begin{array}{l}- \\
\mathrm{NA} \\
* \star\end{array}$ & $\begin{array}{l}- \\
\mathrm{NA} \\
* *\end{array}$ & $\begin{array}{c}- \\
\text { NA } \\
-\end{array}$ & $\begin{array}{c}- \\
\text { NA } \\
-\end{array}$ & Falled during loading, replaced by $\mathrm{H}-22$ \\
\hline & Air-Dried & $\begin{array}{c}F-42 \\
(A-12) \\
H-14\end{array}$ & $\begin{array}{r}600 \\
3600 \\
3600\end{array}$ & $\begin{array}{l}-10.0 \\
-1=.0 \\
-8.0\end{array}$ & $\begin{array}{l}0.0 \\
\pm x \\
*=\end{array}$ & $\begin{array}{c}-10.0 \\
x+1 \\
x+\infty\end{array}$ & $\begin{array}{l}- \\
\mathrm{NA} \\
* *\end{array}$ & $\begin{array}{l}- \\
\text { NA } \\
* *\end{array}$ & $\begin{array}{l}- \\
\text { NA } \\
-\end{array}$ & $\begin{array}{l}- \\
\mathrm{NA} \\
56 *\end{array}$ & Failed 12 hours after loading, replaced by $\mathrm{H}-14$ \\
\hline \multirow{2}{*}{150} & As-Cast & $\begin{array}{c}A-35 \\
(D-46) \\
I-27 \\
E-43 \\
(C-34) \\
I-16\end{array}$ & $\begin{array}{r}600 \\
1200 \\
1200 \\
2400 \\
3600 \\
3600\end{array}$ & $\begin{array}{r}-2.0 \\
-3.5 \\
* \star \\
-3.0 \\
-2.5 \\
* *\end{array}$ & $\begin{array}{c}* \\
* * \\
* * \\
+1.0 \\
* \star \\
* *\end{array}$ & $\begin{array}{l}* t \\
* * \\
* * \\
-2.0 \\
* * \\
* *\end{array}$ & $\begin{array}{c}- \\
\text { NA } \\
* * \\
- \\
\text { NA } \\
* *\end{array}$ & $\begin{array}{c}\text { yes } \\
\text { NA } \\
* * \\
- \\
\text { NA } \\
* *\end{array}$ & $\begin{array}{l}252 \\
\text { NA } \\
168 \\
56 * \\
\text { NA } \\
56 *\end{array}$ & $\begin{array}{c}-{ }^{-} \\
\mathrm{NA} \\
168 \\
- \\
\mathrm{NA} \\
21 *\end{array}$ & $\begin{array}{l}\text { Failed during loading, replaced by } I-27 \\
\text { Unloaded at } 196 \text { days } \\
\text { Failed during loading, replaced by I- } 16\end{array}$ \\
\hline & Air-Dried & $\begin{array}{l}(A-19) \\
I-13 \\
D-3 \\
E-1 \\
C-13\end{array}$ & $\begin{array}{r}600 \\
600 \\
1200 \\
2400 \\
3600\end{array}$ & $\begin{array}{l}-10.5 \\
-8.0 \\
-11.0 \\
-9.5 \\
-8.5\end{array}$ & 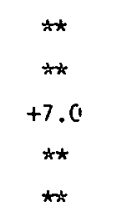 & $\begin{array}{l}* * \\
* * \\
-4.0 \\
* * \\
* *\end{array}$ & $\begin{array}{c}\text { NA } \\
\text { NA } \\
\text { yes } \\
- \\
\text { NA }\end{array}$ & $\begin{array}{c}\text { NA } \\
\text { NA } \\
\text { yes } \\
- \\
\text { NA }\end{array}$ & $\begin{array}{l}\mathrm{NA} \\
\mathrm{Nh} \\
385 \\
21 * \\
\mathrm{NA}\end{array}$ & $\begin{array}{l}\text { NA } \\
\text { NA } \\
224 \\
112 \text { * } \\
\text { NA }\end{array}$ & $\begin{array}{l}\text { Failed during loading, replaced by } \mathrm{I}-13 \\
\text { Failed } 9 \text { hours after loading, not replaced } \\
\text { Fa-led during loading, not replaced }\end{array}$ \\
\hline
\end{tabular}

*Range of gage exceeded

**Information not obtainec.

$\mathrm{NA}=$ Mo: applicable 
TABLE 21. SUMMARY CF FOST-TES T EVALUATION AND GAGE PERFORMANCE FOR TRIAXIALLY LOADEJ CREEP SPECIMENS CURED FOR 90 DAYS

\begin{tabular}{|c|c|c|c|c|c|c|c|c|c|c|c|c|}
\hline$\underset{\mathrm{F}}{\text { Temperature, }}$ & $\begin{array}{l}\text { Cusing } \\
\text { History }\end{array}$ & Specimen & $\begin{array}{c}\text { Axial } \\
\text { stress, } \\
\text { psi }\end{array}$ & $\begin{array}{c}\text { Zacial } \\
\text { Stress, } \\
\text { psi }\end{array}$ & $\begin{array}{l}\text { Wèigh } \\
\text { Curing } \\
\text { Period }\end{array}$ & $\begin{array}{l}\text { Change, } \\
\text { Test } \\
\text { Perioj }\end{array}$ & Total & $\begin{array}{l}\text { Presence } \\
\text { Specimen }\end{array}$ & $\begin{array}{l}\text { oil } \\
\text { Gages }\end{array}$ & $\begin{array}{l}\text { Gage } F \\
\text { Days Afte } \\
\text { Axial }\end{array}$ & $\begin{array}{l}\text { ailed, } \\
\text { R Loading } \\
\text { Radial }\end{array}$ & Renarks \\
\hline \multirow{16}{*}{75} & \multirow{8}{*}{ As-Cast } & E-5 & 600 & 50 & -1.0 & -2.5 & -3.5 & - & - & - & - & \multirow{8}{*}{ Radial pressure reduced to zero-oil leak } \\
\hline & & G-35 & 600 & 3500 & -0.5 & -2.5 & -3.0 & - & - & - & - & \\
\hline & & $c-16$ & 1200 & $1200(c)$ & -1.0 & 0.0 & -1.0 & yes & - & - & - & \\
\hline & & B-41 & 1200 & $2<00$ & -3.5 & +0.5 & -3.0 & - & - & - & - & \\
\hline & & $\mathrm{C}-23^{\circ}$ & 2400 & 600 & -3.0 & +4.0 & +1.0 & yes & - & - & - & \\
\hline & & F-9 & 2400 & 2400 & -4.0 & * & $\star$ & - & - & - & - & \\
\hline & & $D-26$ & 3600 & $: 200$ & -2.0 & +3.8 & +1.8 & yes & yes & - & - & \\
\hline & & $D-31$ & 3600 & 3500 & -3.0 & +3.8 & $+C .8$ & yes & - & - . & $\therefore$ & \\
\hline & \multirow{8}{*}{ Alr-Dried } & E-13 & 600 & 600 & -10.0 & $+*$ & $\rightarrow$ & - & - & - & - & \multirow{8}{*}{ Gege functioned after unload } \\
\hline & & G-30 & 600 & $\equiv 600$ & -8.5 & 0.0 & -3.5 & - & - & - & $56 *$ & \\
\hline & & $c-17$ & 1200 & 1200 & -7.5 & +10.5 & +1.0 & yes & - & $\cdot$ & - & \\
\hline & & $B-42$ & 1200 & 2400 & -12.0 & +11.0 & -1.0 & yes & - & $\cdot$ & - & \\
\hline & & $c-11$ & $240:$ & 600 & -7.5 & $\div 7.2$ & -0.3 & yes & - & - & - & \\
\hline & & $F-30$ & $240 c$ & 2400 & -9.5 & D. 0 & -9.5 & - & - & $\cdot$ & - & \\
\hline & & $D-C_{4}$ & 3600 & 1200 & -10.5 & -0.8 & -11.3 & - & - & $140 *$ & - & \\
\hline & & $D-4]$ & 3600 & 3600 & -10.0 & -1.2 & - \pm 1.2 & - & - & - & - & \\
\hline \multirow{11}{*}{. } & \multirow{5}{*}{ As-Cast } & $C-12$ & 120.3 & 1200 & -1.0 & $+3 . c$ & +2.0 & yes & yes & - & 25: & \multirow{5}{*}{$\begin{array}{l}\text { Radial pressure reduced to zero-oil leak } \\
\text { Fadial gage displaced }\end{array}$} \\
\hline & & $D-2$ & 1200 & $2400(0)$ & -2.0 & \# & $* *$ & yes & yes & - & - & \\
\hline & & $E-18$ & 2400 & $60 \mathrm{C}$ & -4.0 & 0.0 & -4.0 & - & - & 196 & 28") & \\
\hline & & G-G & $24 \cdot 00$ & $240 \mathrm{C}$ & 0.0 & -2.5 & -2.5 & yes & yes & - & - & \\
\hline & & $F-20$ & $36 C 0$ & 3600 & -3.5 & $*$ th & **t & - & - & 21 & $252 *$ & \\
\hline & \multirow{6}{*}{ Alr-Dried } & $c-i 6$ & 1200 & $1200(0)$ & -7.5 & +4.5 & -3.0 & - & - & - & - & \multirow{6}{*}{$\begin{array}{l}\text { Radial pressure -educed to zero-oil leak } \\
\text { Radial pressure =educed to zero }\end{array}$} \\
\hline & & $D-+1$ & 1230 & $2403(0)$ & $-\$ 0.5$ & -6.2 & -16.7 & - & yes & - & - & \\
\hline & & $\varepsilon-4$ & 2430 & 500 & -8.0 & . & $\#$ & - & - & - & $2: 2$ & \\
\hline & & $G=19$ & 2400 & 2400 & -3.5 & $\div 1.5$ & -2.0 & - & - & - & - & \\
\hline & & $(F-6)$ & $3: 00$ & $36 \mathrm{CO}$ & -9.8 & +10.5 & +0.8 & yes & yes & - & $1+0$ & \\
\hline & & $I \cdot 30$ & 3E & 3600 & -9.2 & $* * *$ & $*$ & $\mathrm{~N} s$ & $\mathrm{NA}$ & $28 *$ & $4 *$ & \\
\hline
\end{tabular}


The axial stresses transmitted to the specimens were significantly less than those indicated by the pressure gage, due to friction losses in the hydraulic-mechanical pressure system (Refs 8 and 9). A number of attempted modifications failed to increase the efficiency of the ram (Ref 10). Therefore, each of the loading rigs was calibrated with a load cell. The efficiencies of the various units ranged from 90 to 97 percent.

The second problem involved the radial pressure system. Extreme care was required during sealing of the creep specimens. If a weak point developed in the seal, the pressurized hydraulic oil would break through the sealing jacket and penetrate the specimen, causing either structural failure or contamination of the specimen. The weakest point was usually at the interface of the end cap and the concrete. Extreme care in sealing and construction of an expansion bellows in the copper jacket at this interface partially alleviated this problem.

\section{$\underline{\text { Hydraulic System }}$}

Hydraulic pressure was provided to the loading units by the laboratory air supply system of approximately $85 \mathrm{psi}$, coupled with oil pressure intensifiers. This system was adequate for creep testing since only a very small quantity of oil was necessary once the system was pressurized. The hydraulic system consisted of a pressure control console and eight pressure manifolds to the loading units, plus return lines.

The pressure system was designed for 5000 psi maximum pressure. A dual system was employed for each of the four test pressures $(600,1200,2400$, and $3600 \mathrm{psi}$ ). One manifold system supplied pressure to the $75^{\circ} \mathrm{F}$ 1aboratory and the other to the $150^{\circ} \mathrm{F}$ temperature control room. Each manifold system contained a return line which was connected to each test unit and allowed oil to circulate to remove air from the hydraulic system and to keep valve passages clear.

The hydraulic system was designed with two back-up sybsystems. An auxiliary pressure intensiffer was installed to replace any of the four intensifiers which might fail or require maintenance. Also included was an auxiliary air compressor which would turn on automatically should the laboratory air pressure system fail.

The control system automatically regulated the pressure to within \pm 5 percent. Any combination of the eight pressure lines could be independently 
controlled and each test unit and specimen had separate shut-off controls. One significant improvement in the hydraulic pressure system would be the addition of individual pressure controls for each test unit which would allow compensation for frictional losses.

The hydraulir system, being a closed system, was subject to a total loss of pressure should any line, fitting, or specimen fail. In view of this possibility, a warning device was installed to sound an alarm if a 10 percent drop in pressure occurred. The success of this warning system was, however, entire1y dependent on an operator being present in the vicinity to close the neressary valves. In the inficlal lests thcre wore failures in fitlings and during the test program a few specimens failed. In all cases the warning system was adequate. Nevertheless, in future tests automatic shut-off valves should probably be installed in appropriate locations.

Another potentlal problem is the possibile loss of electrical power since there was no auxiliary means of maintaining the oil pressure. For a short period of time the valves on each loading unit could be closed and the pressure maintained, providing that a substantial amount of creep deformation was not occurring at the time. During the period of test, no such power failures occurred.

\section{Environmental Control}

A constant temperature and a fairly constant relative humidity had to be maintalned for an extended period of time. 'lhe tests performed at the nominal $75^{\circ} \mathrm{F}$ test condition were conducted in an air-conditioned laboratory, while the tests performed at the nominal $150^{\circ} \mathrm{F}$ test condition were conducted in a controlled temperature chamber with approximate dimensions of $14 \times 20 \times 7$ feet, which was designed to maintain a constant temperature in the range from $-20^{\circ} \mathrm{F}$ to $150^{\circ} \mathrm{F}$.

Temperatures during the test perlod were monicored and recorded both in the free air surrounding the specimens and within each specimen by means of the vibrating wire strain gages. Air-temperature measurements indicated small fluctuations for short periods of time, with the average temperature being slightly less than the desired temperatures of $75^{\circ}$ and $150^{\circ} \mathrm{F}$. Within the $150^{\circ} \mathrm{F}$.chamber fans provided the required air circulation. Temperature measurements for each specimen (Appendices $F$ and $G$ of Ref 11 ) indicated that the specimens were not subjected to large temperature fluctuations even 
though the air temperature did fluctuate for short periods of time.

The relative humidity fluctuated from about 40 to 59 percent and averaged 48 percent. This fluctuation was significant only during the curing period for the air-dried specimens since the as-cast specimens were sealed shortly after casting and all specimens were sealed during the loading period.

\section{Instrumentation}

A major problem at the time this study was initiated was finding a strain measuring device that would maintain its stability and sensitivity over a long time period and which was small enough to be cast in a $6 \times 16$-inch specimen. For many years, the stability and sensitivity requirements were satisfied only by a demountable fulcrum-plate type mechanical gage such as the Whittemore gage. This gage is impractical for measuring strains in sealed specimens that were triaxially loaded at elevated temperatures.

Vibrating Wire Strain Gage. Aftèr various commercial gages were evaluated, the PC 641, manufactured in England by Perivale Control Company, was selected. This gage is a vibrating wire device which indicates strain, or a change in strain, by a detectable change in its frequency of vibration. Actual strain is determined through calculations using the following combination of Mersonnes' and Hooke's Laws (Ref 11 ):

$$
\Delta \varepsilon=\varepsilon_{i}-\varepsilon_{f}=K\left(F_{i}^{2}-F_{f}^{2}\right)
$$

where

$$
\begin{aligned}
& \mathrm{K}=\text { gage factor, } \\
& \mathrm{F}_{i}=\text { the initial, or reference, frequency, } \\
& \mathrm{F}_{\mathrm{t}}=\text { the frequency at the strain point desired, } \\
& \varepsilon_{i}=\text { the initial, or reference, strain, } \\
& \varepsilon_{f}=\text { the strain point desired. }
\end{aligned}
$$

The Perivale gage when cast in concrete has a gage factor of $1.24 \times 10^{-3}$, which was determined experimental1y by the manufacturer. The range of the gage is approximately 285 microunits in tension to 1050 microunits in com- 
pression and although it is possible to read to one microunit of strain, such accuracy was not assumed. In future studies, the initial frequencies of these gages should be set according to the magnitude of the strain anticipated since in many cases the range of the gage was exceeded.

A cross section of the Perivale gage is shown in Fig 52. The gage is 4 inches long with a 3.44-inch gage length. Essentially the gage consists of an electromagnetic system, centrally located, a hollow brass tube with steel caps afixed to each end, and a fine, high carbon steel wire pre-tensioned between the two steel end caps. In use the gage responds to compressive or tensile forces along its principal axis, thereby decreasing or increasing the tension in the wire.

Prior to use, 50 gages were tested (Ref 6) by submerging them in water for a period of approximately 12 days. Half of the gages were in water at $75^{\circ} \mathrm{F}$ and half in water at $150^{\circ} \mathrm{F}$. Eight of the gages failed to operate after. this test, thereby indicating possible moisture leakage. These gages were allowed to air-dry in the laboratory for approximately 55 days, at which time five of the gages began to operate again. 'Twenty additional gages were waterproofed with two coats of liquid neoprene (GW-5, Budd Instrument Company) at the junction of the electrical leads and the gage house and submerged in water at $75^{\circ} \mathrm{F}$ or $150^{\circ} \mathrm{F}$. Since none of these gages failed to operate satisfactorily, all gages were waterproofed prior to use.

Temperatures within the creep and shrinkage specimens were measured throughout the test period by a Wheatstone bridge system in the sonic comparator, which measured the change in resistance of the electromagnetic coil in each gage. A coil-resistance versus temperature curve was provided by the strain gage manufacturer.

The internal temperature readings obtained from the vibrating wire strain gages were not totally reliable in terms of exact temperatures. Some differences were recorded between specimens in supposedly identical environments. Nevertheless, these measurements did provide a measure of the relative temperature changes within the specimens. To obtain more accurate and dependable temperature readings from individual specimens, thermocouples, bondable temperature sensors, or other gages should be investigated for possible use.

Gage Performance. The vibrating wire strain gages performed satisfactoril: and appeared to remain stable throughout the 20 to 71 months of the tests. 


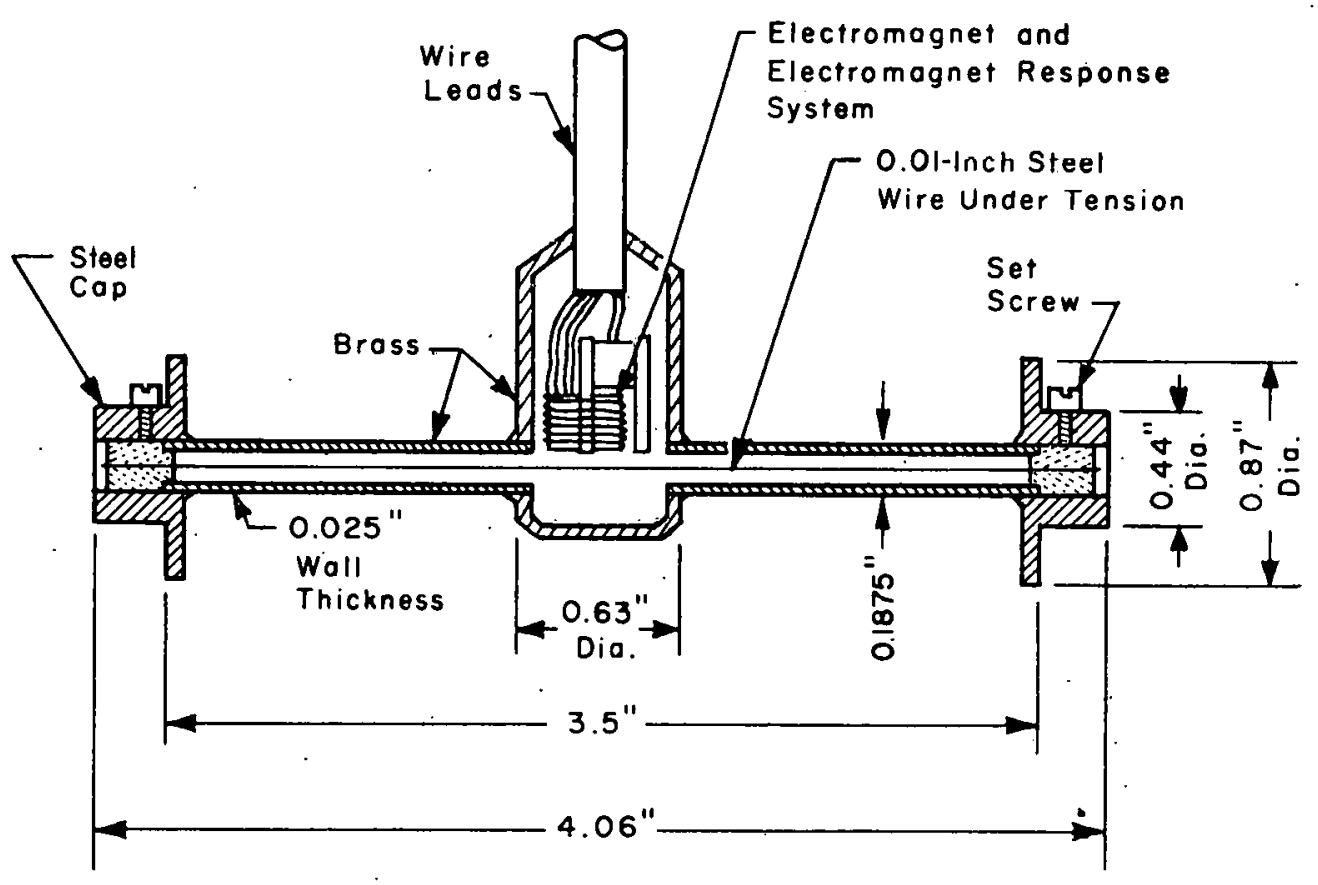

Fig 52. Cross section of Perivale vibrating wire strain gage PC 641 . 
Summaries of gage performances are contained in Tables 22 and 23 . Of the 188 gages in specimens which did not fail, 147 (78.1 percent) functioned throughout the test period, including 15 gages which functioned for approximately 6 years. of the 41 gages which became inoperative before the end of the test, 15 (7.9 percent) failed because the range of the gage was exceeded and 26 (13.8 percent) ceased to function possibly due to water or oil leakage. If the gages whose strain range was exceeded are eliminated, 162 (86.1 percent) of the gages functioned satisfactorily.

With regard to the 26 gages which ceased to function, 24 were in the $150^{\circ} \mathrm{F}^{\circ}$ test temperature and 18 of the 26 were 1 as accasi speclumis. Thus, the fail ure ratio was much more severe at the elevated temperature and in specimens with high moisture contents.

The gages whose strain range was exceeded were primarily concentrated in the biaxially and trlaxially loaded air-dried specimens, particularily at $150^{\circ} \mathrm{F}$ (Tảble 23).

The gages discussed in Chapter 3 were not thermally compatible with the concrete. Large apparent shrinkage strains, rather than expansions, were monitored for the $150^{\circ} \mathrm{F}$ test specimens between 83 and 90 days after casting (Fig 7, p 26), when the temperature environment was changed from $75^{\circ} \mathrm{F}$ ro $150^{\circ} \mathrm{F}$. This apparent shrinkage, which averaged approximately 145 microunits for the as-cast specimens and approximately 50 for the air-dried specimens, was attributed to the fact that the gage was not thermally compatible with the concrete. Therefore, this behavior is a characteristic of the gage-concrete system, rather than of the concrete alone. The gage-concrete system consists of three matertals, the concrete, the brass gage housing, and the pretensioned steel wire in the gage, each with different thermal expansion characteristics, as shown in Fig 53.

To determine the effect of temperature on the gage measurements, several tests were conducted with the gage suspended in air and unconstrained. The results revealed that rising temperatures caused the measured tension in the steel wire to increase relative to the gage housing; the gage housing expanded 4.12 microunits per degree Fahrenheit more than the wire. This is shown in Fig 53 as the 310 microunit strain difference experienced by increasing the gage temperature from $75^{\circ} \mathrm{F}$ to $150^{\circ} \mathrm{F}$. 
TABLE 22. SUMNARY OF GAGE PERFORMANCE

\begin{tabular}{|c|c|c|c|c|c|c|c|c|c|c|c|c|c|c|c|c|c|c|c|c|c|c|c|}
\hline \multirow{3}{*}{$\begin{array}{l}\text { Gage } \\
\text { Type }\end{array}$} & \multirow{3}{*}{$\begin{array}{l}\text { Curing } \\
\text { History }\end{array}$} & \multirow{3}{*}{$\underset{c}{T \in m p}}$, & \multicolumn{12}{|c|}{ Specimen and Failure Type } & & \multirow{2}{*}{\multicolumn{3}{|c|}{ Totals }} & & & \\
\hline & & & \multicolumn{3}{|c|}{ Shrinkage } & \multicolumn{3}{|c|}{ Uniaxial } & \multicolumn{3}{|c|}{ Biaxial } & \multicolumn{3}{|c|}{ Triaxial } & & & & & & & & & \\
\hline & & & $\mathrm{N}$ & $\mathbf{F}$ & $\%$ & $\mathrm{~N}$ & $\mathbf{F}$ & $\%$ & $\mathrm{~N}$ & $\mathbf{F}$ & $\%$ & $\mathrm{~N}$ & $\mathrm{~F}$ & $i$ & $\mathrm{~N}$ & F & $\%$ & $\mathrm{~N}$ & $\mathbf{F}$ & $\%$ & $\mathrm{~N}$ & $\mathbf{F}$ & $\%$ \\
\hline \multirow{5}{*}{ Axial } & & .5 & 9 & 1 & 11.1 & 6 & 0 & $a$ & 2 & 0 & 0 & 8 & 0 & 0 & 25 & 1 & 4 & \multirow{2}{*}{46} & \multirow{2}{*}{11} & \multirow{2}{*}{23.9} & \multirow{5}{*}{$94^{\circ}$} & \multirow{5}{*}{17} & \multirow{5}{*}{$\therefore 8.1$} \\
\hline & & 150 & 8 & 2 & 25 & 4 & 2 & 50 & 4 & 4 & 100 & 5 & 2 & 40 & 21 & 10 & 47.6 & & & & & & \\
\hline & \multirow{3}{*}{ Air-Dried } & & & 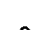 & & & & $\mathrm{c}^{-1}$ & & & & & & & & & $\therefore$ & \multirow{3}{*}{48} & \multirow{3}{*}{6} & \multirow{3}{*}{12.5} & & & \\
\hline & & .5 & 12 & 0 & 0 & 6 & 0 & a. & 2 & 0 & 0 & 8 & 1 & 12.5 & 28 & 1 & 3.5 & & & & & & \\
\hline & & 150 & 8 & 1 & 12.5 & 4 & 1 & 25 & 2 & 2 & 100 & 6 & 1 & $1 \epsilon .6$ & 20 & 5 & 25 & & & & & & \\
\hline \multirow{5}{*}{ Radial } & \multirow{2}{*}{ As-Cast } & 75 & 9 & 0 & 0 & 6 & 0 & $c$ & 2 & 0 & 0 & 8 & 0 & c. & 25 & 0 & 0 & \multirow{2}{*}{46} & \multirow{2}{*}{12} & \multirow{2}{*}{26.1} & \multirow{5}{*}{94} & & \\
\hline & & 15.0 & 8 & 5 & 62.5 & 4 & 2 & 50 & 4 & 2 & 50 & 5 & 3 & 60 & 21 & 12 & 57.1 & & & & & & \\
\hline & & -5 & & , & 0 & & & & & & & & & & & & & & & & & & 25.5 \\
\hline & Air-Dried & 15 & 12 & 1 & 8.3 & 6 & 0 & C & 2 & 1 & 50 & 8 & 1 & 12.5 & 28 & 3 & 10.1 & 48 & 12 & 25 & & & \\
\hline & ADT-DTLEO & $1 \leq 0$ & 8 & 2 & 25 & 4 & 2 & 50 & 2 & 2 & 100 & 6 & 3 & 50 & 20 & 9 & 45 & & 16 & 23 & & & \\
\hline Tota 1 & & & 74 & 12 & 16.2 & 40 & 7 & 17.5 & 20 & 11 & 55 & 54 & 11 & 20.3 & 188 & 41 & 21.8 & & & & & & \\
\hline & & & $N=$ & Jumb & r of $g$ & es. & & & & & & & & & & & & $A i r-D$ & tried & & 96 & 18 & 18.8 \\
\hline & & & $\mathbf{F}=$ & Jumb & $=$ of $\mathrm{g}$ & $e f_{a}$ & lur & & & & & & & & & & & $\mathrm{As}-\mathrm{Ca}$ & ast & & 92 & 23 & 25 \\
\hline & & & & & & & & & & & & & & & & & & $150^{\circ} \mathrm{F}$ & & & 82 & 36 & 43.9 \\
\hline & & & & & & & & & & & & & & & & & & $75^{\circ} \mathrm{r}$ & & & 106 & 5 & 4.7 \\
\hline
\end{tabular}


TKBLE 23. SUMMARY OF CAUSE OF GAGE FAILURE

\begin{tabular}{|c|c|c|c|c|c|c|c|c|c|c|c|c|c|c|c|c|c|c|c|c|c|c|c|}
\hline \multirow{3}{*}{$\begin{array}{l}\text { Gage } \\
\text { Type }\end{array}$} & \multirow{3}{*}{$\begin{array}{l}\text { Curing } \\
\text { History }\end{array}$} & \multirow{3}{*}{$\stackrel{\circ}{\circ} \mathrm{T} p,^{\text {Temp }}$} & \multicolumn{12}{|c|}{ SFecimen and Failure Typz } & & & & & & & & & \\
\hline & & & \multicolumn{3}{|c|}{ Shrinkage } & \multicolumn{3}{|c|}{ Uniaxial } & \multicolumn{3}{|c|}{ Biaxial } & \multicolumn{3}{|c|}{ Triaxial } & \multicolumn{9}{|c|}{ Totals } \\
\hline & & & $\mathrm{F}$ & 3 & 0 & $F$ & $\mathrm{R}$ & 0 & $\mathrm{~F}$ & $\mathrm{R}$ & 0 & $z$ & $\mathrm{R}$ & 0 & $F$ & $\mathrm{R}$ & 0 & $\mathrm{~F}$ & $\mathrm{R}$ & 0 & F & $\mathrm{R}$ & 0 \\
\hline \multirow{4}{*}{ Axial } & \multirow{2}{*}{ As-Cast } & 75 & 1 & o & 1 & 0 & 0 & D) & 0 & 0 & D & D & 0 & 0 & 1 & 0 & 1 & \multirow{2}{*}{11} & \multirow{2}{*}{3} & \multirow{2}{*}{8} & \multirow{4}{*}{17} & \multirow{4}{*}{7} & \\
\hline & & 150 & 2 & 3 & 2 & 2 & 1 & 1 & 4 & 2 & 2 & 2 & 0 & 2 & 10 . & 3 & 7 & & & & & & \\
\hline & \multirow{2}{*}{ Air-Dried } & $i 5$ & 0 & D & $\mathbf{0}$ & 0 & 0 & 0 & 0 & 0 & 0 & 1 & 1 & 0 & 1 & 1 & 0 & \multirow{2}{*}{6} & \multirow{2}{*}{4} & \multirow{2}{*}{2} & & & \\
\hline & & 150 & 1 & 0 & 1 & 1 & $1 \cdot$ & 0 & 2 & 1 & 1 & 1 & 1 & 0 & 5 & 3 & 2 & & & & & & \\
\hline \multirow{4}{*}{ Radia 1} & \multirow{2}{*}{ As-Cast } & 75 & 0 & 0 & o. & 0 & 0 & 0 & 0 & 0 & 0 & 0 & 0 & 0 & c & 0 & 0 & \multirow{2}{*}{12} & \multirow{2}{*}{2} & \multirow{2}{*}{10} & & \multirow{4}{*}{8} & \\
\hline & & 150 & 5 & 0 & 5 & 2 & 0 & 2 & 2 & 1 & 1 & 3 & 1 & 2 & 12 & 2 & 10 & & & & & & \\
\hline & \multirow[b]{2}{*}{ Air-Driec } & 75 & 1 & 0 & 1 & 0 & 0 & 0 & 1 & 1 & 0 & 1 & 1 & 0 & $=$ & 2 & 1 & \multirow[b]{2}{*}{12} & \multirow[b]{2}{*}{6} & \multirow[b]{2}{*}{6} & 24 & & 16 \\
\hline & & 150 & 2 & 0 & 2 & 2 & 1 & 1 & 2 & 1 & 1 & 3 & 2 & 1 & a & 4 & 5 & & & & & & \\
\hline Tota 1 & & & 12 & 0 & 12 & 7 & 3 & $\angle$ & 11 & 5 & 5 & 11 & 6 & 5 & 41 & 15 & 2.6 & & & & & & \\
\hline & . & & $F=$ & umbe & of & $\mathrm{fa}$ & ure & & & & & & & & & & & Air- & bried & & 18 & 10 & 8 \\
\hline & & & $\mathrm{R}=$ & umbs & of & $s$ o & ch & xcee & ra & & & & & & & & & $\mathrm{As}-\mathrm{C}=$ & st & & 23 & 5 & 18 \\
\hline & & & $0=$ & umbe & cf & & ch & ease & oper: & ing. & & & & & & & & $150^{\circ}$ & & & 36 & 12 & 24 \\
\hline
\end{tabular}




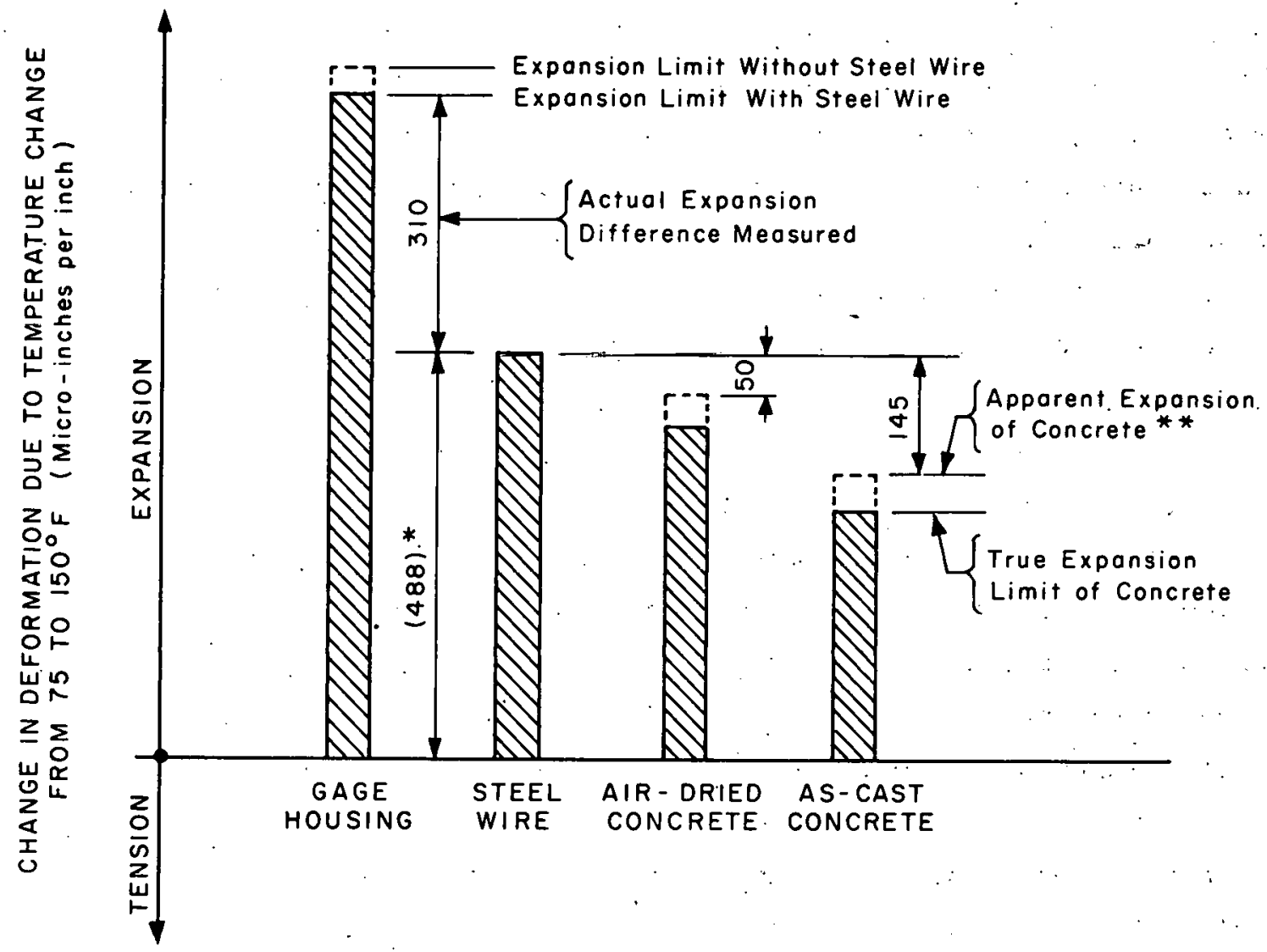

* Coefficient of thermal expansion of the steel wire is assumed to 6.5 microunits/inch $/{ }^{\circ} \mathrm{F}$; therefore, a $75^{\circ}$ increase in temperature causes a change in strain of

$$
\Delta \epsilon_{w}=(6.5) \cdot(75)=488 \text { microinches } / \text { inch }
$$

** Apparent expansion of concrete at interface with gage due to the greater expansion characteristics of gage housing.

Fig 53. Expansion characteristics of gage-concrete system. 
When the gage was encased in concrete, deformation of the gage housing was restricted by the concrete, and the pretensioned steel wire acted as though only its ends were fixed in the concrete. Consequently, if a rise in temperature caused apparent shrinkage in the concrete, the steel wire must have expanded more than the concrete, producing reduced tension in the wire and causing the gage to register compressive strains or apparent shrinkage. This means that the coefficient of thermal expansion of the concrete was less than that of the steel wire since the concrete actually expanded. Moreover, since the thermal expansion of the gage assembly was greater than that of the rnnrrete, stresses developed at the gage-concrele lulenlace, thcrcby sifghtly increasing the deformation of the concrete relative to the gage. These apparent additional strains are indicated in Fig 53 by the dotted Ines aluve the truc expansion limits of the concrete.

The apparent coefficient of thermal expansion of the materials can be calculated from the recorded strain relationships if the thermal coefficient of one of the materials is known. Assuming the coefficient of thermal expansion of the steel wire to be 6.5 microunits per degree Fahrenheit, the apparent coefficients of thermal expanston for the air-dried and as-cast concretes were $5.8 \times 10^{-6}$ and $4.6 \times 10^{-6}$, respectively. The true thermal coefficients of the concretes were probably slightly less than the apparent thermal coefficients calculated, due to the stress concentration caused by the gage. In any event, the thermal coefficient for the air-dried concrete was larger than for the as-cast concrete, which is compatible with previously reported values discussed in $\operatorname{Ref} 11$.

Subsequent to the initiation of this study, gage manufacturers have developed new gages wh1ch suppusedly are morc thermally compatih1e with the concrete or which compensate for thermal effects. It is recommended that these gages be considered for future studies; however, it is felt that the gages used in this study were satisfactory and could be used in future studies providing the gages are subjected to constant temperature environments, or some means of temperature compensation is provided, and are pretensioned for anticipated strain range.

Gage P1acement

All gages were placed and held in position as shown in Fig 2, p 12, and the concrete was rodded with a quarter-inch-diameter rod during casting. 
Measurements indicated that no gage deformation occurred when this technique was used. Radiographs of the specimens after casting indicated that the gage remained in position during the casting operation. Gage placement was evaluated by dismantling the specimens after testing; only one specimen gave any indication of possible gage displacement (Table 21).

Readout System. All strain measurements obtained throughout this study utilized a sonic comparator. Because of the many gages involved, it was necessary to establish a central switchboard capable of handing all gages. Strain gages from a1.1. specimens under test were cable-connected to these switchable panels. All panel and switch positions were identified and numerically related to corresponding specimens and specimen gages. With the sonic comparator connected to these panels it was possible to select and read the gages for any particular specimen. Preliminary tests indicated that cable length did not affect the gage readings in this study.

Throughout the study, two sonic comparators were utilized for strain and temperature readings. To preclude possible instrument variation, the gages were always read using the same comparator.

Through a fixed sequence of operations, this unit energized the electromagnet, causing the tensioned wire in the gage to vibrate, measured the frequency of vibration, compared this frequency to an internal standard, and indicated in digital form the current gage frequency. The use of this frequency and some initial, or base, frequency permitted the calculation of the change in strain using Eq 4.1. For maximum accuracy, all strain readings were made at the same temperature and only after temperature equi.1ibrium had been reached.

Throughout this study, the two original comparators functioned without problems, and required only periodic battery changes. For large-scale testing, this comparator has two limitations. Manual operation was required and no printed record was produced. In view of the numerous specimens and measurements involved in a study of this type, consideration should be given to the use of automated, print-out-type instrumentation, which has the added advantage of reducing human error.

CONCRETE AND SPECIMENS

For approximately nine months before the test specimens used in this 
investigation were cast, a number of preliminary tests (Refs 6 through 10) werc conducted with the actual test equipment and materials since much of the equipment and materials used in this study was new and had been designed specifically for this project. The purpose of these preliminary tests was to evalnate the equipment and instrumentation and to establish techniques and procedures prior to the beginning of the actual test program.

In addition, numerous concrete specimens were prepared in order to develop the techniques required for mixing the concrete and casting the specimens. Compressive strength and consistency tests were also performed to insure that the design requirements for sirengll drul consiatency would be satisfip.

The single most difficult problem encountered involved sealing the specimens to prevent moisture loss and o11 pellel laliun during the curing, loaning, and recovery periods (Ret 7 ).

The weight changes during the curing and test periods for each specimen are shown in Tables $9,19,20$, and 21 , and summaries of the changes are contained in Tables 10 and 23. The average losses during the curing period for the air-dried and as-cast specimens cured for 90 days were 9.5 and 1.7 ounces, respectively (Table 10, p 28). The ranges for the individual specimens cured for 90 days were 3.5 to 14.5 ounces for the air-dried specimens and 0.0 to 4.0 ounces for the as-cast specimens excluding specimen A-9, which lost 13 uunces.

The average weight changes during the test period are shown in Table 24 . The shrinkage and uniaxially loaded specimens, which were not confined nor subjected to a radial pressure, exhibited an average weight loss varying from 0.6 to 3.0 ounces at $75^{\circ} \mathrm{F}$ and 2.5 to 11.7 ounces at $150^{\circ} \mathrm{F}$. The biaxially and triaxially loaded specimens, however, generally exhibited a weight gain due to oil penetrating the specimens. The average gains varied from zero to 3.8 nunces at $75^{\circ} \mathrm{F}$ and 0.2 to 7.0 ounces at $150^{\circ} \mathrm{F}$. The average we1ght changes for the shrinkage specimens and creep specimens loaded uniaxially for approximately 4.75 and 5.25 years after curing periods of 365 and 183 days were minimal, varying from a -1.6 to a -3.4 ounces. In the case of biaxial and triaxial specimens, it was not possible to determine the amount of moisture loss slnce a portion of the loss could have been offset by oil penetration.

Prevention of moisture loss at $150^{\circ} \mathrm{F}$ was particularly difficult and several different sealing techniques were tried. The method finally developed 
TABLE 24. SUMMARY OF AVERAGE WEIGHT CHANGES DURING THE TEST PERIOD

\begin{tabular}{|c|c|c|c|c|c|c|c|c|c|c|c|c|}
\hline \multirow{4}{*}{$\begin{array}{c}\text { Type } \\
\text { of } \\
\text { Specimen }\end{array}$} & \multicolumn{12}{|c|}{ Average Weight Change*, oz } \\
\hline & \multicolumn{8}{|c|}{17 Months** } & \multicolumn{2}{|c|}{6.0 Years ** } & \multicolumn{2}{|c|}{5.5 Years $* *$} \\
\hline & \multicolumn{4}{|c|}{ Air-Dried } & \multicolumn{4}{|c|}{ As-Cast } & \multirow{2}{*}{$\begin{array}{c}\text { Air-Dried } \\
75^{\circ} \mathrm{F}\end{array}$} & \multirow{2}{*}{$\begin{array}{l}\text { As-Cast } \\
75^{\circ} \mathrm{F}\end{array}$} & \multirow{2}{*}{$\begin{array}{c}\text { Air-Dried } \\
75^{\circ} \mathrm{F}\end{array}$} & \multirow{2}{*}{$\begin{array}{l}\text { As-Cast } \\
75^{\circ} \mathrm{F}\end{array}$} \\
\hline & 75 & $50 \mathrm{~F}$ & 150 & $0^{\circ} \mathrm{F}$ & & ${ }^{\circ} \mathrm{F}$ & 150 & $0^{\circ} \mathrm{F}$ & & & & \\
\hline Shrinkage & (6) & -1.0 & (6) & -3.0 & (3) & -0.7 & (5) & -2.7 & (1) -0.5 & $(0)$ & (1) 0.0 & $(0)$ \\
\hline Uniaxial & (1) & -1.5 & (4) & -2.5 & (2) & -0.6 & (3) & -11.7 & (2) -1.6 & (1) -0.8 & (2) -3.4 & (2) -1.4 \\
\hline Biaxial & (1) & 0.0 & (1) & 7.0 & $(0)$ & - & (1) & 1.0 & No Tests & No Tests & No Tests & No Tests \\
\hline Triaxial & (7) & 3.8 & (4) & 6.7 & (7) & 1.0 & (3) & 0.2 & No Tests & No Tests & No Tests & No Tests \\
\hline
\end{tabular}

* Numbers in parentheses are the number of specimens for which information was available.

**Curing periods of 90 days, 183 days, and 365 days, respectively. 
was found to be fairly successful during preliminary tests. Nevertheless, it was recognized prior to the start of the actual testing program that some moisture losses and oil penetration would occur. A review of the weight changes of the individual specimens (Tables 9, 19, 20, and 21) indicates that, while most specimens did not suffer large losses, in a few cases as much as 16 ounces were lost during the 15-month test period.

One major point of moisture loss for all specimens was the lead wire holes located in the loading heads, or end caps. These holes, approximately 0.2.5 inch in diameter, accommodated the cable leads from the embedled strain gages. Atthough the holes and cables were staled with cpory, they represented a potential weak point in the moisture barrier. In future creep tests, consideration should be given to using compresisiun fittings together with a sealant which is non-hydroscopic and non-temperature sensitive. These fittings could be either at the outer or inner surface of the end caps or at both locations. In addition, the lead wire holes which are to be filled with the sealant probably should be oversized to facilitate sealing with epoxy. A second problem, regarding both moisture loss and oil penetration, concerned the effectiveness of the solder joint between end caps and the copper jacket. The mass of steel made it difficult to bring the end cap to the proper soldering temperature without overheating the concrete adjacent to the end caps. Pretinning the end cap helped the soldering operation and kept the temperature at an acceptable level but did not entirely eliminate cold-solder joints. In future studies, consideration should be given to the use of a solder which has a lower melting point, but which has adequate strength, and to the possibility of redesigning the end cap to reduce its mass and provide a collar to which the copper can be soldered.

Oil penetration of radially loaded specimens was a significant problem throughout the test. Penetration often occurred at the joint between the copper jacket and end caps. During the hydraulic loading of the specimen, either the copper jacket tended to pull away from the end cap, if the solder joint was poor, or the copper would tear. To a certain extent, the latter problem was eliminated by forming a slight expansion bellows in both ends of the copper jacket.

In the post-test evaluation, it was found that in specimens where oil penetrated the joint, it would migrate down the gage lead wires, saturating the surrounding concrete, and, in some cases, entering the gage. 0il also 
penetrated a few specimens through pin holes in the copper jacket, which developed during soldering or because of improperly filled surface voids and voids just below the surface. In several instances, a very rough epoxy coating caused the jacket to be perforated under load.

Except for occasional gage failures due to malfunction or to exceeding the operating range of the gage, the shrinkage specimens and the uniaxially and triaxially loaded specimens generally performed satisfactorily. However, as illustrated in Table 20, it was essentially impossible to load the specimens biaxially. Often the specimen deformed axially to such an extent that it failed in tension during or soon after loading. In addition, cnd caps were often ejected when oil penetrated the copper at the concrete end cap interface. It is recommended that no additional effort be devoted to obtaining biaxial creep information.

EXPERIMENT DESIGN

Future experiments should utilize a statistical design which would allow the resulting data to be analyzed using accepted procedures. Such designs definitely should include duplicate specimens in order to obtain information on experimental error. 


\section{THIS PAGE}

\section{WAS INTENTIONALLY LEFT BLANK}


CHAPTER 5. CONCLUSIONS AND RECOMMENDATIONS

The conclusions, findings, and recommendations from this study have been subdivided as follows:

(1) Technical Conclusions and Findings,

(2) Conclusions and Recommendations Concerning the Experimental Program, and

(3) Recommendations for Future Studies.

TECHNICAL CONCLUSIONS AND FINDINGS

Strength

(1) After 90 or more days of curing, the unconfined compressive and indirect tensile strengths for the as-cast concrete were greater than for the air-dried concrete. Prior to 90 days, the air-dried specimens were stronger. During the 90-day curing period, concrete cured in lime-saturated water (standard ASTM curing) until tested exhibited higher compressive and tensile strengths than as-cast and air-dried specimens. The average tensile strengths increased slightly with age.

(2) The average compressive strengths of the standard cured specimens at 28 and 90 days were 6420 and 8220 psi, respectively.

(3) The strengths of the specimens were consistent within each batch of concrete and were not significantly different between batches.

\section{Instantaneous and Elastic Properties}

(1) Excluding hydrostatically-loaded specimens, the modulus of elasticity for specimens cured for 90 days ranged from $4.0 \times 10^{6}$ to $7.1 \times 10^{6}$ psi and averaged $5.5 \times 10^{6}$ psi.

(2) The alr-dried 90-day specimens had slightly lower moduli. of elasticity than the as-cast specimens, but the difference was not significant.

(3) The 90-day specimens loaded at $150^{\circ} \mathrm{F}$ had smaller moduli than the specimens loaded at $75^{\circ} \mathrm{F}$.

(4) The modulus of elasticity increased only slightly with increased curing time. 
(5) Poisson's ratio was not significantly affected by curing history, curing time, or testing temperature. Values ranged from 0.21 to 0.29 and averaged 0.25 .

Thermal and Shrinkage Characteristics

(1) The apparent thermal expansion of the air-dried concrete was larger than that of the as-cast concrete.

(2) Essentially no shrinkage occured in the as-cast specimens during the 90-day curing period.

(3) During the curing period, the 90-day air-dried specimens exhibited continuous shrinkage, with the axial shrinkuge strain exceeding the radial shrinkage strain. At the end of 82 days of curing, the average axial and radial shrinkage strains were 240 and 190 microunits.

(4) Subsequent to sealing 82 days after casting, the axial and radial shrinkage strains in the air-dried specimens began to converge, becoming essentially equal, after which no additional shrinkage occurred.

(5) During the stressed period for the 90-day specimens, the as-cast specimens at $75^{\circ} \mathrm{F}$ exhibited essentially no shrinkage. The airdried shrinkage specimens at $75^{\circ} \mathrm{F}$ exhibited an apparent shrinkage throughout the stressed period; however, the magnitude of the strains after 12 months was relatively small, with 34 microunits (tension) in the axial direction and 18 microunits (compression) in the radial direction.

Túä 3Llaills

(1) The total strain and the strain rate for air-dried specimens were significantly larger for as-cast specimens.

(2) The total strain and the strain rate for specimens at $150^{\circ} \mathrm{F}$ wcre significantly larger than for specimens at $75^{\circ} \mathrm{F}$.

(3) The order of increasing total strains was $75^{\circ} \mathrm{F}$, as-cast; $75^{\circ} \mathrm{F}$, aix-dried; $150^{\circ} \mathrm{F}$, as-cast; and $15 U^{\circ} \mathrm{r}$, air-drled.

Greep Strainc and Bchavior

(1) The creep behavior involved many interacting effects. The following factors produced a highly significant influence on the observed creep behavior and it was found that the creep strains for specimens cured for 90 days were larger for
(a) a test temperature of $150^{\circ} \mathrm{F}$ than for $75^{\circ} \mathrm{F}$,
(b) air-dried concrete than for as-cast concrete,
(c) increased time after loading, and
(d) higher uniaxial and biaxial stress levels. 
(2) The actual magnitude of the creep strain was dependent on the other factors. The following two and three-factor interactions were found to significantly affect creep behavior:

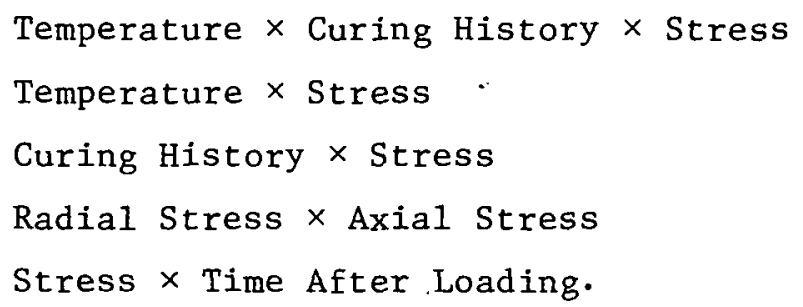

(3) The effect of curing history decreased with time. During the first 2.5 years under load, the ratios of the as-cast strains to the airdried strains were $0.80,0.86$, and 0.81 for the 90,183 , and $365-$ day specimens, respectively, with an overall average of 0.82 . During the next 2.5 years the strains appeared to be approaching the same value.

(4) The curing time prior to loading influenced the magnitude of the creep strains. Longer curing periods generally resulted in smaller creep strains. During the first year under load, the creep strains in the specimens cured for 183 or 365 days were approximately 85 and 68 percent, respectively, of the creep strains in the specimens cured for 90 days.

\section{Creep Poisson's Ratio}

(1) A creep Poisson's effect did occur and the creep Poisson's ratio ranged from approximately 39 to 84 percent of the elastic Poisson's ratio, the magnitude of which depended primarily on curing history and on. the state of stress. The average creep Poisson's ratio for the entire test period was 0.16 , which was approximately 65 percent of the average elastic Poisson's ratio.

(2) Creep Poissnn's ratin for air-dried concrete was approximately 70 percent of the value for as-cast concrete.

(3) The magnitude of stress and the state of stress influenced creep Poisson's ratio, but this influence was less at higher temperatures and for air-dried concrete.

(4) There was no evidence that creep Poisson's ratio was time dependent.

\section{Prediction of Creep Behavior}

(1) A series of regression equations were developed which estimated the creep behavior of the specimens. The multiple correlation coefficients for these equations were 0.99 .

(2) Predictive equations based on the unit creep function were developed to estimate long-term creep behavior under multiaxial states of stress frum shurt-term uniaxial creep tcote. These equations satisfactorily predicted the creep behavior of specimens subjected to multiaxial stresses and the long-term uniaxial creep behavior. 
Instantaneous Recovery

(1) Instantaneous recovery was not affected by temperature but was linearly related to the previously sustained stress for stress levels less than about 55 percent of the ultimate strength of the concrete.

(2) Instantaneous recovery strains for air-dried specimens were larger than for as-cast specimens, which is probably related to the higher strengths of the as-cast specimens.

(3) The instantaneous recovery strains at the time of unloading were generally higher than the instantaneous elastic strains at the time of loading a year earlier, especially at $75^{\circ} \mathrm{F}$.

(1) The inotantancous recovery Tuissun's lallu was nor affected by temperature nor state of stress, but was greater for the as-cast specimens than for the air-dricd specimens. Poisson's ratio for instantaneous recovery varied from 0.20 to 0.27 and averaged 0.25 , which was essentially equal to Poisson's ratio at the time of loading.

Creep Recovery

(1) Creep recovery strains were affected by temperature, curing history, and stress conditions. The creep recovery strains were larger at $150^{\circ} \mathrm{F}$ than at $75^{\circ} \mathrm{F}$ and were larger for air-dried specimens than for the as-cast specimens. The magnitude of the creep recovery strains was also related to the magnitude of the previously sustained stress.

(2) At $75^{\circ} \mathrm{F}$, the ratio of the creep recovery strains 5 months after unloading to the creep strains 12 months after loading was larger for the air-dried specimens than for the as-cast specimens; however, at $150^{\circ} \mathrm{F}$ the ratio was larger for the as-cast specimens.

(3) The creep recovery strains were smaller than the instantaneous recovery strains, in contrast to the fact that during the loading period the creep strains were larger than the instantaneous strains. At $75^{\circ} \mathrm{F}$, the ratio of creep recovery strain 5 months after unloading to the instantaneous recovery strain was larger for the air-dried specimens than for the as-cast specimens; however, at $150^{\circ} \mathrm{F}$ the ratio was larger for the as-cast specimens.

(4) Creep recovery Poisson's ratio was larger for the as-cast specimens than for the air-dried specimens. Excluding hydrostatically-loaded specimens, creep recovery Poisson's ratios 5 months after unloading varied from 0.16 to 0.28 and averaged 0.23 for the as-cast specimens.. For air-dried specimcno, the ratios varied frum 0.02 to 0.21 and averaged 0.13 . These values are similar in magnitude to the observed creep Poisson's ratio.

(5) In long-term tests there was no apparent effect on creep recovery produced by time or curing history. 
(6) The principle of superposition overestimates the actual creep recovery strains and thus should not be used unless a relatively large error can be tolerated.

\section{CONCLUSIONS AND RECOMMENDATIONS CONCERNING THE EXPERIMENTAL PROGRAM}

(1) For the most part, the equipment and procedures utilized in this study were satisfactory and it was concluded that the overall study was successful.

(2) It was extremely difficult to load specimens biaxially. Large axial strains developed quickly and the specimen either failed in tension or failed at the interface between the specimen and the end cap.

(3) The most difficult problems involved the sealing of specimens to prevent moisture loss and oil penetration.

(a) The method of sealing was generally adequate to prevent moisture loss. The one major weakness in the seal was the lead wire holes located in the loading head. Moisture loss was much more severe at $150^{\circ} \mathrm{F}$ than at $75^{\circ} \mathrm{F}$. Improved methods of sealing the lead wire holes should be investigated.

(b) $0 i 1$ penetration of specimens subjected to radial pressure was more difficult to control than moisture loss. In some cases, oil penetrated the specimen through pinholes in the copper jacket or at the specimen end cap interface. Pinholes were developed during handling or created by the high radial pressures penetrating the copper at surface irregularities. Observed failures at the end caps were caused by large axial strains and cold-solder joints between the caps and the copper jacket.

(c) Soldering of the copper jacket to the end caps was difficult. Future studies should consider using solder with a lower melting point and redesigning the end caps to reduce their mass and to provide a collar to which the copper can be soldered.

(4) The vibrating wire strain gages performed satisfactorily and appeared to remain stable throughout the test period which varied from 20 to 71 months. Approximately 78 percent of the gages functioned throughout the test, including 15 gages which functioned for approximately 6 years. Only 13.8 percent actually failed and these failures can probably be attributed to oil and water entering the gage. An additional 7.9 percent became inoperable because the range of the gage was exceeded. Eliminating those gages whose operating range was exceeded, 86.1 percent of the gages functioned satisfactorily.

(a) Gage failure was much more severe for $150^{\circ} \mathrm{F}$ and for as-cast specimens.

(b) The gages did not monitor absolute temperature accurately. If such information is needed in future studies, other gages or methods of monitoring temperature should be investigated. 
(c) The gages should be further waterproofed prior to use.

(d) The gages whose operating range was exceeded were primarily in the biaxially and triaxially loaded air-dried specimens, particularly at $150^{\circ} \mathrm{F}$. For future tests, the initial frequencies should be set in accordance with the anticipated strains.

(e) The gages were not thermally compatable with the concrete, and appropriate correlation factors should be employed for test conditions in which the temperature is varied.

(f) The method of positioning and maintaining the gages during casting was satisfactory.

(5) The loading syscem was generally safislactory. 'the on 1 y major problem was the fact that it was necessary to correct the axial stresses in friction losses. A significant improvement would be the addition of individual pressure controls for each test unit, which would allow compensation for friction losses.

(6) In hydrostatically loaded specimens, the radial strains generally were larger than the axial strains. The friction losses in the axial load, however, could not account entirely for the observed differences and the cause was attributed to the relative sizes of the gages and specimens and the configuration of the specimen and end caps. These differences were much larger for high stress levels. Future tests should consider the possible effects of specimen size, shape, and configuration.

(7) The experiment was not designed statistically. Future studies should utilize statistically-designed experiments developed in cooperation with an experienced, applied statistician.

\section{RECOMMENDATIONS FOR FUTURE STUDIES}

(1) Future studies should concentrate on uniaxial tests with minimum effort devoted to triaxial tests because of the difficulties associated with sealing and loading the specimens. If triaxial tesst.s are needed, it is resnmmended that hydrnstatic tests he conducted with the specimen subjected to oil pressure in all directions. No biaxial tests should be conducted.

(?) Tt ia not nepessary to measure radial stidills ill. Iulurt leslb sinct these strains relate primarily to Poisson's effects. Since creep and creep recovery Poisson's ratios have been established, such measurements are unnecessary.

(3) Future tests related to prestressed concrete reactor vessels should concentrate on a curing history similar to the as-cast condition used in this study.

(4) Uniaxial creep tests at temperatures in excess of $150^{\circ} \mathrm{F}$ should be conducted to establish the relationship between creep behavior and temperature. 
(5) There is a definite need to determine the load-deformation-time relationships for concrete subjected to extremely high rapid heating. This condition should simulate a localized hot spot at the inner surface of the containment vessel caused by a failure of the thermal barrier. Ideally, this condition should involve as-cast concrete which is under load.

(6) Additional work is needed to determine the load-deformation-time relationships for concrete subjected to step changes in load and temperature which simulate the load and temperature conditions developed in a reactor during construction and operations. 


\section{THIS PAGE}

\section{WAS INTENTIONALLY LEFT BLANK}




\section{REFERENCES}

1. Chuang, J. W., Thomas W. Kennedy, and E. S. Perry, "An Approach to. Estimating Long-Term Multiaxial Creep Behavior from Short-Term Uniaxial Creep Results," Uni on Carbide Report No. 2864-3, Department of Civil Engineering, The University of Texas at Austin, June 1970.

2. Hijazi, M. Amin, and Thomas W. Kennedy, "Creep Recovery of Concrete Subjected to Multiaxial Compressive Stresses and Elevated Temperatures," Union Carbide Report No. 3661-1, Department of Civil Engineer1ng, The University of Texas at Austin; June 1972.

3. Kennedy, Thomas W., and E. S. Perry, "An Experimental Approach to the Study of the Creep Behavior of Plain Concrete Subjected to Triaxial Stresses and Elevated Temperatures," Union Carbide Report No. 2864-1, Department of Civil Engineering, The University of Texas at Austin, June 1970.

4. Kennedy, Thomas W., "Long Term Creep Behavior of Concrete and the Effects of Curing," Union Carbide Report No. 3661-2, Department of Civil Engineering, The University of Texas at Austin, June 1972.

5. Kennedy, Thomas W., "Long Term Creep Behavior of Concrete," Union Carbide Report No.3899-1, Department of Civil'Engineering, The University of Texas at Austin, January 1975.

6. Kennedy, Thomas W., "Vibrating Wire Gages and Accessories," unpublished research memorandum, Union Carbide Subcontract 2864, Department of Civil Englneering, The Univcrsity of Texas at Austin, February 1968.

7. Kennedy, Thomas W., "Sealing of Specimens to Prevent Moisture Loss," unpublished resealch memorandum, Union Carhide Subcontract 2864, Department of Civil Engineering, The University of Texas at Aưstin, June $18,1.968$.

8. Kennedy, Thomas W., "Pilot Test 1," Union Carbide Subcontract 2864 , unpublished research, Department of Civil Engineering, The University of Texas at Austin, July 21, 1968.

9. Kennedy, Thomas W., "Pilot Test 2 ," Union Carbide Subcontract 2864, unpublished research, Department of Civil Engineering, The University of Texas at Austin, August 2, 1968. 
10. Kennedy, Thomas W., "Loss of Axia1 Load Due to Friction in the Loading Ram," Union Carbide Subcontract 2864, unpublished research, Department of Civil Engineering, The University of Texas at Austin, August 15, 1968.

11. York, G. P., Thomas W. Kennedy, and E. S. Perxy, "Fxperimental Invastigation of Creep in Concrete Subjected to Multiaxial Compressive Stresses at Elevated Temperatures," Union Carbide Report No. 2864-2, Department of Civil Engineering, The University of Texas at Austin, June 1970 .

12. Ncville, A. M., and B. L. Meyers, "Creep of Concrete Influencing Factors und Prediction," sympostum on lireep nf connrete, Amorican Conerete Institute, Publication SF-9, pP $1-31$. 
APPENDIX $\dot{A}$

TOTAL STRAIN RELATIONSHIPS FOR SPECIMENS CURED FOR 183 AND 365 DAYS 
THIS PAGE

\section{WAS INTENTIONALLY \\ LEFT BLANK}




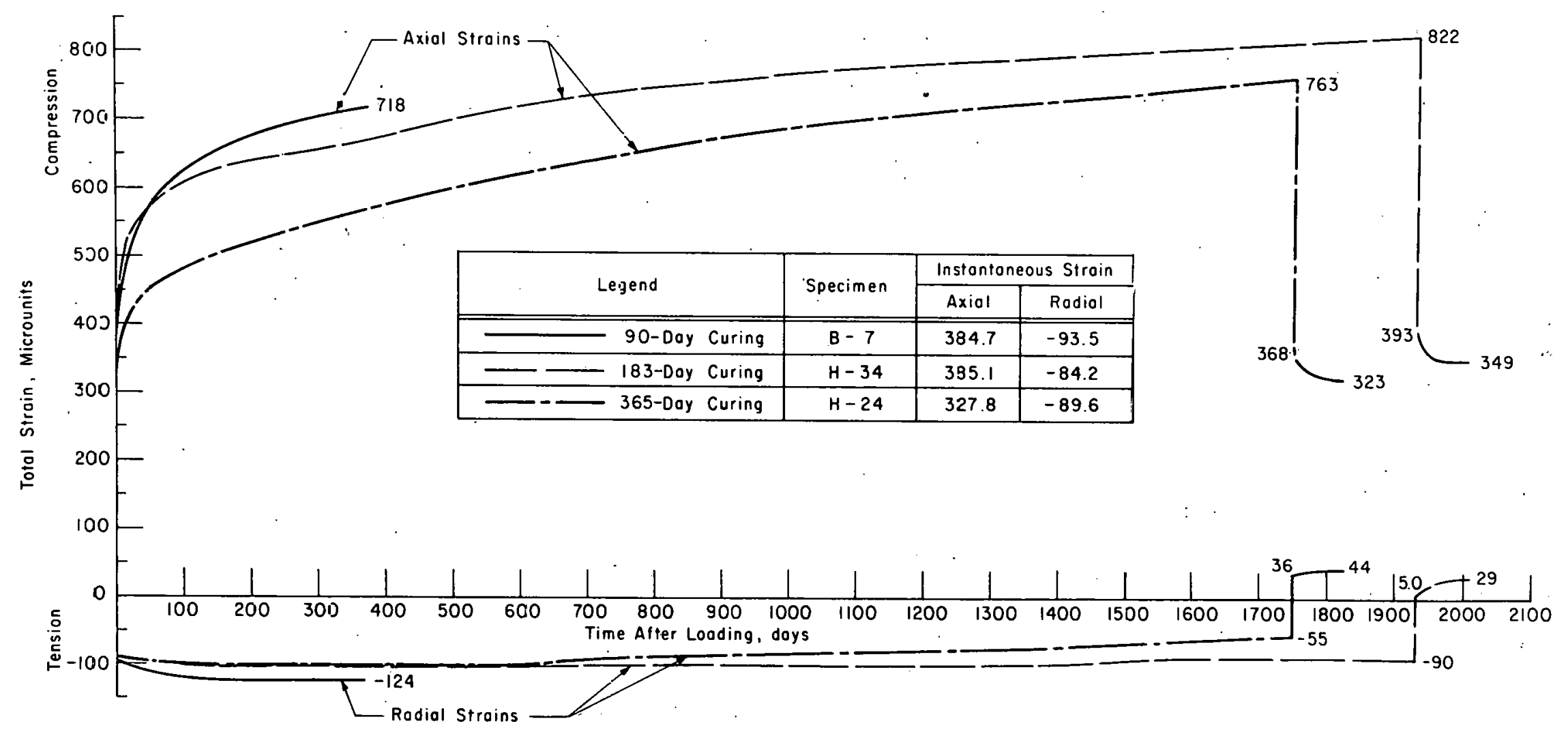

Fig A-1. Total axial and radial strain relationships for as-cast specimens with uniaxial stress of 2400 psi. 


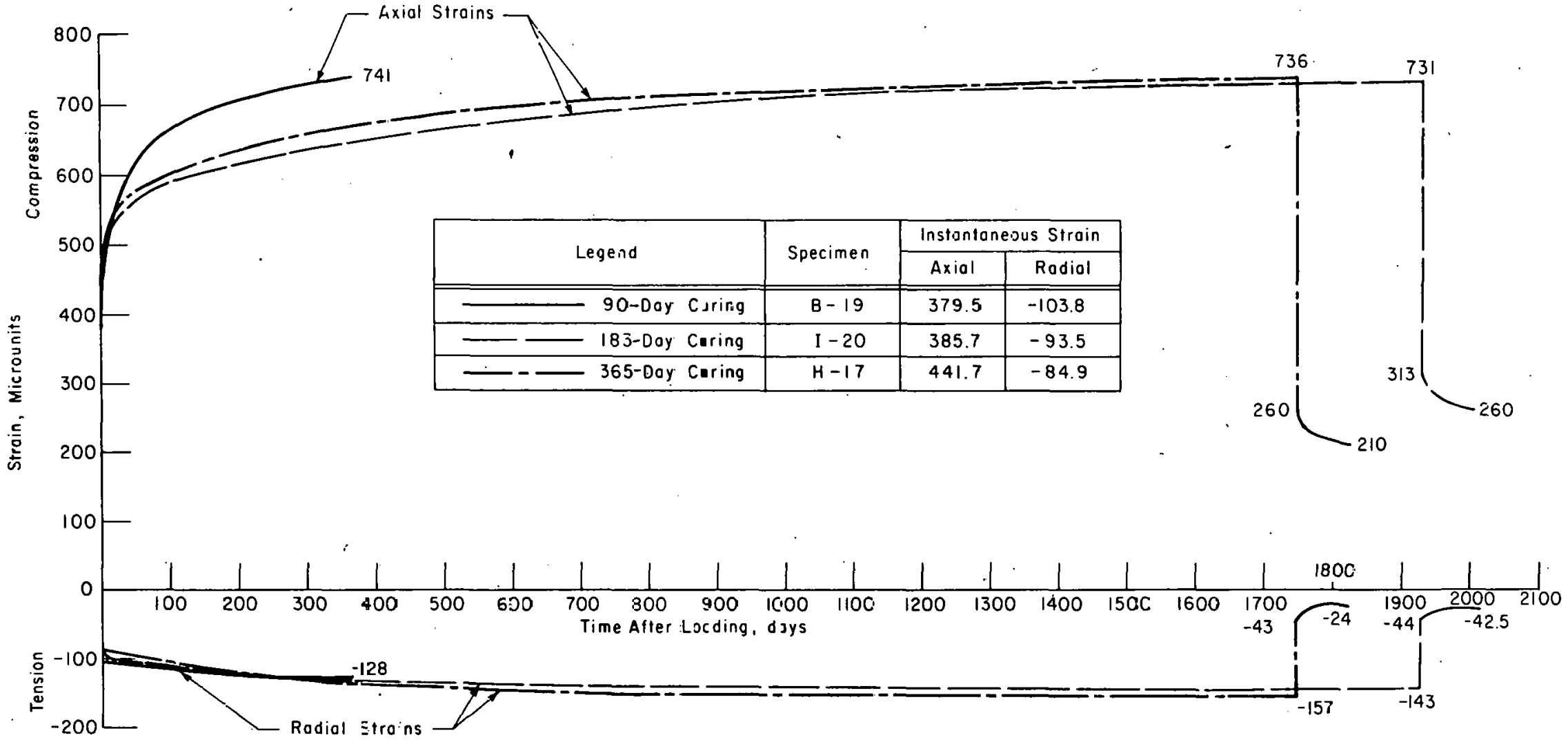

Fig A-2. Total axial and radial strain relationships for air-dried specimens with uniaxial stress of 2400 psi. 


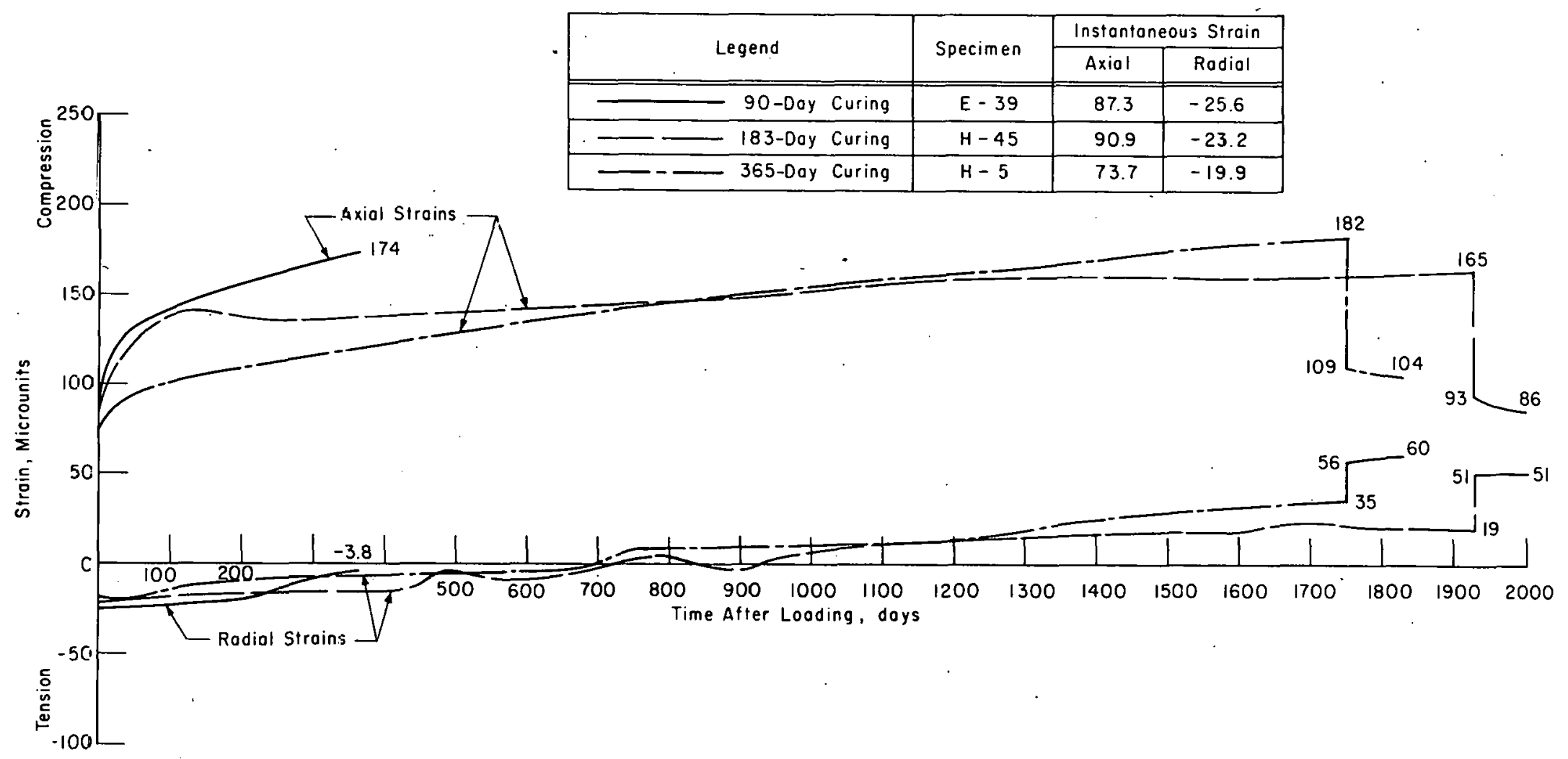

Fig A-3. Total axial and radial strain relationships for as-cast specimens with uniaxial stress of $6.00 \mathrm{psi}$ 


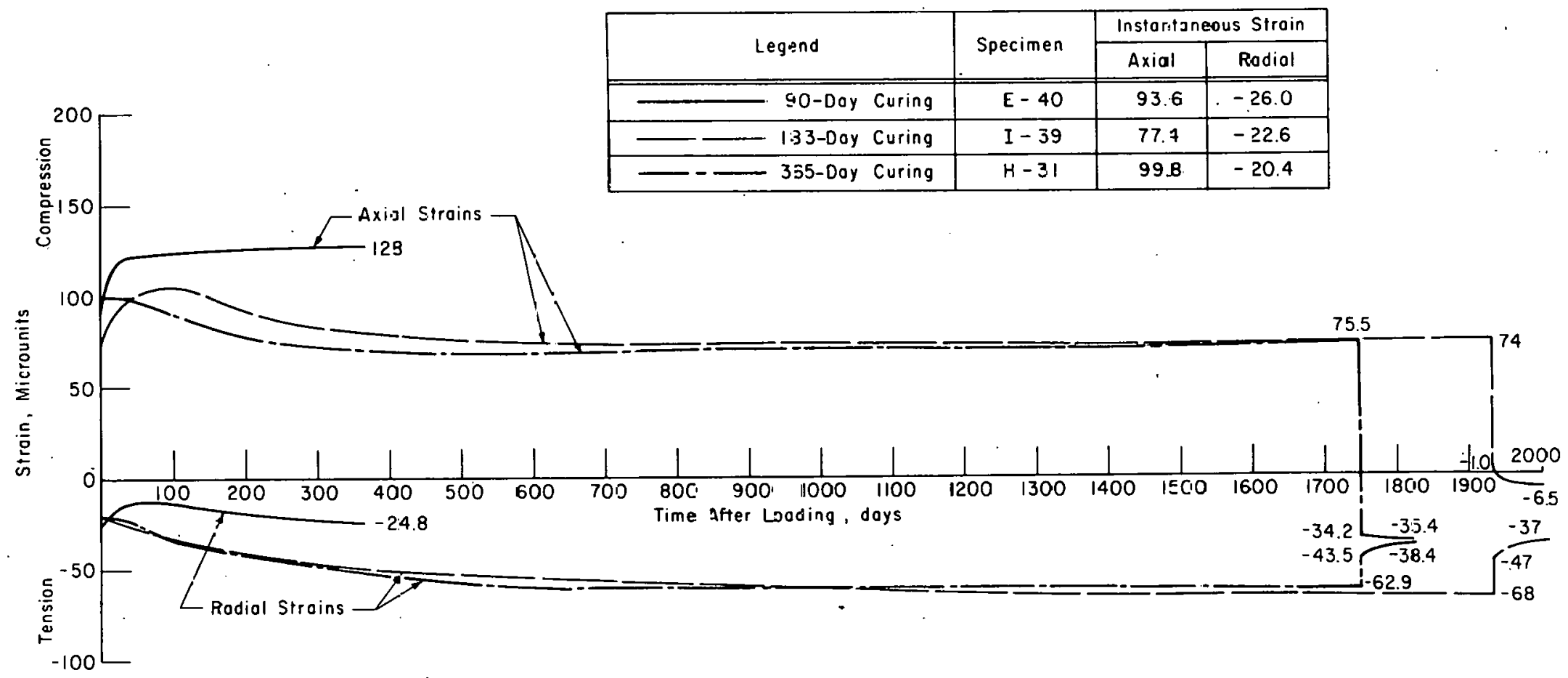

Fig A-4. Total axial and radial strain reletionstips for air-dried specimens with uniaxial stress of 600 psi. 